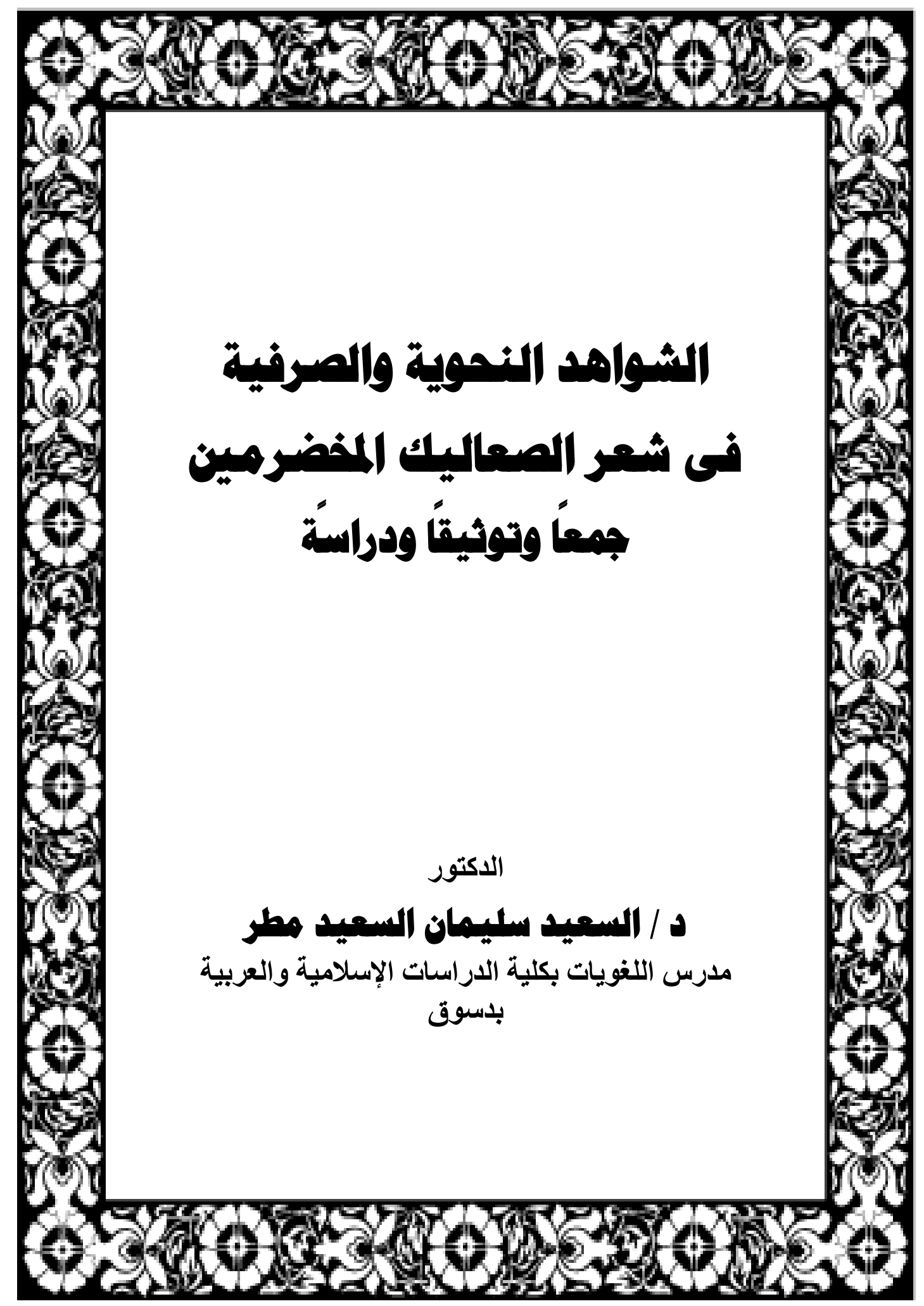




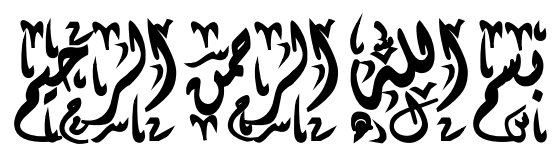

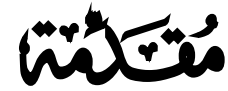

الحمد الله رب العالمين ، والصلاة و السلام على المبعوث رحمة للعـالمين

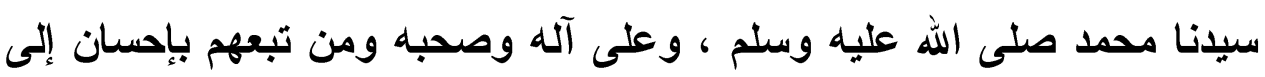

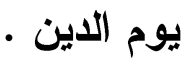

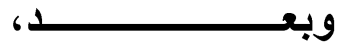

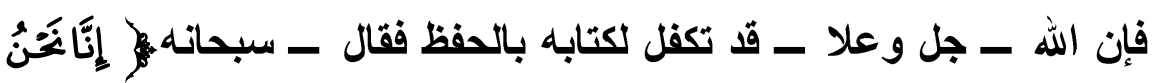

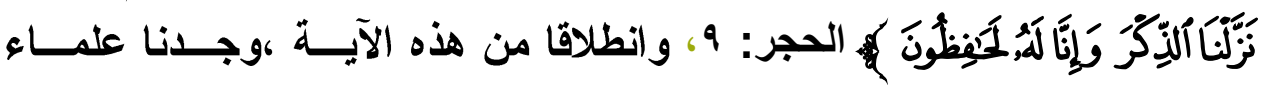

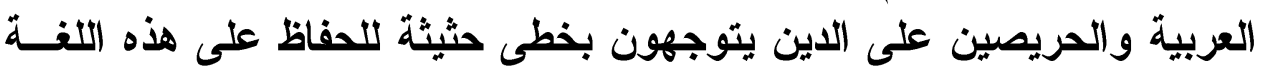

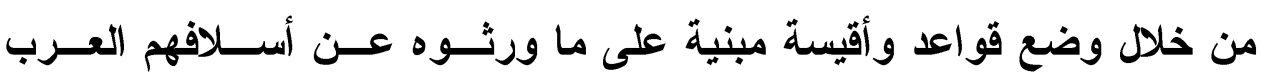
| (الفصحاء.

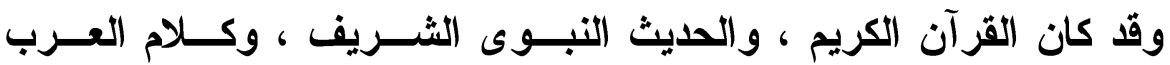

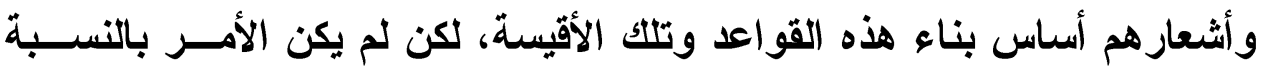

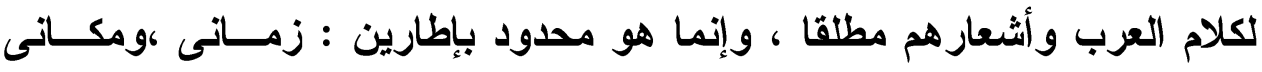

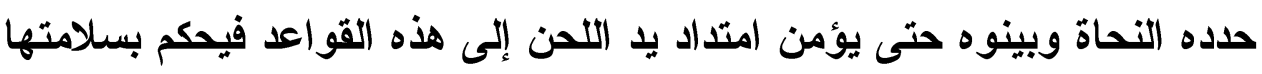
وقوة إحكامها.

أطرح هذه المقدمة لأبين مدى عناية النحاة بالثعر العربى مصدرا أصـيلا

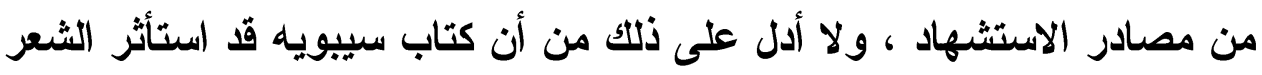
فيه بالنصيب الأوفى والقدح المعلى • ولادئ 


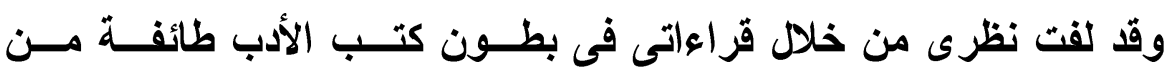

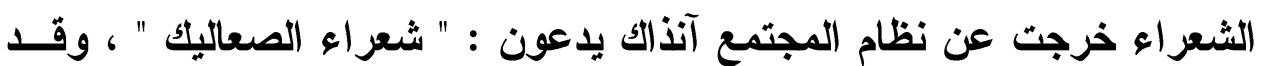

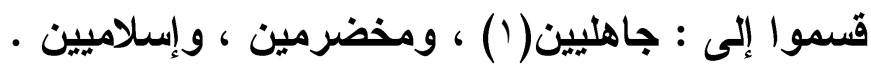

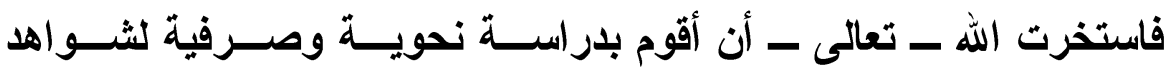

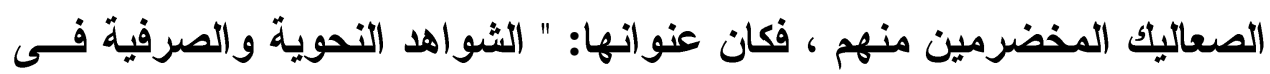

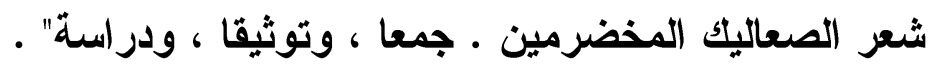

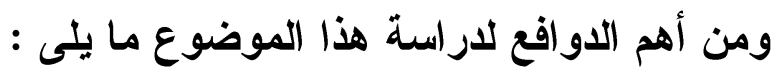

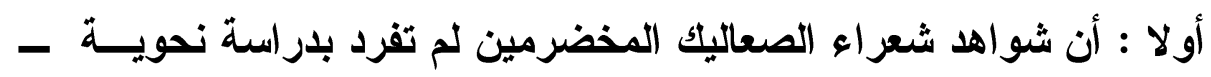

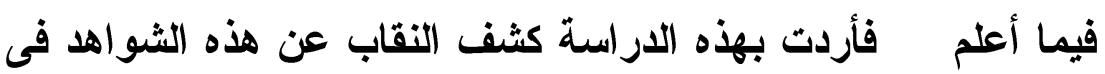
كتاب يلم شتاتها ؛ حتى يتم النفع به ، ويسهل التهل الوصول إليه اليه.

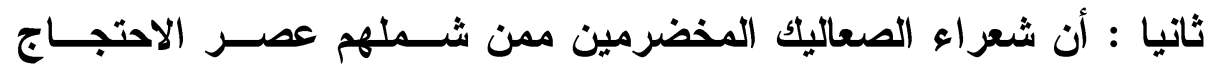

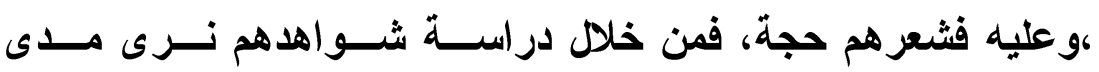
مطابقتها للقو اعد النحوية و والصرفية أو فئه مخالفتها لها. هذا ، وقد اقتضت طبيعة البحث أن يكون فى مقدمة وثلاثة فصول وخاتمة .

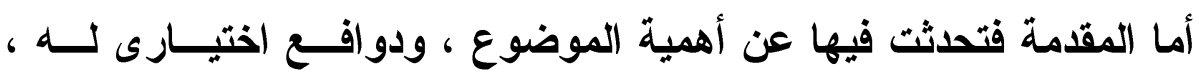

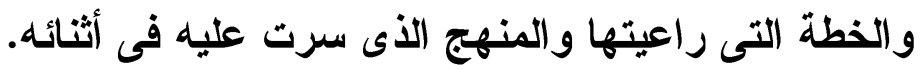

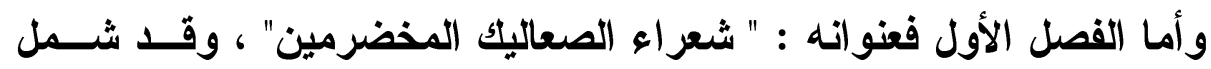

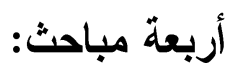

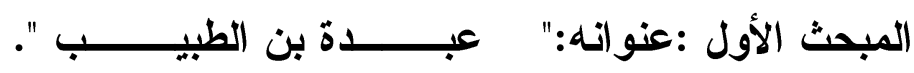

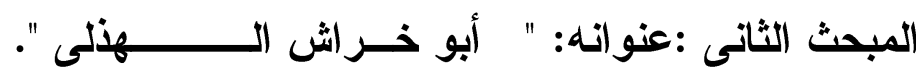

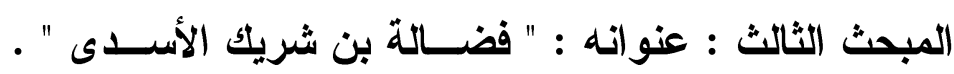

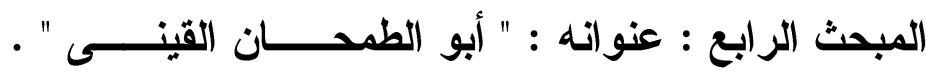

وأما الفصل الثانى فعنوانه : " الثواهد النحوية فى شعر الصعاليك المخضرمين". ') قام بدراسة شواهدهم الأخ الفاضل الدكتور / محمد عبد الستار أبو زيد في أثناء دراســـه للماجستير،وعنوان رساتته : " الأسماء العاملة عمل الفعل فى شعر الصعاليك الجاهليين". 
وأما الفصل الثالث فعنوانه : " الثواهد الصرفية فى شعر الصعاليك المخضرمين".

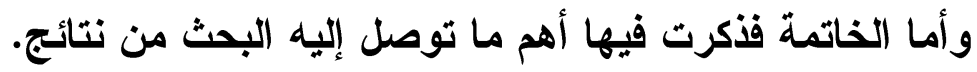

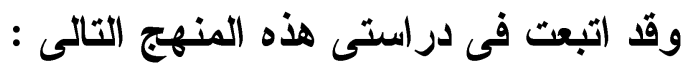

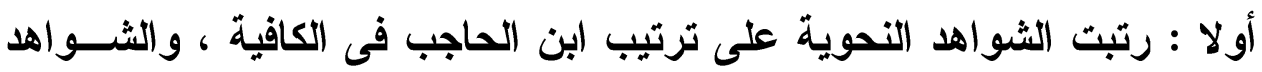

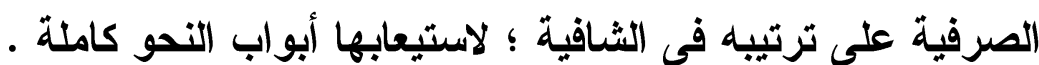

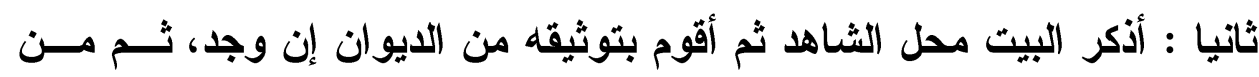
كتب الأدب واللغة و النحو و الصرف.

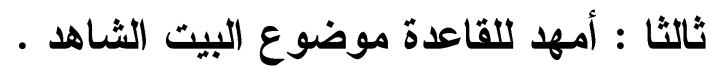

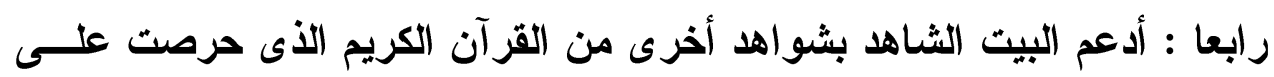

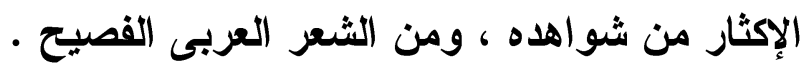

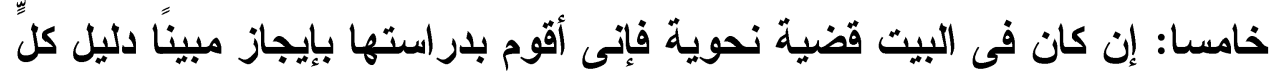
مرجحًا للمختار داعمًا إياه بالدليل.

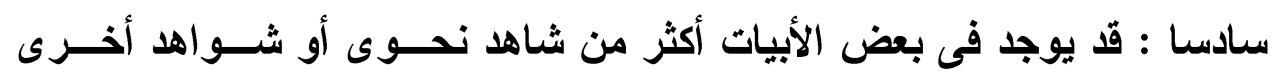

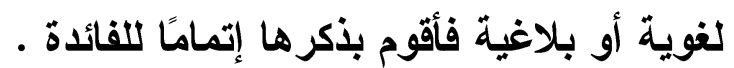

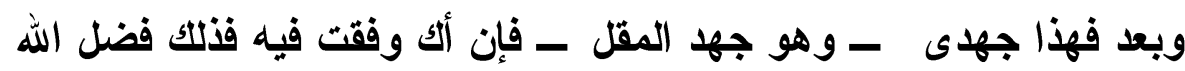

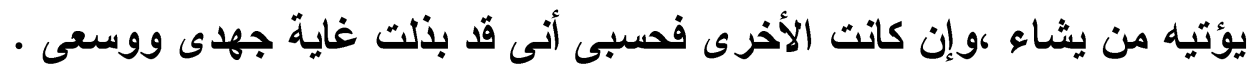

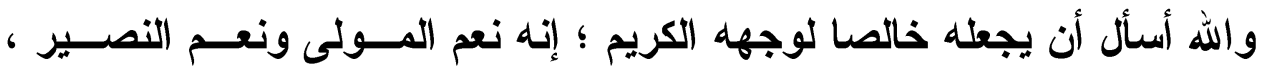
وبالإجابة جدير ، وهو حسبنا ونعم الوكيل ،

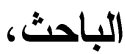


- พ074.

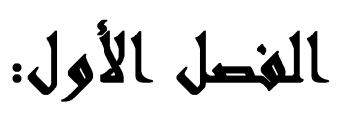

شعراء الصماليك المخضرمب.

وتحته مبامشث:

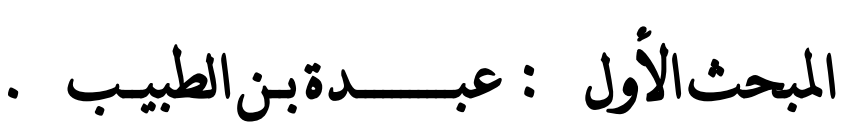

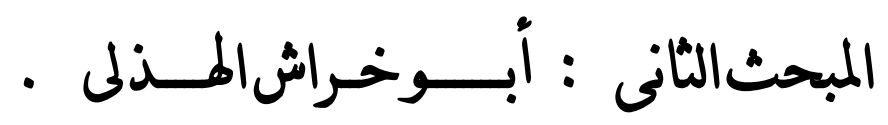

المبحث الثالث : فضالة بن شريكالأسدى .

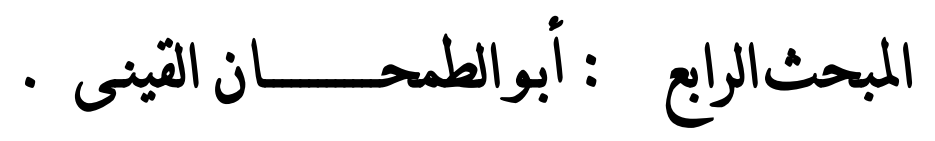




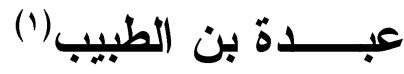

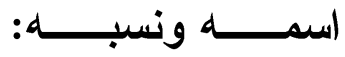

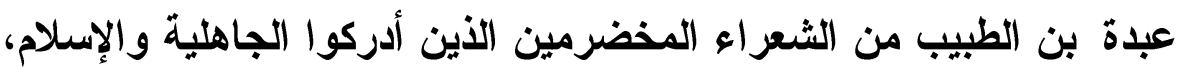

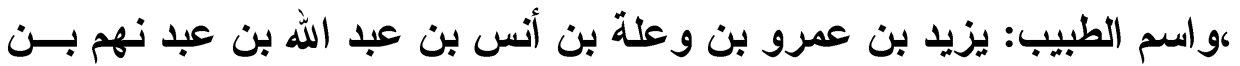

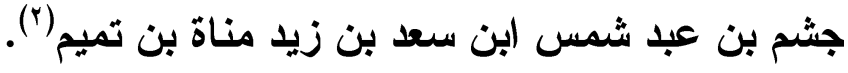

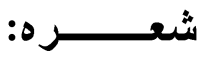

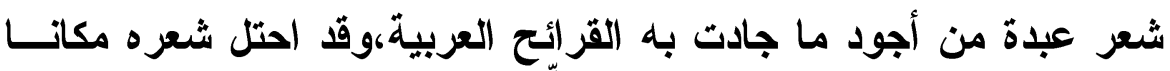

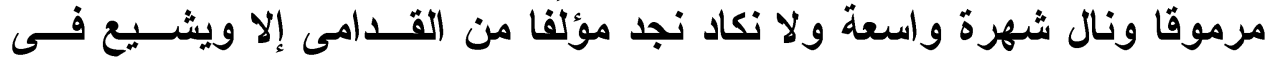

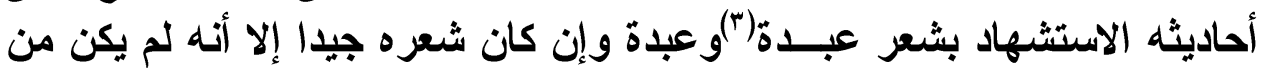

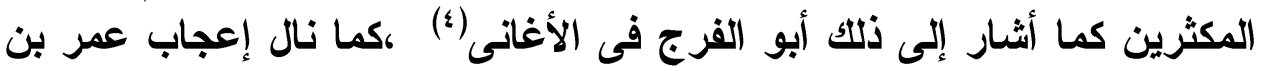

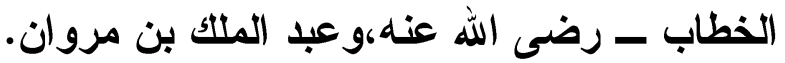

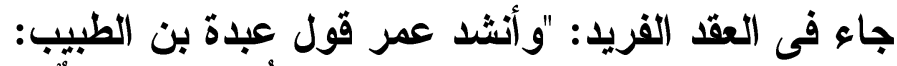

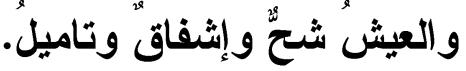

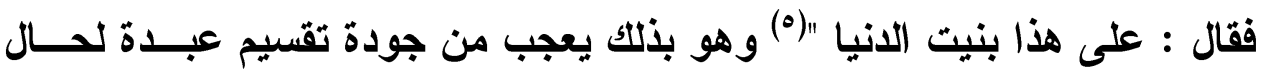

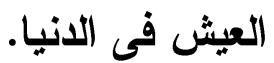

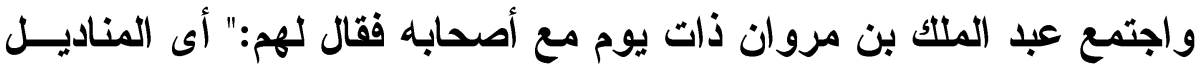

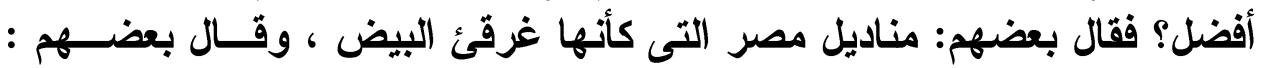

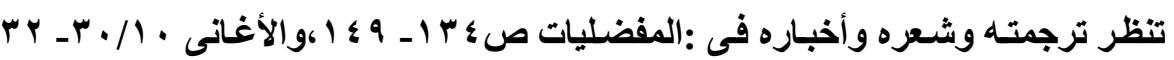

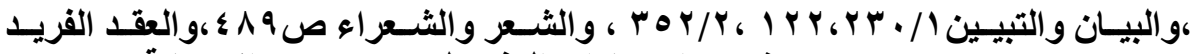

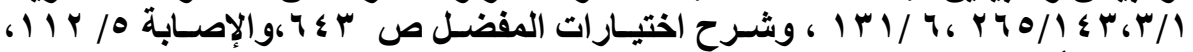

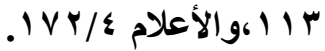

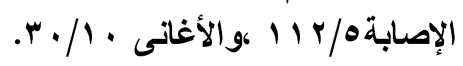

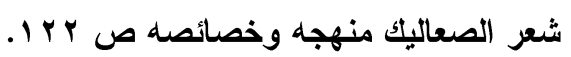

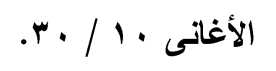

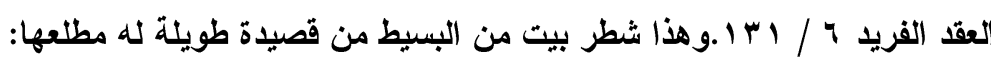

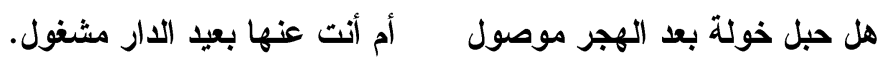

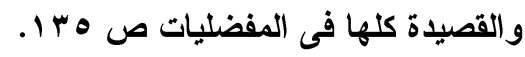


مناديل اليمن التى كأنها أنوار الربيع ، فقال: ما صنعتم شيئا. أفضــل المناديــل

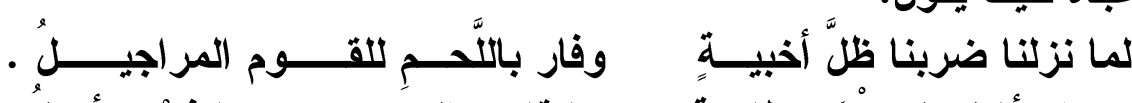

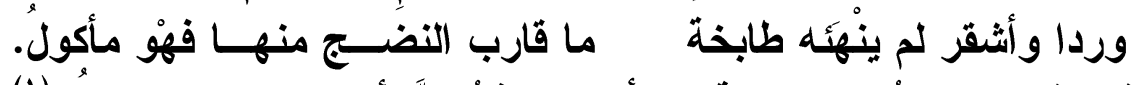

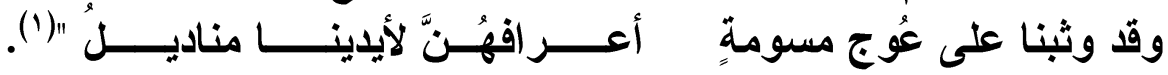

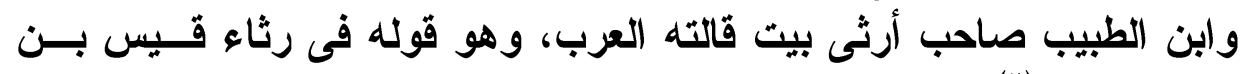

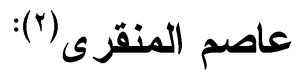

فما كان قيس هلكه هلتك واحد ولكنه بنيان قوم تهدما(").

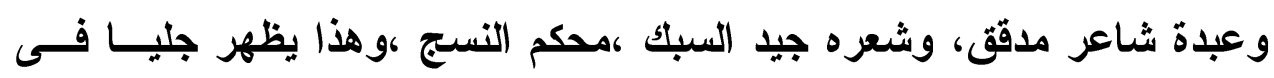

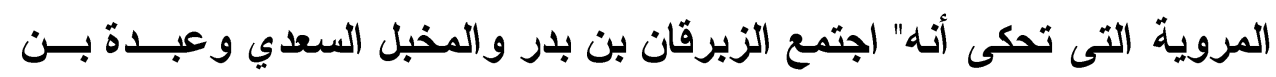

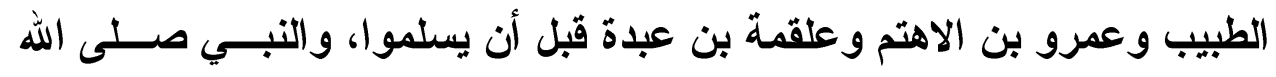

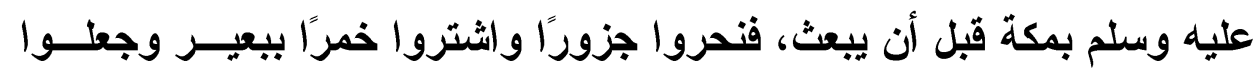

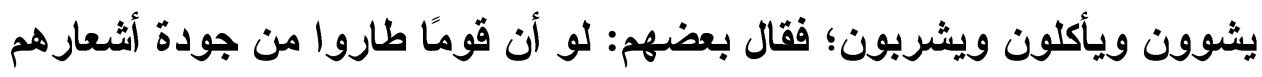

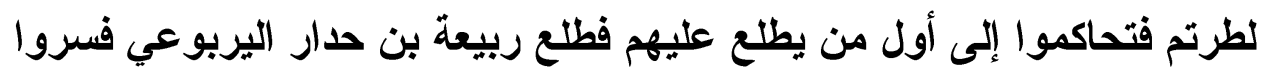

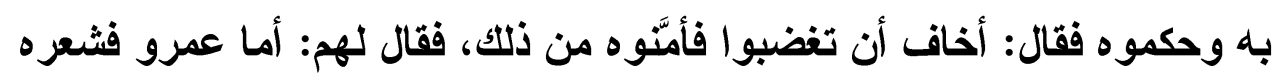

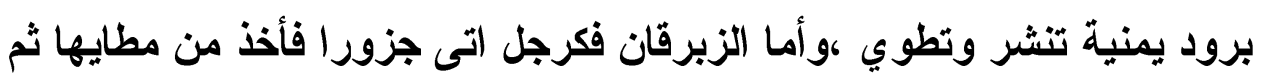

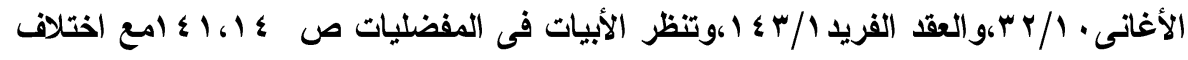

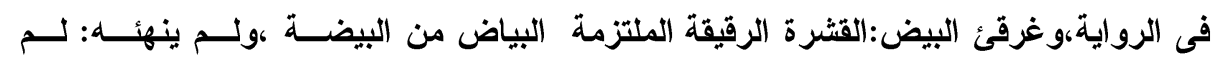

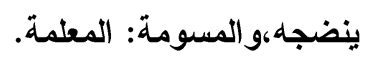

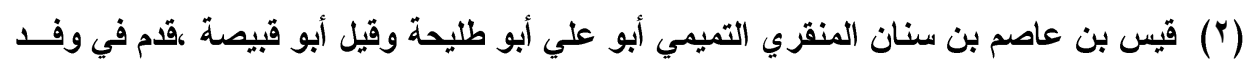

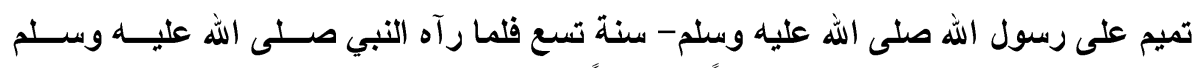

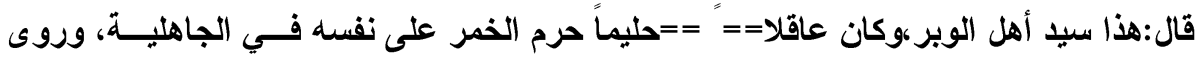

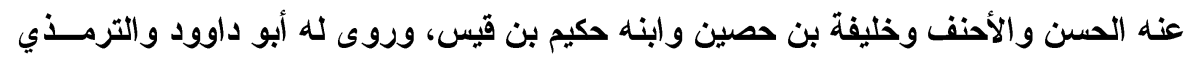

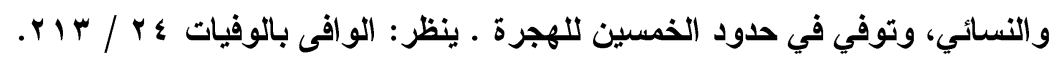

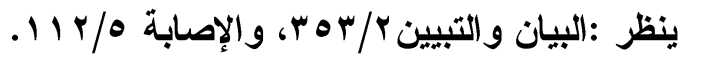


خلطه بعد ذللك، وأما المخبل فثهب نار يلقيها الله على من يشاء مسن عبــاده،

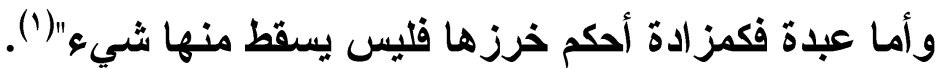

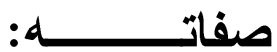

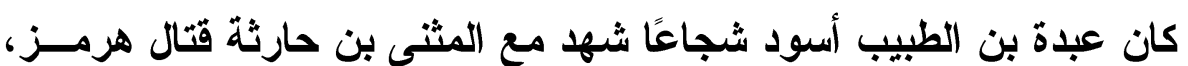

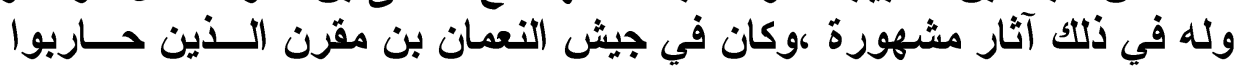

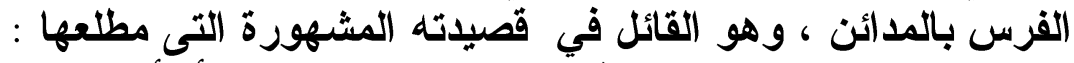

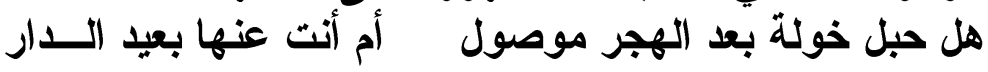

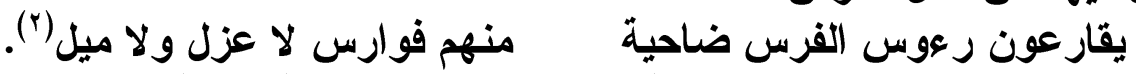

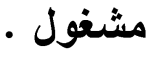
يقول فيها عن قتال الفرس :

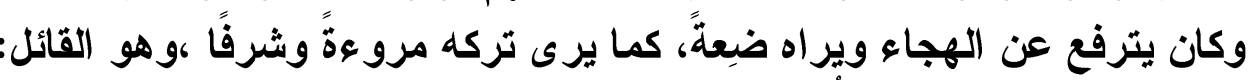

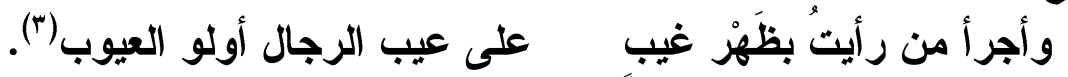

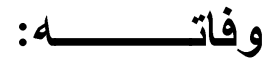

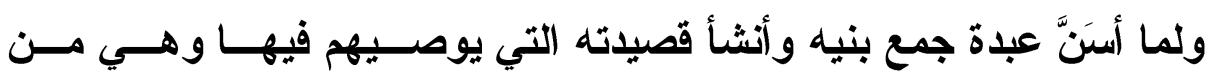

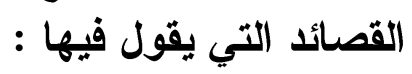

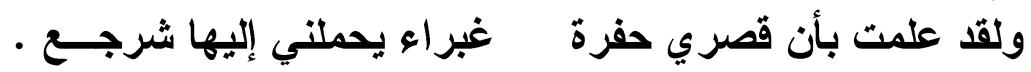

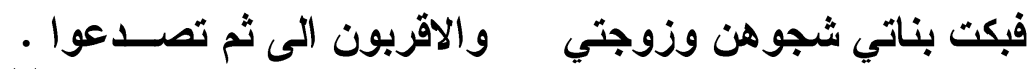

وتركت في غبراء يكره وردها

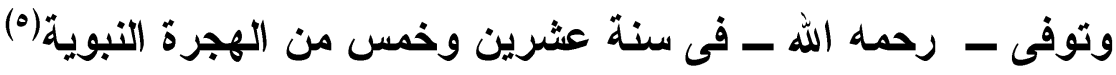

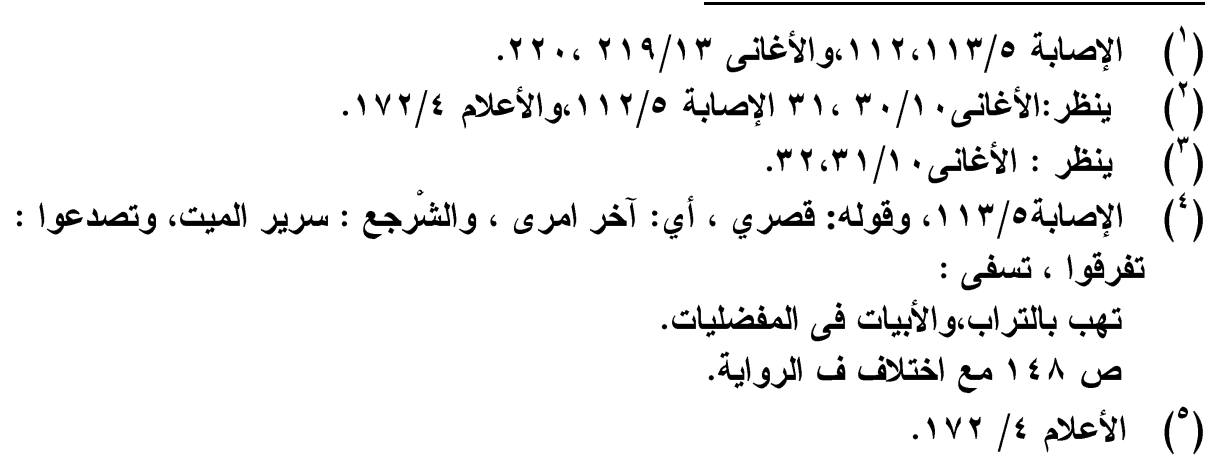




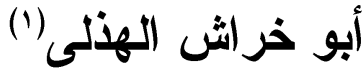

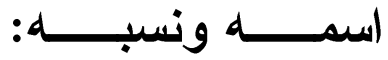

هو: خويلا بن مرة أحد بني قرد واسم قرد عمرو بن معاوية بن سعد بـن

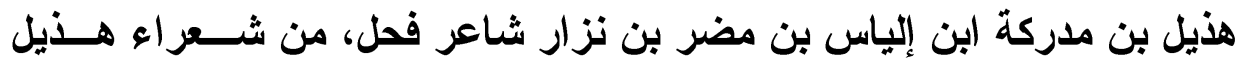

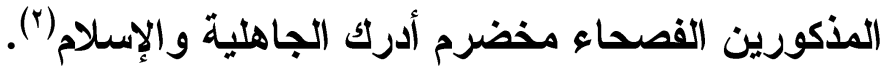

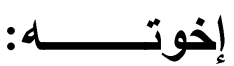

تحكى لنا كتب التراجم أنَّ لأبى خراش عشرةً من الأخوة الأكور هم: أبــو

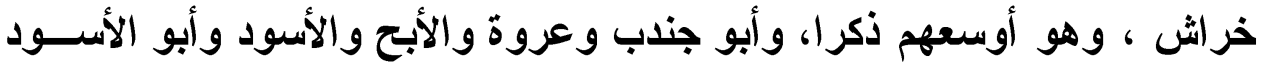

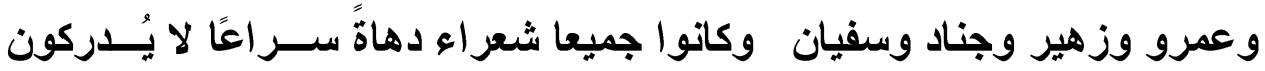

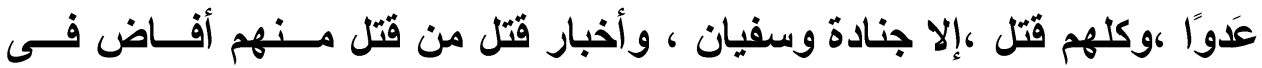
ذكرها أبو الفرج الأصفهانى ().

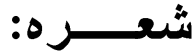

أجاد أبو خراش فى وصف الصحراء وحيوانها ،وتحدث عن سرعة عدوه ،ونجاته من خصومه ،وملحه لابية السلمى صاحب العزى التى كاتث لغطفــان

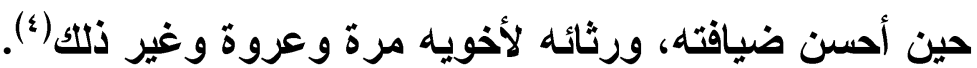
وقال محمد بن يزيد : مما يستحسن لأبي خراش الهذلّي وهو أحد حكماء العرب قوله يذكر أخاه عروة:

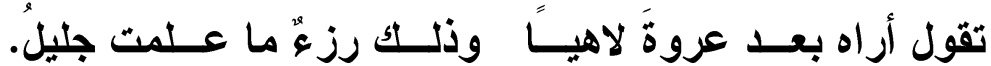

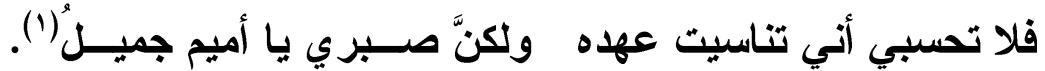

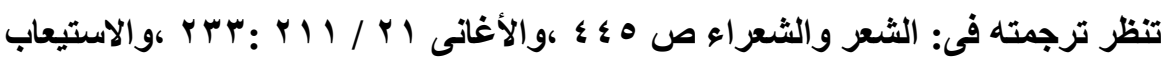

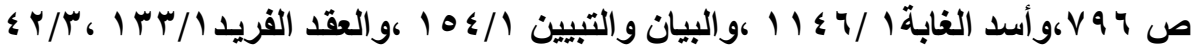

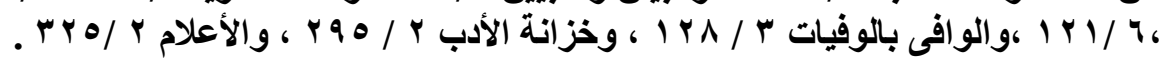

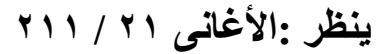

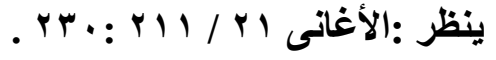

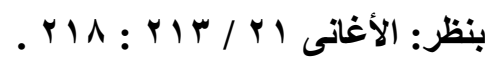




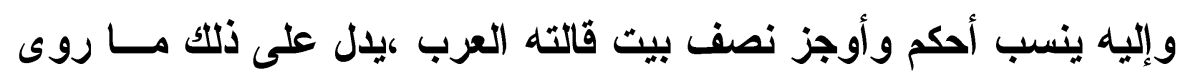

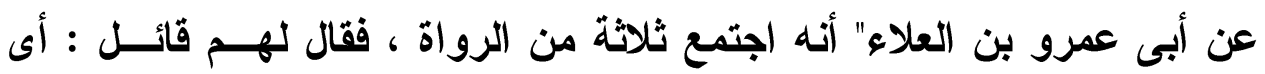

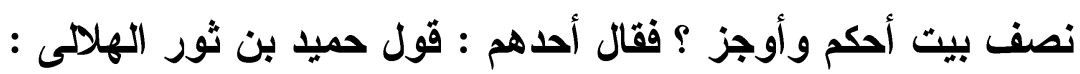

وحسبك داء أن تصح وتسلما .

وقال الثانى من الرواة الثلاثة بل قول أبى خراش اله الهذلى :

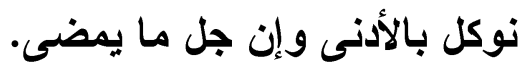

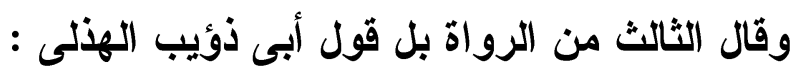

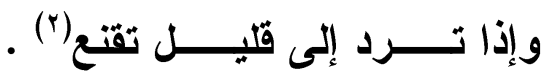

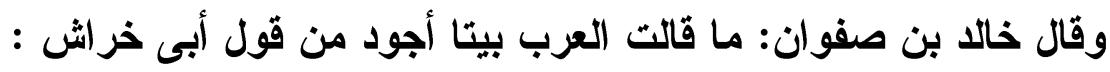

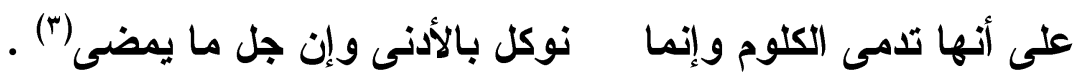

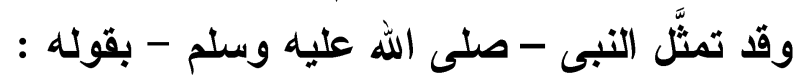

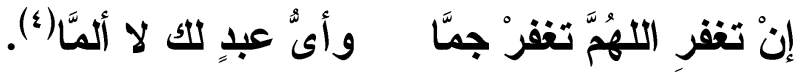

صفاتــــــه

اجتمع لأبى خر اش صفاتٌ تدل على نبله وعلو شأنه،وهى الكرم ، والزهد ، وسرعة العدو وغير ذلك من الصفات الجليلة. فمما يال على كرمه الذى أودى بحياته بعد إسلامه أنها أتاه نفر من أهل أهل

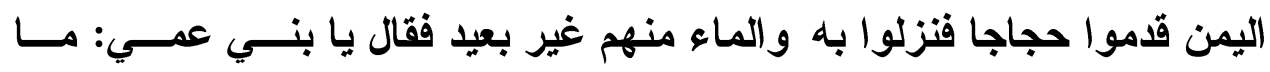

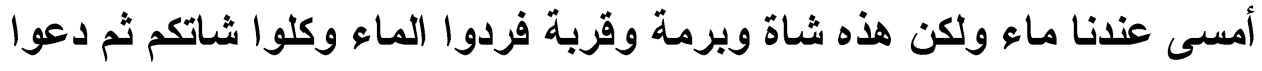

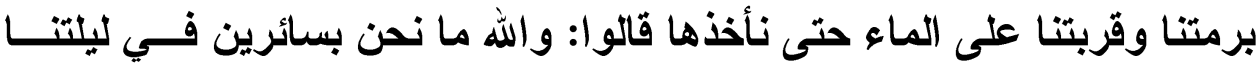

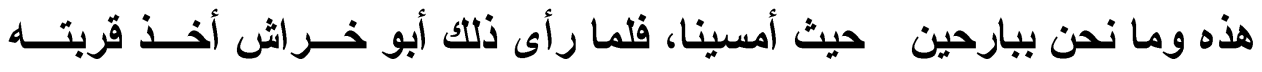

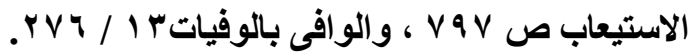

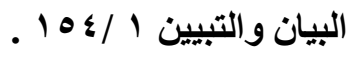

$$
\begin{aligned}
& \text { الاستيعاب ص } \\
& \text { ينظر : خزانة الأدب r / ه ץ ـ . }
\end{aligned}
$$


وسعى نحو الماء تحت الليل حتى استقى ثم أقبل صادرا فنهشته حيــة قبـــل أن أن

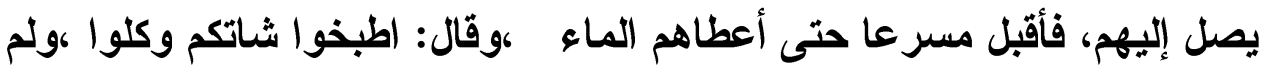

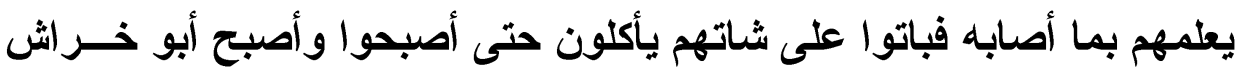

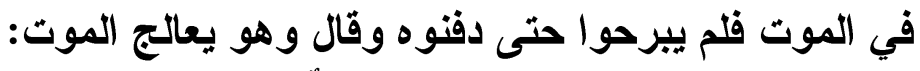

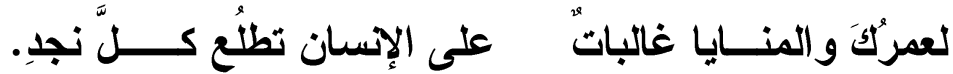

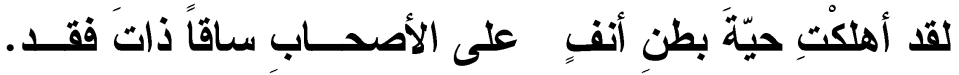

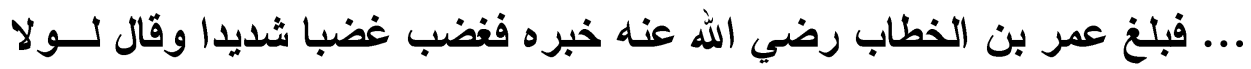

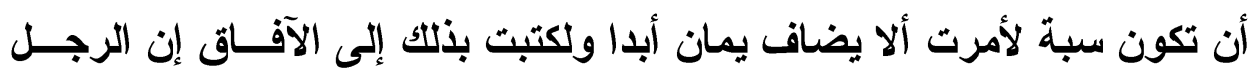

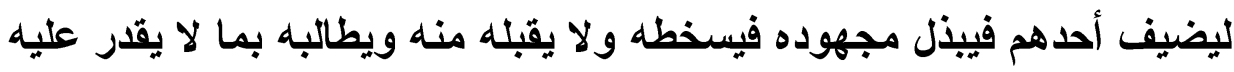

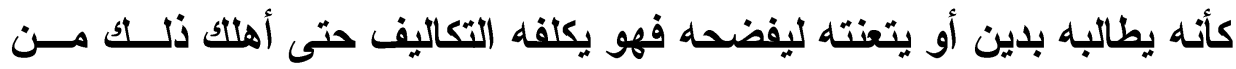

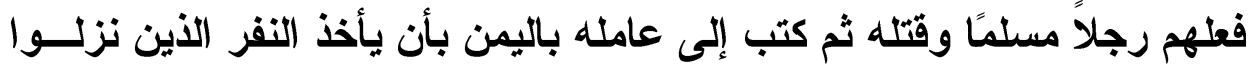

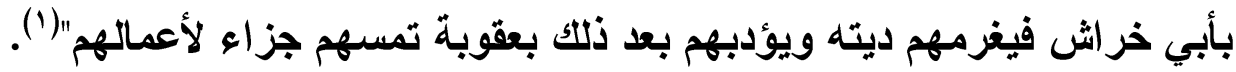

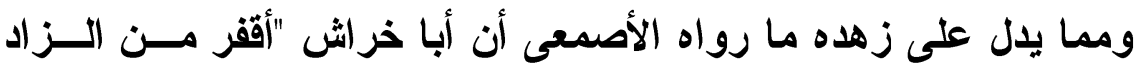

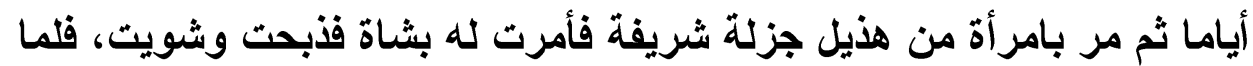

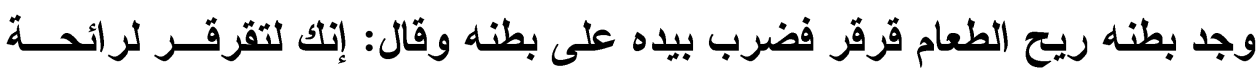

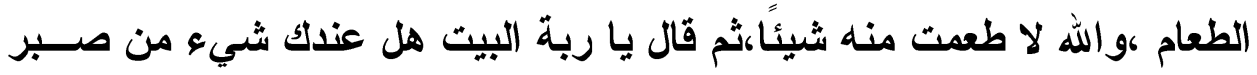

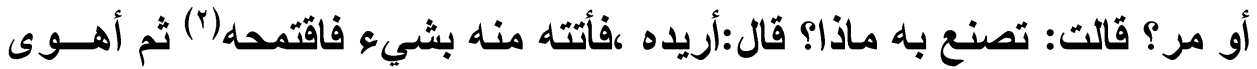

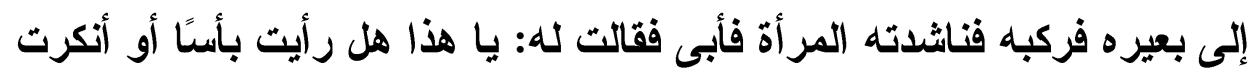

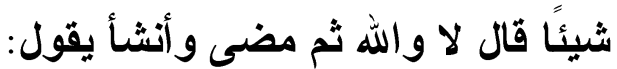

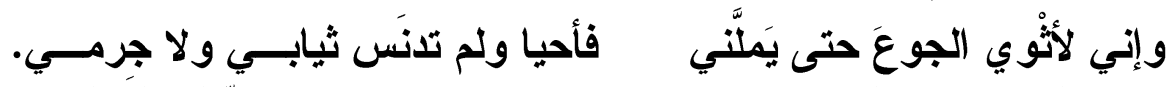

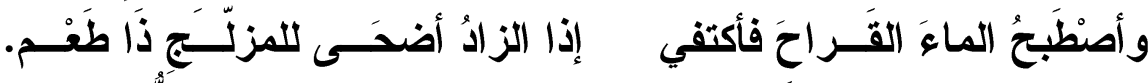

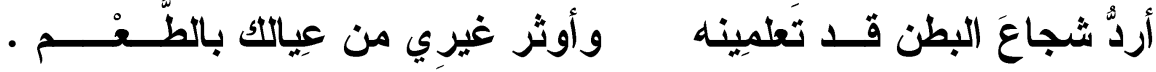




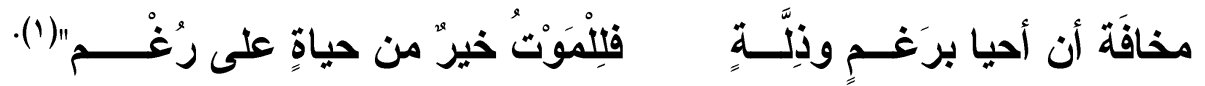

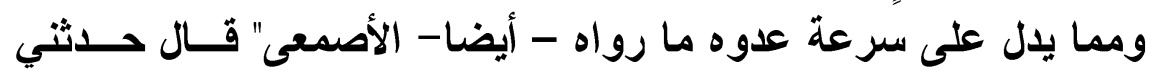

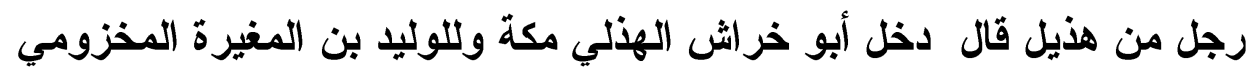

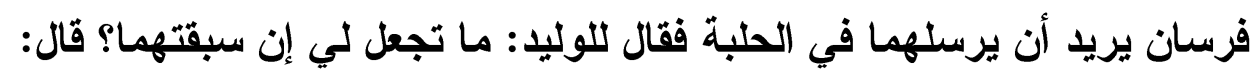

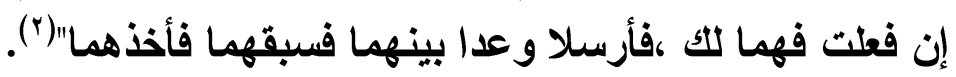
لقاؤه بعمر - رضى الله عنه:

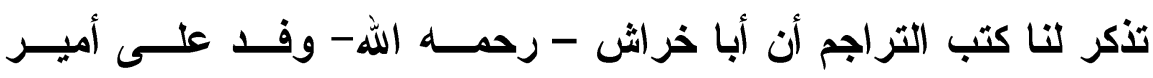

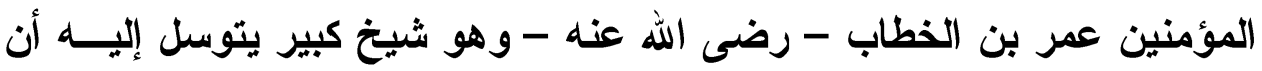

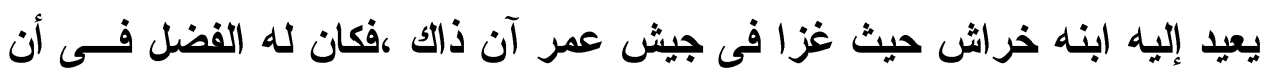

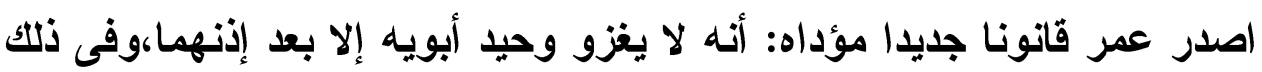

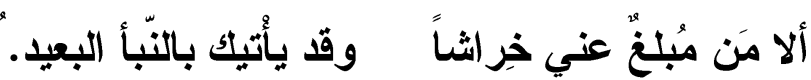

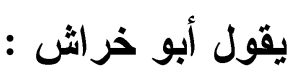

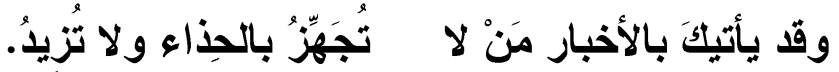

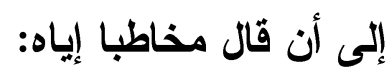

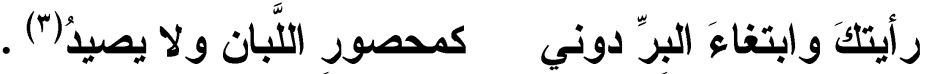

توفى - رحمه الله - فحى خلافة عمر بن الخطاب(؛) - رضى الله عنه - بعد

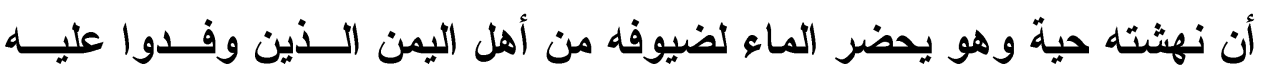

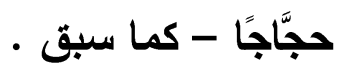

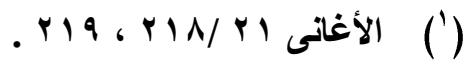

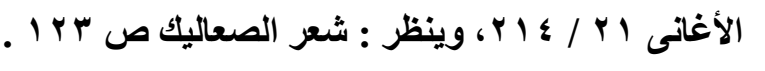

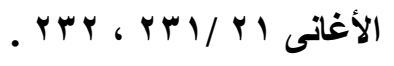

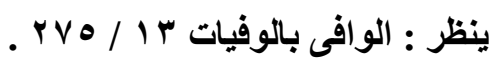




\section{فضالة بن شريك الأسدى(1)}

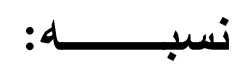

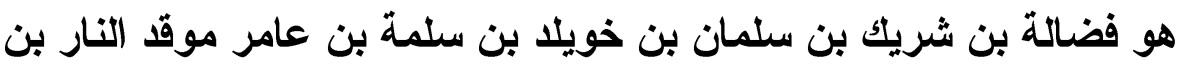

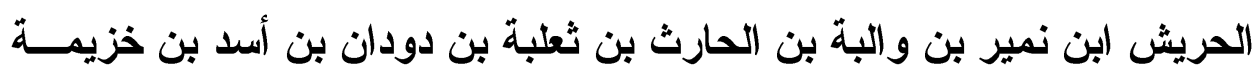

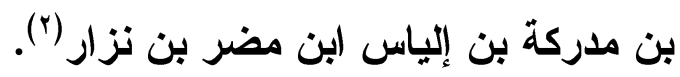

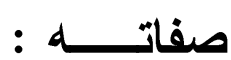
يصفه صاحب الأغاتى بقوله : " وكان شـاعر ا فاتكا صعلوكا مخضــرما أدرك

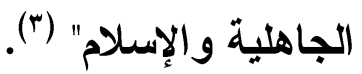

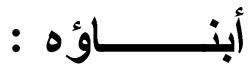

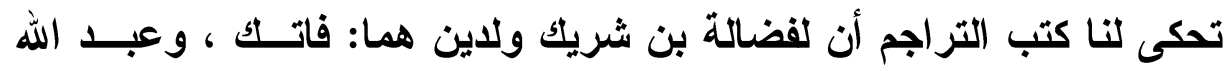

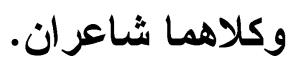

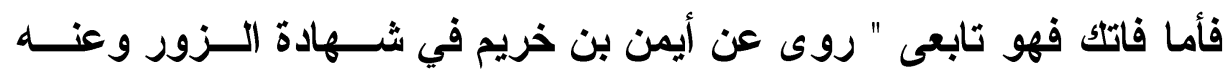

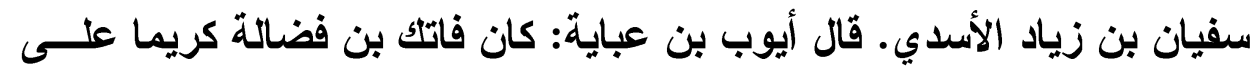

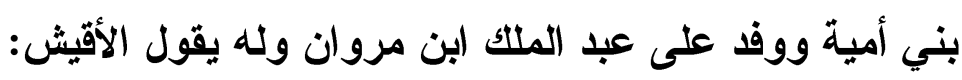

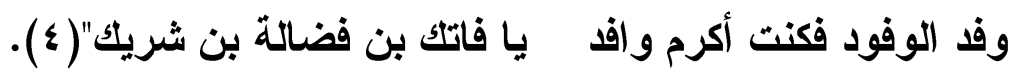

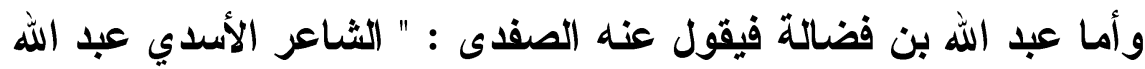

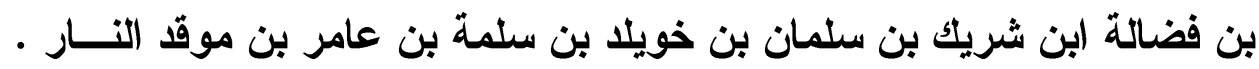

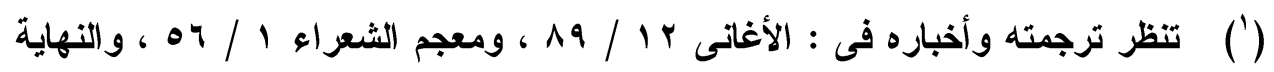

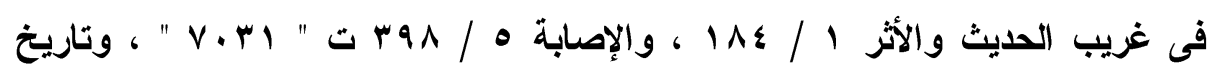

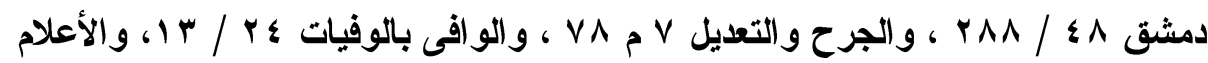

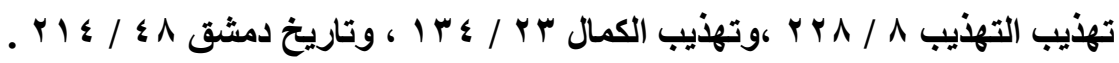




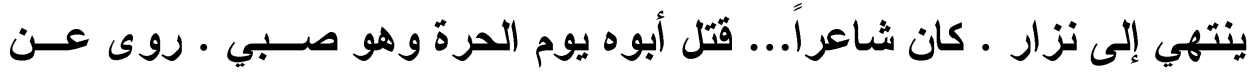

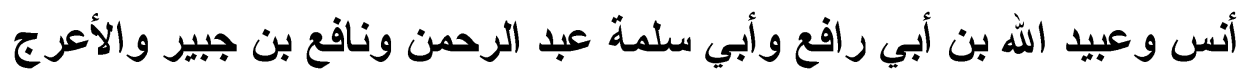

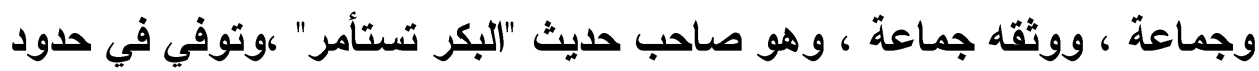

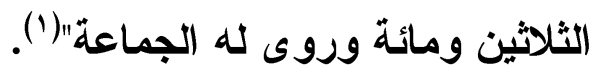

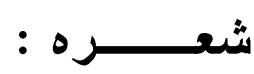

فضالة بن شريك من القلة بين شعراء الصعاليك الذين احتكوا بالمجتمعسات

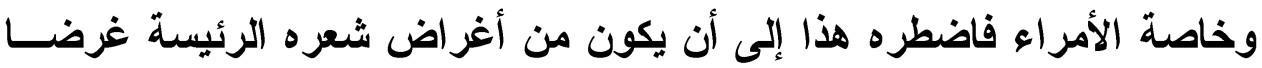

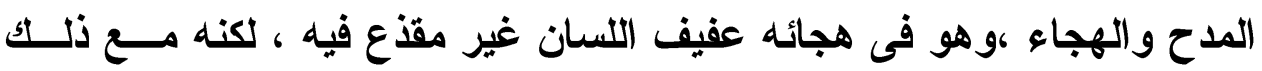
كان يبلغ من مذمومه مبلغًا أليمًاً (†) . فمن ذلك هجاؤه لعاصم بن عمر بن الخطاب حبيب حينما مر به وهو بالمدينــة

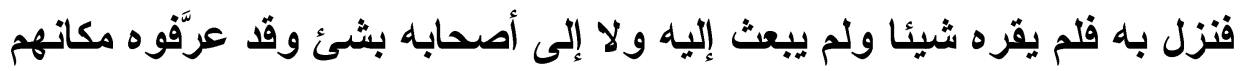

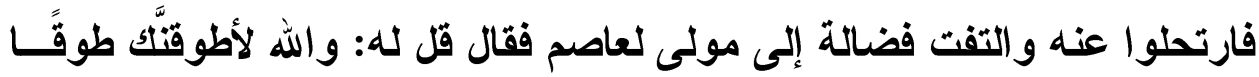
لا يبلى فقال يهجوه:

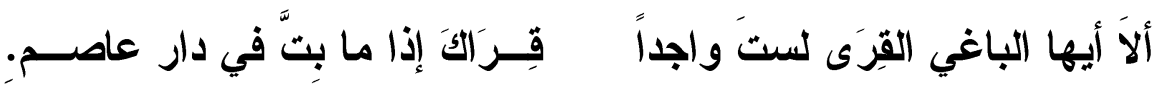

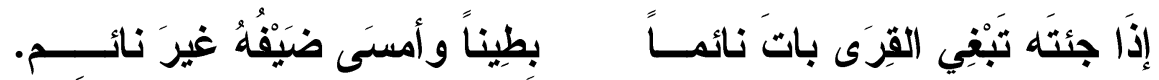

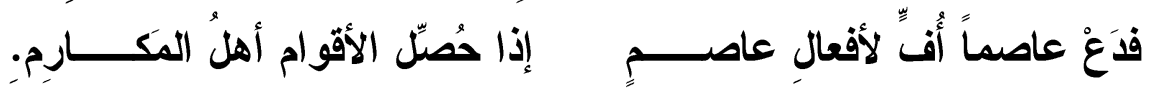

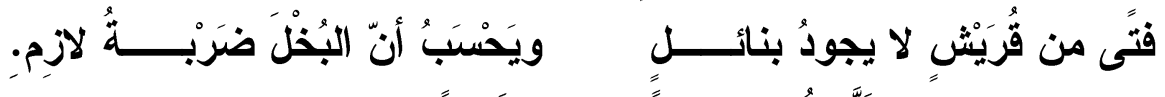

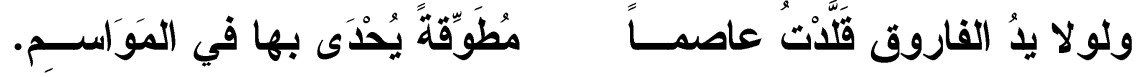

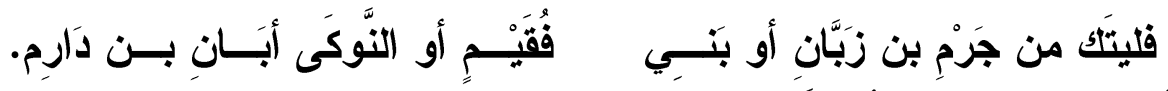

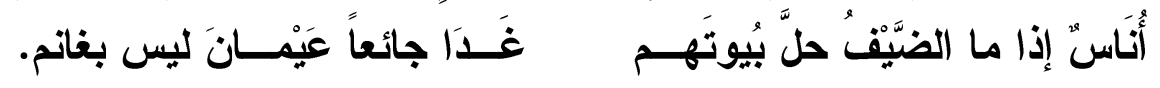


فلما بلغت أبياته عاصمًا استعدى عليه عمرو بن سعيد بن العسـاص وهـو

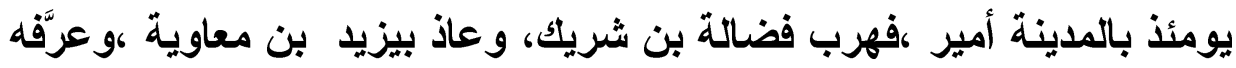
ذنبه وما تخوَّت من عاصم فأعاذه وكتب إلى عاصم يخبــره أن فضـــالة أتــــاه

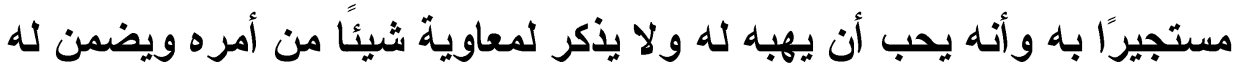

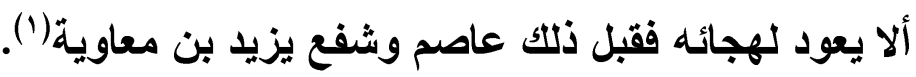

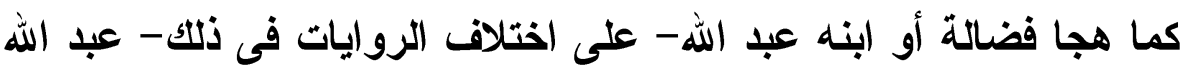

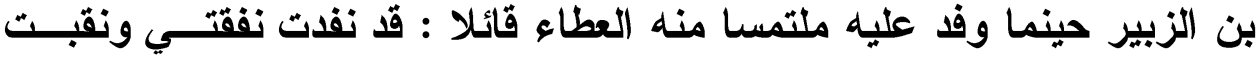
راحلتي فاحملني فقال له : أحضر راحتئ فأحضر ها فقال له : أقبل بها أدبر بها

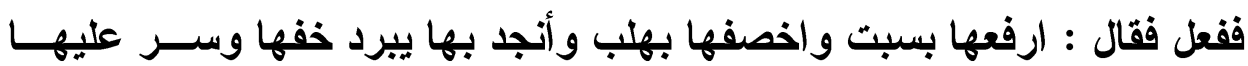
البردين تصح • فقال إنما أتيتك مستحملاً ولم أتثك مستوصفاً لعن الله ناقة حملتني إليك ـ فقــال ابـن

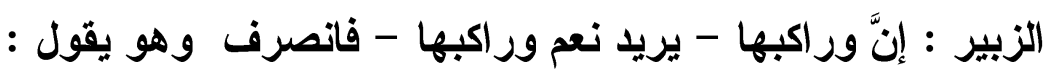
أقول لظلمتي شدوا ركابــي أفارق بطن مكة في ســـواد.

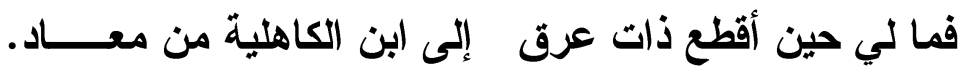

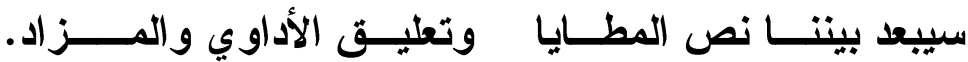

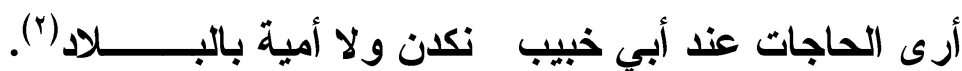

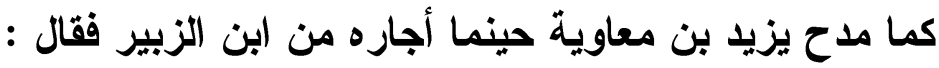

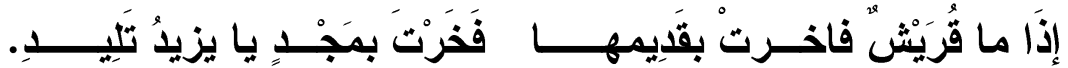

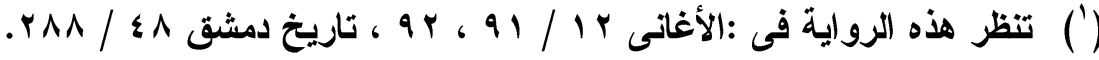

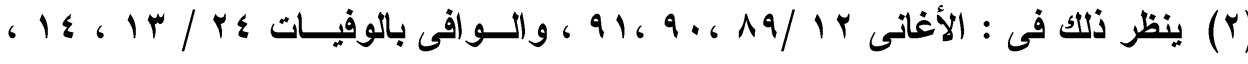
الكاهلية : إحدى جدات ابن الزبير لا أصل لها. قال ابن الزبير : علم النها أنهـا ألأم أمهـاتي

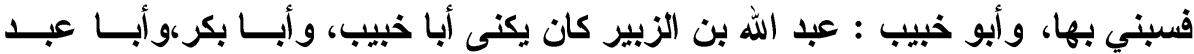

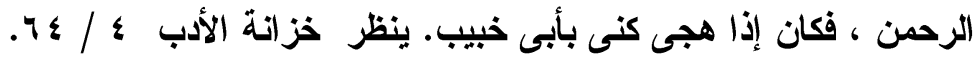




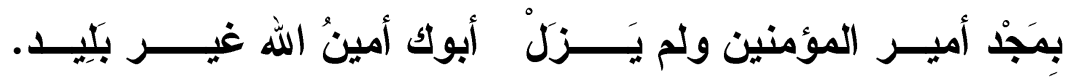

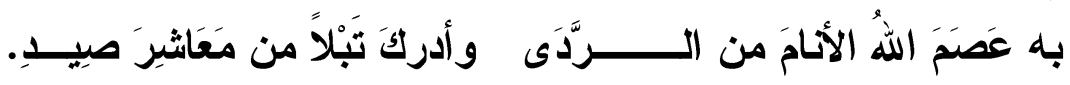

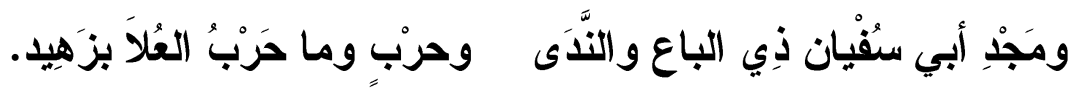

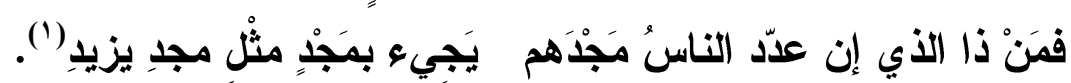

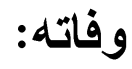

توفى فضالة قبل أن يلي عبد الملك بن مروان الخلافة(؟). 


\section{أبو الطححان القينى(')}

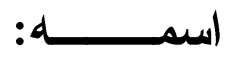

حنظلة بن الشرقي أحد بني القين بن جسر بن شيع الله من قضاعة(ז). وقيل فى اسمه ونسبه:ربيعة بن عوف بن غنم بن كنانة بن القين بن جسر (r).

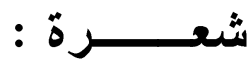

شعر أبى الطمحان فى معظمه يدور حول المدح إمـا لأجل فلك أســـره، وإمـــا لأجل إجارته من أعدائه. فمن مدحه لأجل فك أسره ما روى أنه "مدح بجير بن أوس بن حارثة بن لأم الطائي وكان أسيرا في يده فلما ملحه بهذه القصيدة أطلقه وجـز ناصــيته فمدحه بعد هذا بعدة قصائد وأول هذه الأبيات :

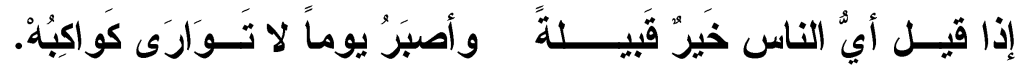

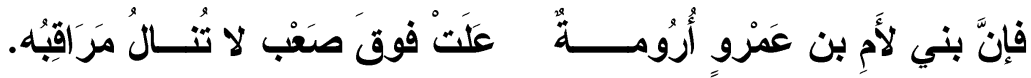

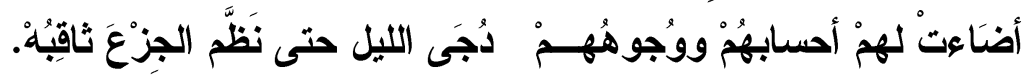

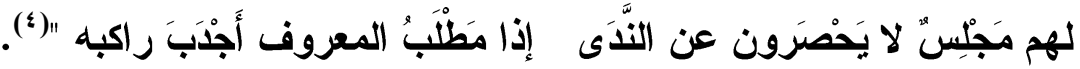
ومن ملحه لأجل إجارته من أعدائه ما روى أن أبا الطمحان" جنى جنايــة وطلبه السلطان فهرب من بلاده ولجأ إلى بني فزارة فنزل على رجل منهم يقال

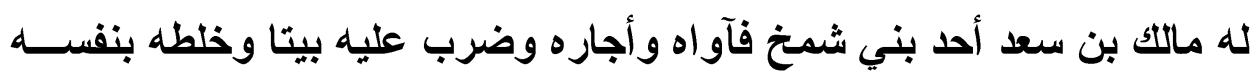

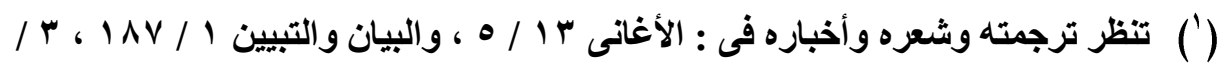

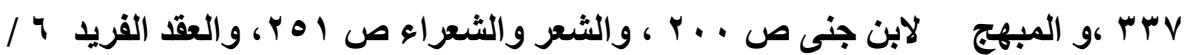

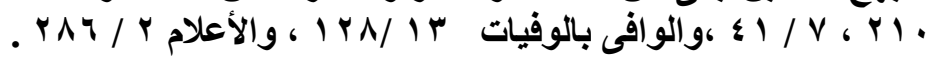

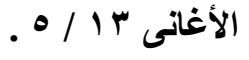

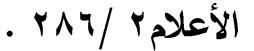

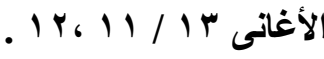


،فأقام مدة ثم تثوق يوما إلى أهله وقد شرب شر ابا ثمل منه، فقال لماتك: لولا

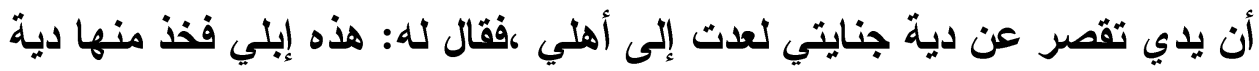

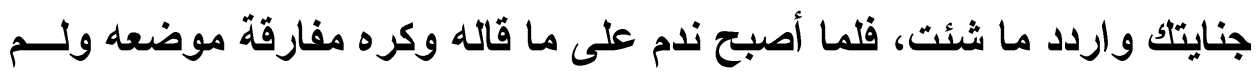

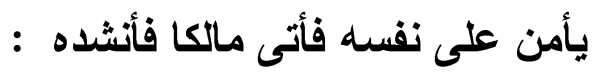

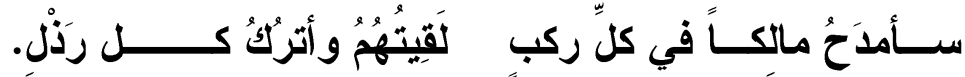

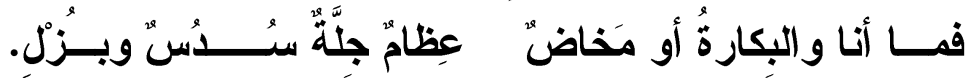

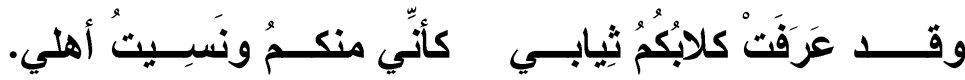

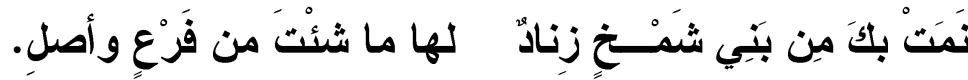

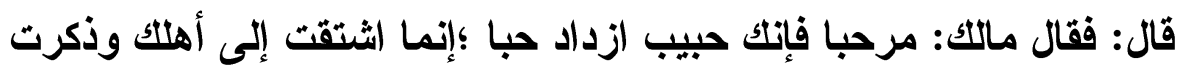
أنه يحبسك عنهم ما تطالب به من عقل أو دية فبذلت للك ما بذلت وهو للك على إنى كل حال فأقم في الرحب و السعة فلم يزل مقيما عذدهم حتى هلك في دارهم" (1).

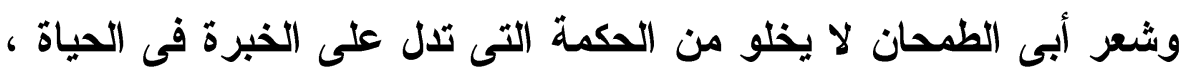

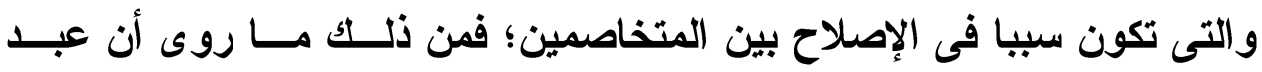

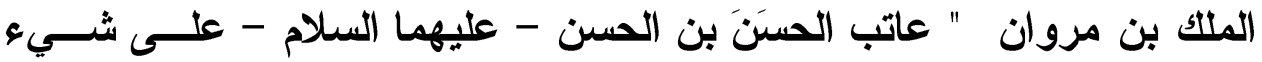
بلغه عنه من دعاء أهل العراق إياه إلى الخروج معهم على عبد الملث، فجعـل

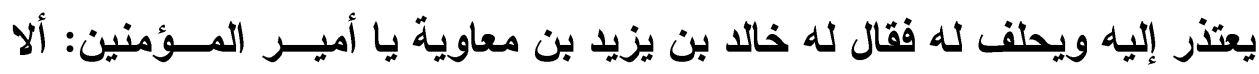

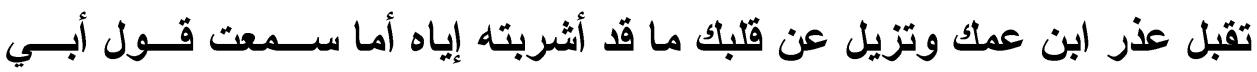
الطمحان القيني : - القان

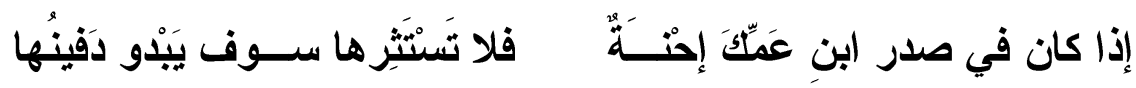

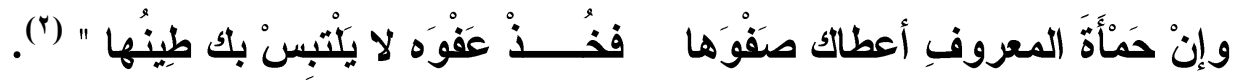


ما ورد علي شعره من نقد :

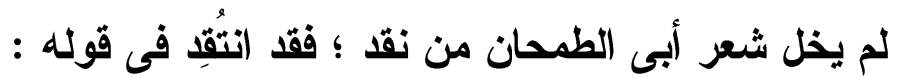

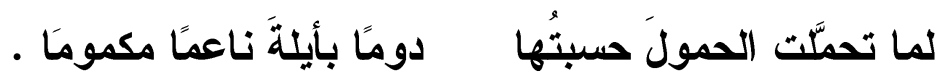

و الاوم : شجر المقل ، وهو لا يكم ، و إنما يكم النخل (') مخالفته لصفات الصعاليك: من خلال أخبار أبى الطحان نلاحظ عليه ملاحظتين شذ بهما عن أخص ما يميز الصعاليك : هن جلئ إحداهما : إسفافه وتنزله إلى أعمال بنفر منها خلـق الصــــاليك ؛ فالصــعاليك

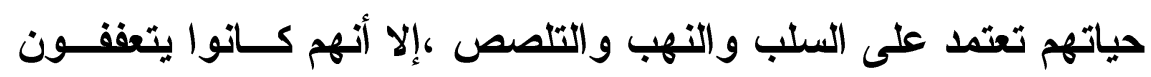

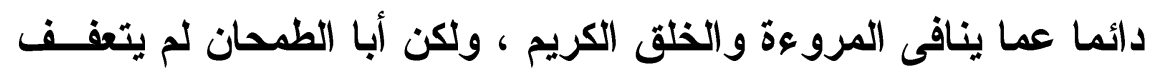

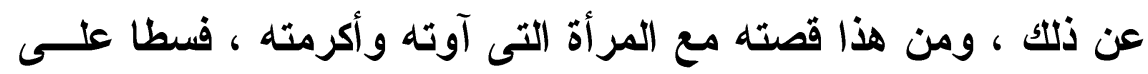

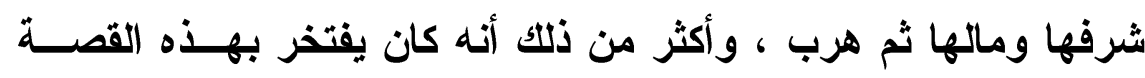
وهى المعروفة بقصة الدير (†)

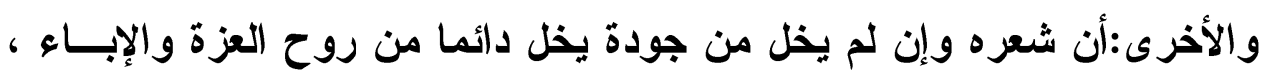

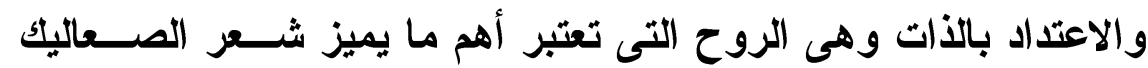

وأحاديثهم فى أنفسهم (") صفاتـــــــــ يصفه أبو الفرج بقوله : " كان أبو الطمحان شاعرًا فارسًا خاربًا صــطلوكًا

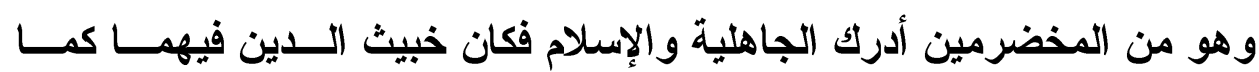

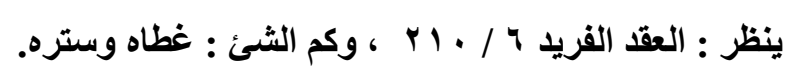

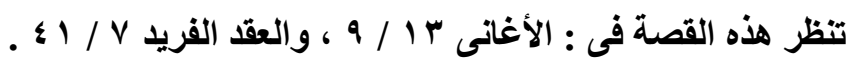

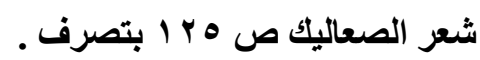




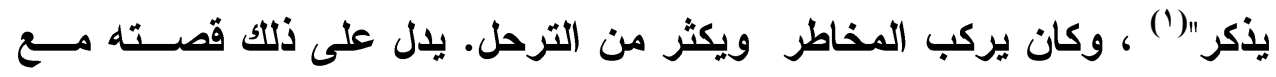

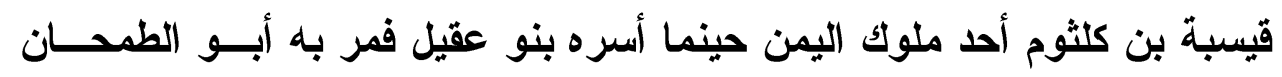

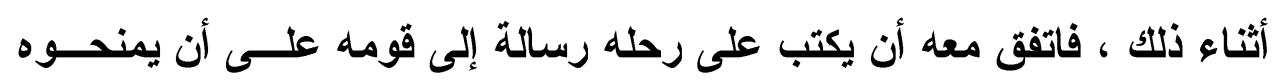

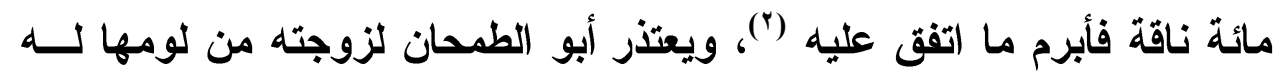

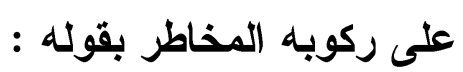

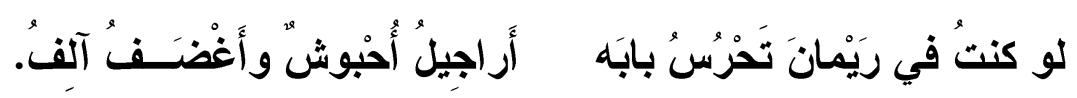

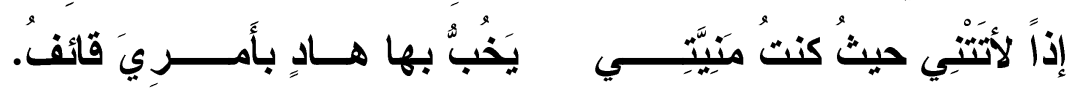

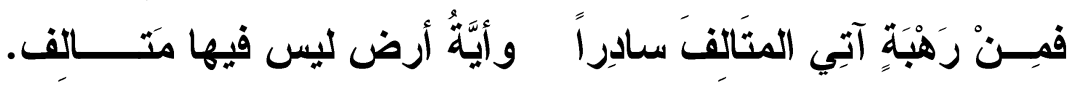

وفاته:

توفى أبو الطحان فى سنة ثلاثين من الهجرة النبوية (ب).

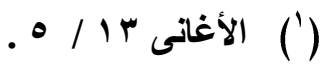

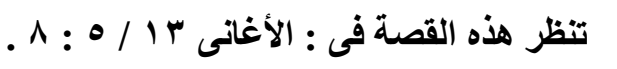

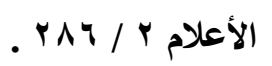


- rON r

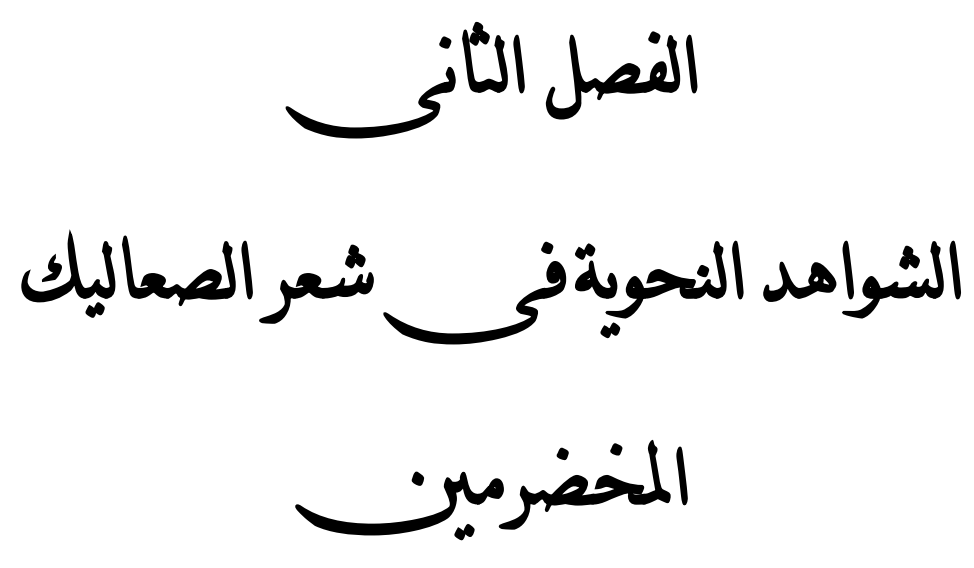


ظهور الضمة على ياء المنقوص فى حالة الرفع ضرورة

$$
\text { وقال أبو خر اش: }
$$

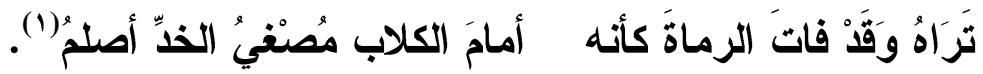

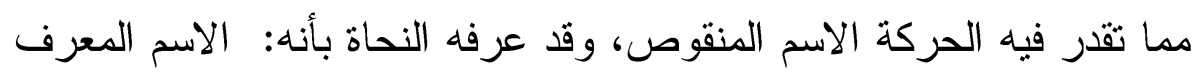

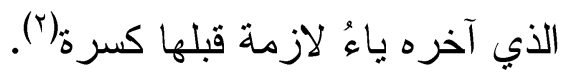

وتقدر فيه الضمة في حالة الرفع، و الكسرة في حالة الجر، فإن كان منصوبًا ظهرت الفتحة على يائه.

و المنقوص إما أن يكون محليَّ بـــأله" أو مضافًا، و إما أن يكــون مجــردًا

فإن كان محلىً بـ "أل" أو مضافًا ثبتت ياؤه في حالتي الرفع و الجر ساكنة،

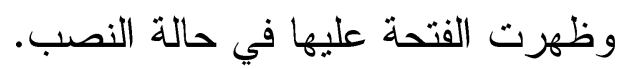

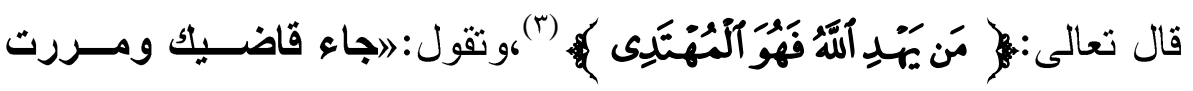

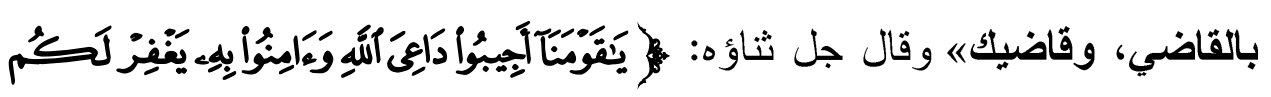

(') البيت من الطويل من قصيدة له مطلعها:

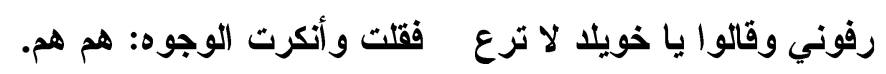

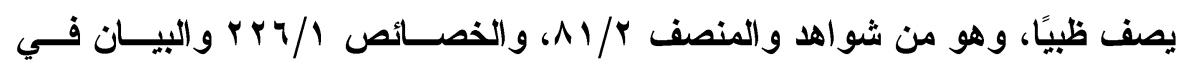

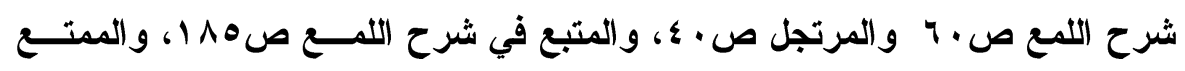

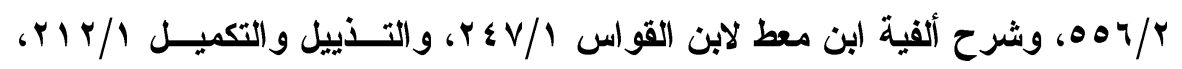

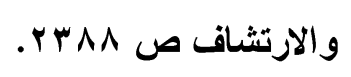

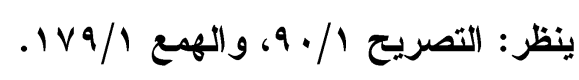

الأعراف (IVA) ( 


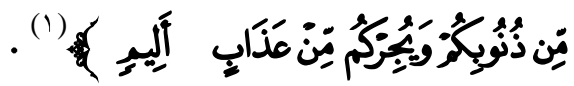

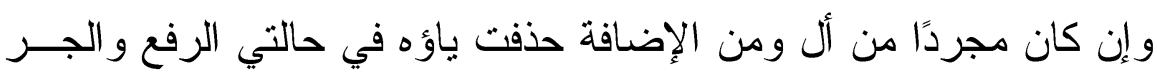

؛لاجتماعها ساكنة مع التنوين بعد حذف الضمة أو الكسرة عنها منونة مع الفـتح

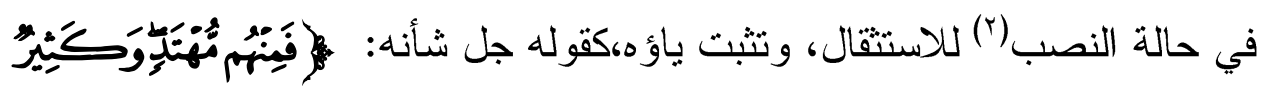

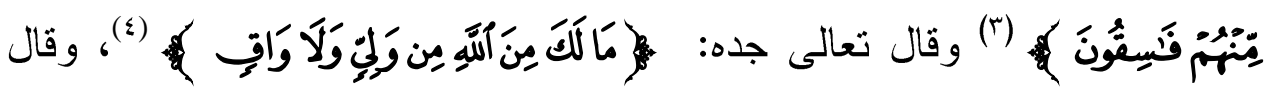

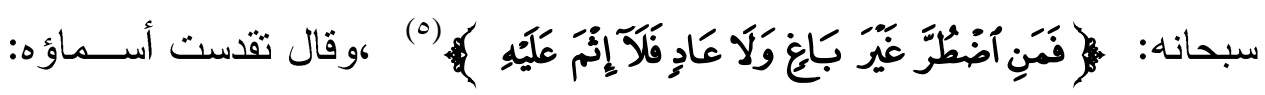

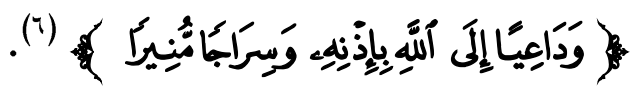

هذا حكم المنقوص من جهة الإعراب، فإذا ظهرت الضمة أو الكسـرة فـي آخره فهذا يعد من قبيل الشاذ الذي يحفظ و لا يقاس عليه.

$$
\text { وقد ظهرت الضمة في آخر المنقوص في قول أبي خر اش: }
$$

تراه وقد فات الرماة كأنه أمام الكلام مصغيُ الخد أصلم.

فالشاهد فيه قوله: اكأنه... مصغيُ الخده حيث أظهر الضمة آخر الاسم

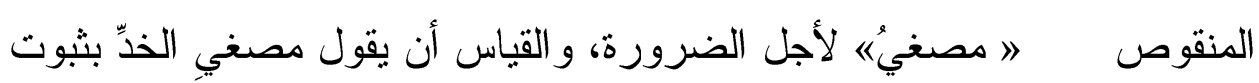

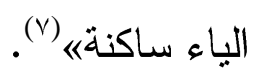

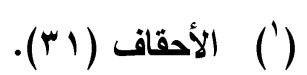

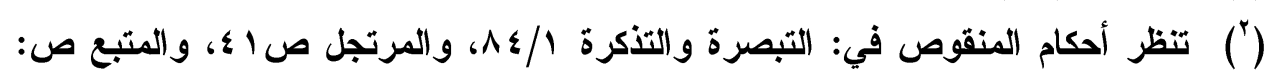

$$
.1 \wedge r-1 \Lambda \text {. }
$$

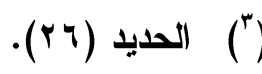

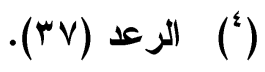

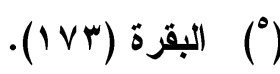

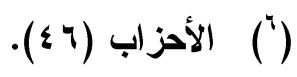

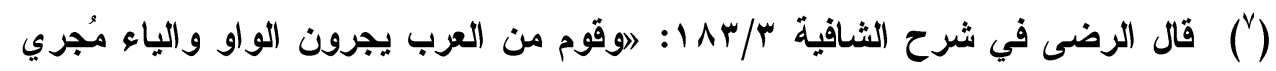


ويروي البيت بنصب 》مصنيَ) على الحال، وظهور الفتحة على الياء جريًا على القاعدة، و عليه فلا شاهد.

وقد رجح بعض النحاة رواية النصب على رواية الرفع اعتمادًا على صـحة المعنى.

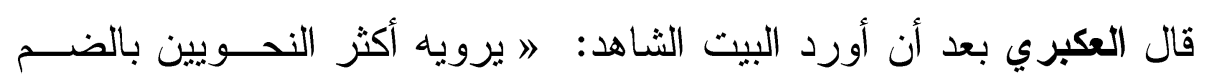

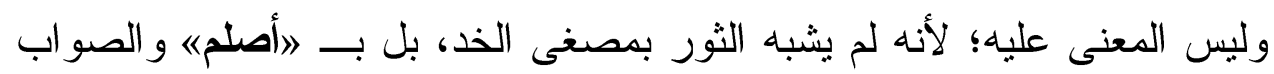

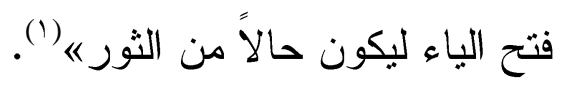

وقال ابن القواس: افالأكثر يروونه برفع 》مصغيه و الأجود نصبه علـى الحال؛ لأن المعنى عليه؛ إذ المراد تشبيه الثور بالأصلم حال الإصغاءه (r).

$$
\text { اللغــــة }
$$

مصغي الخد: يميله كأنه يتسمَّع، أصلم: مستأصل الأذنين. ويروي كما سبق - برفع "(مصغيه ونصبه.

حمل الكلام على الابتداء إن صح أكثر من حمله على البلاية

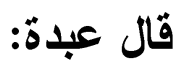

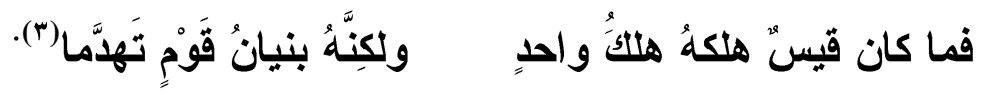

الصحيح في الاختيار فيحركون ياءُ 》 الرامي" رفعًا وجرًا وياء (ايرمى) رفعًا. أهـ.

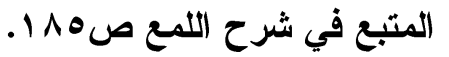

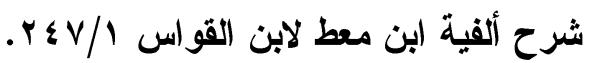

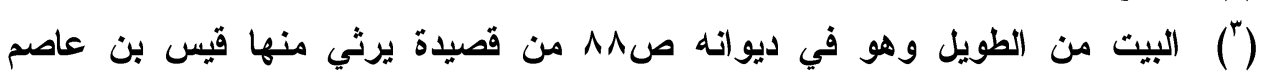
المنقري، سيد بن منقر ، وقبله: 
من أقسام البدل بدل الاشتمال، ويعني به: بدل شيءٍ من شيءٍ يشتمل عامله

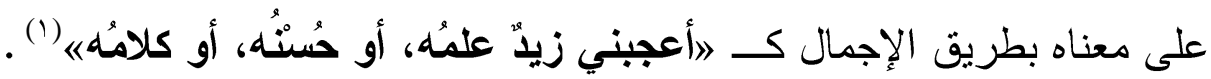
يقول ابن يعيش:» و المر اد بالاشتمال:أن يتضمن الأول الثـاني فــفهرم مــن

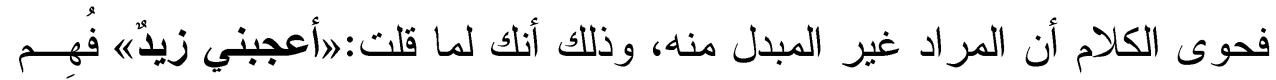

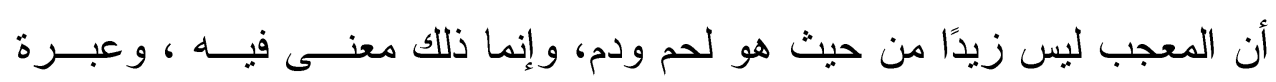

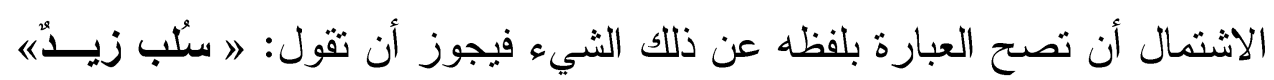

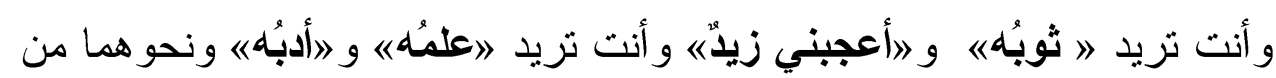
المعاني" (r)

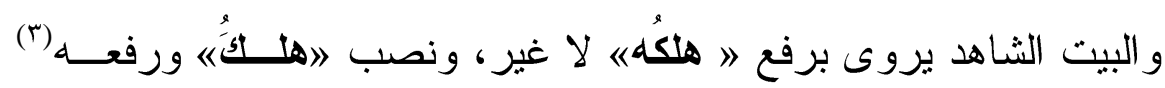

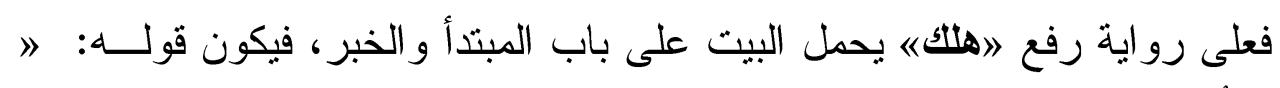

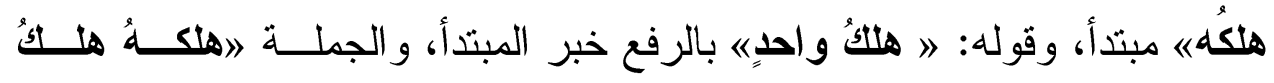

$$
\begin{aligned}
& \text { واحل《 في موضع نصب خبر 》 كان) . } \\
& \text { هذا هو الأكثر. }
\end{aligned}
$$

يقول سيبويه:» تقول:» رأيت متاعكَ بعضُه فوقَ بعضٍٍ إن جعلت " فوقًا

عليك سلام الله قيسن بن عاصمٍٍ ورحتُّهُ ما شاء أن يترحما.

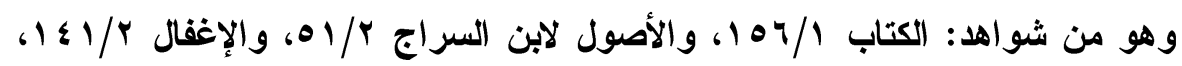

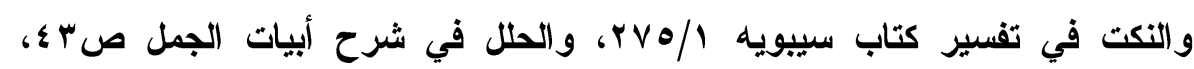

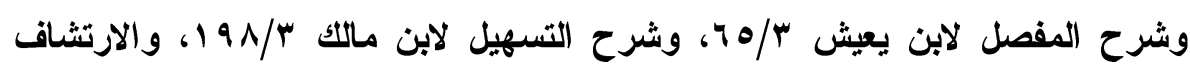

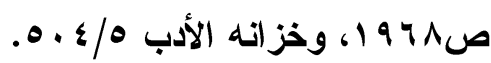

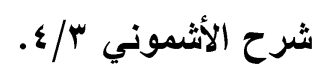

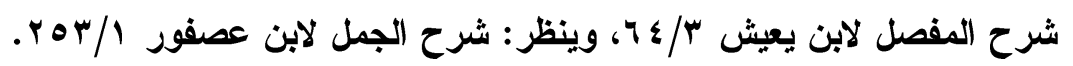

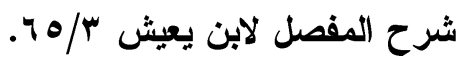


في موضع الاسم المبني على المبتدأ، وجعلت الأول مبتدأ كأنك قلـــ: 》 رأيــــ

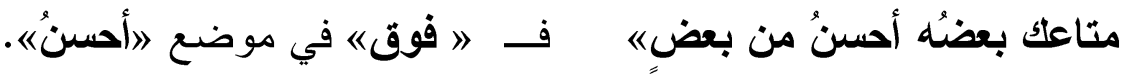
و إن جعلته حالاً بمنزلة " مررت بمتاعك بعضِه مطروحًا وبعضِه مرفوعًا . نصبته؛ لأنك لم تبن عليه شيئًا فتبتدئه.... و الرفع في هذا أعرف؛لأنهم شبهوه بقوللك:» رأيت زيدًا أبوه أفضل منه «ـ...

$$
\text { وإن نصبت فهو عربي جيده" (1) . }
$$

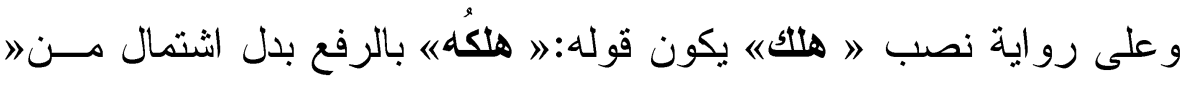

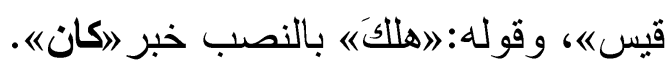
و النصب و إن كان قريبًا جدًا. كما ذكر سيبويه. إلا أنه لبس في القوة بمنزلة الرفع فهو أقيس. يقول أبو حيان : " و إذا صح فيما كان بدلا أن يكون مبتدأ ، وما بعده خبـر

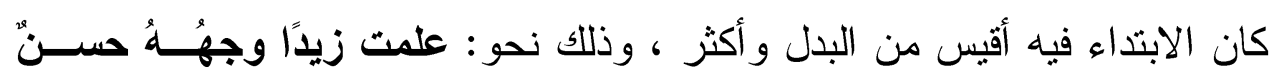

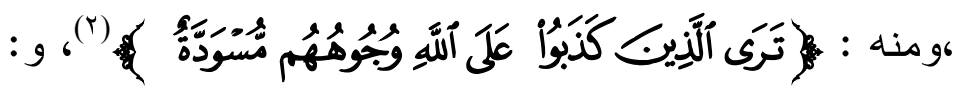
فما كان قيس هلكه هلك واحد ... « (").

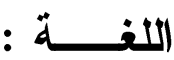

قيس : هو قيس بن عاصم المنقرى ،أحد أمسـر اء العـرب و عقلائهــم فـى

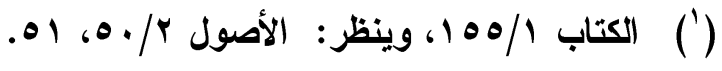

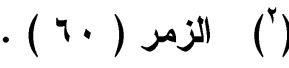

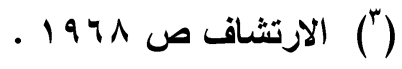




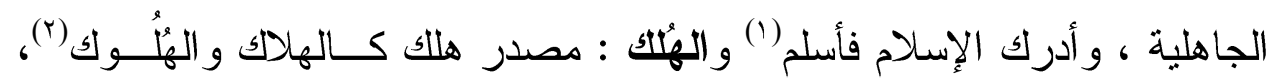
و الأبُنيان: مصدر استعمل استعمال الأسماء ، و أر اد به المبنى نفسه؛ لأن البنيــان

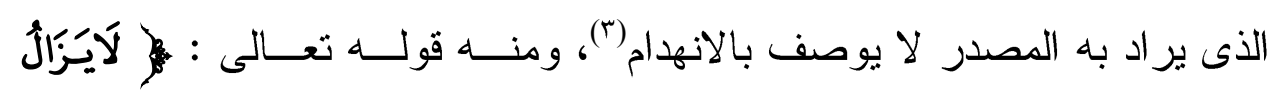

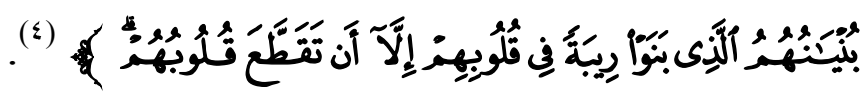
تعدد الخبر لمبتدأ متعدد حكمًا

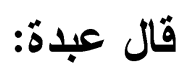

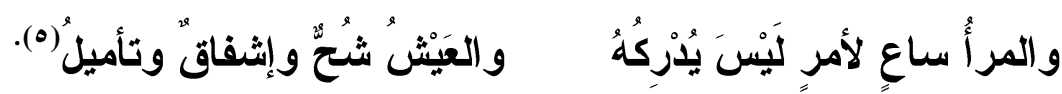

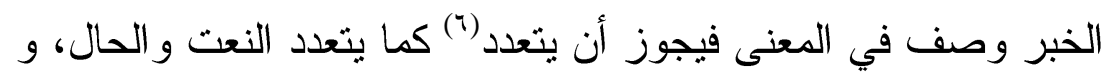

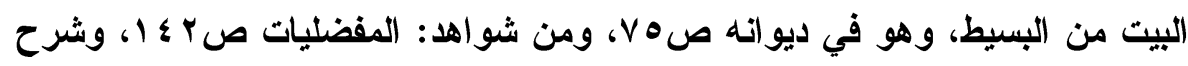

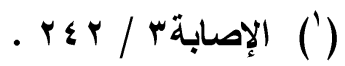

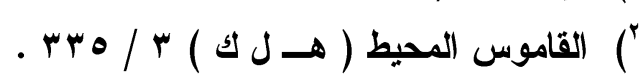

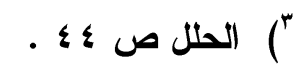

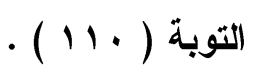

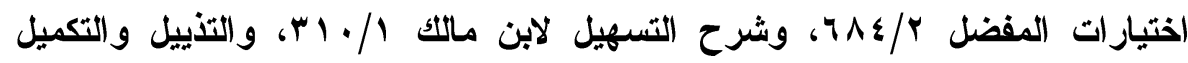

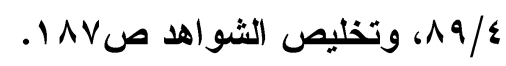

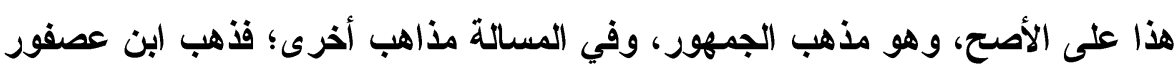

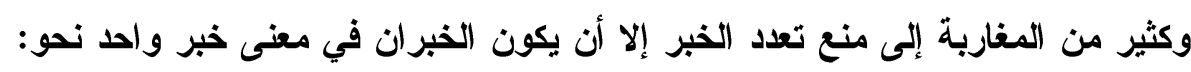

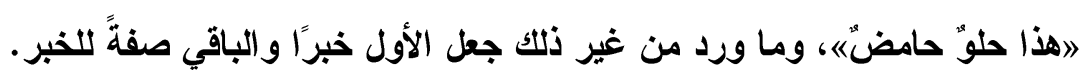
وبعضهم يجعل الباقي خبرًا لمبتدأ مقدر. وذهب بعضهم إلى أنه إذا اتحدت الأخبار في الإفراد و الجملة جاز ، وإن وإن اختلفت بأن كان أحدها مفردًا والأخر جملة امتنع.

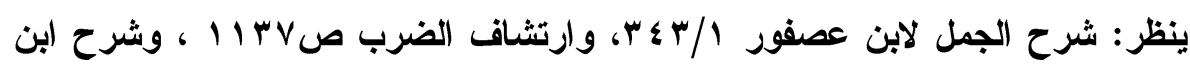

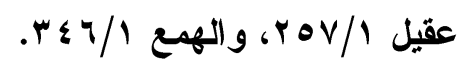




$$
\text { لتعدد الخبر صور (1) هي: }
$$

أولاً: أن يتعدد الخبر لفظًا ومعنى لا لتعدد المخبر عنه نحو قوله عزَّ مـن

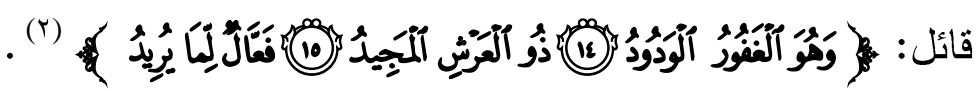

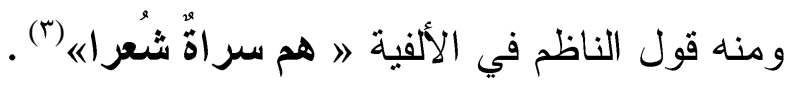

و هذا النوع يجوز فيه العطف وتركه()، و علامته صحة الاقتصار على واحد

$$
\text { واحد من الخبرين أو الأخبار (o). }
$$

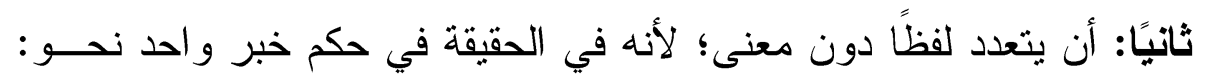

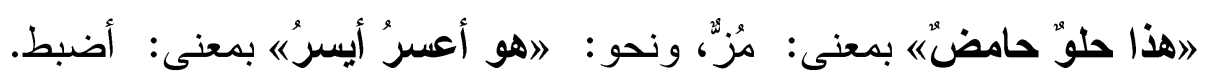

وهذا النوع يمتتع فيه العطف عند الجمهور خلافًا للفارسي في أحد قوليه(")؛

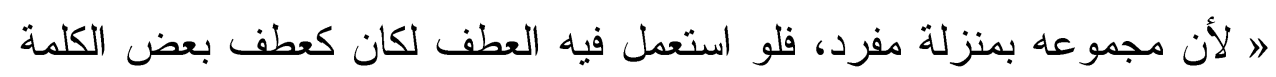

$$
\text { على بعضه" (v) }
$$

ثالثًا: أن يتعدد لفظًا ومعنى لتعدد المخبر عنه، وهو - أي هذا التعدد- إمــا

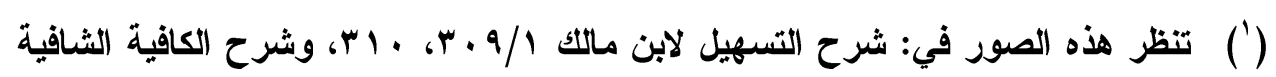

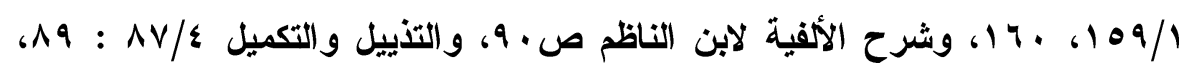

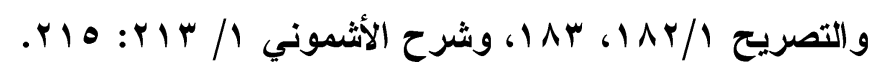

$$
\begin{aligned}
& \text { (") البروج (ع ا: 14) (14). }
\end{aligned}
$$

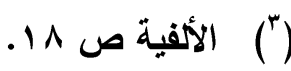

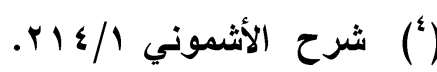

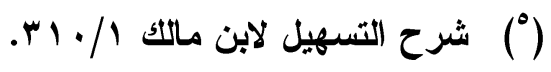

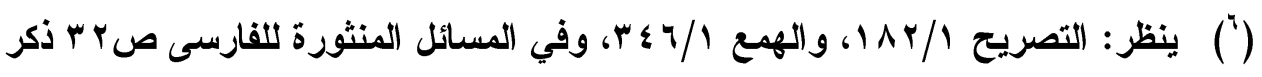

المثال دون التصريح بجواز العطف.

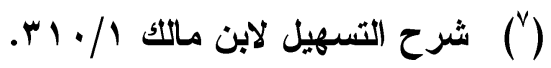




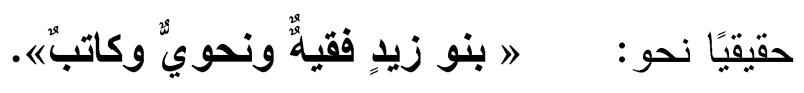

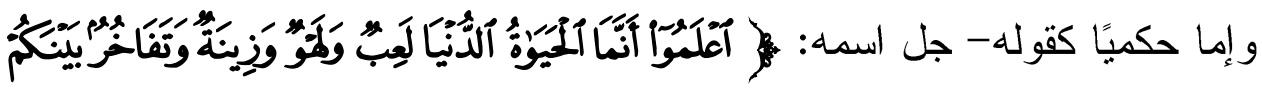

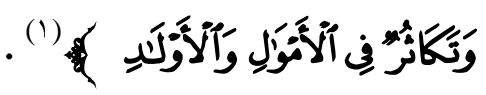

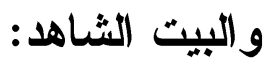

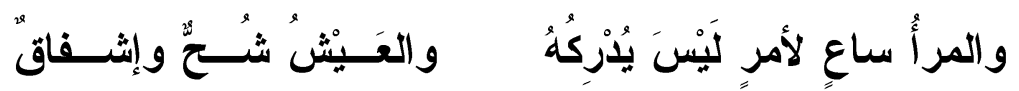

ونأميل.

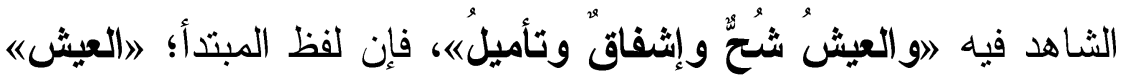

متعدد حكمًا؛ لأن العيش قد يكون شحًّا، وقد يكون إثفاقًا ،وقد يكون تأميلاً، فهو إذن - في حكم المتعدد، ومن ثم لزم العطف؛ لأن هذا النوع 》 يجب فيه العطف

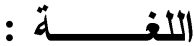

ألفاظ البيت و اضحة لا تحتاج إلى بيان.

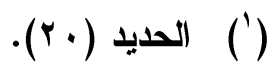

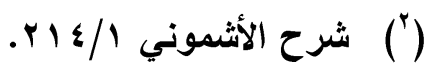




\section{اقتران الخبر بالفاء}

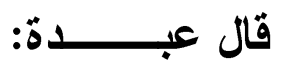

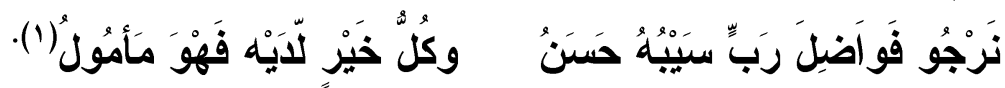

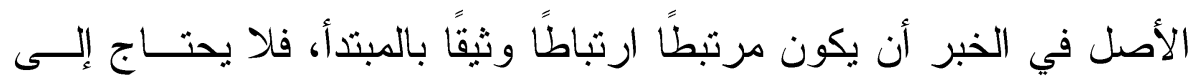

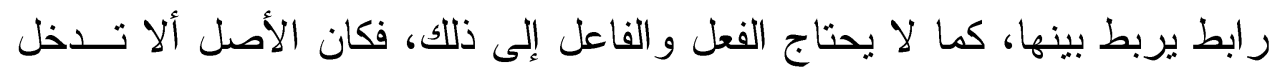

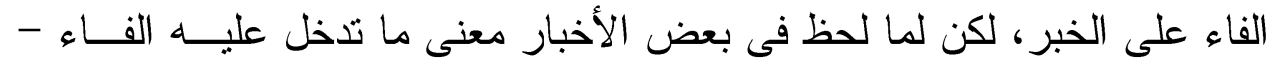

$$
\text { وهو الثرط و الجزاء - اقترنت بهاء لكاء). }
$$

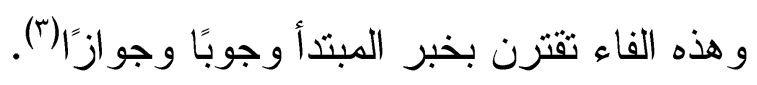

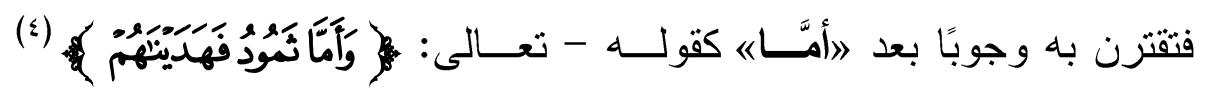

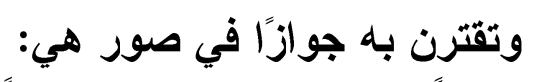

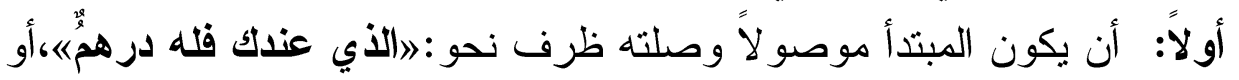

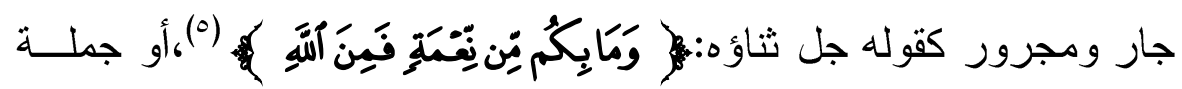

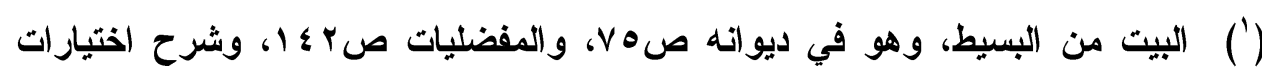

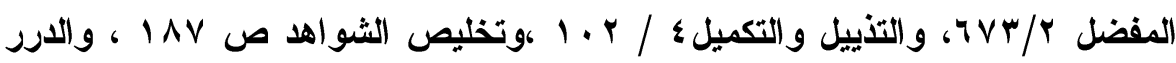

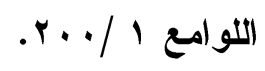

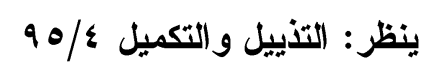

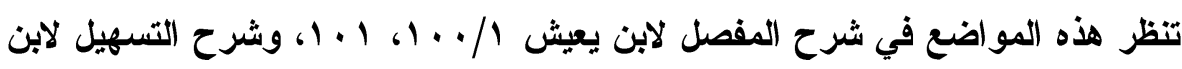

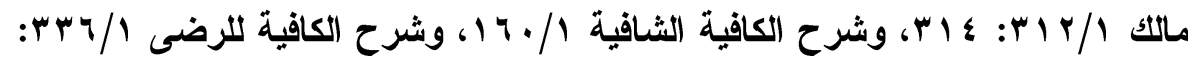

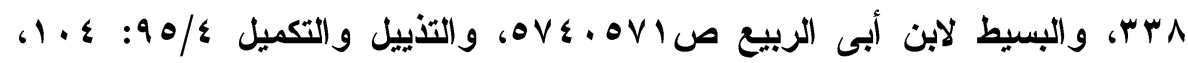

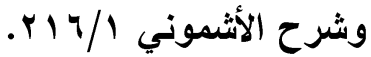

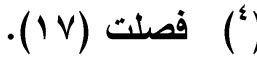

$$
\begin{aligned}
& \text { (') (النحل (OF). }
\end{aligned}
$$




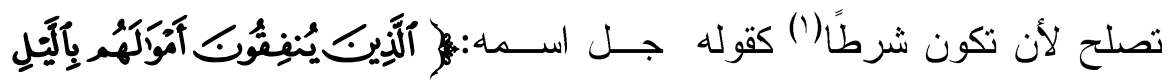

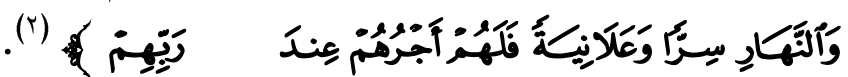

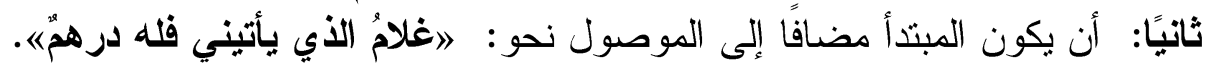

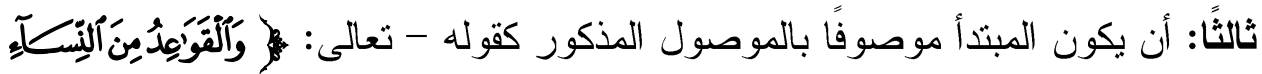

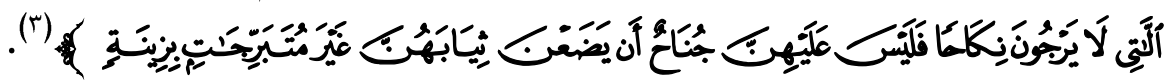

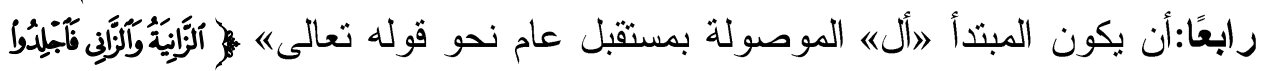

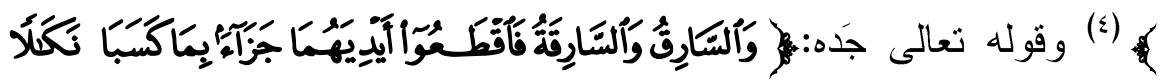

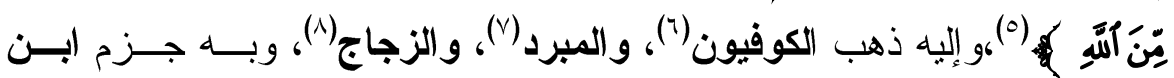

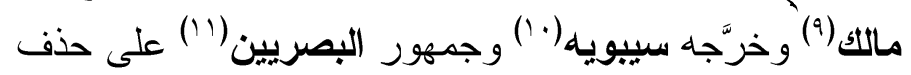

(') وهي الجملة الفطية غير الماضية، وغير المصدرة بأداة شرط أو حرف استقبال كالسين

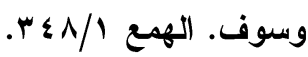

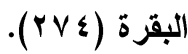

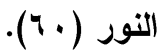

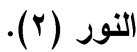

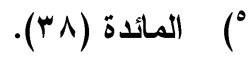

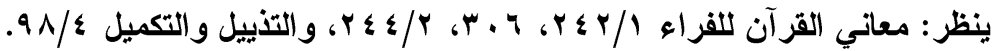

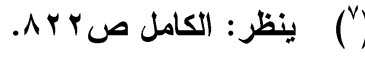

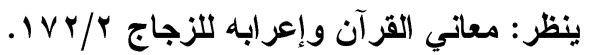

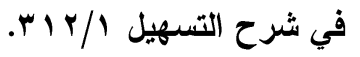

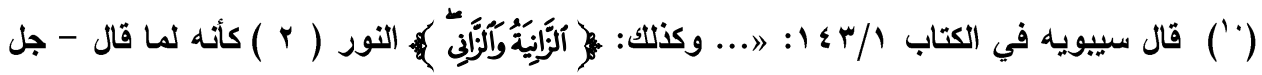

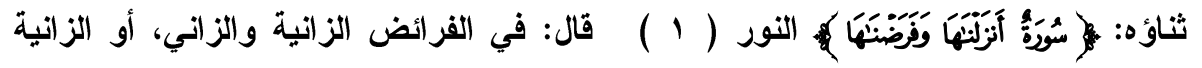

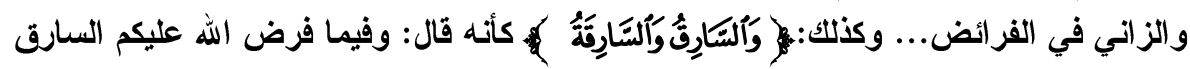

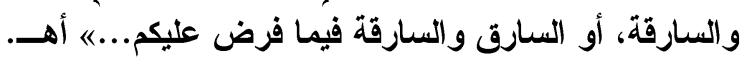

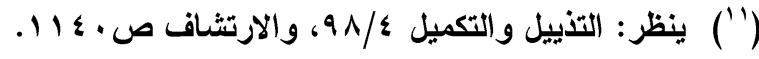


الخبر و التقدير في الآية الأولى:» فيما فرض عليكم الزانيــة والزاتـــ..." ودلَّ

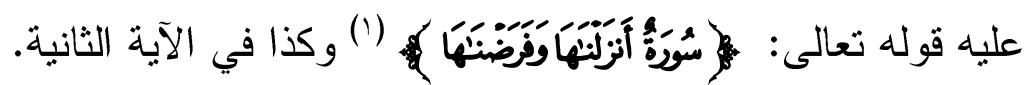

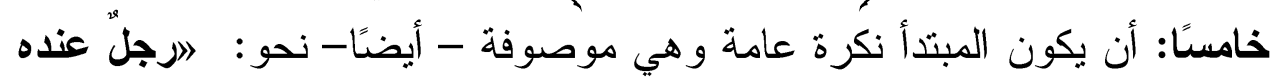

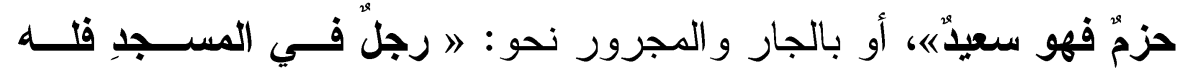

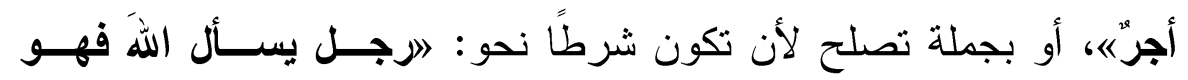
يُعطيهها.

سادسًا: أن يكون المبتدأ مضافًا إلى النكرة الموصوفة، وهو مشعر بمجازاة

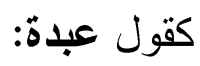

وكل خير لايه فهو مسئول.

و الثاهد فيه قوله: 》وكل خير لايه فهو مسئوله حيث اقتران الخبر بالفـاء فئاء

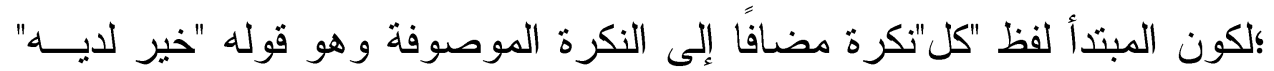

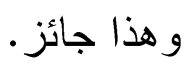

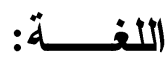

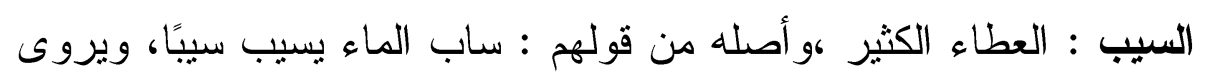

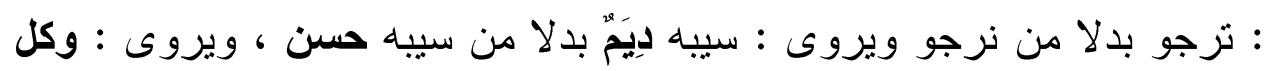

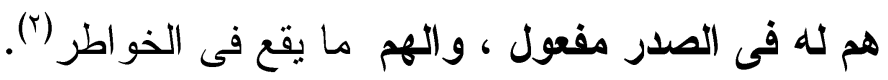




\section{الإخبار عن المبتدأ بلفظه.}

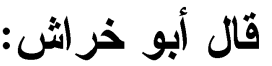

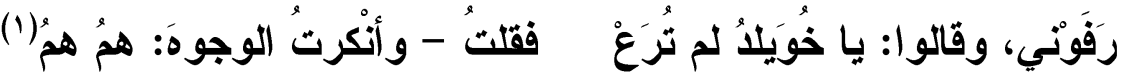

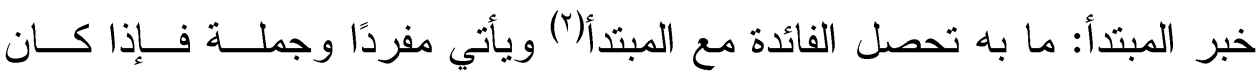

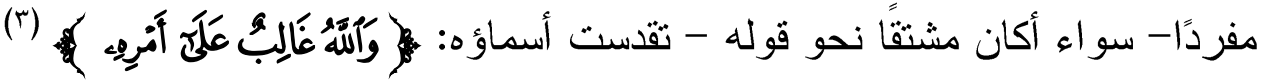

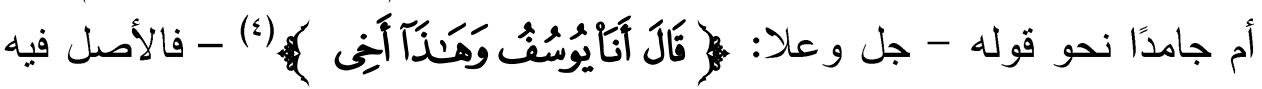

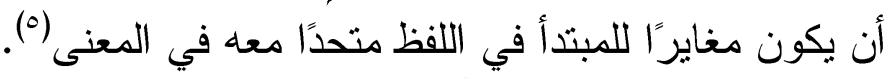

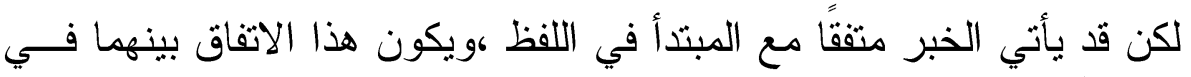

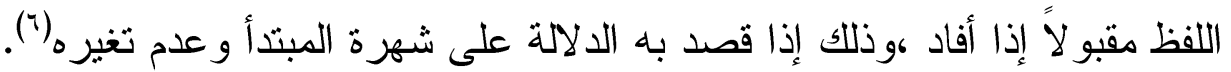
ومنه قول أبي خراش السابق.

البيت من الطويل، وهو من مطلع قصيدة له مكونة من ستة عشر بيتًا، ذكر فيها تفلته

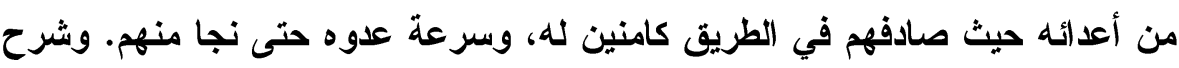

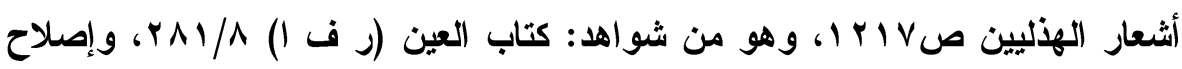

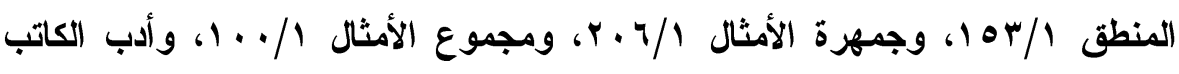

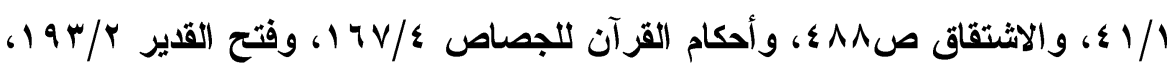

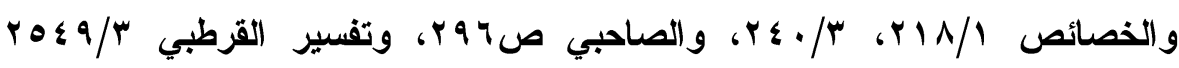

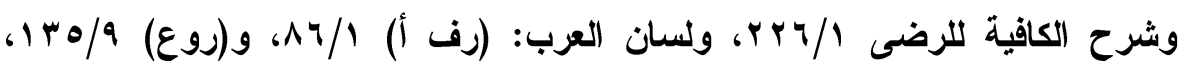

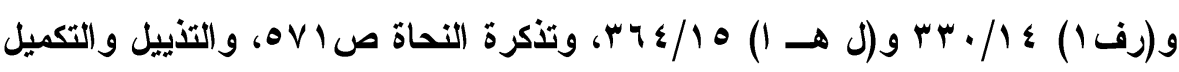

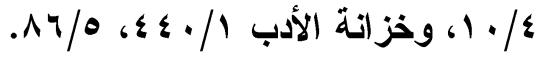

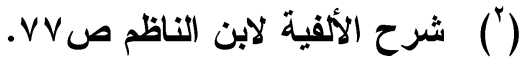

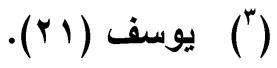

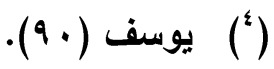

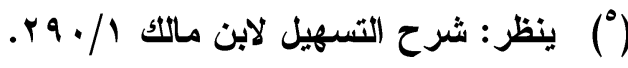

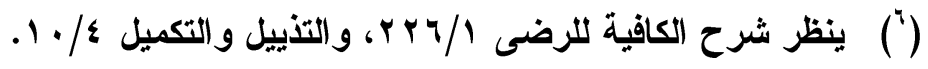




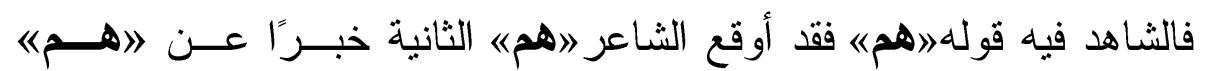

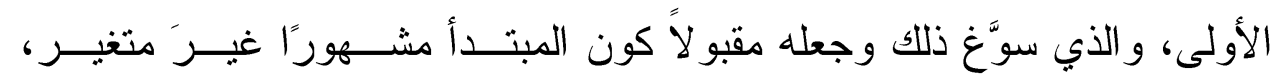

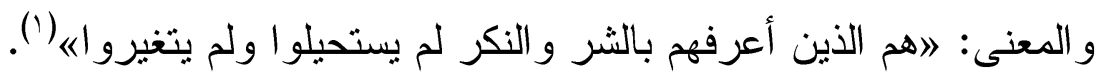

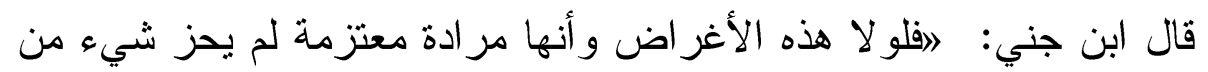

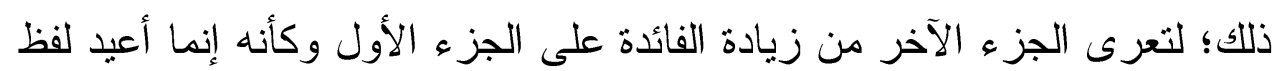

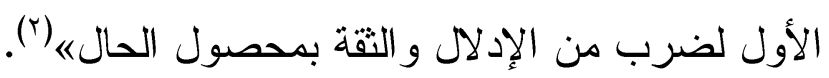

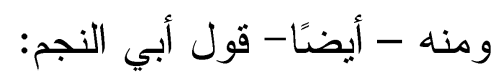

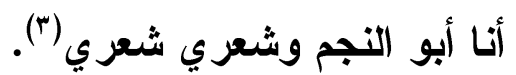

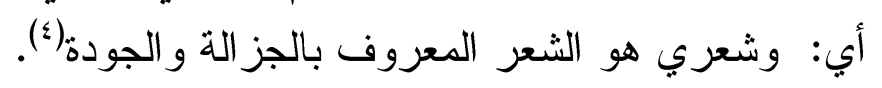

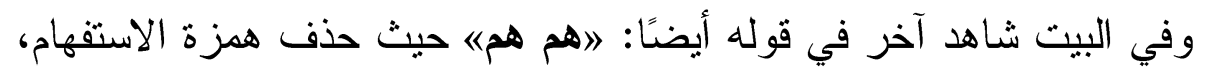

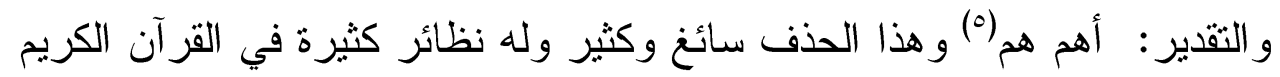

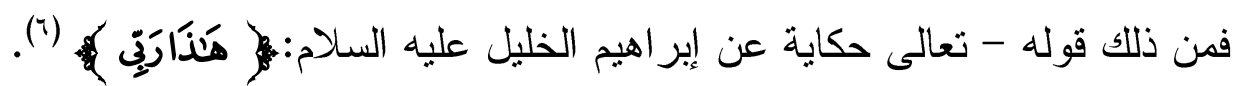

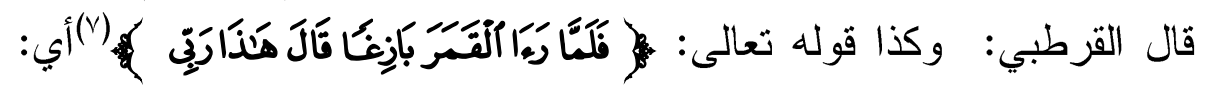

أهذا ربي... فأضمر ألف الاستفهام وهو كثير (^).

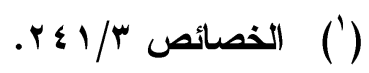

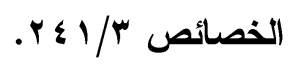

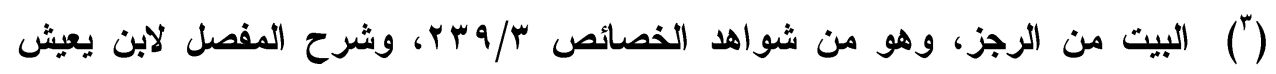

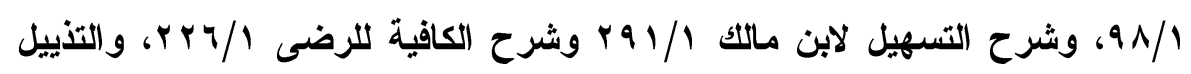

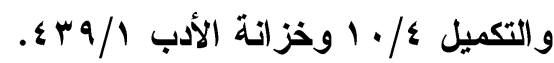

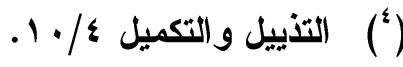

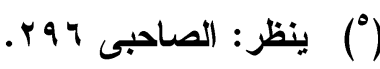

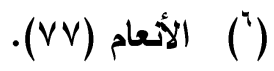

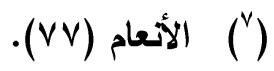

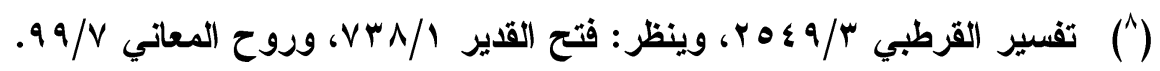




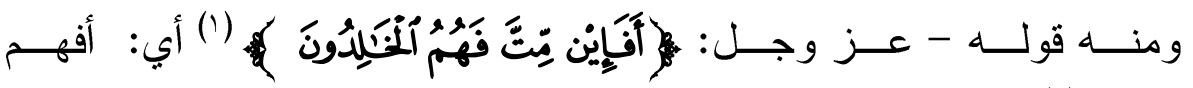

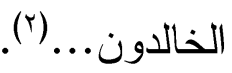

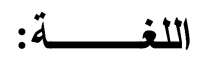

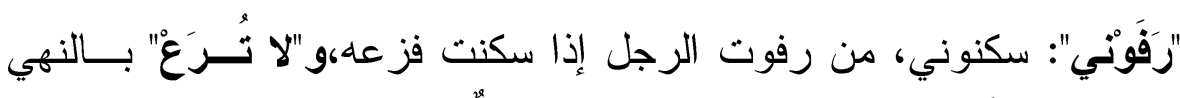

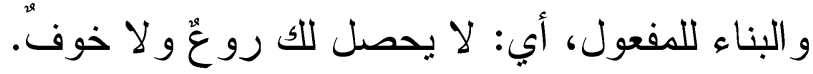

وخويلد: اسم الثاعر.

ويروي: رقوني (ّ) بدلاً من رفوني، لكن نقل البغدادي() عن كتاب التصحيف

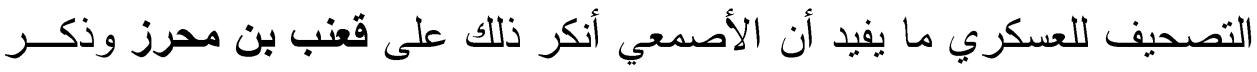
أنه تصحيف صو ابه: رفوني بالفاء.

حذف المبتدأ جوازًا

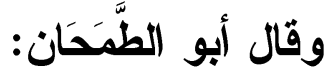

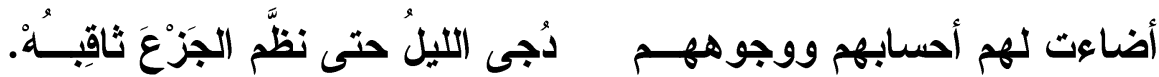

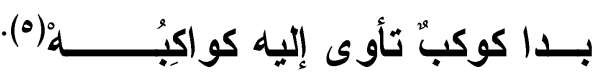

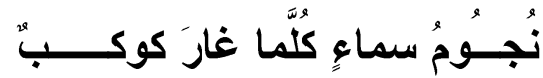

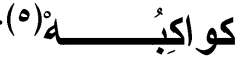

الأصل في المبتدأ والخبر الذكر، لأن المبتدأ - كما يقول ابن يعيش: لهعتمد

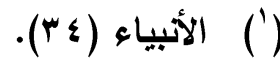

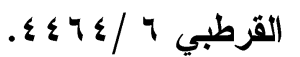

$$
\begin{aligned}
& \text { كما في التنييل والتكميل \&/. 1. 1. }
\end{aligned}
$$

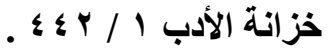

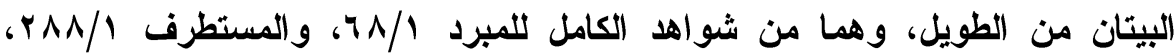

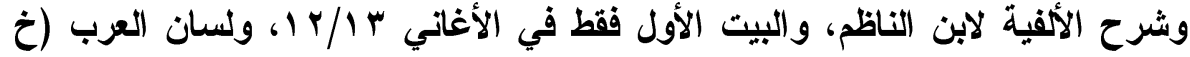

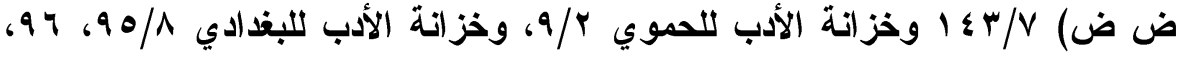

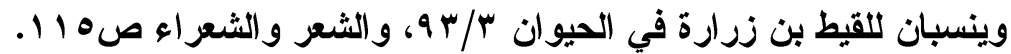




\section{الفائدة، و الخبر محل الفائدة فلا بد منهماه|"( ).}

لكن إذا دل على المحذوف دليل، أو وجدت قرينة تدل عليه جاز حذفه(؟).

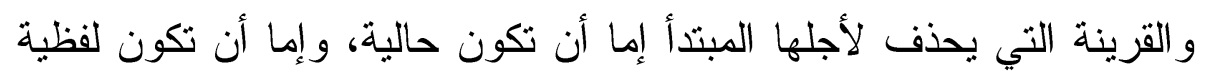

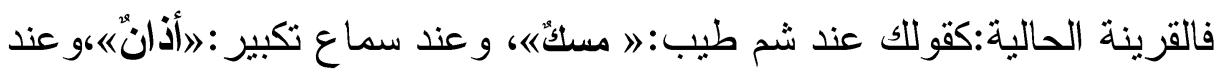

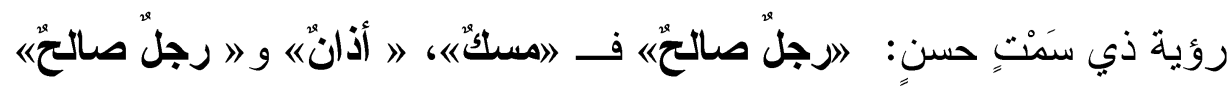

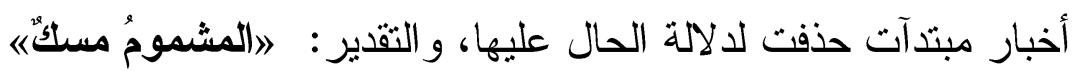

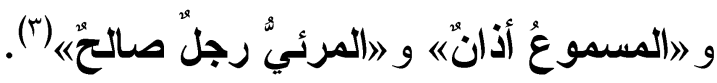

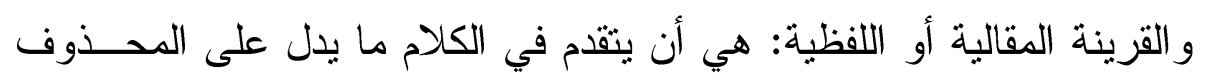

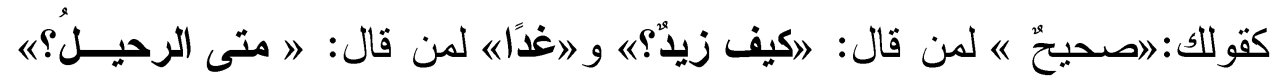

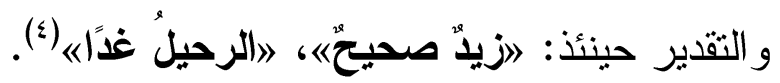

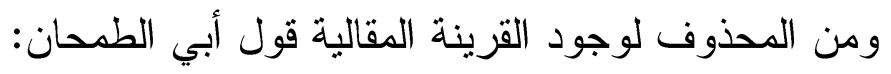

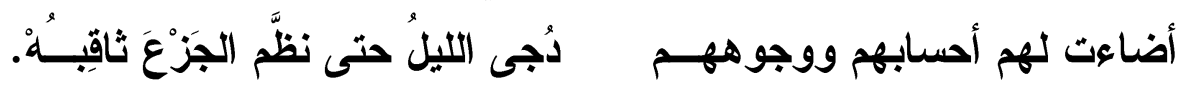

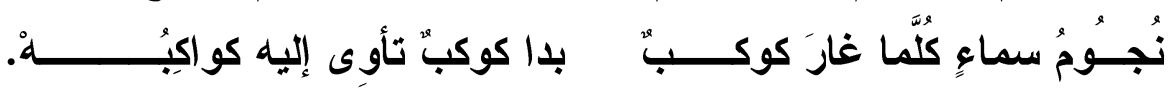

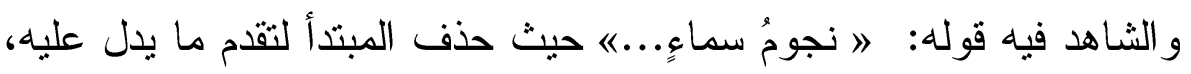
و التقدير :" هم نجوم《، و هذا الضمير عائد على لفظ 》القومه في بيت سابق لهذين البيتين وهو قوله:

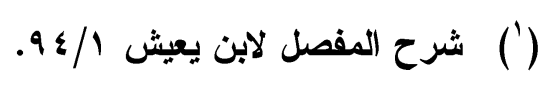

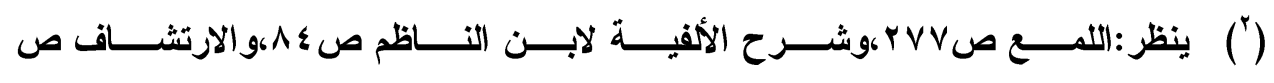

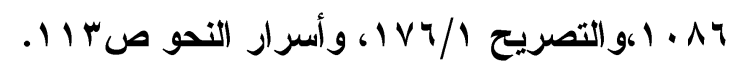

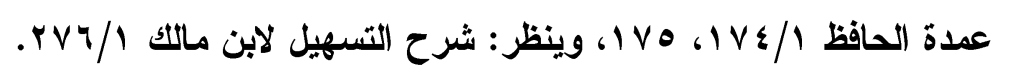

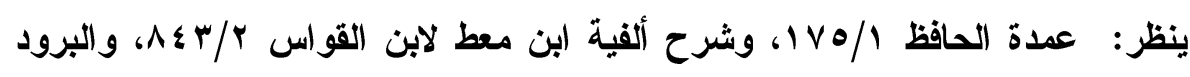




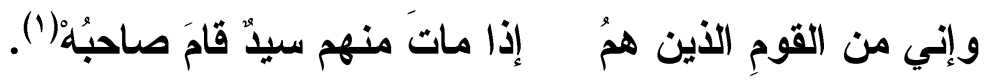

و هذا الحذف جائز.

اللغــــة

أحسابه:: الحسب ما يعده الإنسان من مفاخر آبائه.

الاجى: جمع دجيه وهي الظلمة.

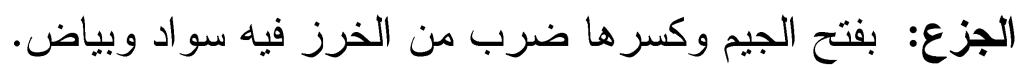

والثاقب: المضيء.

هذا... وقد استشهـ الحموي بهذا البيت على المبالغــة فــي المــديح قــال: "اويعجبني من أمتلة المبالغة في المديحه قول القائل:

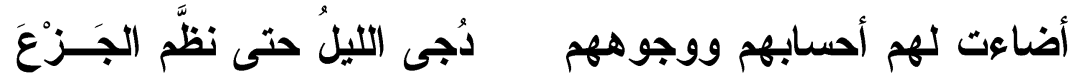

.

فالمعنى تم لما انتهى في بيته إلى قوله: إجى الليله، ولكن زاد بما هو أبلغ

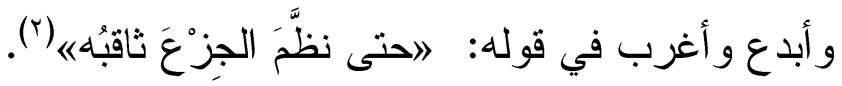

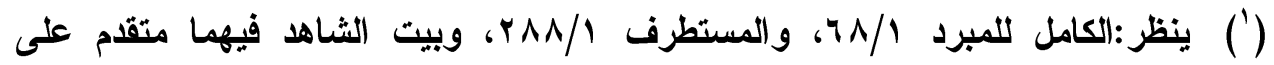

$$
\text { قوله: أضاعت لهز... ألخه. }
$$

ويكثر حذف المبتدأ في المواضع الآتية:

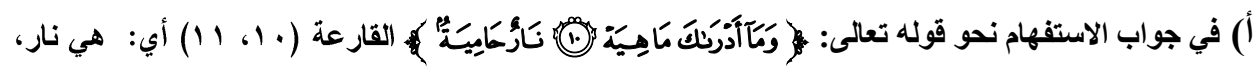

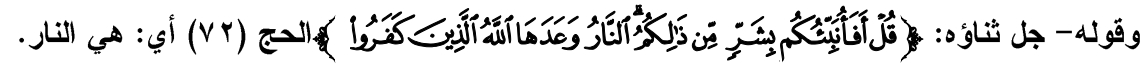

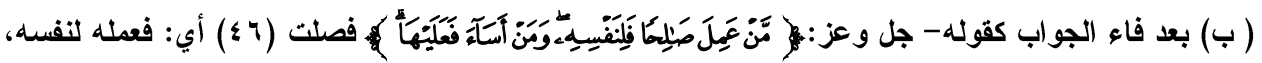

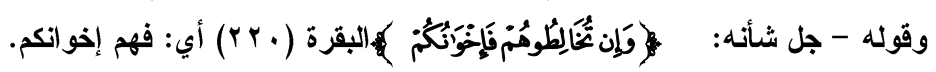

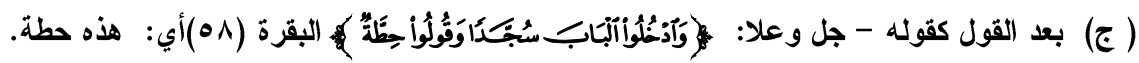

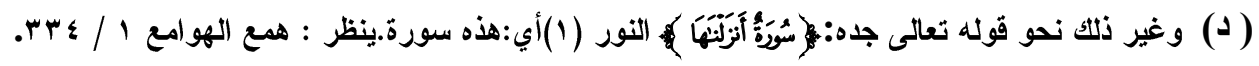

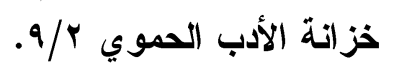




\section{مجيء اسم "لا" النافية للجنس معرفة}

\section{قال فضالة بن شريك الأسدي:}

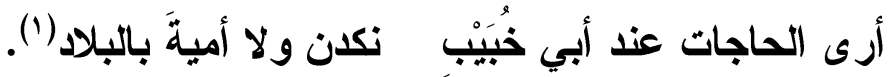

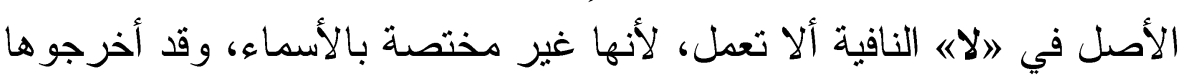

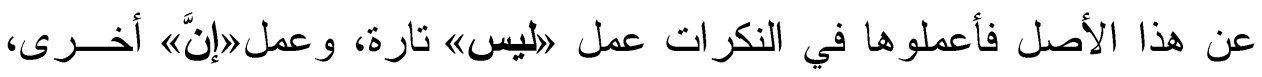

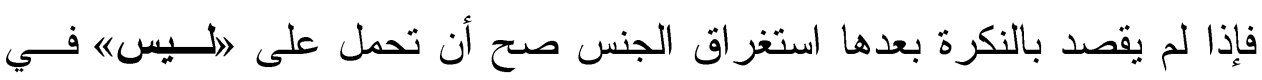

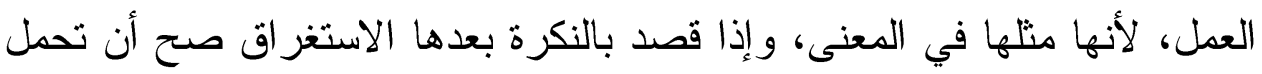

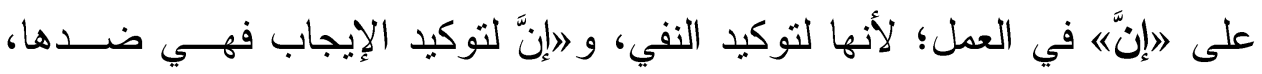
و الثيء قد يحمل على ضده كما يحمل على نظيرهها"(r).

البيت من الو اقرر ، واختلف في نسبته، فنسبه لفضالةًَ بن شريك ابنُ السبر افي في شرح

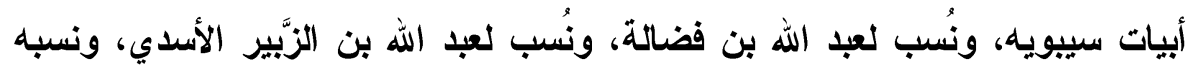

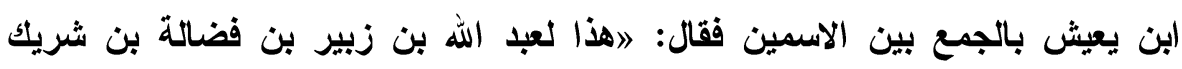

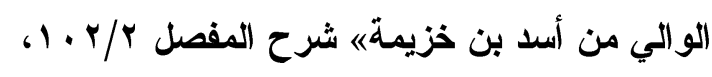

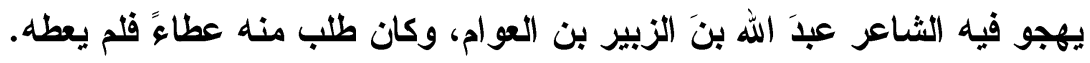

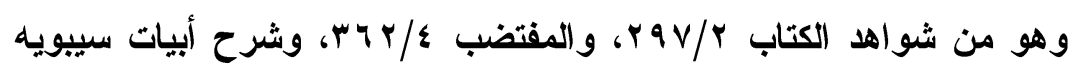

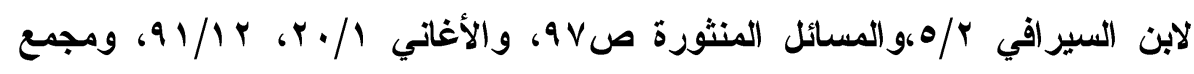

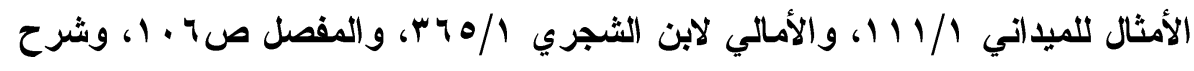

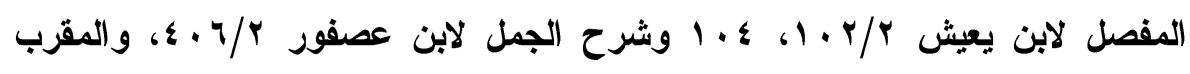

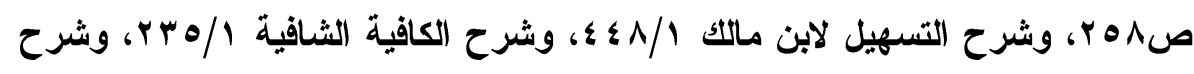

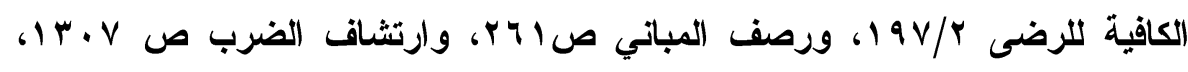

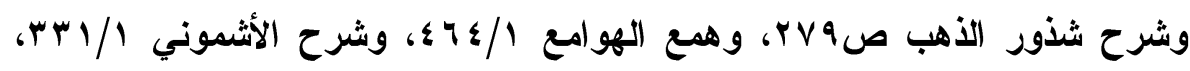


ولعملها عمل إن شروط: (') أ.

ب- أن يكون المنفي بها الجنس بأسره.

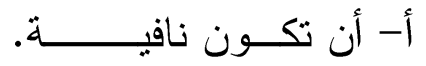

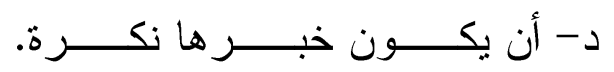
ج- أن يكـون نفيه نصنّا.

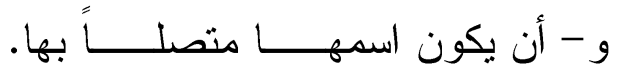
هـ- أن يكون اسمها نكرة.

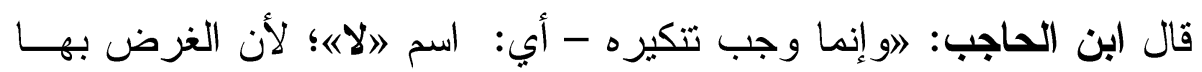

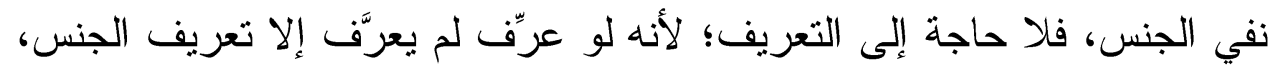

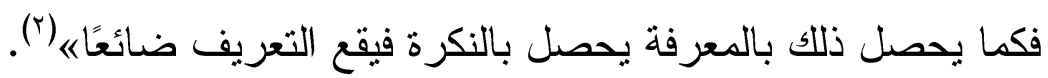

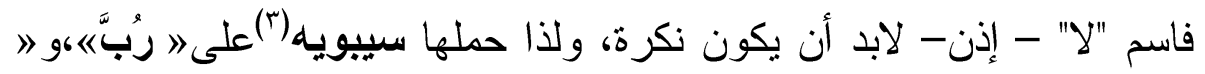

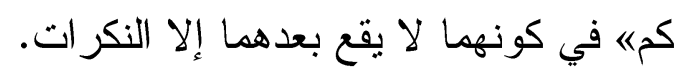

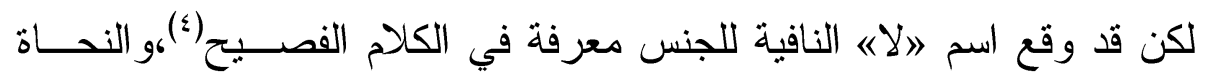

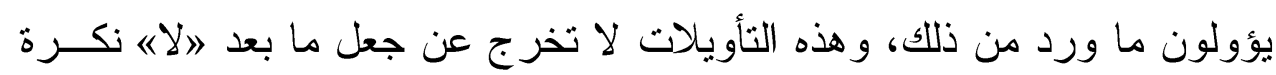

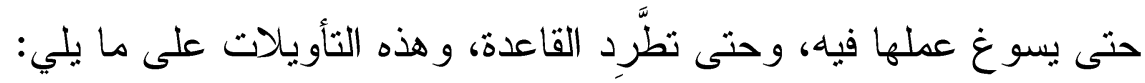

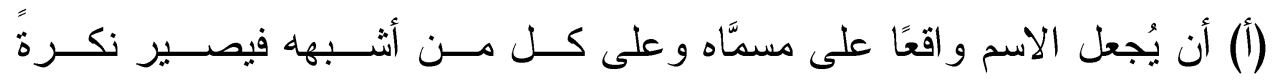

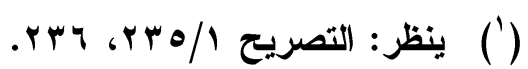

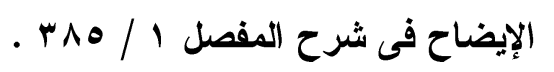

$$
\begin{aligned}
& \text { الكتاب: r/ }
\end{aligned}
$$

كقوله صلى الله عليه وسلم: (إذا هلك كسرى فلا كسرى بعدها وإذا هلك قيصر فلا

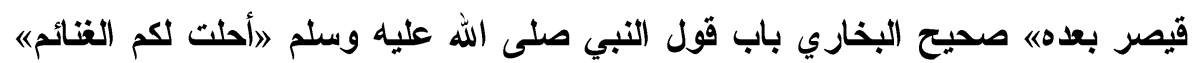

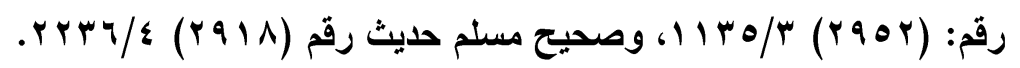

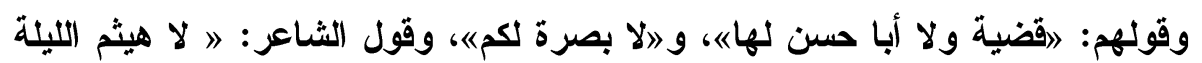
للمطى"

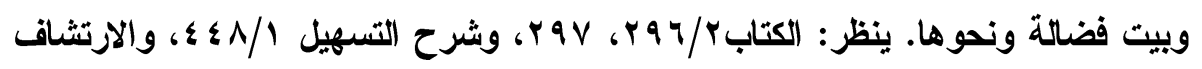

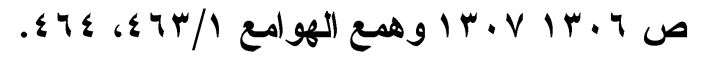


قال سيبويه في قول الثاعر:

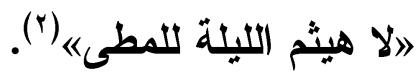

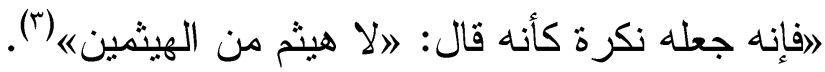

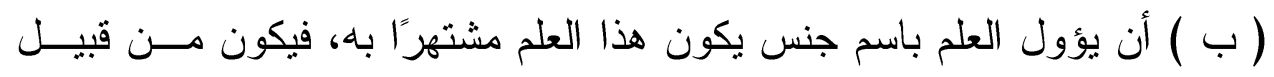

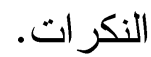

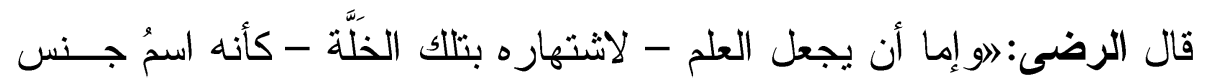

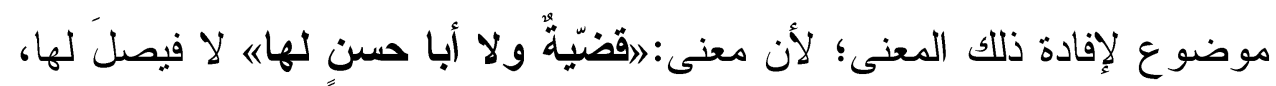

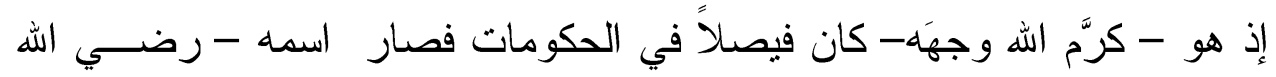
عنه- كالجنس المفيد لمعنى الفصل و القطع كلفظ الفيصل، و على هذا يمكن وصفه

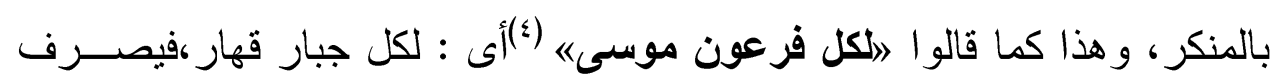
"فرعون" و "موسى" لتنكير هما بالمعنى الدذكور (0).

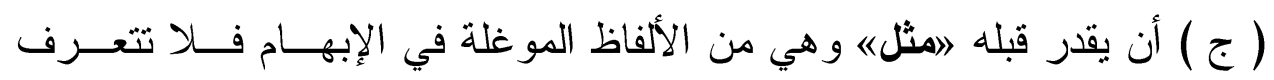

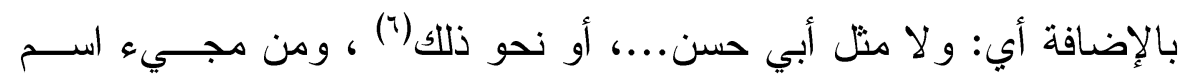

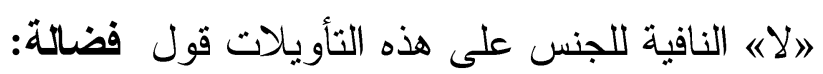

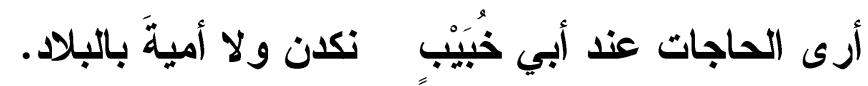

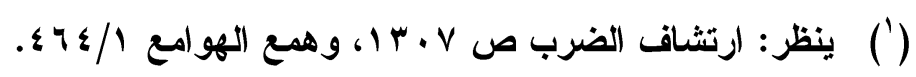

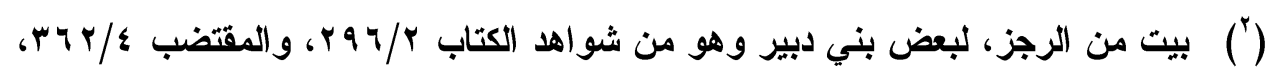

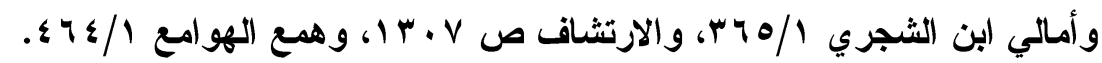

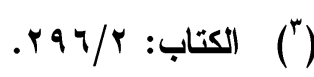

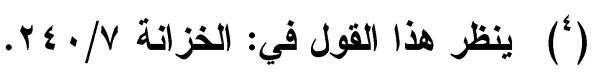

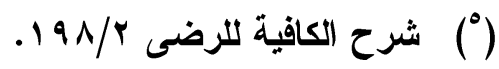

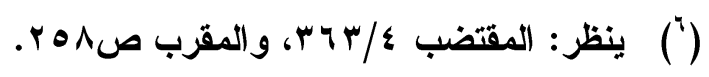




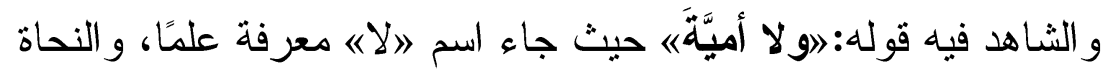
يخرجونه على أحد تأويلين:

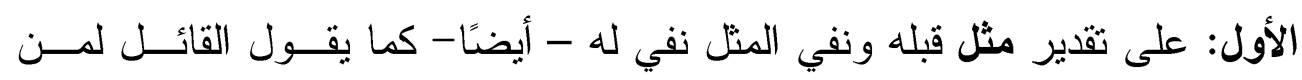

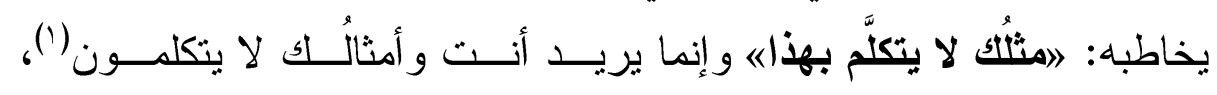

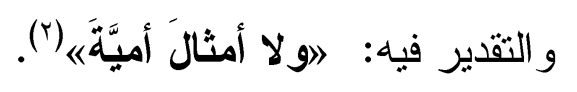

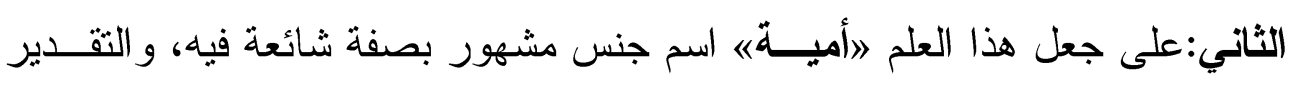

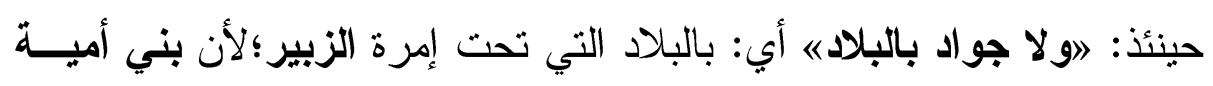

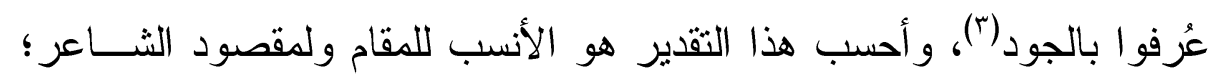
لما فيه من التعريض ببخل ابن الزبير الذي رفض إعطاءه حينما سأله.

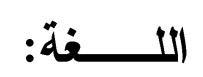
أبو خبيب، بضم الفاء وفتح الباء: كنية لعبد الله بن الزبير، وخبيـبـ هذا

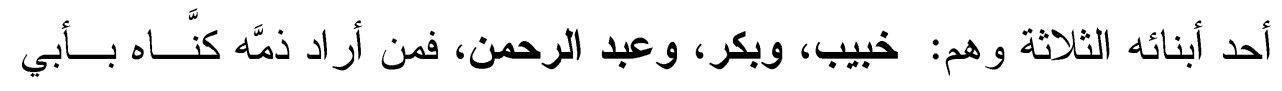
خبيب. نكلن: تعسَّرن، وأمية: أبو قبيلةٍ من قريش(๕).

$$
\begin{aligned}
& \text { (') (') ينظر : النكت في تفسير كتاب سيبويه / 1/1 • r. }
\end{aligned}
$$

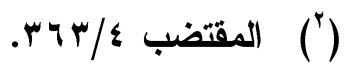

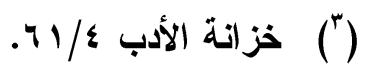

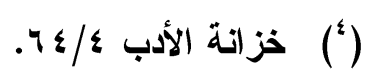




\section{الجمع بين "يا" و الميم المشددة في ضرورة الشعر}

إنِّي إذا ما حدثٌ ألمًا أقول: يا اللهم يا اللهما(1).

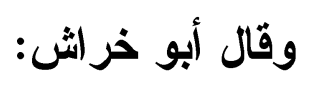

الثاهد في البيت: 》يا اللهم يا اللهماهي حيث جمع بين إيا《و الميم المشددة

و هذا شاذ؛ لما فيه من الجمع بين العوض و المعوض عنه، وقياسه أن يقول: با الله

البيت من الرجز المشطور، ونسبه بعض النحاة لأبي خراش الهذلي، لكن البغدادي -

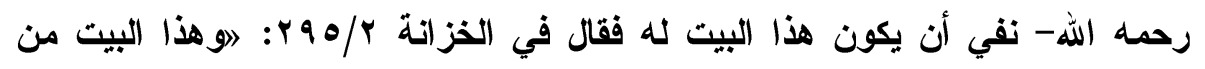

$$
\begin{aligned}
& \text { الأبيات المتداولة في كتب العربية، ولا يعرف قائله. } \\
& \text { وزعم العيني أنه لأبي خراش الهئل الهذبي. قال وقبله: }
\end{aligned}
$$

إن تغفر اللهم تغفر جما و وأي عبد للك لا ألما.

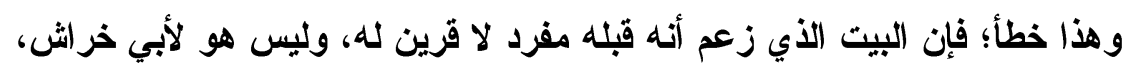

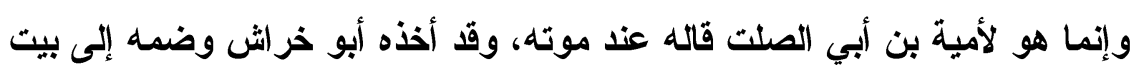
آخر وكان يقولهما، وهو يسعى بين الصفا والمروة وهما:

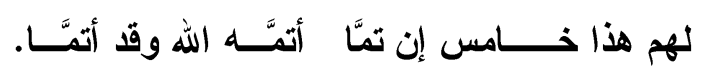

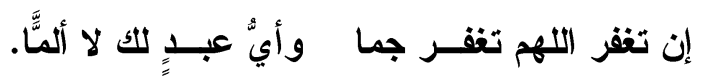

وقد تمثَّل به النبي صلى الله عليه وسلم وصار من جملة الأحاديث.

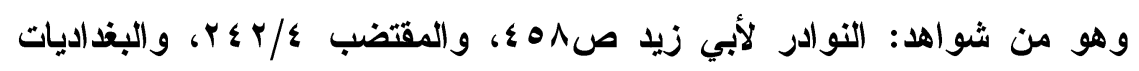

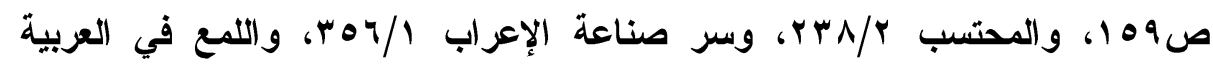

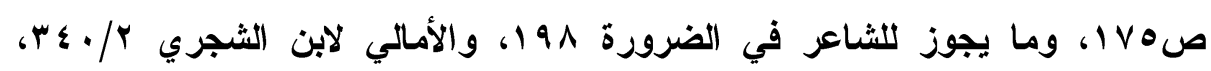

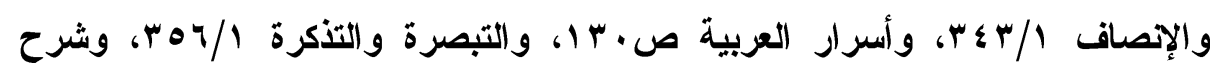

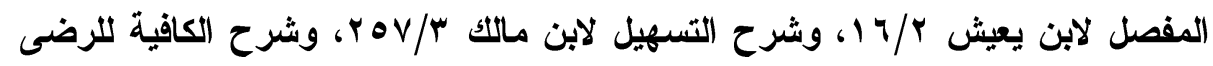

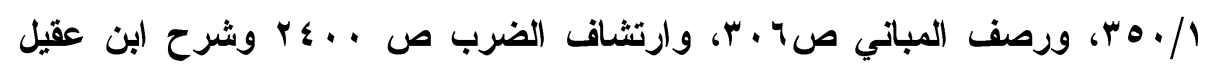

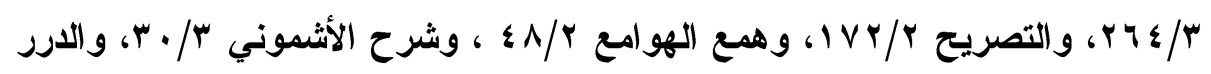

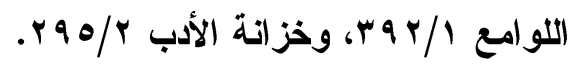




$$
\text { أو اللهم. هذا مذهب البصريين. }
$$

قال سييويه: " وقال الخليل - رحمه الله: 》اللهمهي نداء و الميم هاهنا بـدل

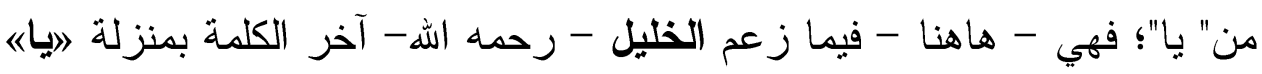

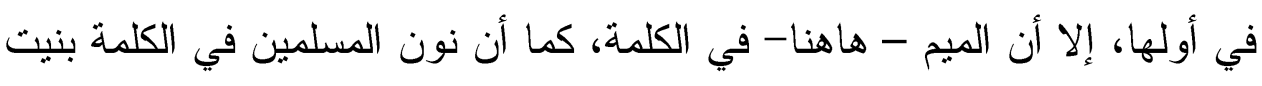

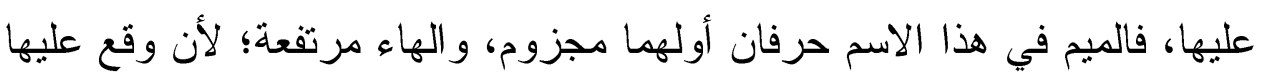

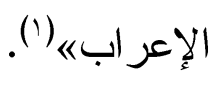

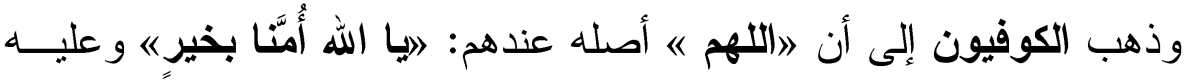

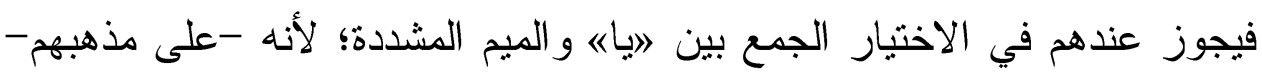

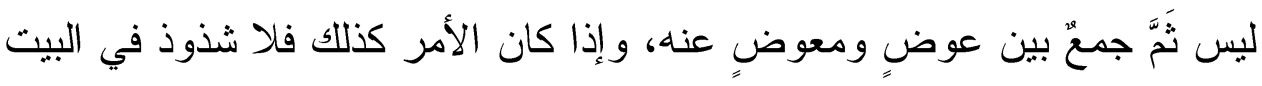
السابق .

قال الفراء: اولم نجد العرب زادت مثل هذه الميخ في النو اقص إلى مخفََّةً

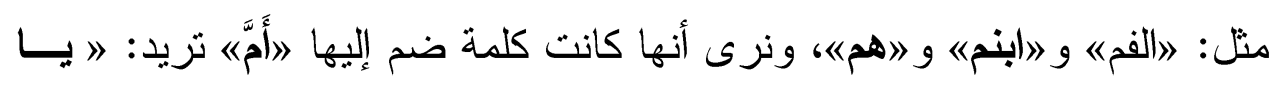

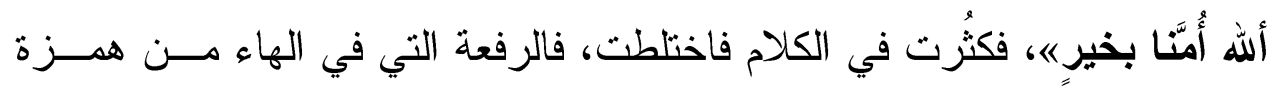

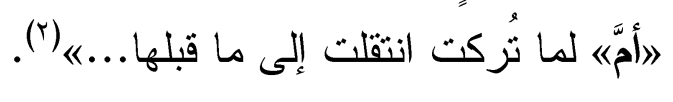
وقد ضُعِّف هذا المذهب من وجوه:

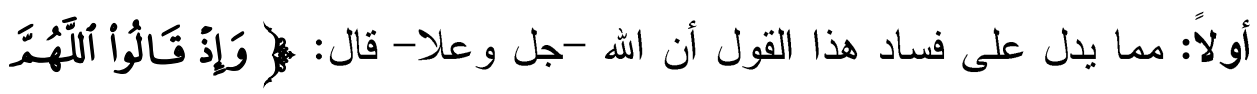

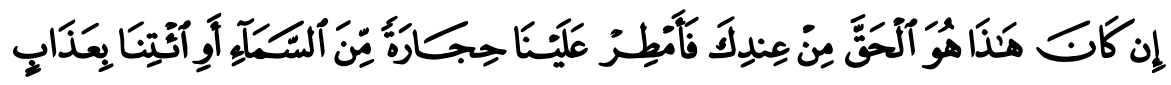

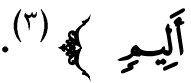

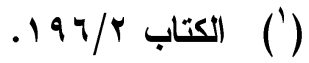

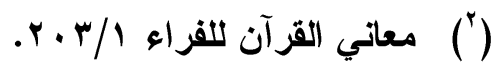

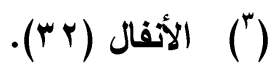




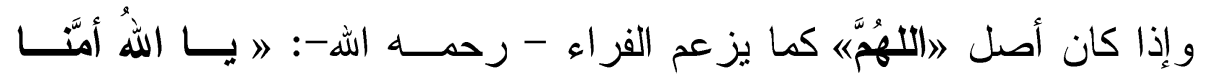

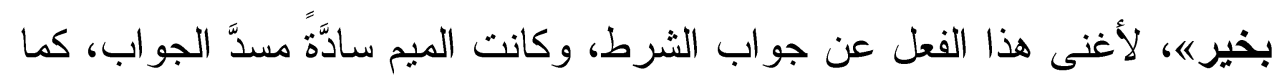

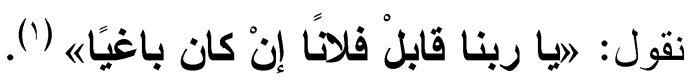

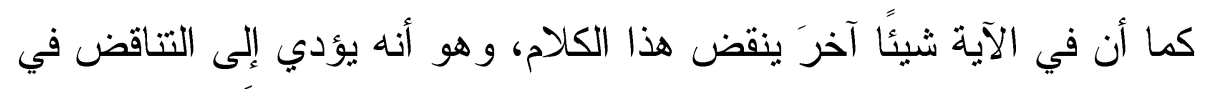

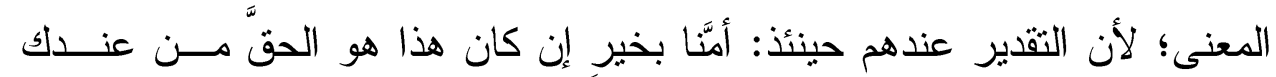

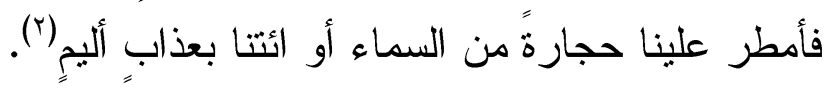

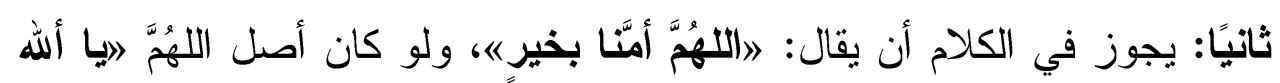

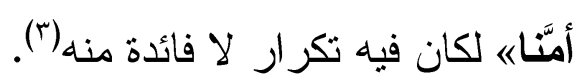

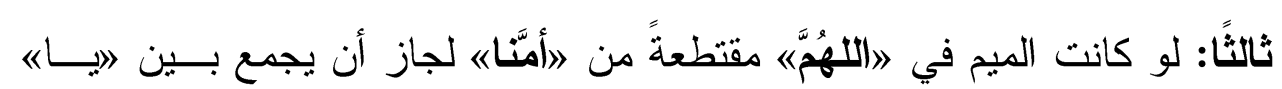

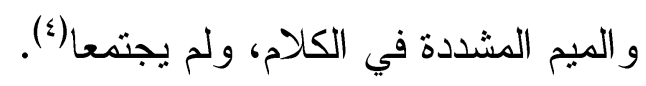

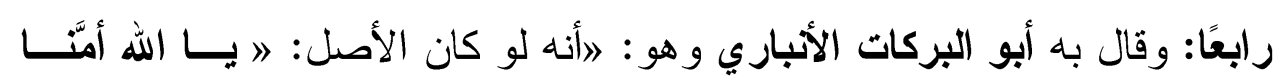

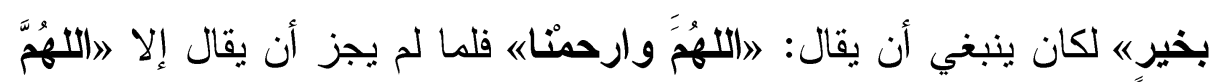

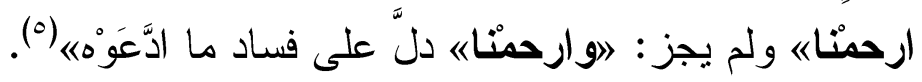

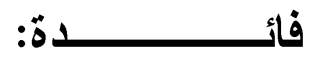

$$
\text { ترد 》اللأهُمَّه في الكلام العربي على ثلاثة أوجه: }
$$

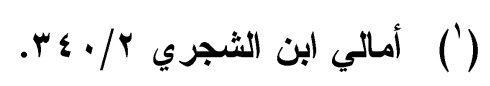

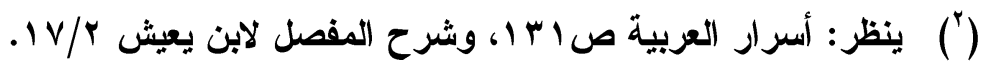

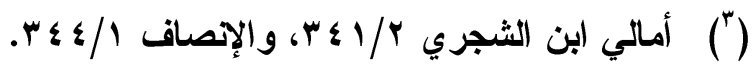

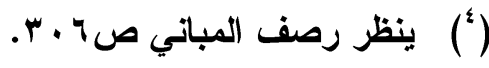

$$
\begin{aligned}
& \text { الإنصاف //\& § ז. }
\end{aligned}
$$


الثاني: أن يذكر ها المجيب تمكينًا للجو اب في ذهن السامع نحو : 》اللهُهَّ نعمه، أو :

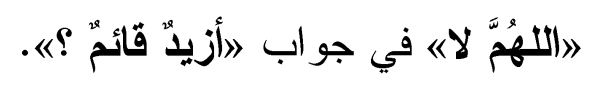

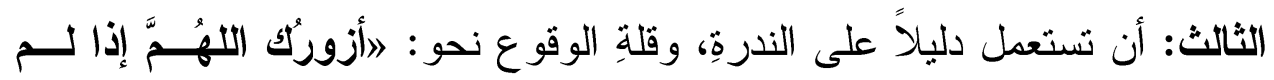

$$
\text { تََْْنَي؛؛ إذ إن الزيارة مع عدم الطلب قليلة. }
$$

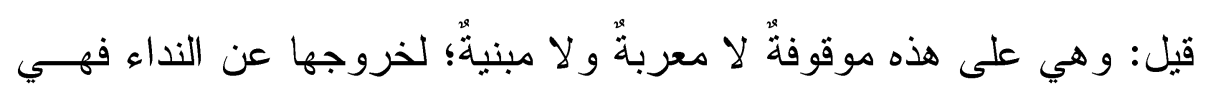

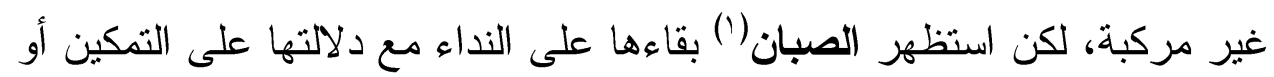

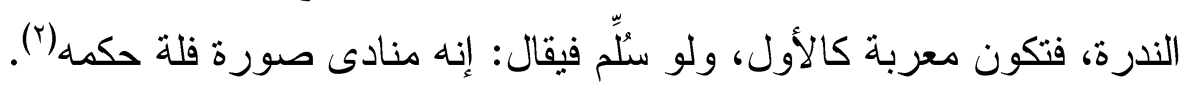

(للغة:

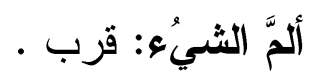

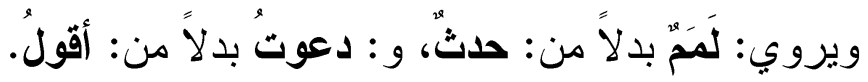

تردد الاستثناء بين كونهه متصلاً أو منقطعًا أو مفرغًا

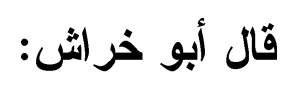

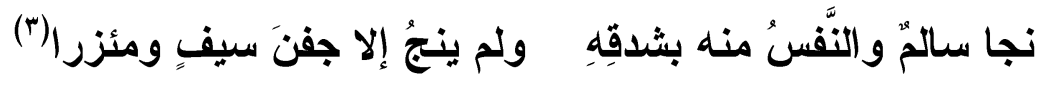

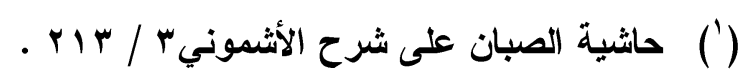

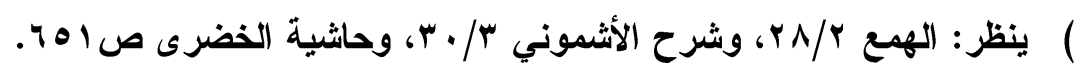

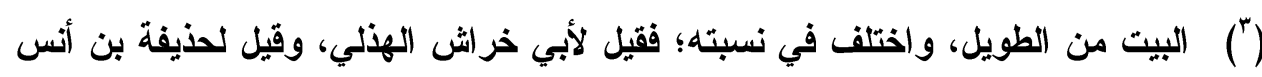

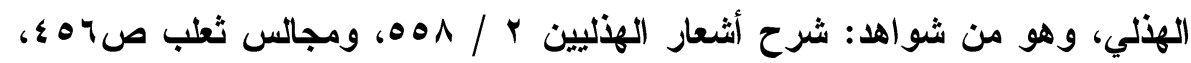

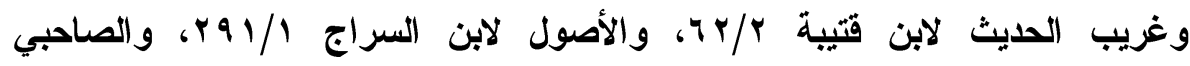

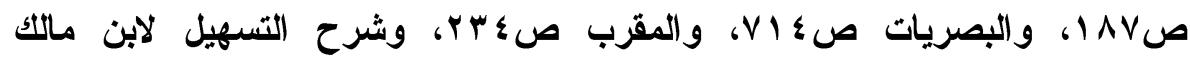

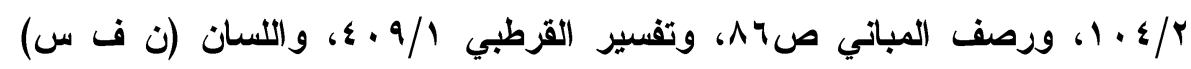

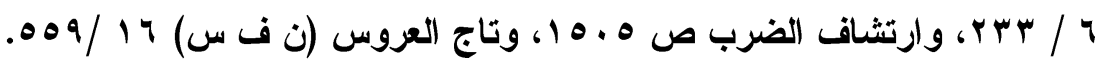


الاستثناء في قوله: الولم ينج إلا جفن سيفٍٍ... ) يحتمل أن يكون منصلاً أو

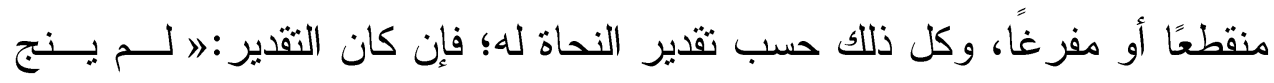

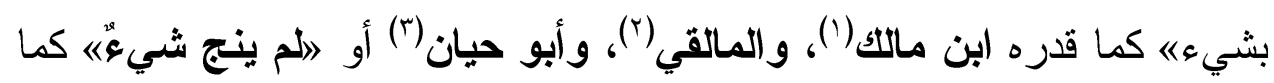

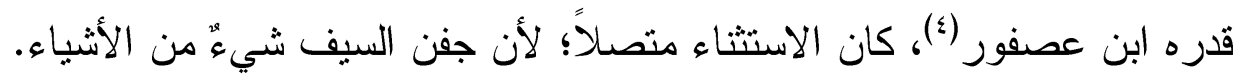

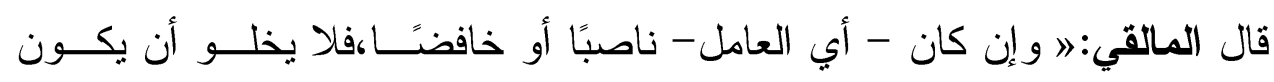
معموله محذوفًا أو لا. المان

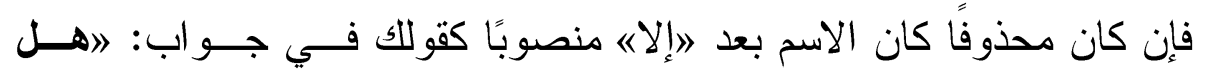

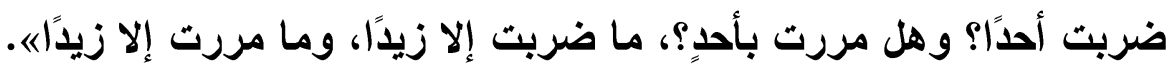

$$
\text { وأي: الولم ينج بشيء《، }
$$

وإن كان التقدير : 》ولم ينج هو - أي سالم- إلا جفنَ...) كــان الاســثناء

منقطعًا.

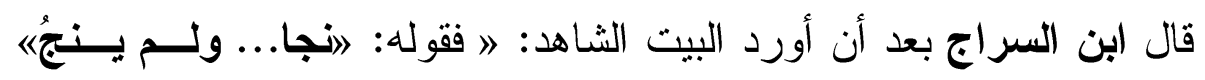

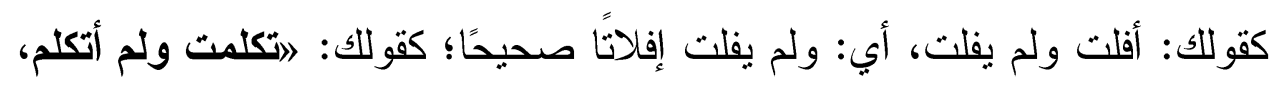

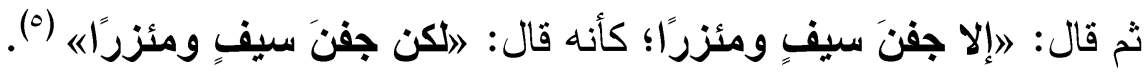
وفي اللسان: 》و انتصاب "جفنه على الاستثناء المنقطع، أي: لم ينج سالمّ إلا

$$
\begin{aligned}
& \text { (') شرح التسهيل لابن مالك ب/ع ـ 1. }
\end{aligned}
$$

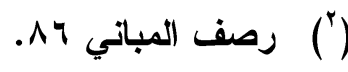

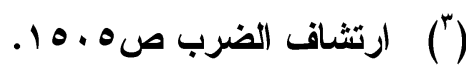

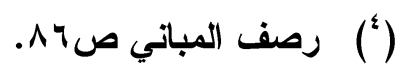

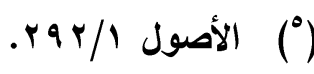


جفنَ سيفٍ، وجفن سيف منقطع منهه (')

و إن كان التقدير: اولم ينج إلا بجفن سيفٍ ومئزرٍ ثم حذف الباء ونصب،

كان الاستثناء مفرغًا على حد قوله: 》 ما مررث إلا بزيده و الجار و المجـرور - ـ

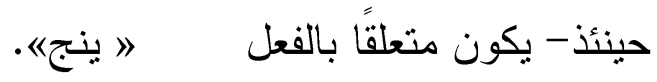

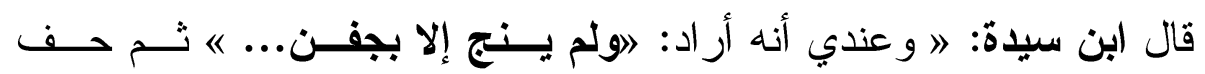

و أوصل

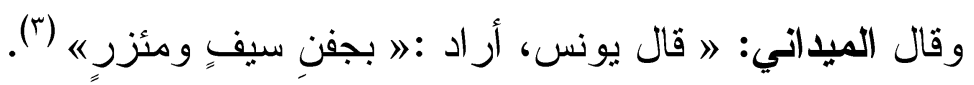

\section{اللغةة:}

الثدق: جانب الفم، وجفن السيف: غمده، والمئزر: الإزار .

يريد: أن سالمًا هذا نجا بعد أن كادت نفسه تزهق ؛فقد بلغت شدقه ولم يــنج

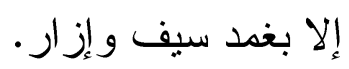

\section{خروج 》 إذاه عن الظرفية}

وقال أبو الطمحان:

وبعد غدٍ يالهُفْ نفسي من غدٍ إذا راح أصحابي ولستُ برائح(؛).

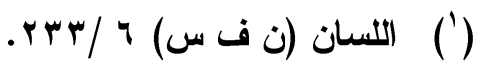

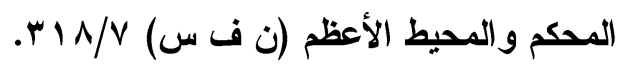

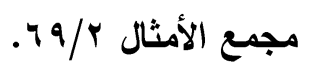

البيت من الطويل وهو لأبي الطحمان قاله حينما ذهب الطائيون لقتله قصاصنًا، وقبله:

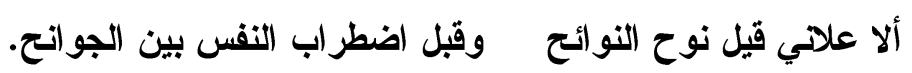

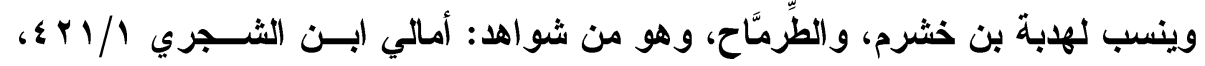

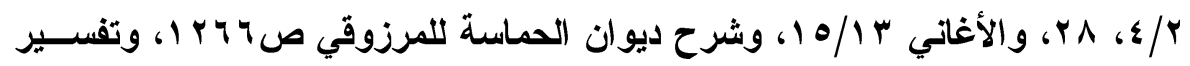


الغالب في 》إذاه إذا -غير الفجائية- أن تكون ظرفاً لما يستقبل من الزمان

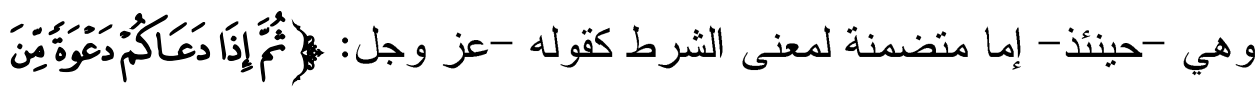

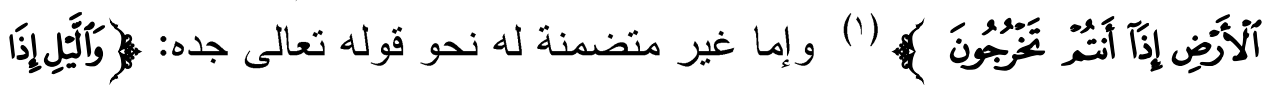

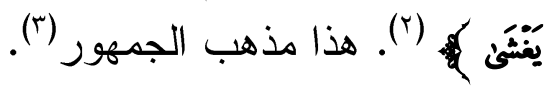

وذهب بعض النحاة() إلى أن " إذاه تخرج عن الظرفية، ومن خروجها عن

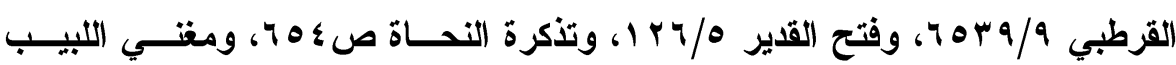

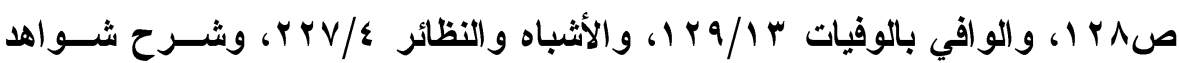
المغني / /

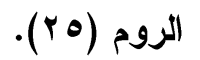

الليل (1)

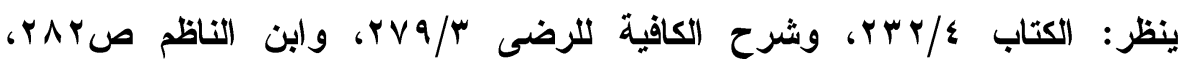

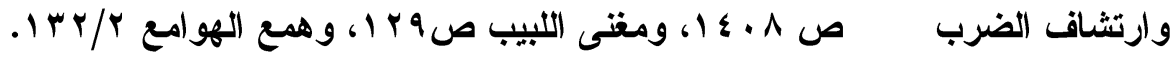
كأبي الحسن الأخفش، وابن جني، وابن الثجري، وابن مالك ـ استال أبو الحسن على الثى

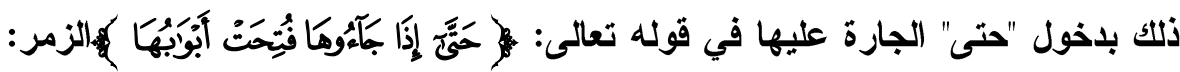

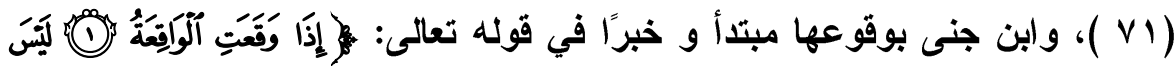

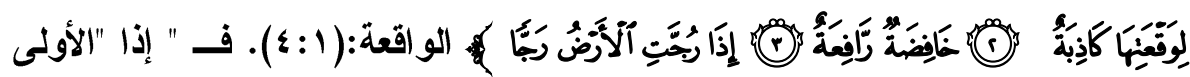

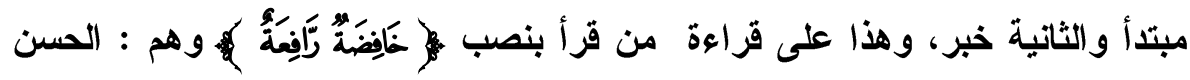
و اليزيلي والثقفي وأبو حيوة ، واستدال ابن الثجري بوقوعها بلالاً في بيت أبي الطححان، وابن مالكك بوقوعها مفعولاً به في قوله - صلى الله عليه وسلم - لعائشة

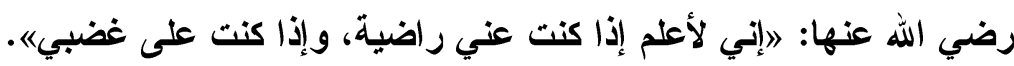

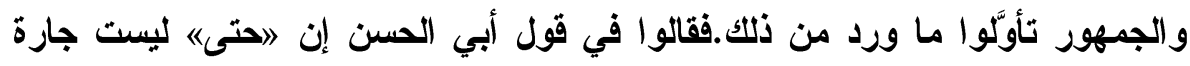

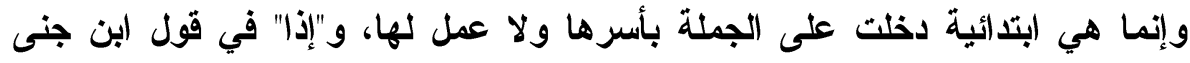

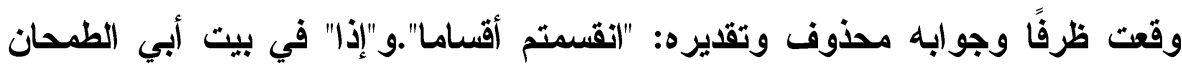


الظرفية إلى البدلية قول أبي الطمحان:

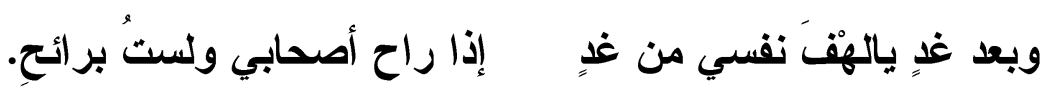

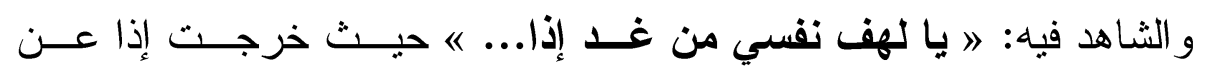

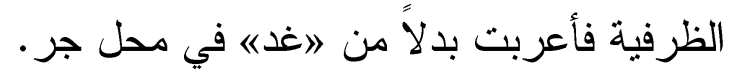

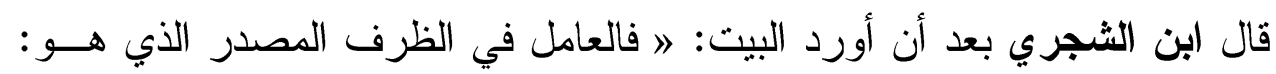

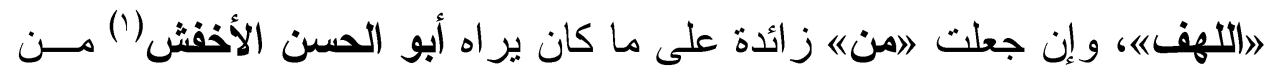

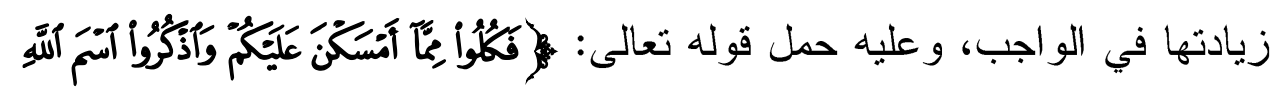

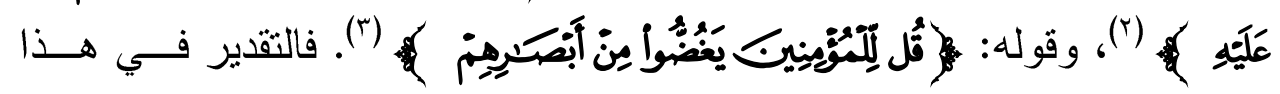
القول: 》 يا لهف نفسي غدًا فإذا قدرت هذا جعلت "إذا" بدلاً من "اغده فهذا وجهان صحيحان، ولك وجه

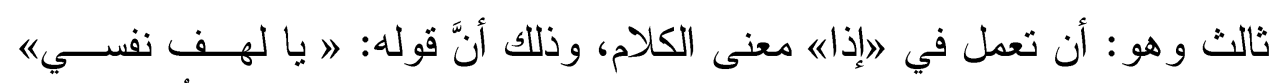

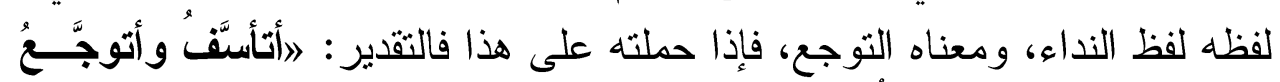
وقت رواح أصحابي وتخلّفي عنهمه (๕).

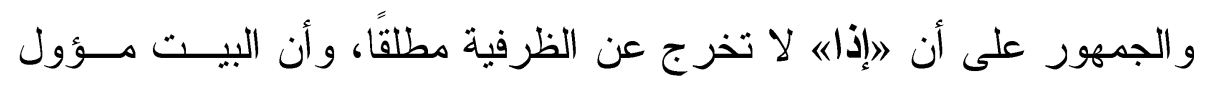

ظرف للمصدر 》لهف)،وهى في العديث الذي أورده ابن مالك ظرف لمدذوف هو

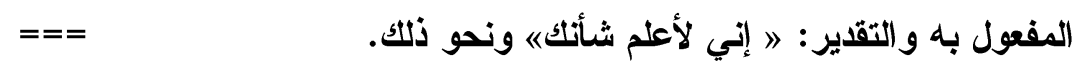

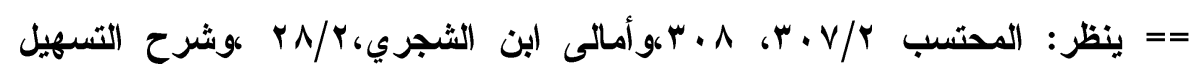

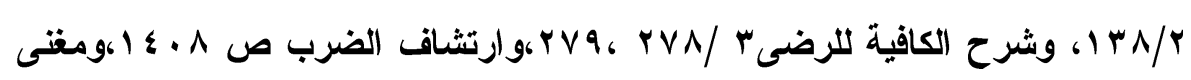

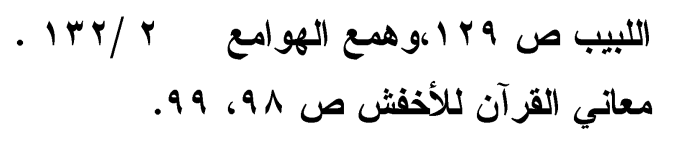

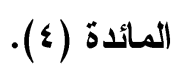

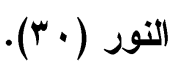

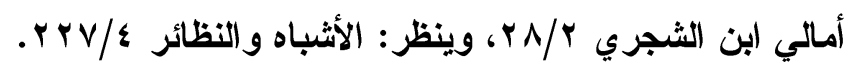


$-Y 711$

على أن "إذا" في البيت ظرف للمصدر 》 لهف《|".

وفي البيت شاهد آخر أورده ابن الشجري في أماليه، وهو: خروج النداء إلى

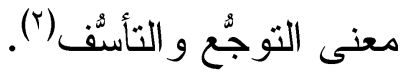

(للغة:

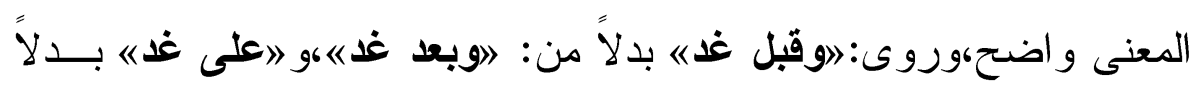

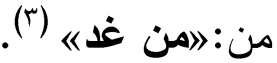

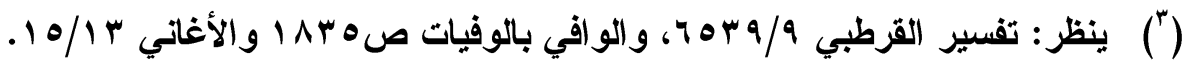




\section{حتف النعت لاليل}

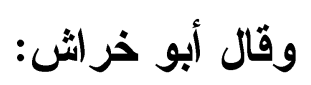

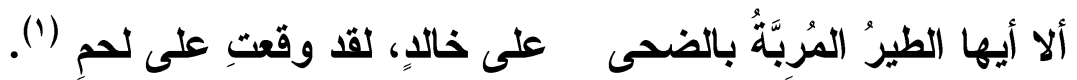

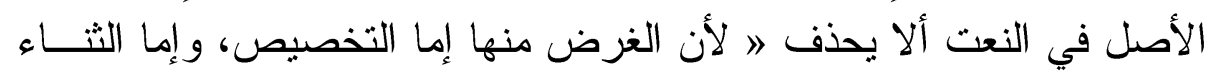

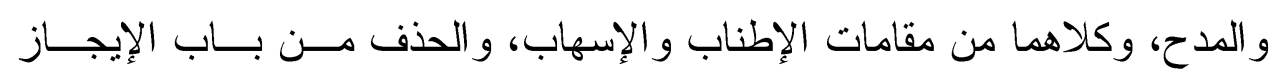
و الاختصار ، فلا يجتمعان لتدافعهاهاه (؟). بيد أن الصفة قد تحذف بقلة إذا دل عليها دليل(")، وهو نوعان: دليل مقال،

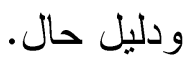

فالمقصود بالمقال: أن يتقدم لفظ في الكلام بدل على النعت المحذوف.

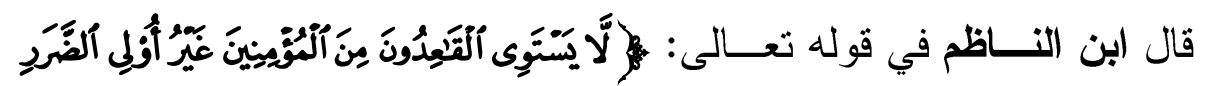

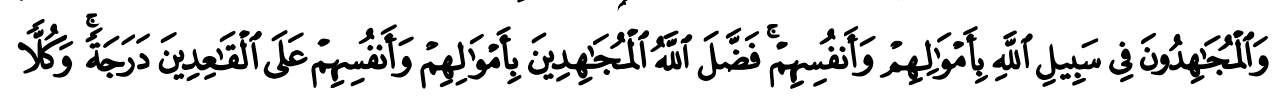

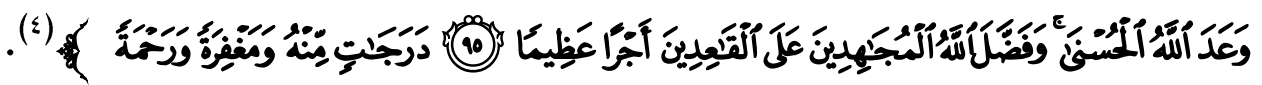

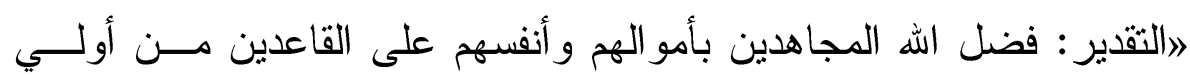

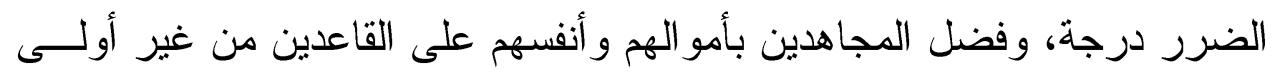

(') (البيت من الطويل، ونسب لأبي ذؤيب الهألي ،وهو من شواهد شرح أثعار الهذليين

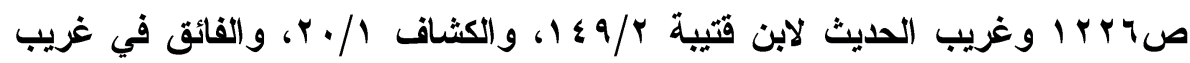

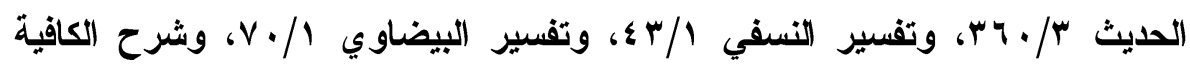

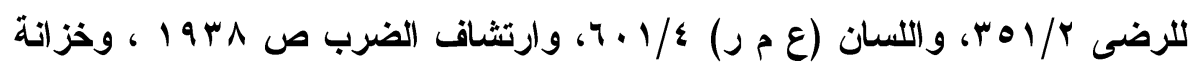

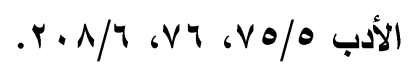

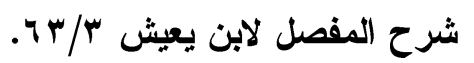

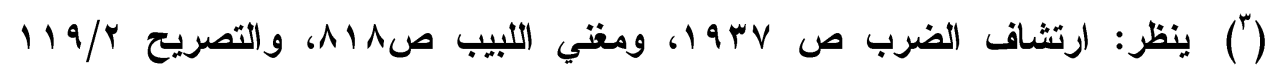

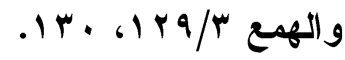

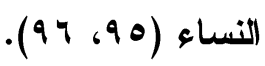




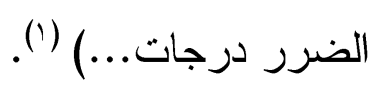

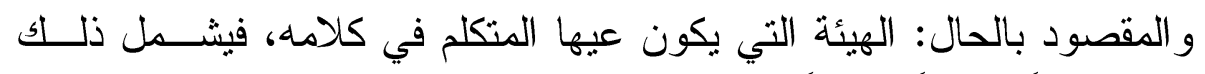

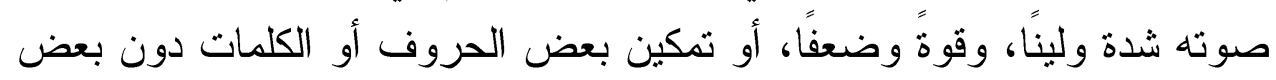

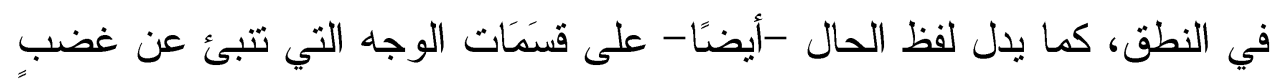

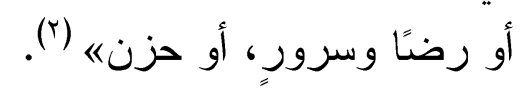

قال ابن جنى عن حذف الصفة لالالة الحال عليها: »... وذلك أن تكون في

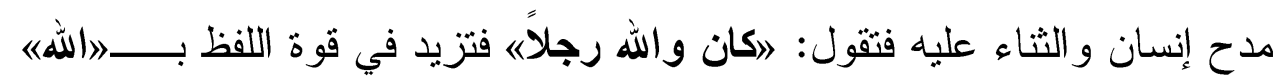

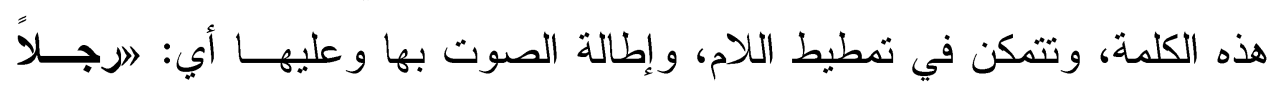

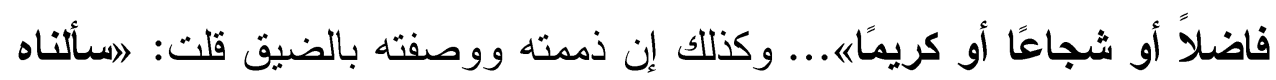

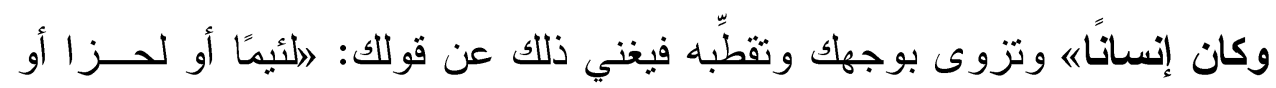

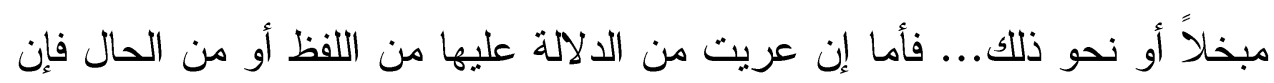

$$
\text { حذفها لا يجوز }
$$

و أرى - كذلك - أن النعت قد يحذف في مقام المدح وغيرهدمـن المقامـات

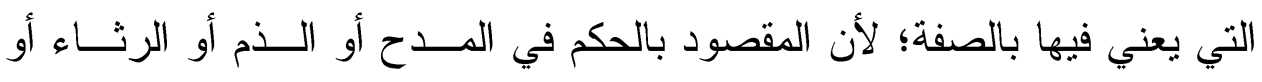

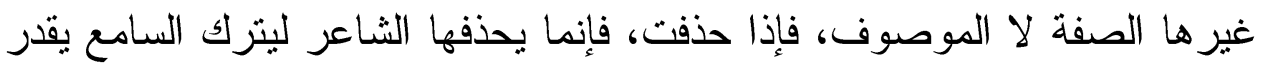

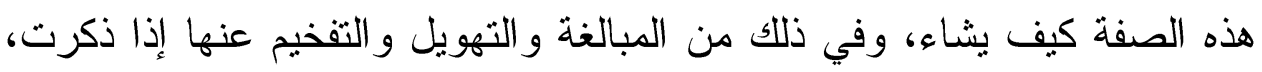

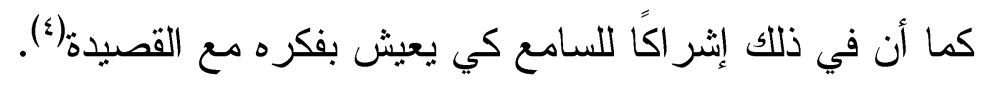

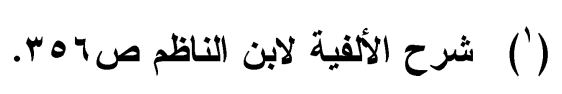

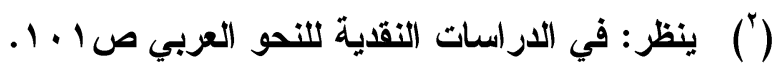

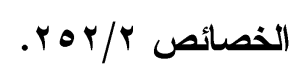

ومما يدل على ذلك قول صاحب التصريح في قول الثاعر:

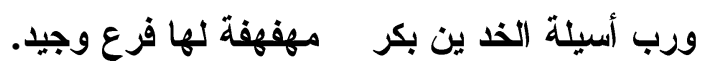

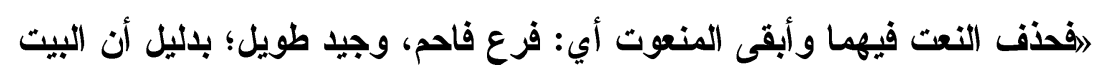


ومن هذا الباب - أعني الحذف لدلالة الحال أو السياق - قول أبي خراش:

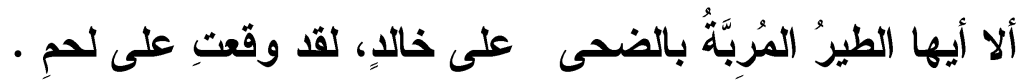

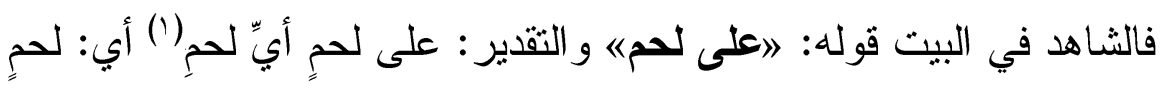

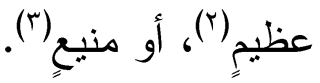

و الدليل على أن في البيت حذفًا للنعت، أن البيت ضدن أبيات يرثـي فيهــا

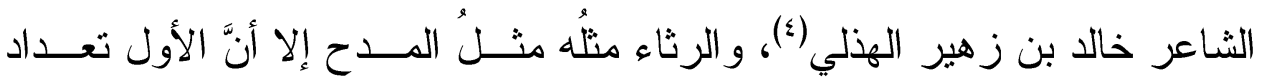

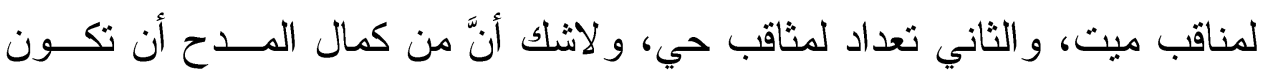
النكرة 》الحم) منعوتة على نحو يعلو معه قدرها ويعظم شأنها كما سبق.

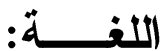

المُربَّةُ: اسم فاعل صفة الطير ، من أربَّ بالمكان إذا أقام به(ْ).

$$
\text { خالد: هو خالد بن زهير الهذلي. }
$$

وفي البيت روايات على النحو التالي (َ):

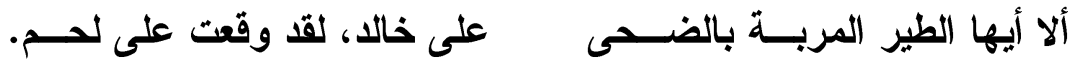

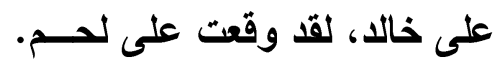

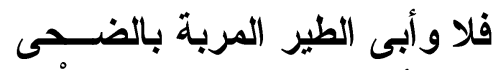

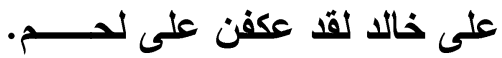

لعمر أبى الطير المربـــــة عُنْرة الطرة

للمدح، وهو لا يحصل بإثبات الفرع و الجيد مطلقين، بل بإثباتهما موصوفين بصفتين

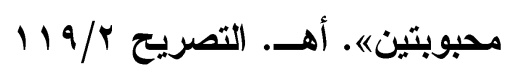

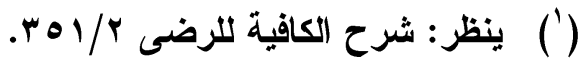

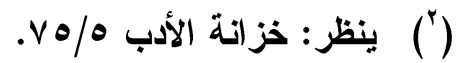

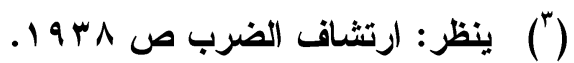

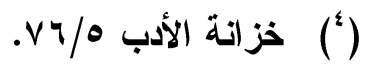

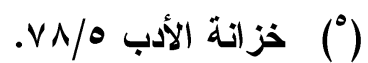

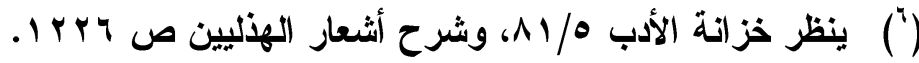


على خالد لقد وقعــت على لدـــ.

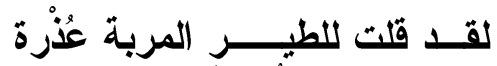

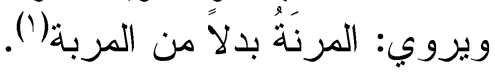

ومن حذف النعت قِّل أبي الطَُّّحَان:

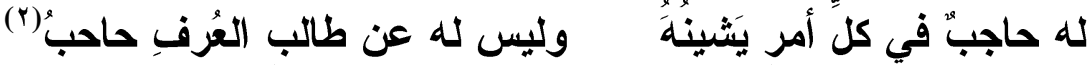

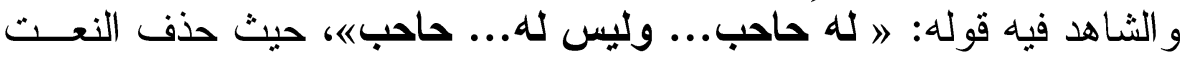

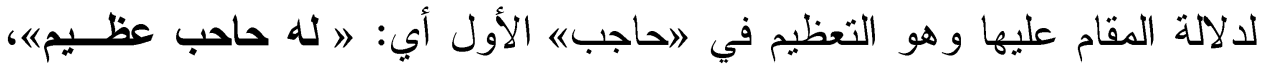

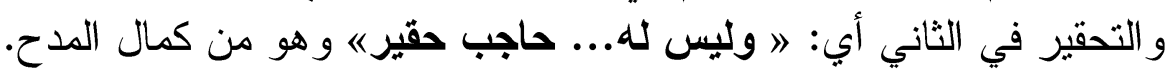

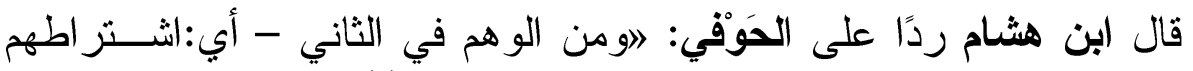

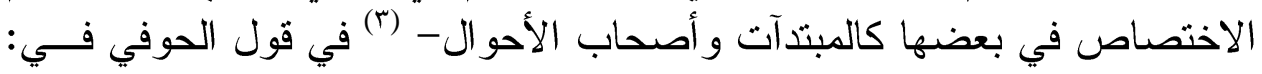

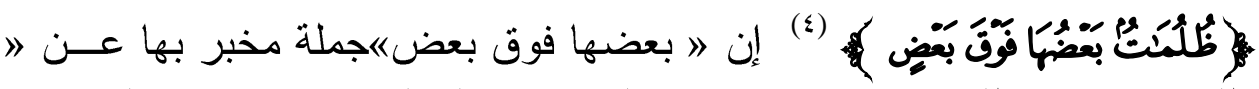

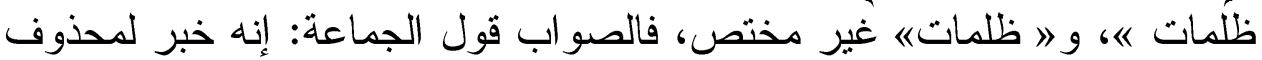
أي: " تلك ظلماتهات.

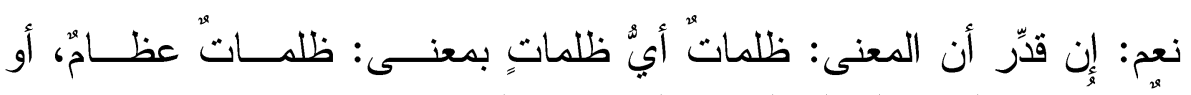
متكاثفة، وتركت الصفة لد لالة المقام عليها كما قال:

له حاجبّ.... إلخ. صحح" هاج" (0)

وقد استشهد به البلاغيون على تتكير المسند إليه لأجل التعظيم أو التحقير.

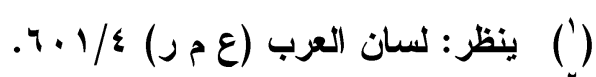

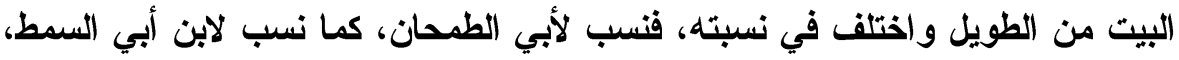

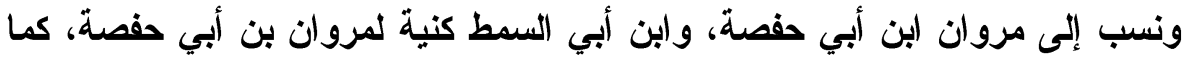

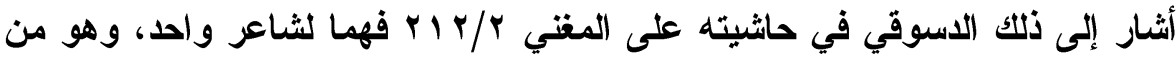

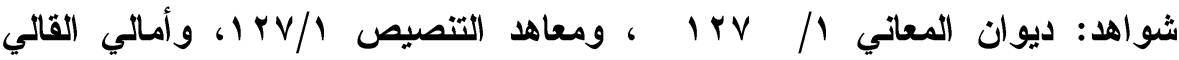

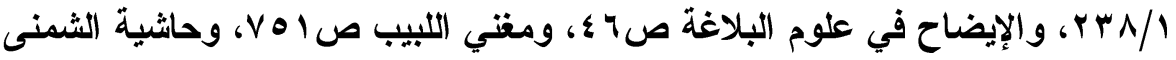

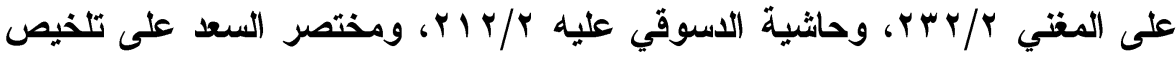

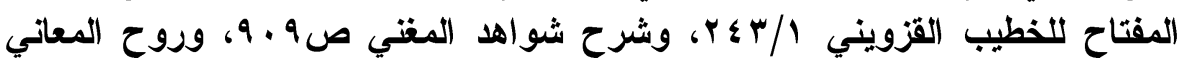

$$
\begin{aligned}
& \text { 199/1V ، 1 V V }
\end{aligned}
$$

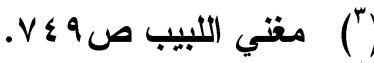

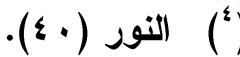

$$
\begin{aligned}
& \text { مغني اللبيب ص (4) }
\end{aligned}
$$


قال السعد: 》التعظيم أو التحقير كقوله: له حاجب... إلخ.

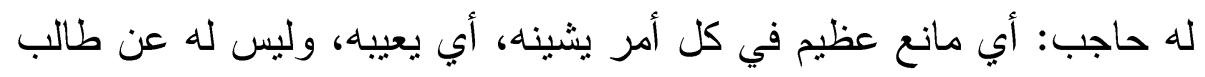

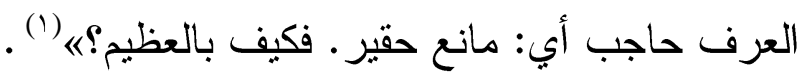

اللغنــة

حاجب: مانع، يشينه بفتح الياء: يعيبه، والعُرف بضـــم العـين: الدعـروف

و الإحسان.

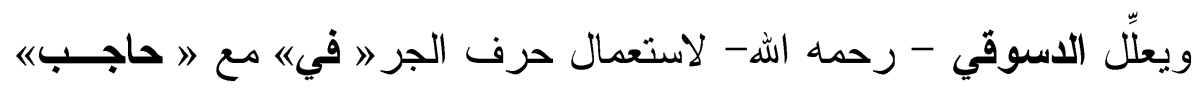

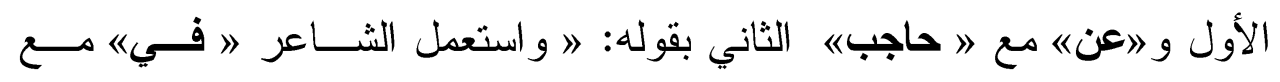

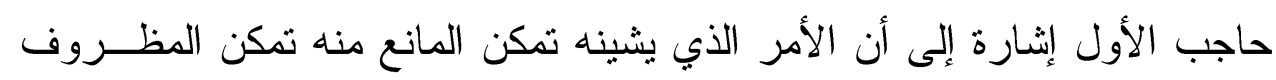

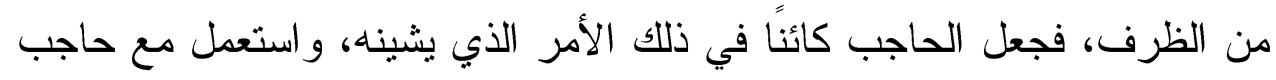

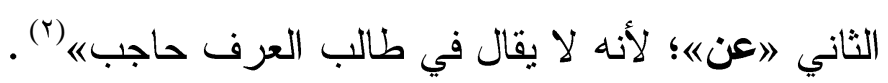

(') مختصر السعد على تلخيص المفتاح للقزويني /T/ باك، وينظر: الإيضاح في علوم

البلاغة ص 4 ـ.

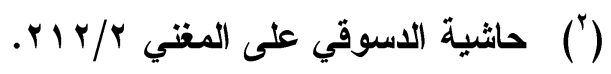




\section{تأنيث ضمير الشأن}

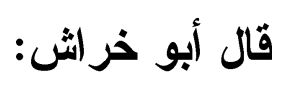

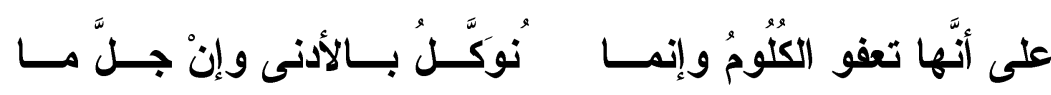

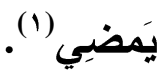

ضمير الثأن هو : ضمير غائب يأتي صدر الجملة الخبرية دالاًّ على قصـــ المتكلم استعظام السامع حديثه (r).

و البصريون يسمونه ضمير الثأن إذا كان مذكرًا، وضمير القصة إذا كسـان

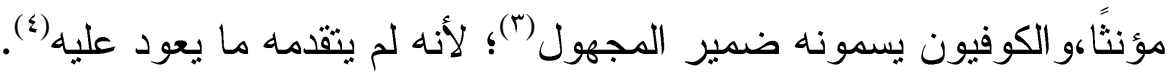

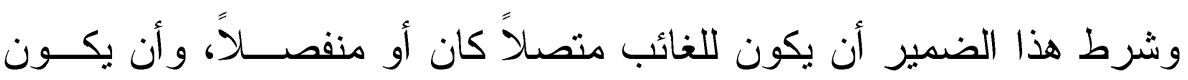

مفردًا لا مثنى و لا مجمو عًا (0)

وشرط الجملة الداخل عليها هذا الضمير أن تكون خبرية مصرحًا بجزأيهــا

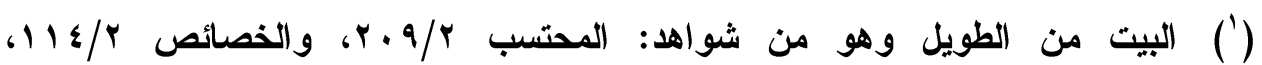

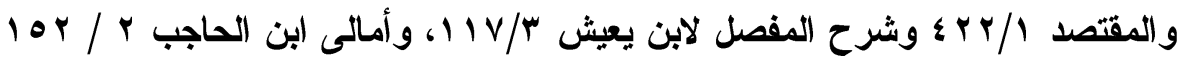

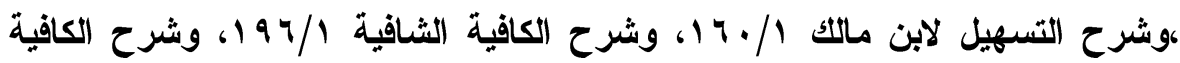

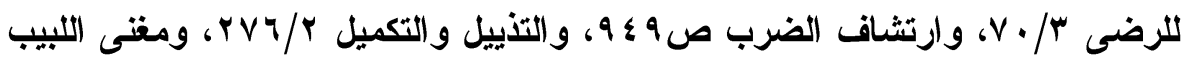

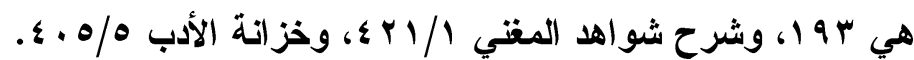

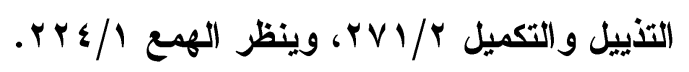

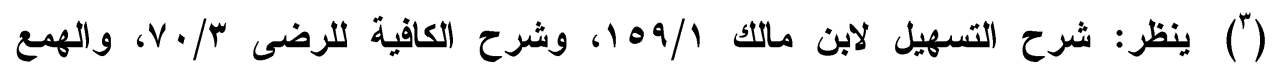

$$
\text { .rr } 4 / 1
$$

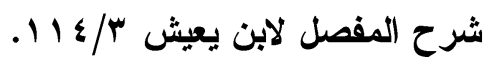

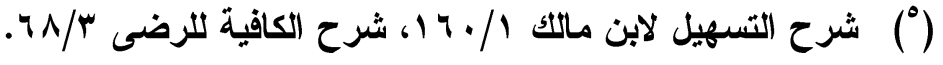




\section{خلافًا للكوفيين (') لعدم سماع ذللك(r).}

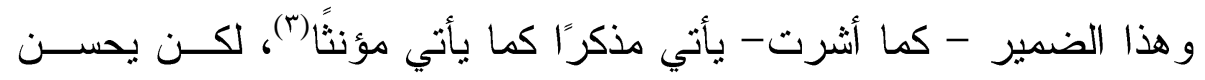

$$
\text { تأنيثه في ثلاث صور هي (؛): }
$$

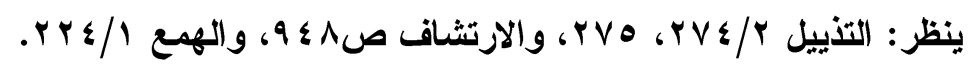

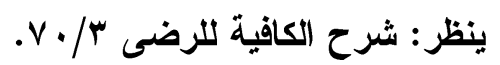

للنحاة في تأنيث هذا الضمير وتذكيره مذاهب ثلاثئة:

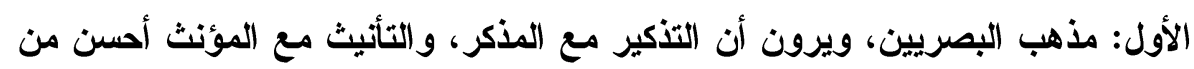

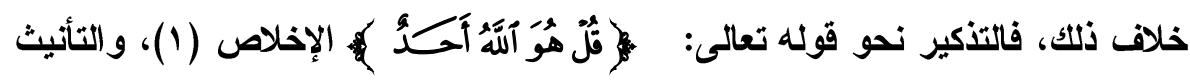

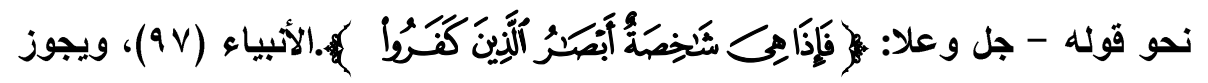

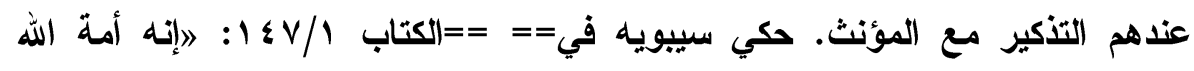

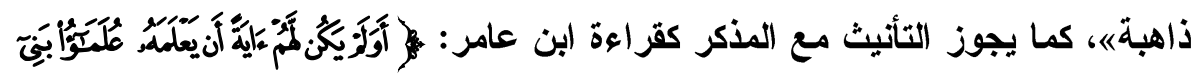

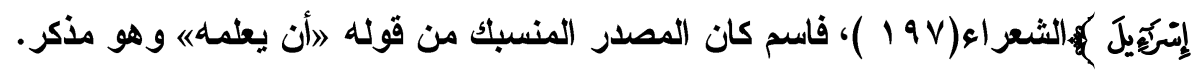

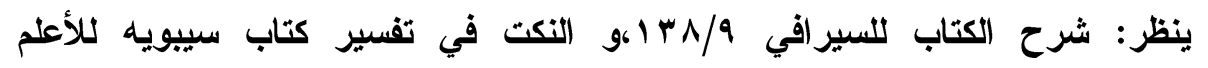

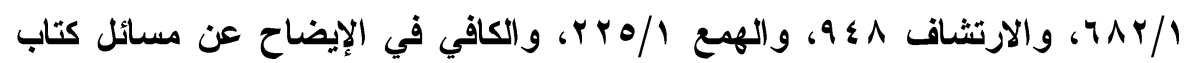

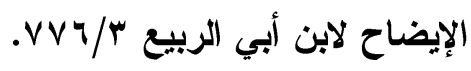
الثاني: مذهب الكوفيين، ويرون أنه يلزم التذكير إذا كان المخبر عنه مذابكرًا، والتأنيث

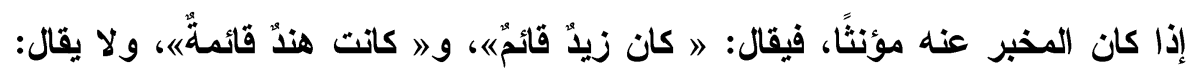

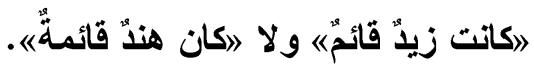

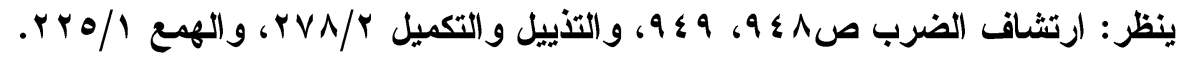

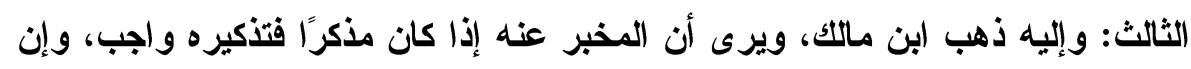

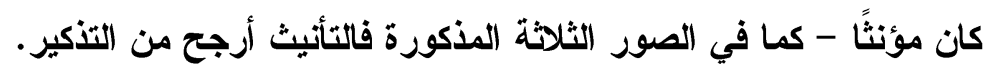

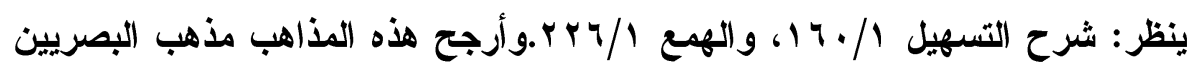
لورود السماع بذلك.

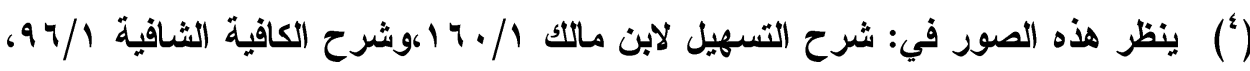


الأولى: أن يليه مؤنث نحو: 》إنها جاريتاك ذاهبتان، و إنها نساؤك ذاهباته؛. الثانية: أن يليه مذكر شبه به مؤنث نحو: 》إنها قمر جاريتكهـ.

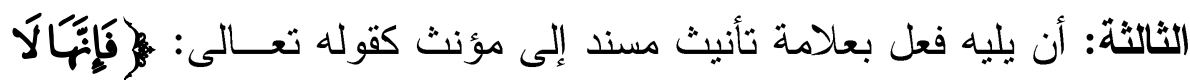

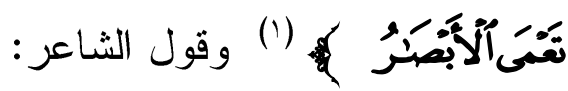

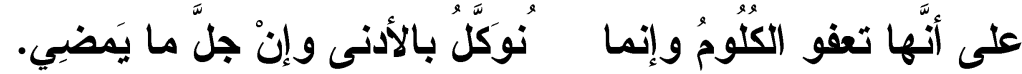
فالثناهد في البيت- وهو المقصود- قوله: 》على أنها تعفو الكلوم《 فـ 》ها《

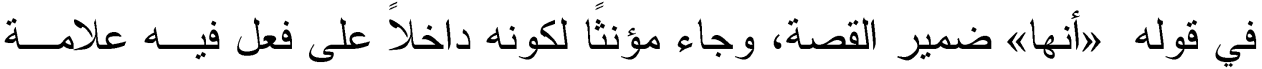

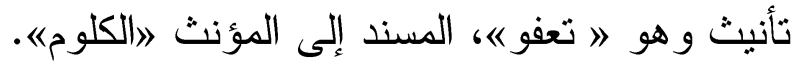

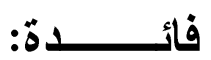

ضمير الثأن أو القصة له خصائص تميزه عن غيره من الضمائر، وهي -

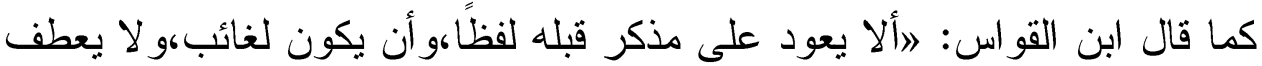

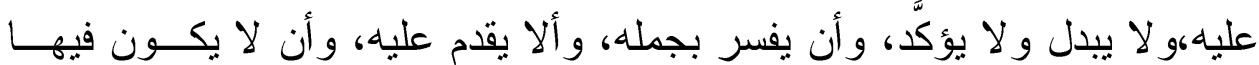

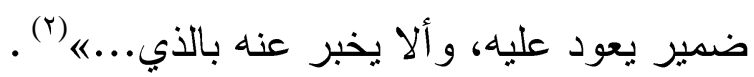
وفي البيت شاهد آخر ذكره ابن هشام في المغني على أن 》عليه في قوله:

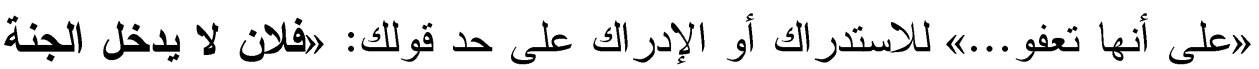
لسوء صنعه على أنه لا ييأس من رحمة الله تعالى" (r) .

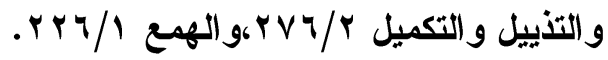

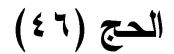

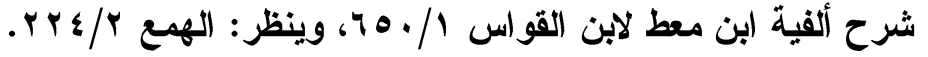


اللغــــة

تعفو: تنمحي ويذهب أثر ها، الكلوم جمع كَلْم وهو: الجُر ح، نوكــل بــروي

بالنون و الياء و التاء، ويروي بلى إنها بدلاً من على أنها.

و المعنى: إننا نحزن على الأقرب فالأقرب، وكل من مضى على رزئه زمن

نسيناه، ولو عظم خطبه، وفجعنا قسوته (1).

تذكير الفعل وتأنيثه إذا كان فاعله جمعًا سالمًا لمذكر أو مؤنث

قال عبدة بن الطبيب:

فَبَكَى بناتي شجوَهُنَّ وزوجتي و الظاعنون إليَّ ثم تصدَّعُوا (r).

هذا البيت يشير على قضية خلافية بين النحاة، وهي: تذكير الفعل وتأنيثه إذا

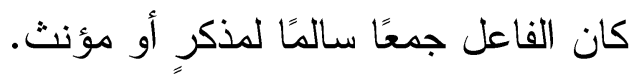

وهذه القضية فيها مذاهب ثلاثة:(r)

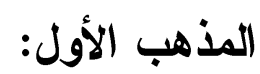

وذهب إليه جمهور النحاة من البصريين ومؤداه أنه إذا كان الفاعـل جمــعـ

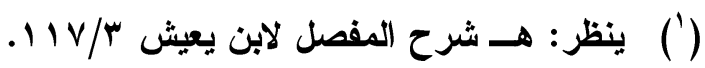

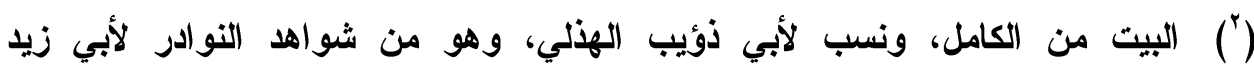

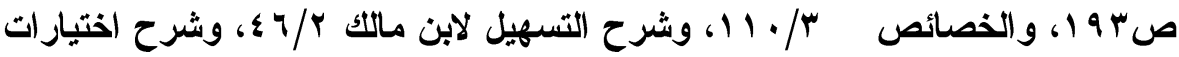

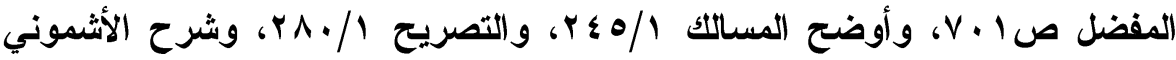

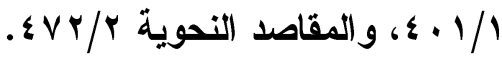

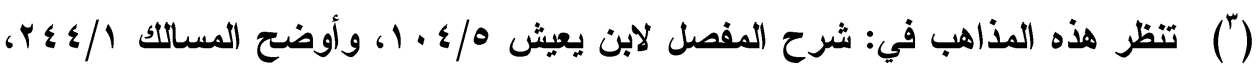

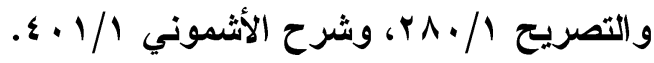


مذكر سالمًا وجب تذكير الفعل، و إذا كان جمع مؤنث سالمًا وجب تأنيث الفعـل،

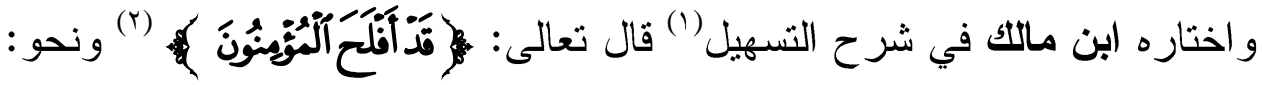

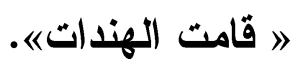

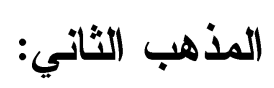

وذهب إليه الكوفيون، ويرون أنه يجوز الأمران التذكير والتأنيث في الفعـل

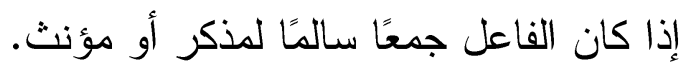

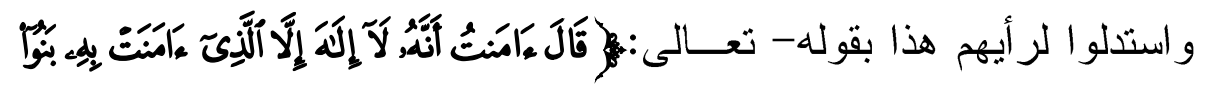

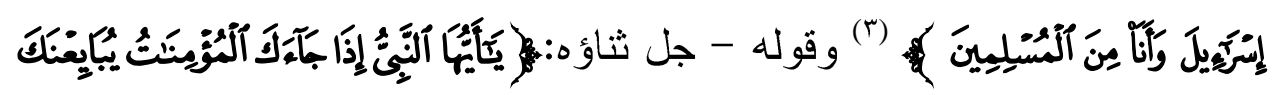

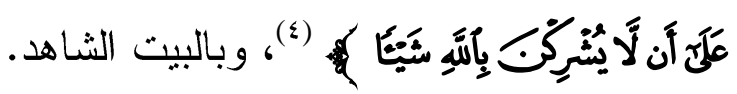

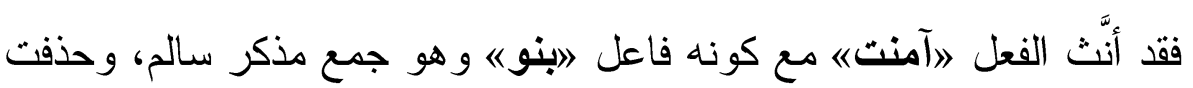

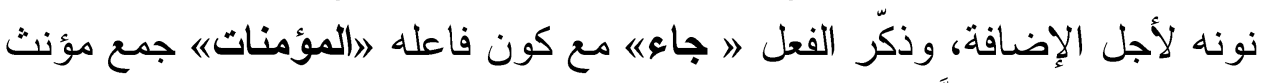

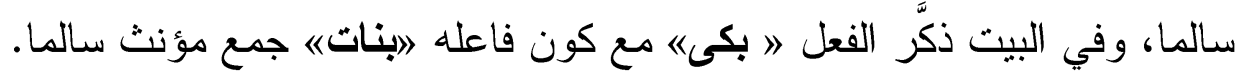

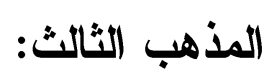

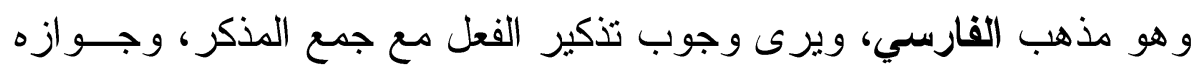

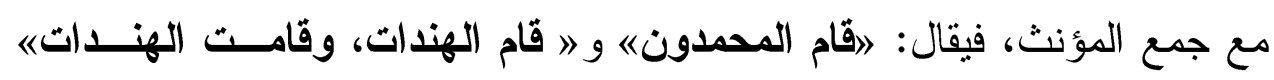

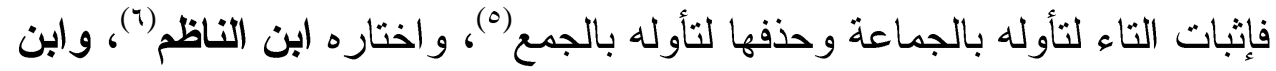

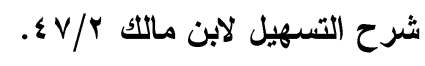

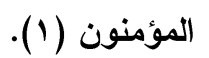

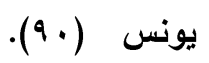

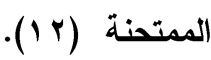

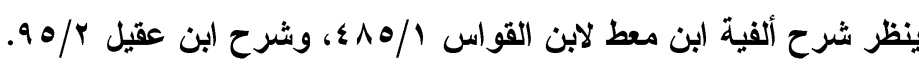


القواس (1)، وابن عقيل (r)، وهو ظاهر قول ابن مالك في الألفية)(r).

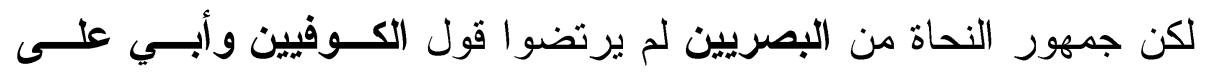

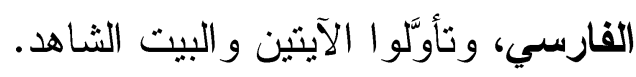

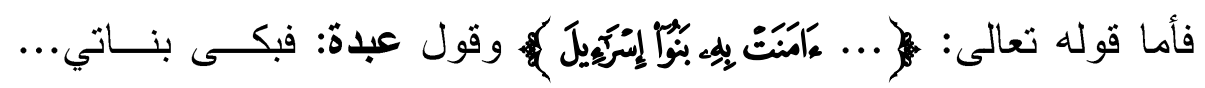

فقد أجابو ا عنهما بأن لفظ 》البنينه و 》البنات) لم يسلم فيهما بناء الواحد فهما

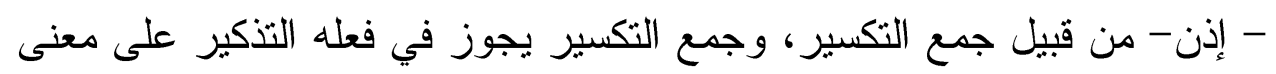
الجمع، و التأنيث على معنى جلى الجماعة.

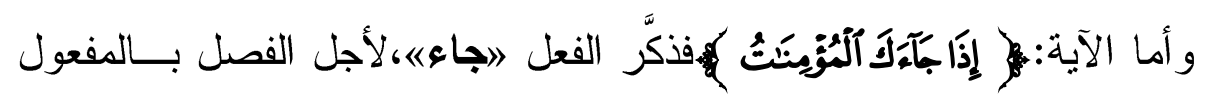

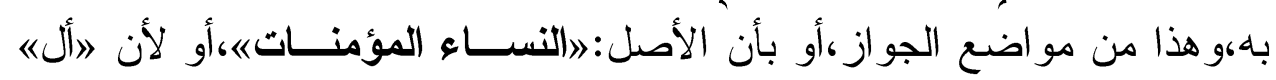

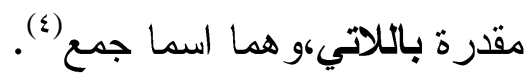

وضح مما سبق أن لفظ البنين في الآية، و البنات، في البيت الثاهد من قبيل

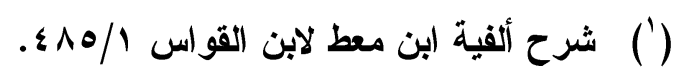

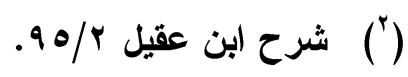

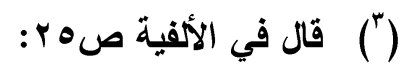

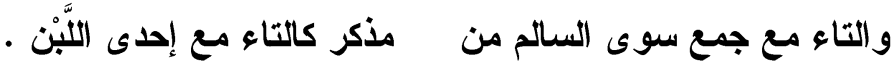

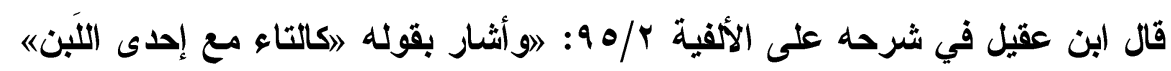

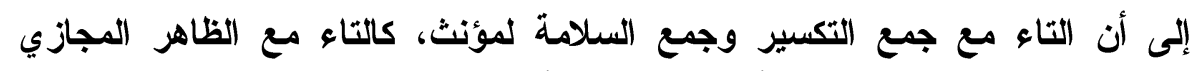

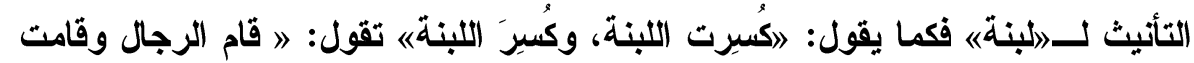
الرجاله وكنلك باقي ما تقدمه أهـ.

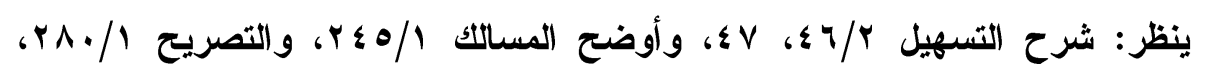

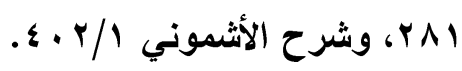




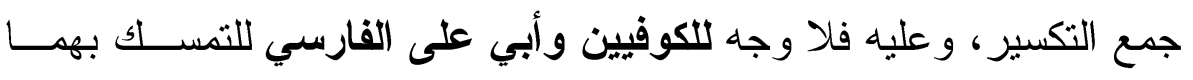
فليسا محلاً للخلاف.

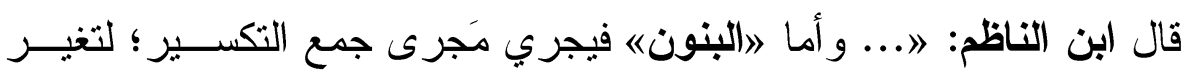

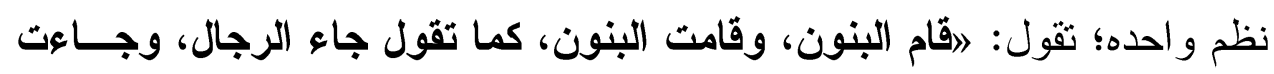

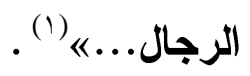

وقال الثشاطبي: اومحل الخلاف في تصحيح الجمعين إذا لم يحصل تغييــر

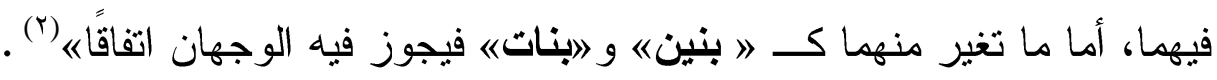
وفي البيت شاهد آخر وهو قوله: " فبكى بناتي شجوهنه حيث جاء قوله: "

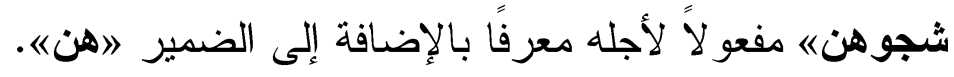

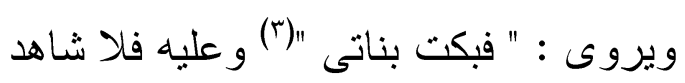

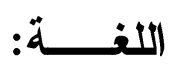

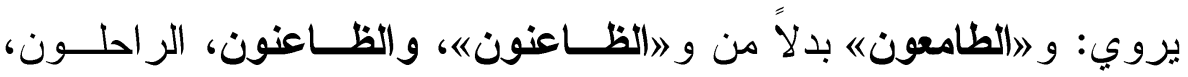

$$
\text { و الثجو: الحزن وتصدعوا: تفرقو ا. }
$$

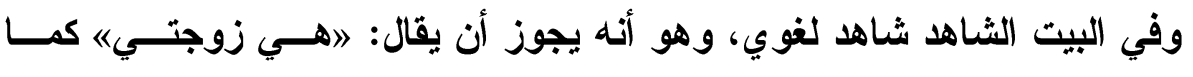

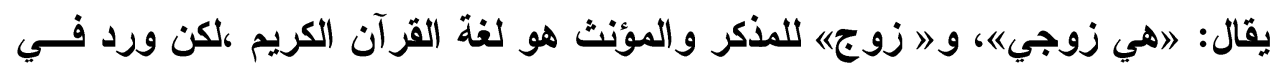

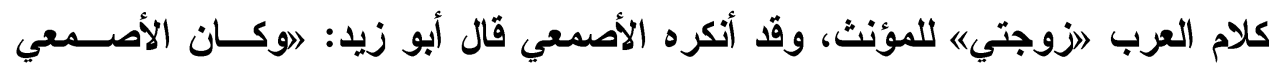

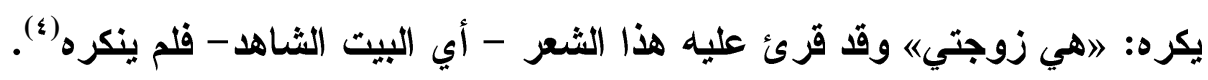

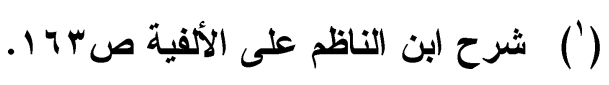

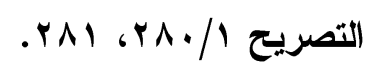

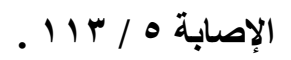

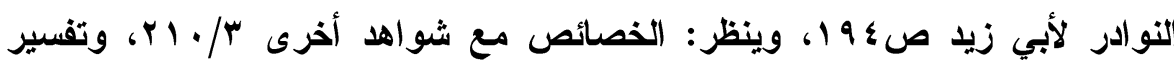




\section{ثبوت مؤنت »أهل) في الفصيح}

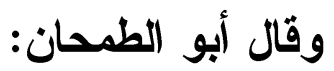

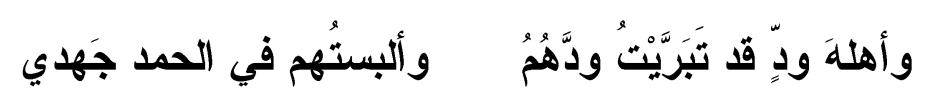

ونائلي (1).

هذا البيت استشهد به على أن 》أهلاً) يؤنث بالتاء فى قوله: 》وأهلة ودِّ). قال الرضى: اوأهله/ في الأصل اسم دخله معنى الوصف، فقيل في جمعـهـ

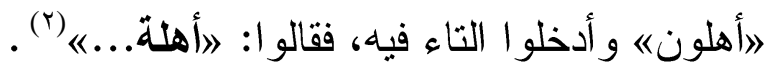
و هذا البيت فيه رد على الخليل الذي زعم أنه لا يقال: 》أهلةه) (r).

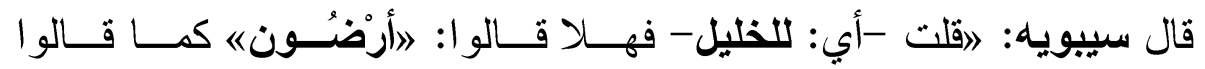

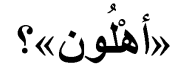

قال: إنها لما كانت تدخلها التاء أر ادوا أن يجمعو ها بــالو واو والنــون كمــــا

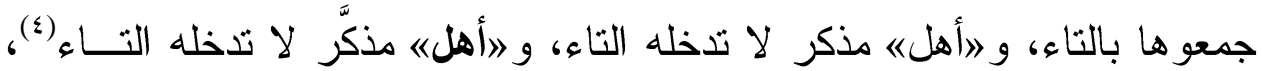

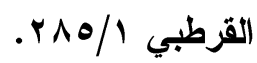

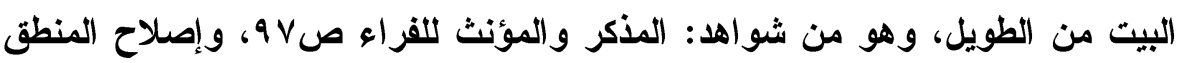

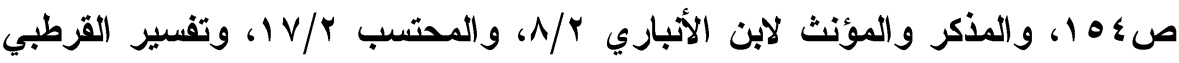

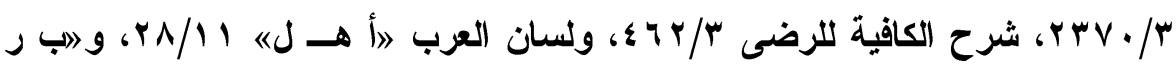

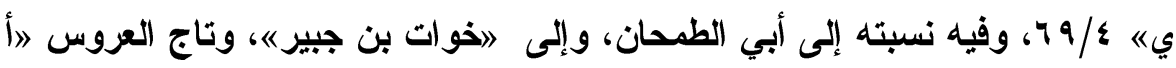

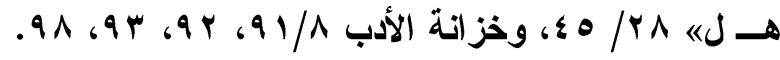

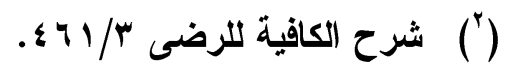

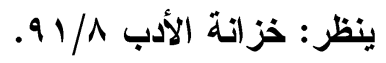

(") قلت ثبت ورود (أهلة) بالتاء، ويؤيده البيت الثاهد، لكن بقي أمر لا يخلو من فائدة، 


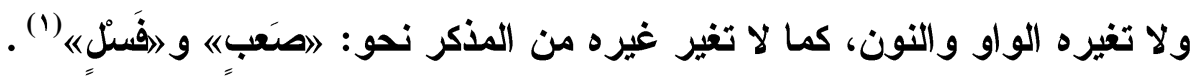

اللغة:

وأهلة ود: أي مستحقون له، تبريت ودهـــ: تعرضــت لــه(؟)،وأبليــتهم: أوصــلتهم

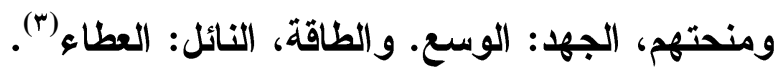

والمعنى: رب من هو أهل للود قد تعرضت له وبذلت له في ذلك طاقتي من نائلي (؛).

وهو أن 》أهلةه قد جمع على صورتين بناءً على نوعه: فهو اسم دخله معنى الصفة،

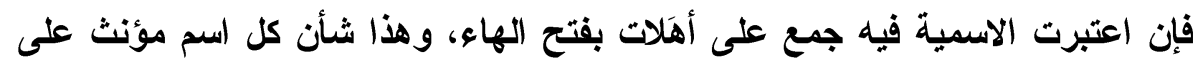

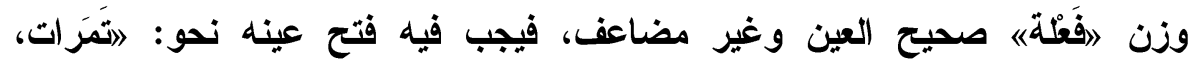

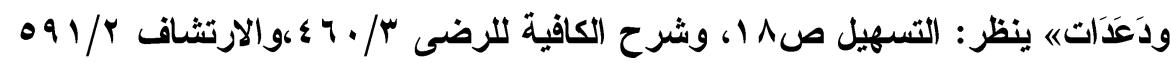
ومن مجيئ جمع »أهلةها اسمًا قول المخبل السعدي:

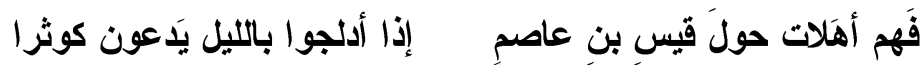

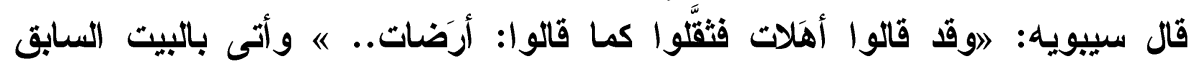

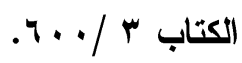
وقال الفراء بعد أن أورد بيت المخبل: 》 فجمع الأهلة: 》أهَلاته مثل: "حسَّرة

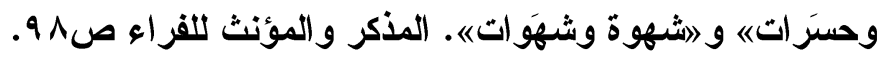

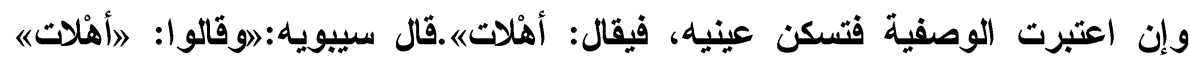

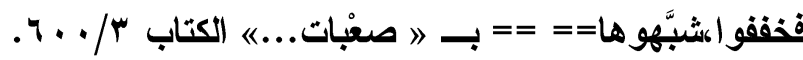
وقال ابن يعيش \... أثببه فَعْلة الصفات فجمعوه بالألف والتاء وأسكنوا الثاني فقالوا:

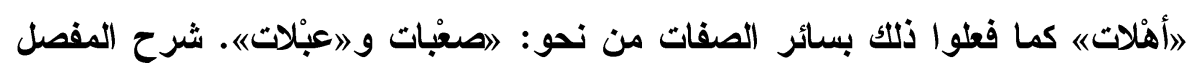

$$
\begin{aligned}
& \text {. } \\
& \text { (الكتاب س/ } 999 . \\
& \text { إصلاح المنطق صع \&ه } 1 \text { أ. } \\
& \text { خزانة الأدب ^/ع ع } 9 .
\end{aligned}
$$

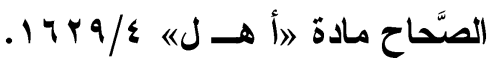


نفي »الاه الماضي لفظًا ومعنى دون تكرارها

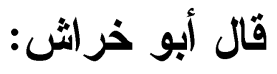

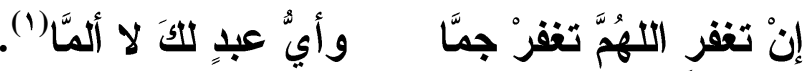

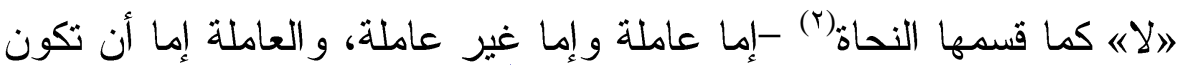

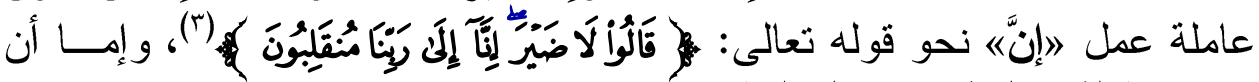
تكون عاملة عمل ليس كقول الثاعر :

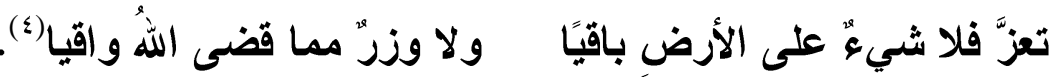

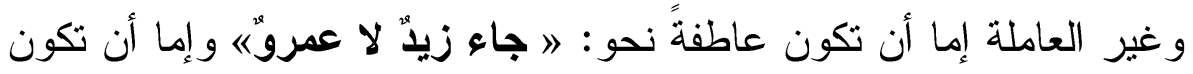
البيت من الرجز ،واختلف فى نسبته ، فقيل لأمية بن أبى الصلت ، وهو الكثير ، ونسب

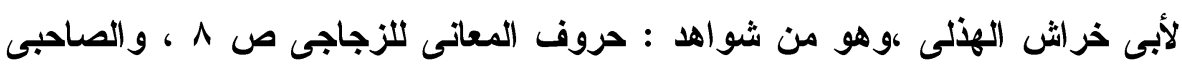

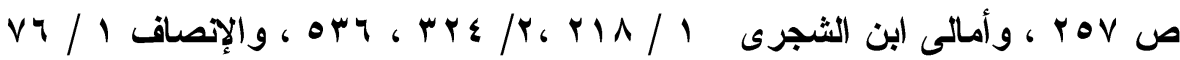

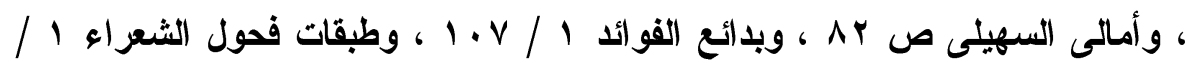

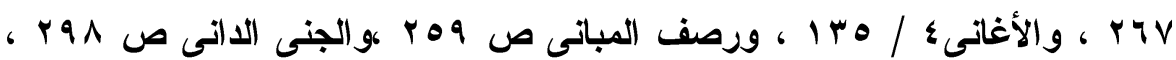

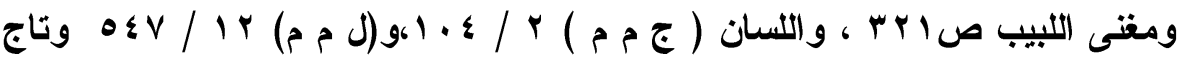

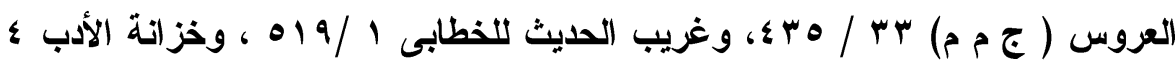

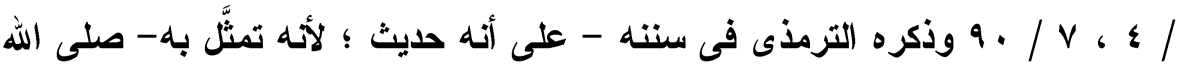

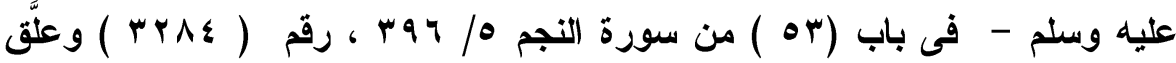

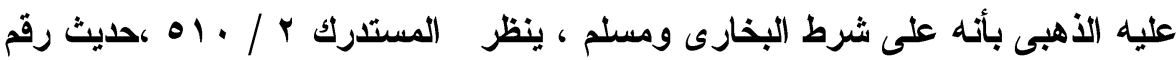
(rvo.)

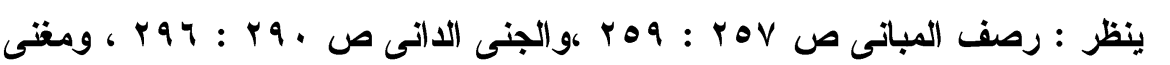

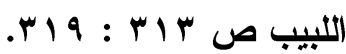

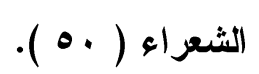

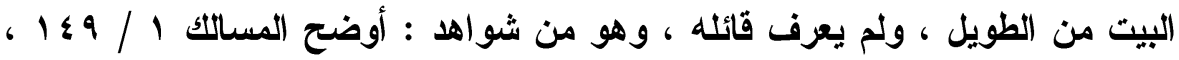

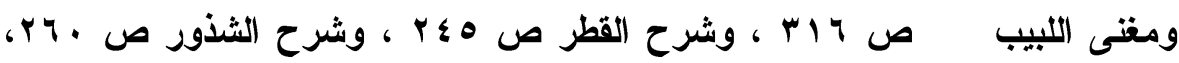

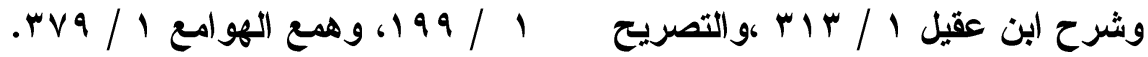




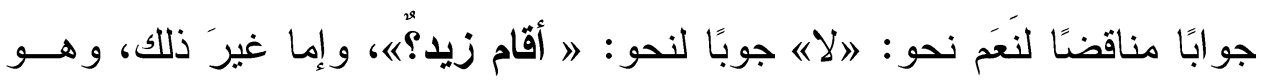
موضع حديثنا.

و "الا《 هذه يجب تكرارها في الصور الآتية:(1)

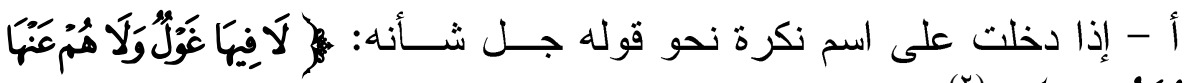

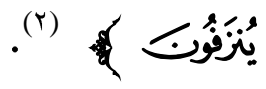
وشذ عدم تكر ار "لا" إذا دخلت على اسم نكرة نحو قول الثشاعر :

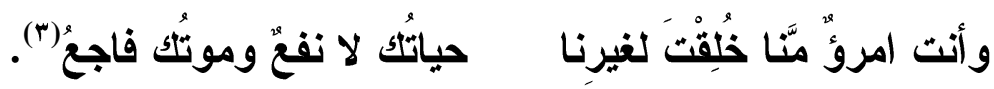

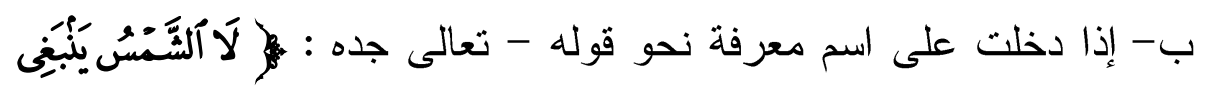

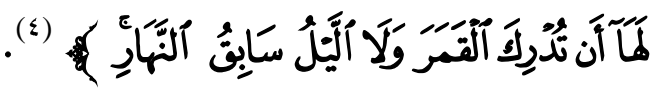

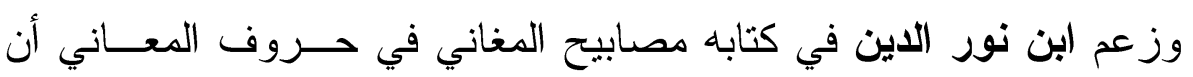

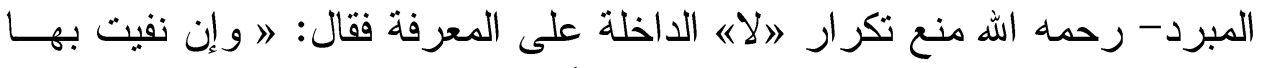

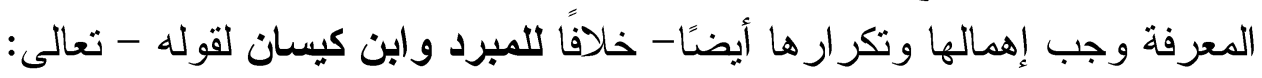

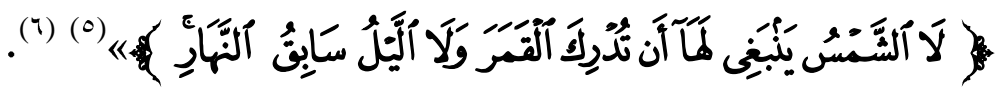
و الحق أن المبرد- رحمه الله- جعل التكرار في هذه الحالة غالبا، ولم يمنعه فقال:

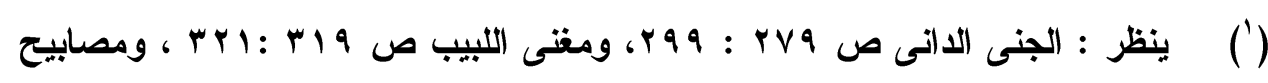

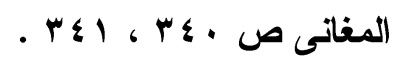

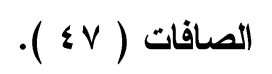

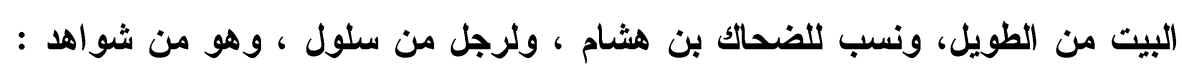

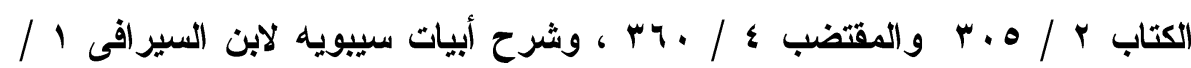

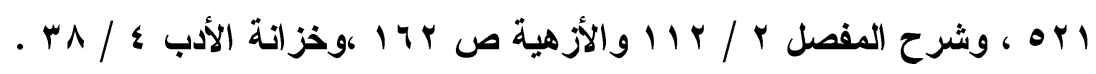




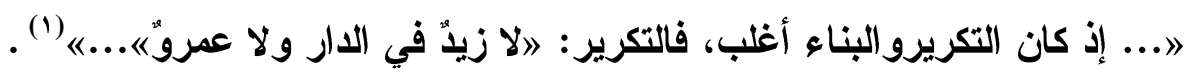

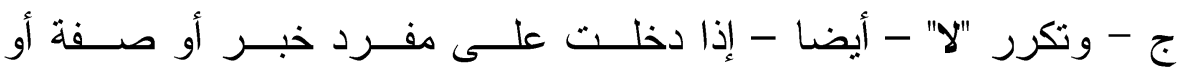

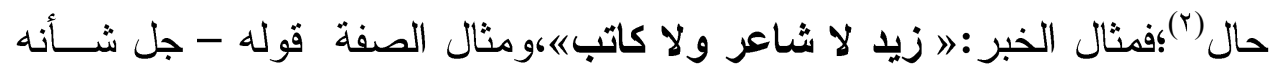

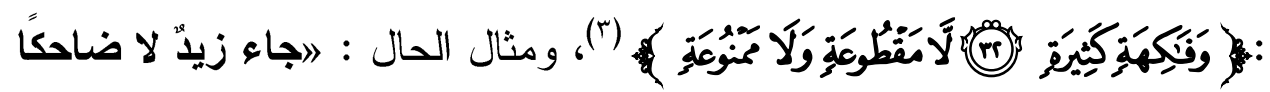
ولا باكيًاء. د- إذا دخلت على فعل ماضي لفظًا ومعنى، ودخولها عليــهـ قليـلـ(8) ووصــفه

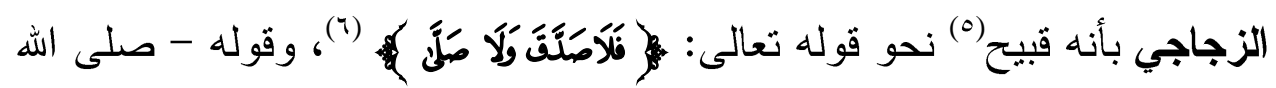

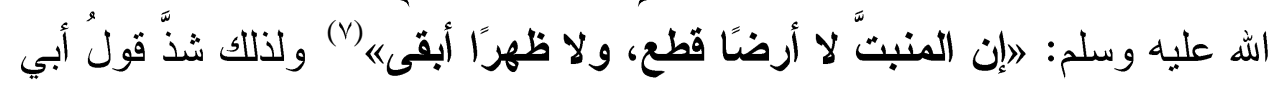

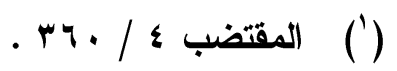

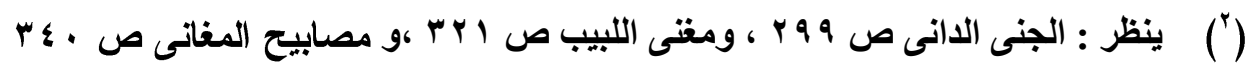

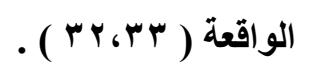

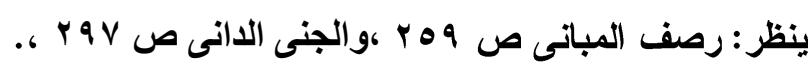

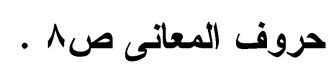

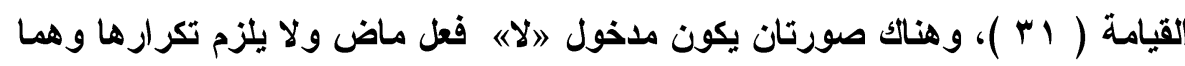

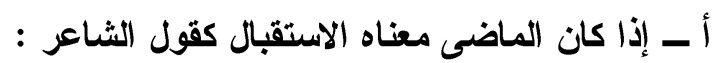

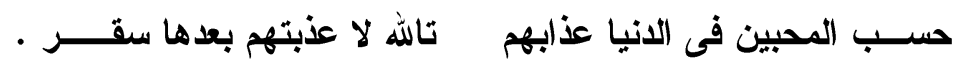

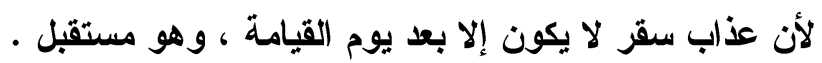
ب ـ إذا كان الفعل الماضى مقصودًا به الداعاء، والداعاء مستقبل في المغنى - أيضا - كقول عبيد الله ابن قيس الرقيات:

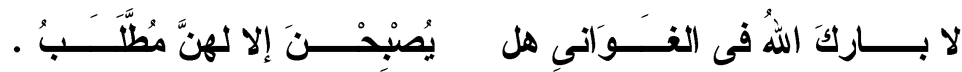

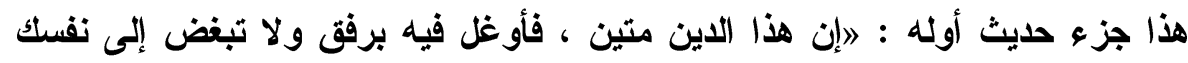

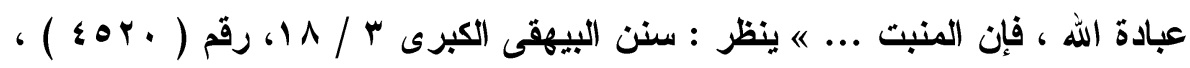




$$
\text { أبي خر اش السابق : }
$$

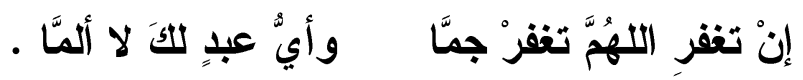

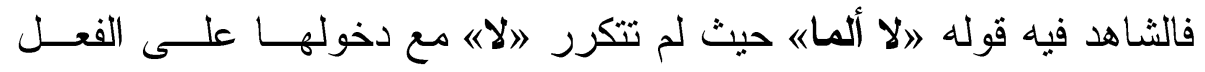

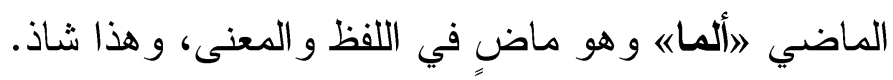

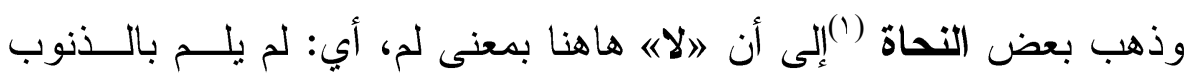
ودخول لم كثير على الفعل الماضي، وعليه فلا شذوذ.

\section{اللغــــــة}

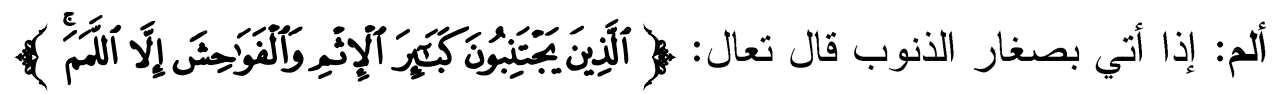

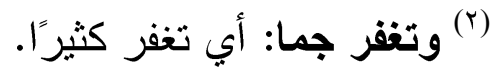

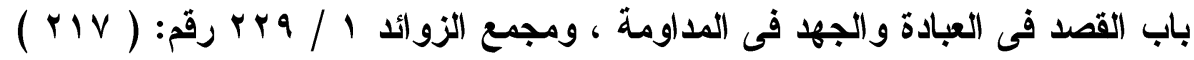

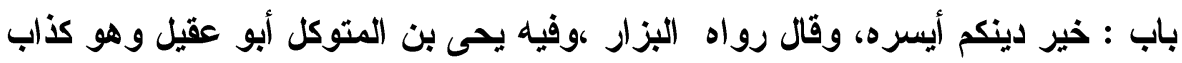

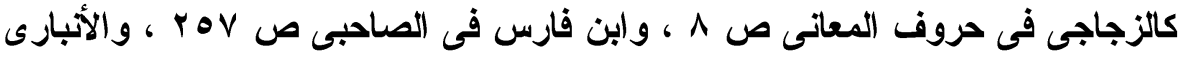

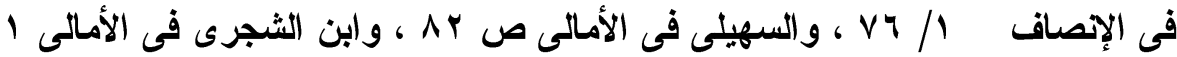




\section{نقل ضم عين الفعل المقصود به المدح إلى فائه}

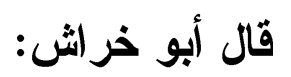

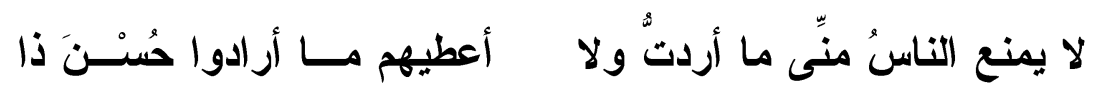

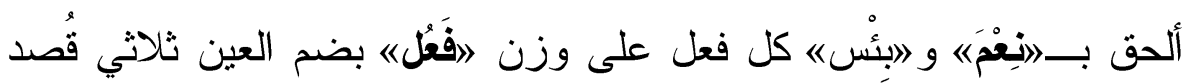

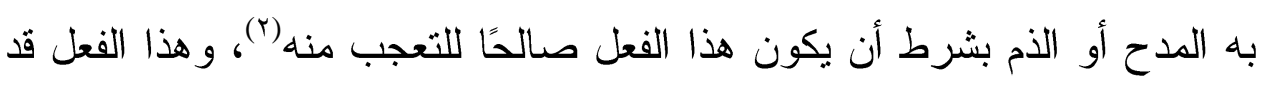

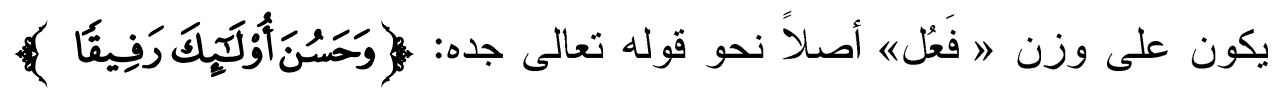

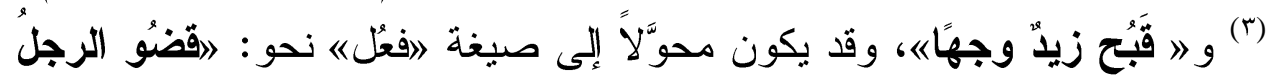

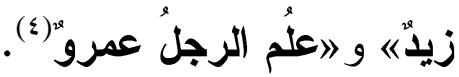

وفاعل هذا الفعل يخالف فاعل 》إنعِمه و "بئْس" فهو: " يكون معرفة ونكرة

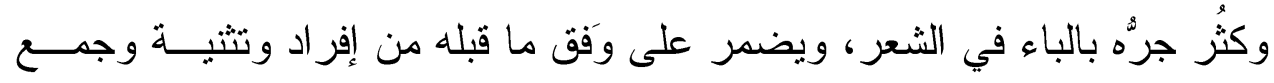

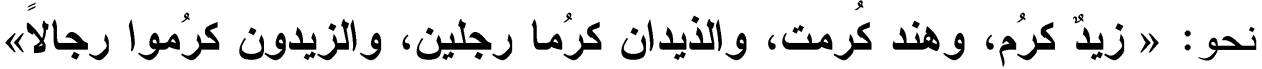

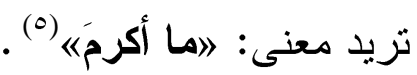

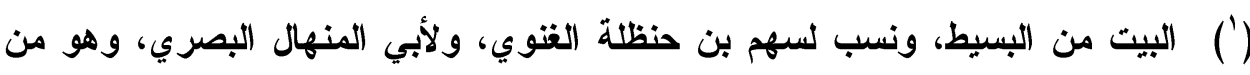

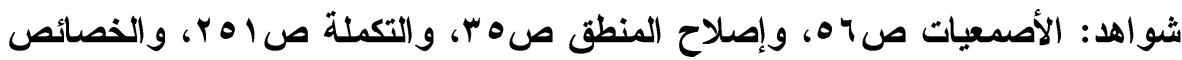

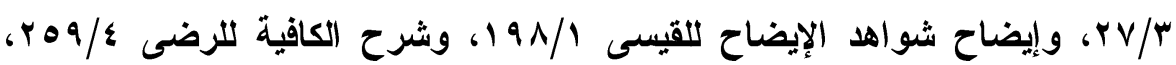

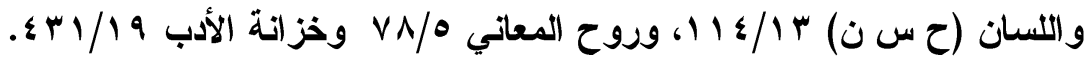

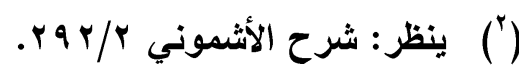

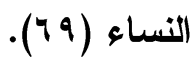

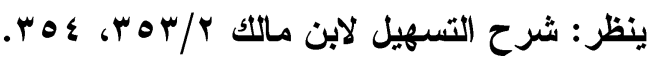


و "افَعُله هذا يجوز في حركة عينه أن تتقل إلى فائه أو تحذف ويبقى أولـــــ

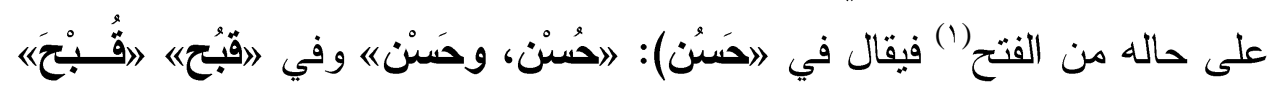

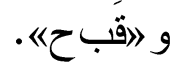

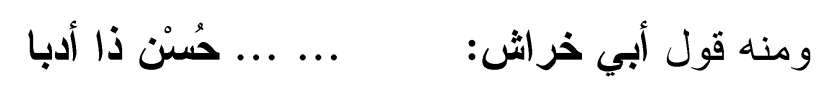

و الثاهد فيه قوله: "حُسنْ ذا أدباه حيث استعمل حسن للمدح و التعجب، وهو

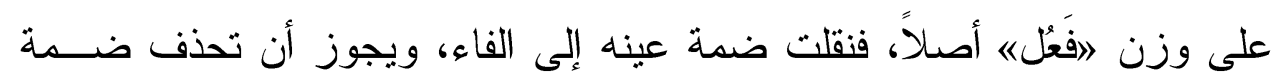

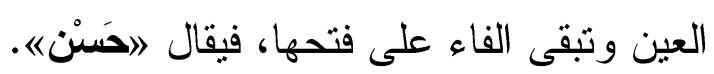

\section{اللغــة:}

الألفاظ و اضحة، لكن اختلف في معنى البيث على وجهين:(r)

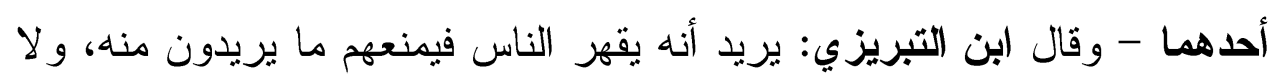

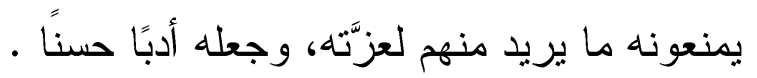

والآخر ذكره أبو العلاء وهو : كأنه ينكر على نفسه أن يعطيه الناس و لا يعطيهم،

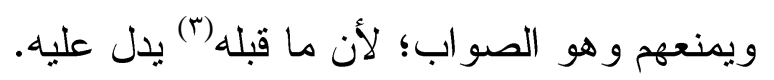

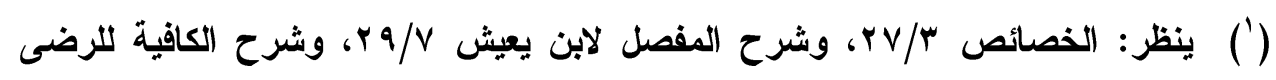

$$
\text { .rON/\& }
$$

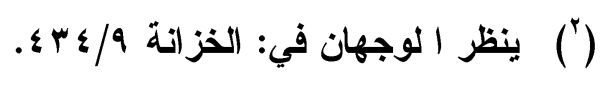

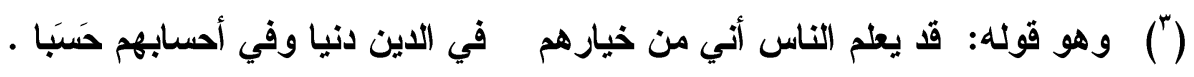

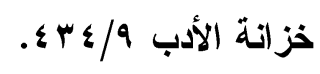


زيادة 》ماه أولا لضرورة الشعر

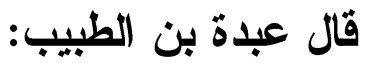

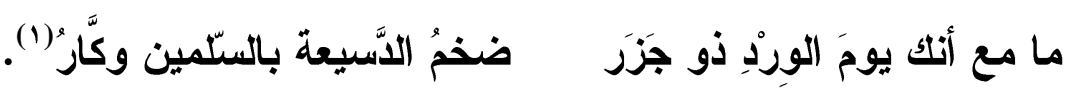

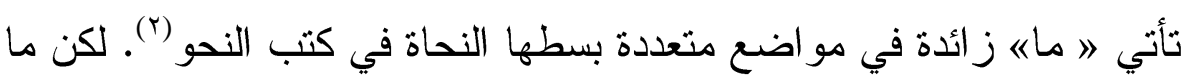

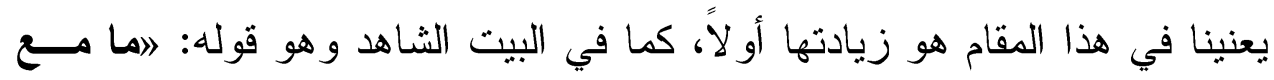

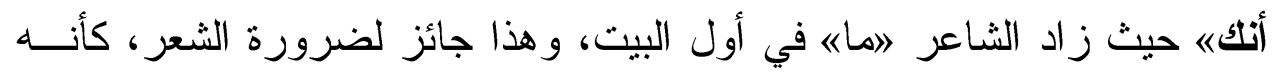

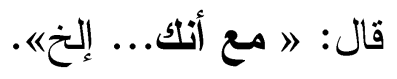

قال ابن عصفور: "او أقل من ذلكك زيادتها - أي: 》 ماه أول الكــلام نحـــ

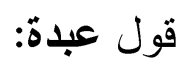

$$
\text { وهذا رأي جمهور النحاة) يوم الورد... البيته") }
$$

لكن الفارسي - رحمه الله- في البغداديات فرَّت بين ما إذا كانت 》اهماه زائدة

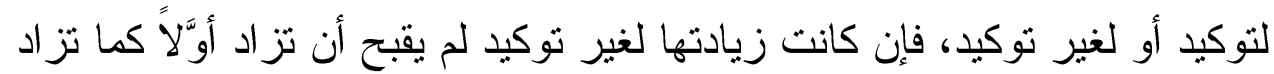

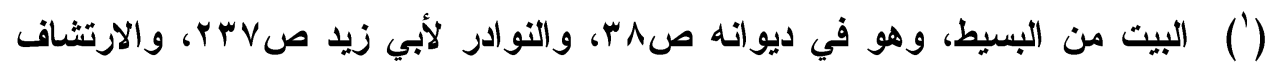

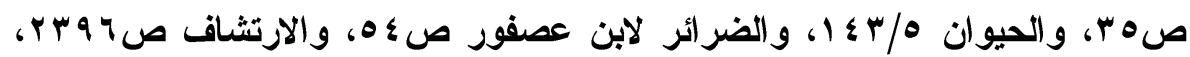

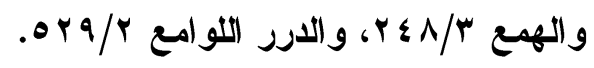

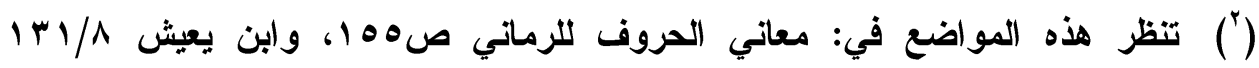

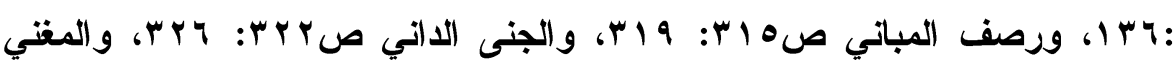


وسطًا و آخرًا، و إن كانت زيادتها لتوكيد قُبُح أن تقع أوَّلاً.

قال: "او إذا كان كذلك - أب: و إذا كان يجوز زيادة 》هاه في الكــلام لغيـر

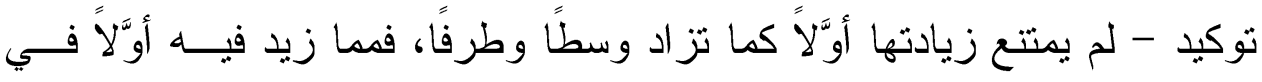

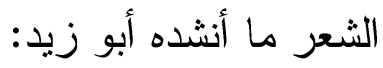

$$
\text { ما مع أنكك يوم الوردد... البيت. }
$$

... فذهب أبو زيد إلى أن 》ما《 زائدة.

ل... وينبغي لمن ذهب إلى أن زيادة هذه الحروف للتأكيد أن يستقبح الزيــادة

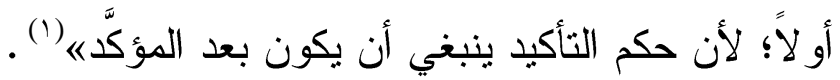

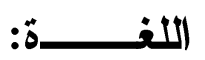

الجزرَ: القوة، والجزارة: القو ائم يعني بها يداه ورجلاه، والسِّمان، الدلوان،

$$
\text { والوكَّار: العدَّاء. }
$$

وقال أبو الحسن:؛ الجزر: كثرة اللحم والتعضيل هو حفظي (r). إثباع الحركة لضرورة الشعر

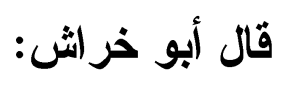

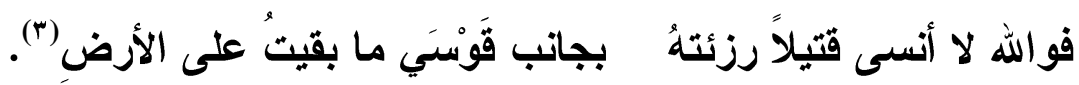

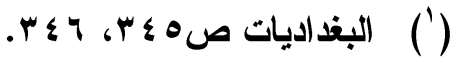

$$
\begin{aligned}
& \text { النو ادر لأبي زيد صVآباته }
\end{aligned}
$$

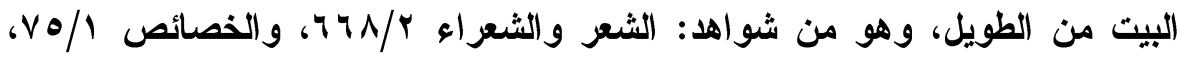

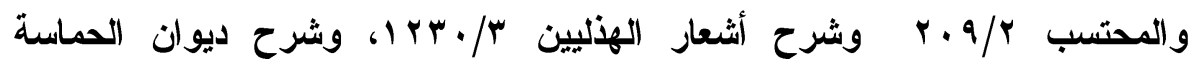

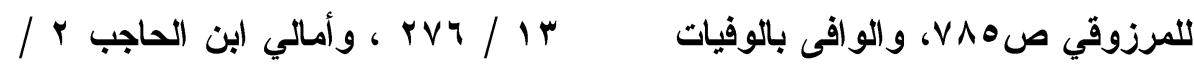


الشاهد فيه قوله: "رزئتهاه حيث أثبع ضمة الهاء، و هذا خاص بالشعر. قال ابن جنى: (العرب تقف على العَروض نحوًا من وقوفها على الضرب، أعني مخالفة ذلك لوقف الكلام المنثور غير الموزون.... وقوله:

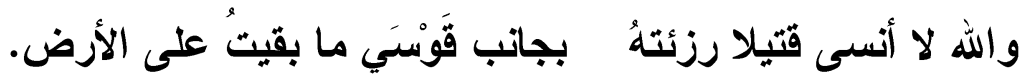

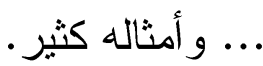

وكل ذلك الوقوف على عروضها مخالف للوقوف على ضــربه، ومخــالف

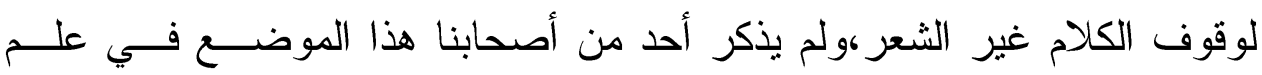

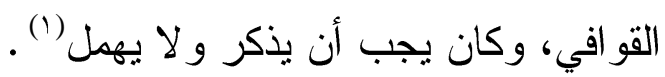
اللغة: المان قََْْسى: بلد بالسَّر اة(؟).

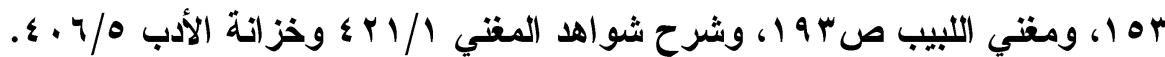

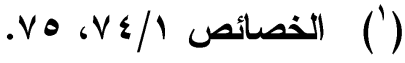

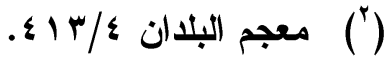


מ

\section{الفصـل الثــالث}

الشـواهــــــــــــــة 
دلالة صيغة 》مُفعله على المصدر

وقال أبو خر اش:

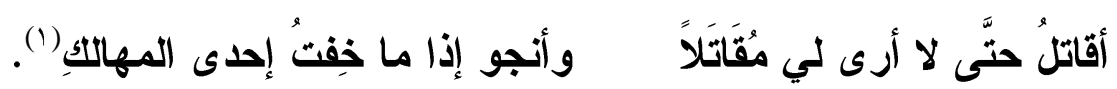
صيغة " مُفعل " من الصيغ التي تتعد استعمالاتها صرفيًا، و السياق وحده

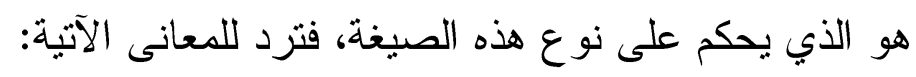

الأول: أن تدل على اسم الدفعول من غير الثلاثي، ومنه قوله - عز من

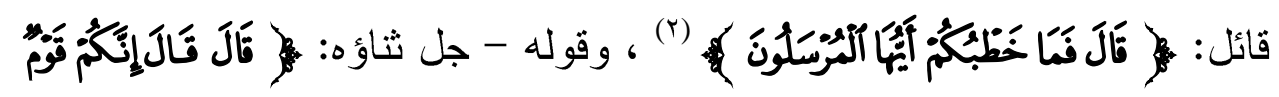

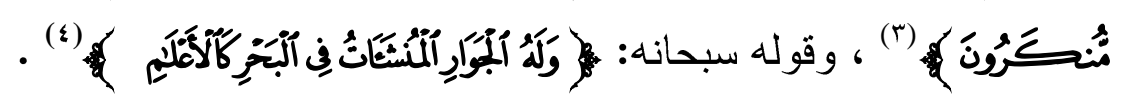
الثاني: الدلالة على زمان الفعل نحو: اوقت انطلاقك مُلتقى أخيكهـ.

(البيت من الطويل، وهو من شواهد، شرح أثعار الهذليين صاءع ا، وشرح عمدة

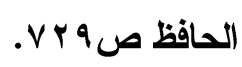

وهناك بيتان يتفقان مع البيت الثاهد في الصدر وهما: قول مالك بن أبي كب أبو كعب

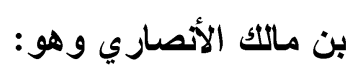
أقاتل حتى لا أرى لـــي مقاتلاً وأنجو إذا غم الجبان من الكرب. وقول زيد الخيل:

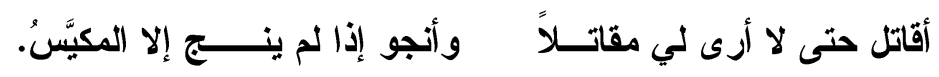

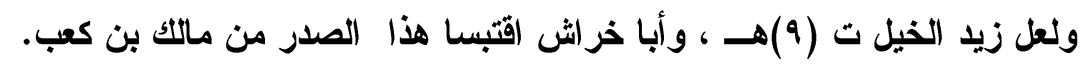

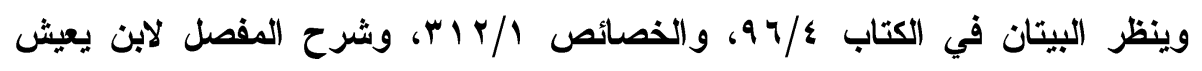




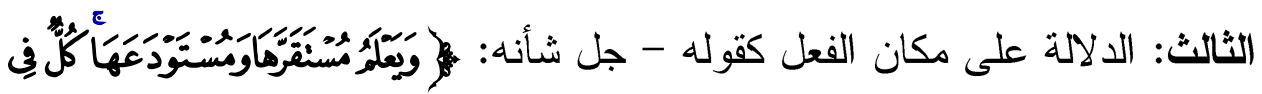

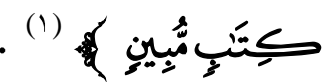

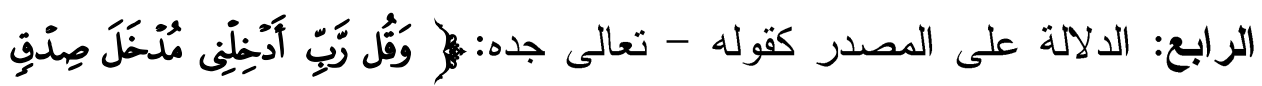

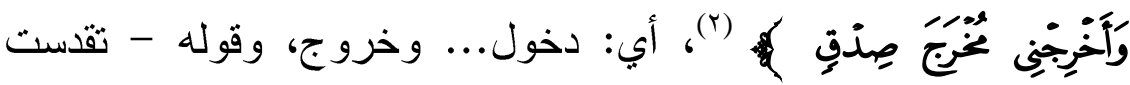

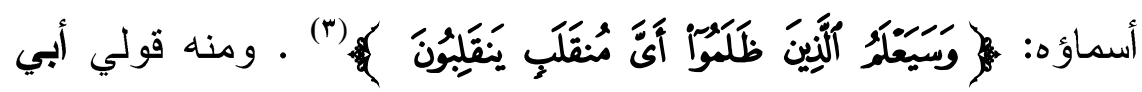
خراش:

$$
\text { أقاتل حتى لا أرى لي مقاتَلاً... البيت. }
$$

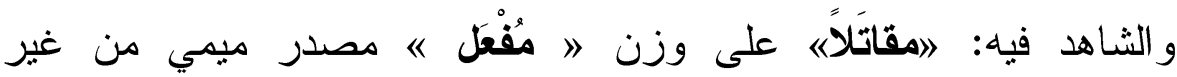

الثلاثي () ، أي: أقاتل حتى لا تنقى لي قدرة على القتال (o).

$$
\text { قال ابن جنى: " . وأما قوله: }
$$

فمدر، ويبعد أن يكون موضعًا، أي: حتى لا أرى لي موضعًا للقتال،

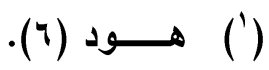

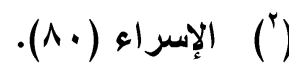

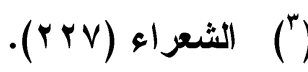

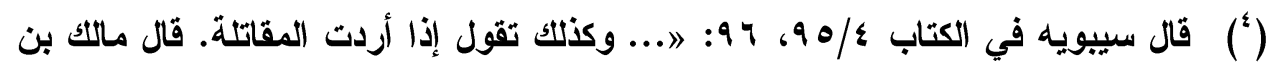

$$
\begin{aligned}
& \text { أبي كعب أبو كب بن مالك الأصصاري: } \\
& \text { أقاتل حتى لا أرى لي مقاتَـلاً و وأنجو إذا غُمَّ الجبان من الكرب. }
\end{aligned}
$$

$$
\text { وقال زيد الخيل: }
$$

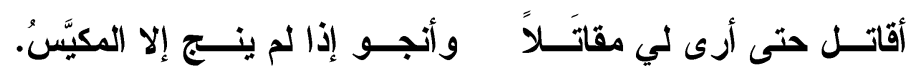

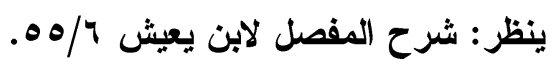




\section{المصدر هنا أقوى و أعلى" (1) .}

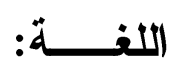

ألفاظ البيت واضحة لا تحتاج إلى بيان، و الثاعر -هنا- يفخر بنفسه ويصفها

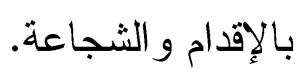

\section{جمع "جُرْح" على "أجراح) شاذ أو ضرورة}

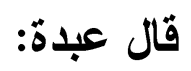

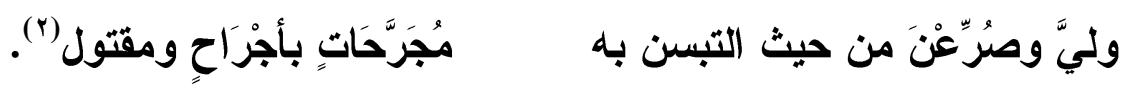

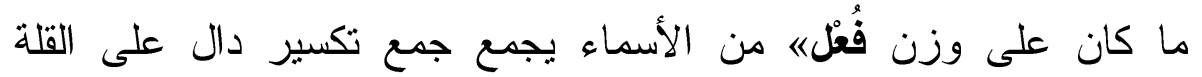

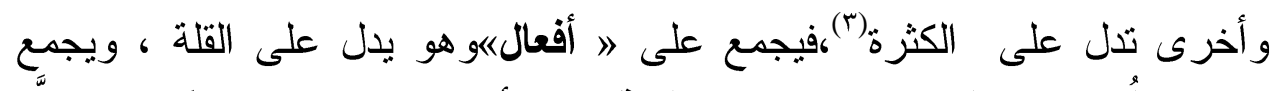

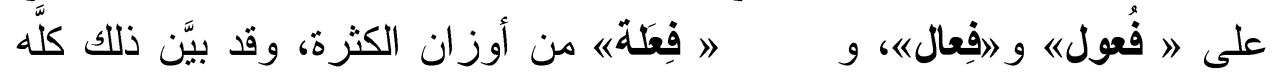

سبيويه.

يقول: " وأما ما كان على ثلاثة أحرف، وكان 》فُقْلاًٍ فإن يكسَّر من أبنية

البيت من البسيط، وهو من قصيدة طويلة تربو على الثئه الثمانين بيتا، ضمن أبيات

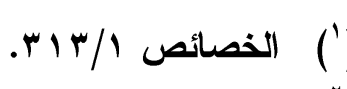

يصف فيها ثورًا اجتمت عليه الكلابَ، وقبله:

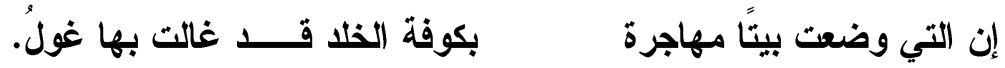

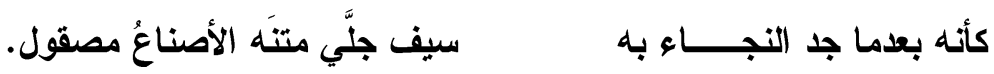

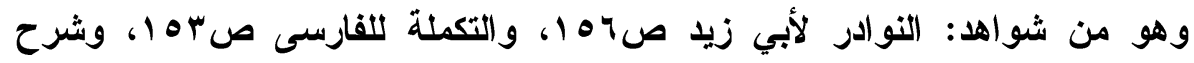

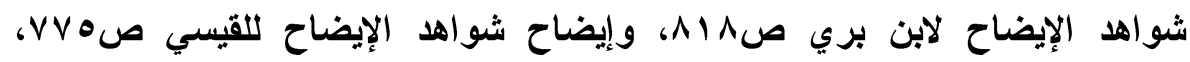

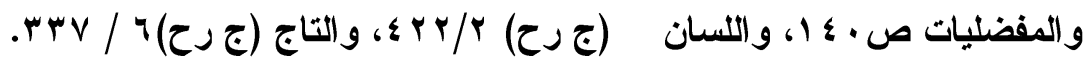

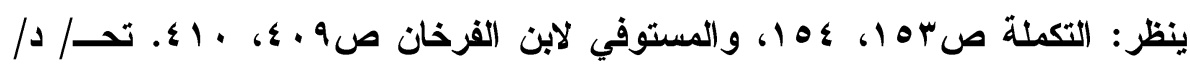

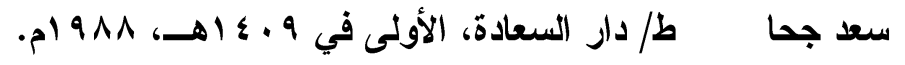




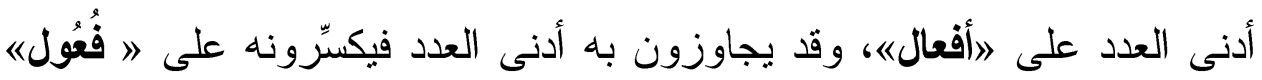

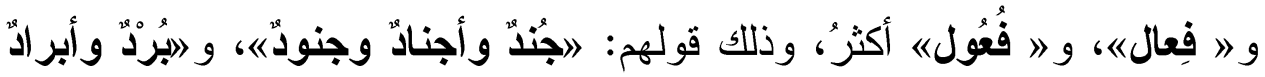

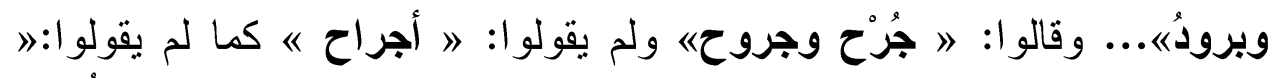

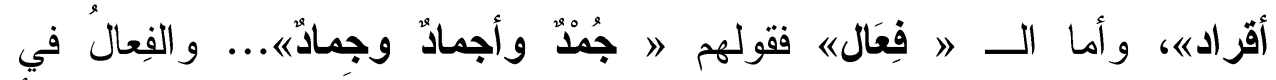

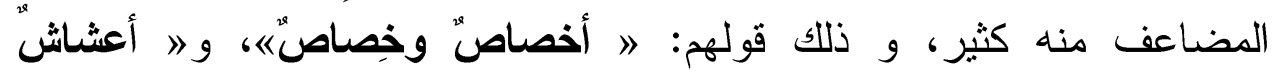

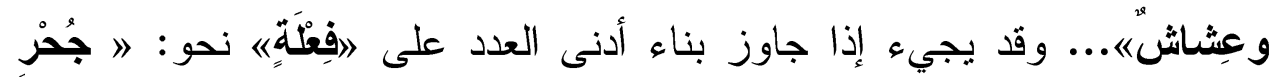

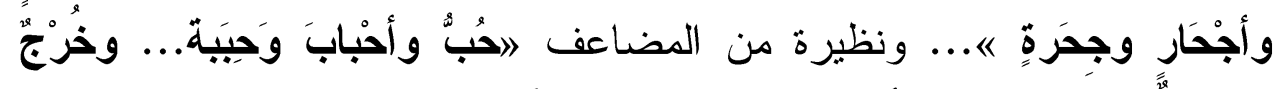

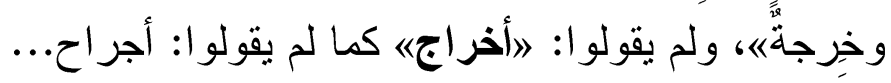

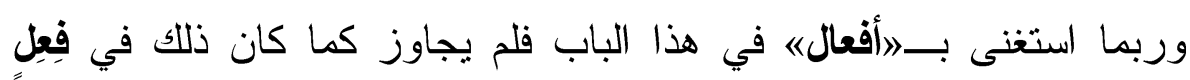

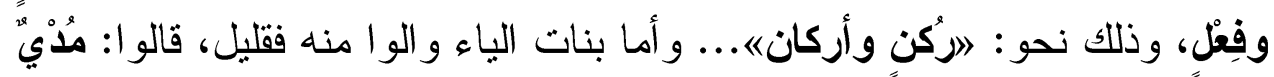

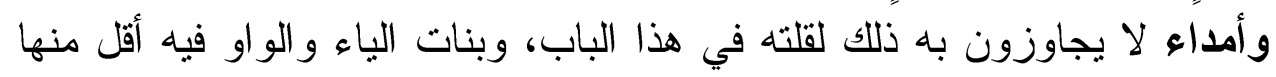
في جميع ما ذكرنا.

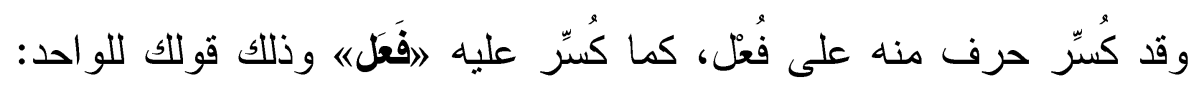

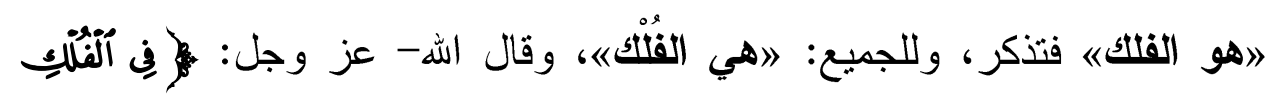

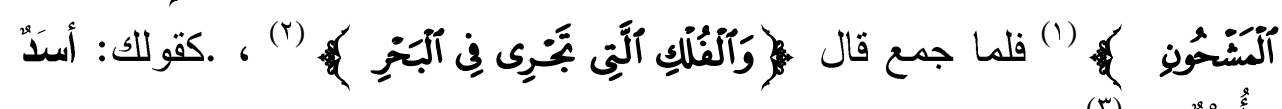
وأُسْدّ... (r)

من خلال ما سبق عن سيبويه - رحمه الله- نعلم أن جمع جُرح على فيلى

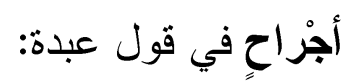
... محرجات بأجراح ومقتول.

من قبيل الثاذ الذي يحفظ ولا يقاس عليه، أو من قبيل الضرورة التي تسوّة

$$
\begin{aligned}
& \text { (') (119) (119). }
\end{aligned}
$$

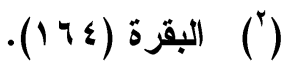

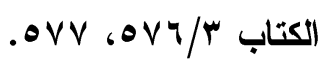




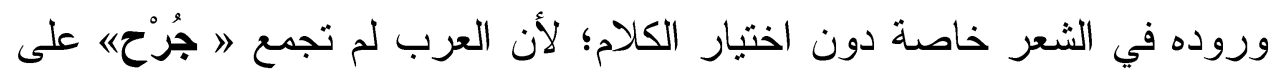

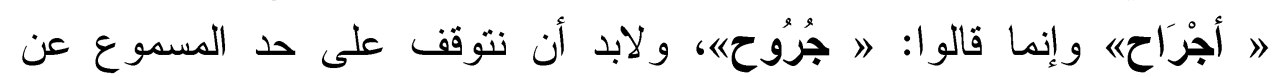

قال الفارسى: "... ويجوز على قول سيبويه أن 》أجراح" جاء في الثعر

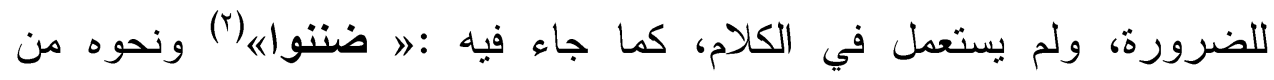

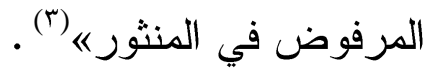

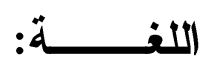

وليَّ: أي الثور، وصرُِّعن: أي: الكلاب، التبسن به:اختلطن به.

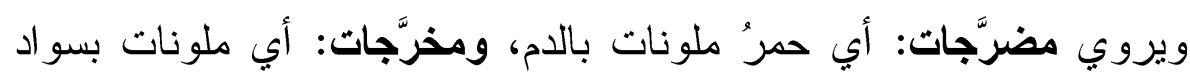

" لم يعرض كثير من النحاة والصرفيين لجمع التكسير في مؤلفاتهم، وعثلَّ بعضهم ذلك

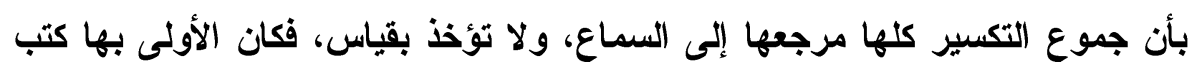

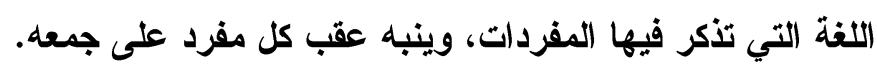

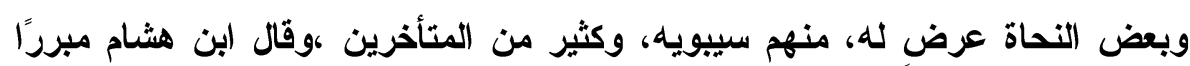

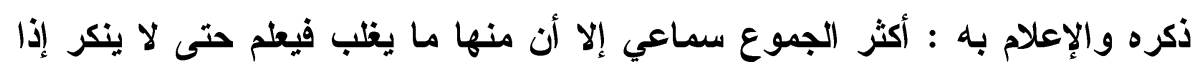

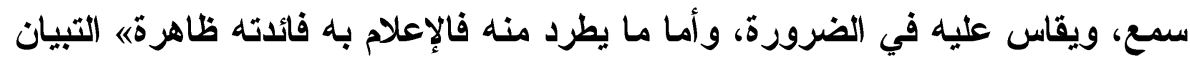

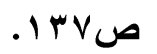
هذا جزء بيت من البسيطوتمامه:

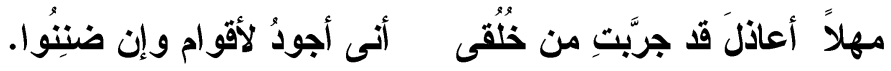

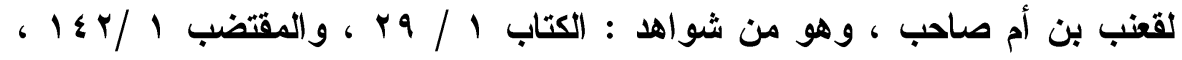

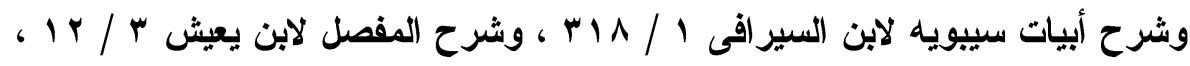

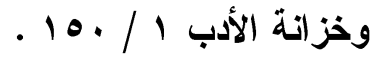
و الثاهد فيه " ضننو ا " حيث فلك إدغام النون ضرورة.

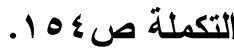


وبياض و غير ذلك من الألوان، ومجرَّحات: أي منها مجرحات('). و المعنى: 》 يصف ثور ا وكلابًا. يقول: وليَّ الثور، وصرعت الكلاب، فمنهن

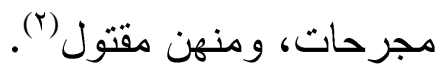

\section{جمع مِرْجل على مر اجيل للضرورة}

قال عبدة بن الطبيب:

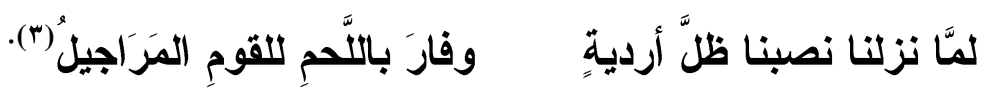

ما كان على أربعة أحرف أصلية نحو : » جعفر، وبرثن، وزبرج، وقمطره،

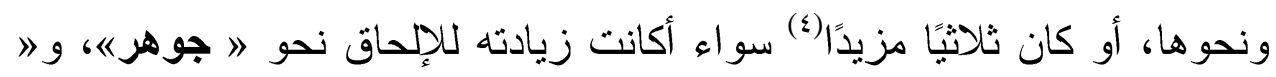

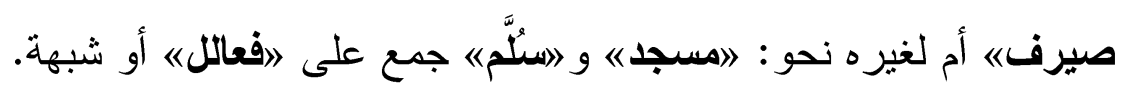
فيقال: "(جعافر، براثن، زبارج، قماطر، جواهر، وصيارف، ومساجد،

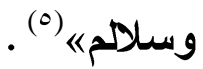

هذا إذا لم يكن رابعه حرف لين، فإن كان رابعه حرف لين جمع على "

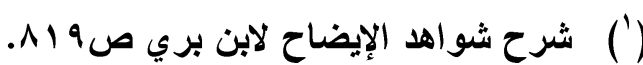

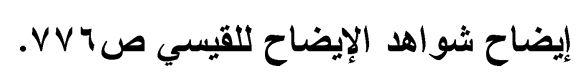

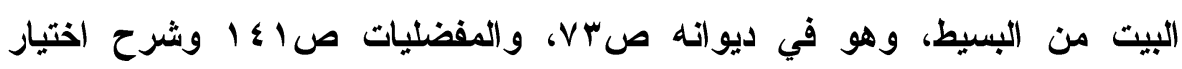

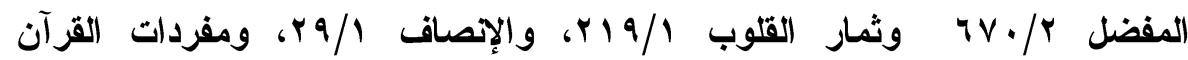

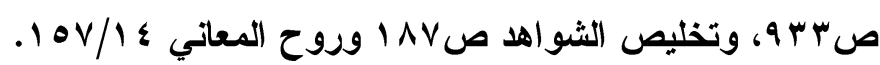

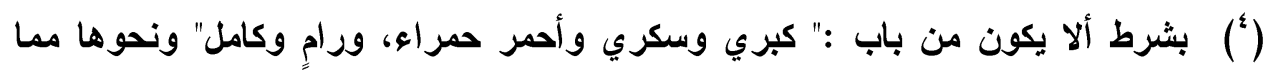

استقر تكسيره على غير هذا البناء.

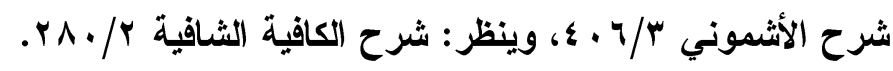

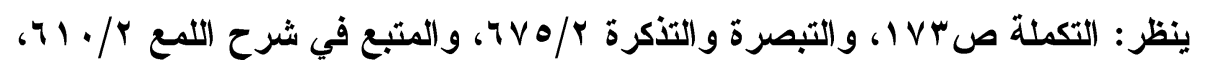

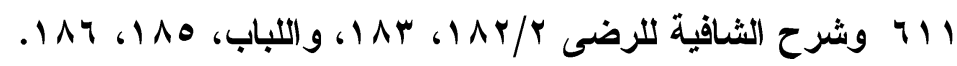




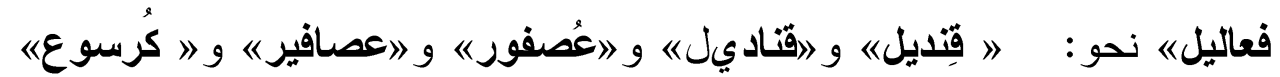
و " كر اسيع «" (1)

قال سيبويهه: لاو أما ما كان من بنات الأربعة لا زيادة فيه، فإنه يكسَّر على

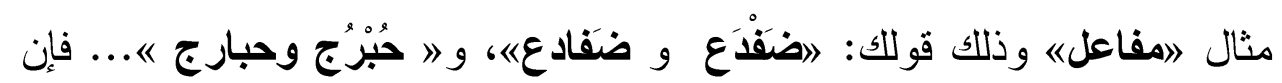

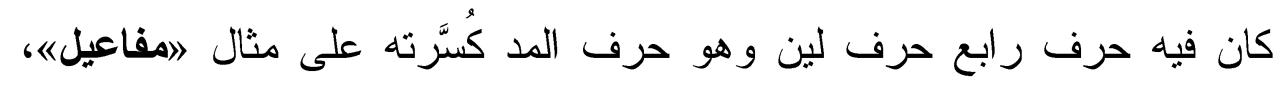

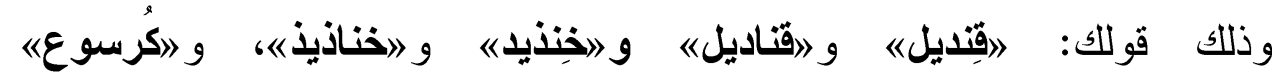

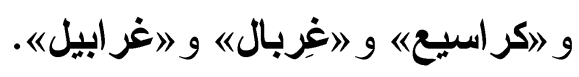
و اعلم أن كل شيء من نبات الثالثة فلحقته الزيادة فبني بناء بنات الأربعة

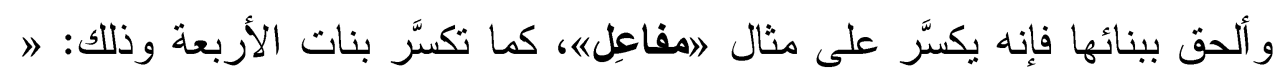

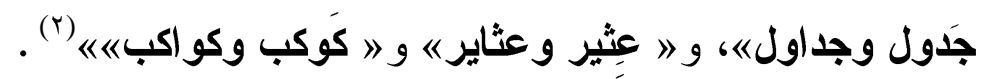
فإذا حذفت الياء من مثال 》مفاعيله، أو زيدت في مثال 》 مفاعله كأن هذا من قبيل الضرورة عند البصريين (r). ومن زيادة الياء في مثال » فعاللِ لأجل الضرورة قول عبدة:

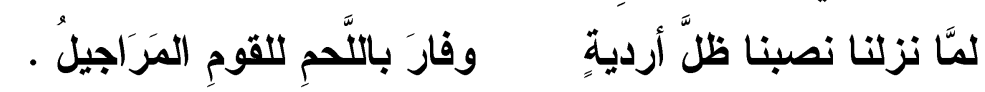
فالشاهد قوله : " المَرَاجيلُه جمع مِرْجل ، فزاد الياء فيه للضرورة؛ لأنه

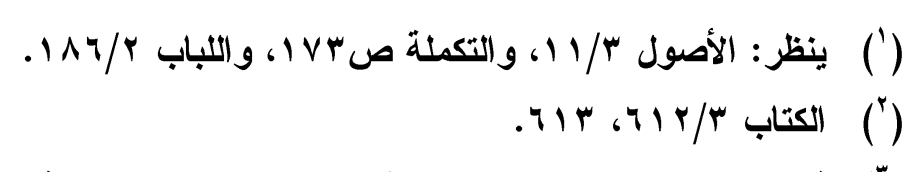

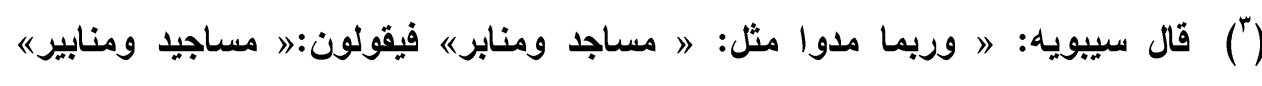

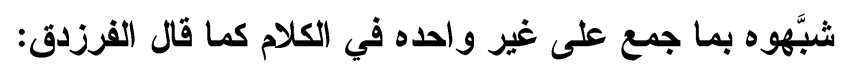

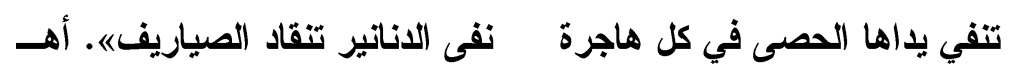

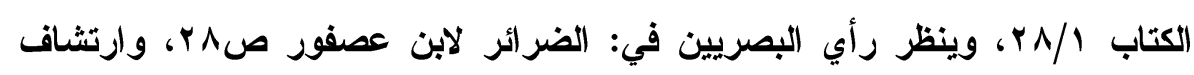

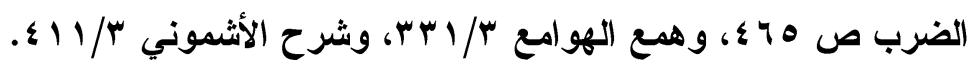


ليس رابعة حرف لين، فقياسه أن يجمع على مفاعل فيقال: » المر اجل «.

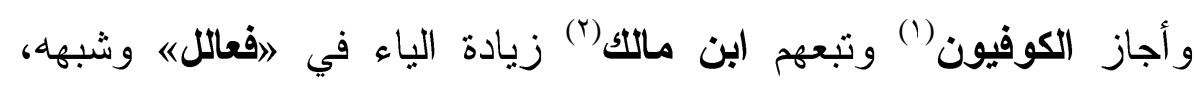
وحذفها من 》فعاليله وشبهه في الكلام. ونئ.

وعلى هذا المذهب يكون قول عبدة : 》 المراجيل " ليس من باب الضرورة، و إنما هو أمر سائغ جائز.

اللغــــة

فار: ارتفع بالغلى، المراجل: جمع مِرجّل كمينبرَ ،وهي القِدر (). ويروي: " وردناه بدلاً من: " نزلناه، ويروي: " أخبيةه بدلاً من: "

(') (حتج الكوفيون لمذهبه هذا بأنه قد ورد في القرآن الكريم حذف ياء "مفاعيل" وزيادة ياء على "مفاعل".

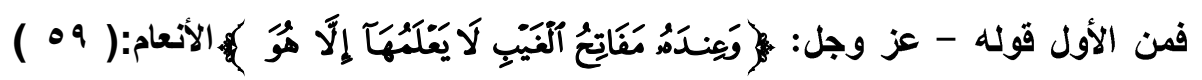
وهو جمع : "مفتاح " فحذف الياء.

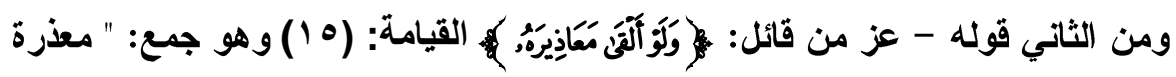
" فز اد الياء.

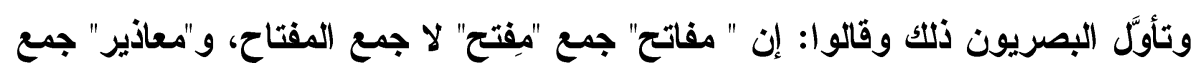

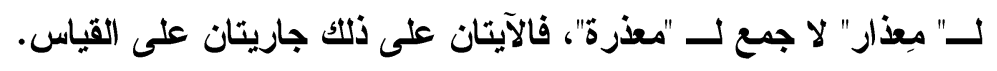

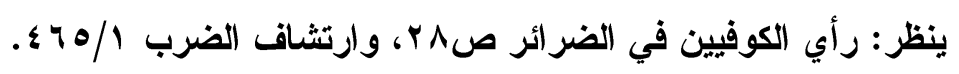

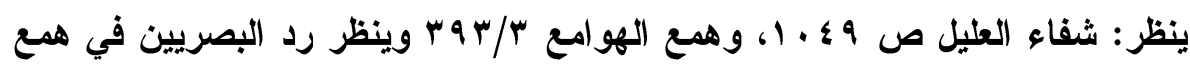

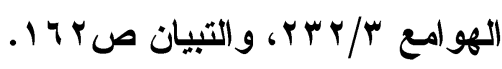

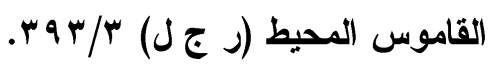




\section{حذف الياء والاجتزاء عنها بالكسرة من الفعل}

\section{》الا أدري《 لكثرة الاستعمال}

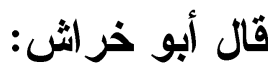

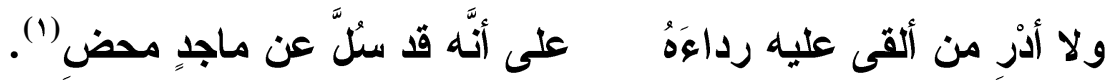

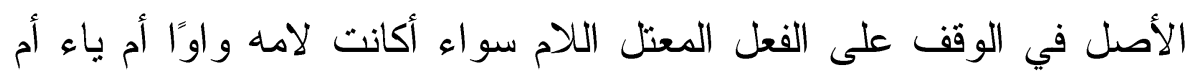

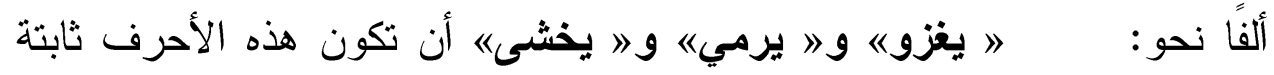

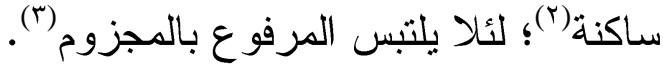

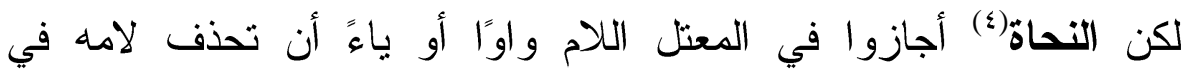

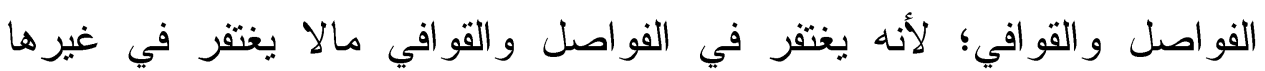

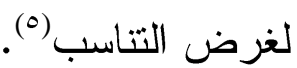

قال سيبويه: الوجميع ما لا يحذف في الكلام، وما يختار فيه أن لا يحذف فولف يحذف في الفو اصل و القو افي.

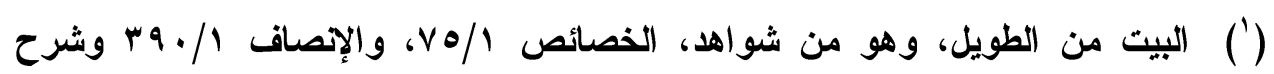

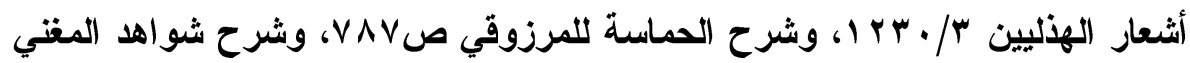

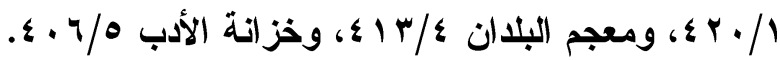

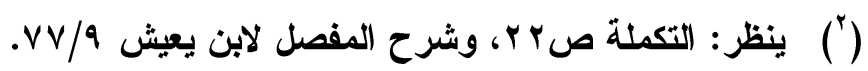

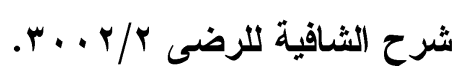

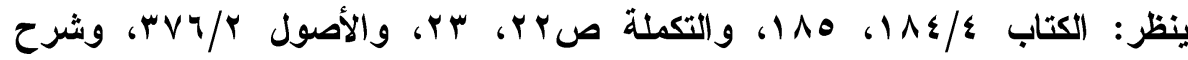

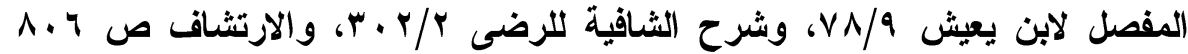




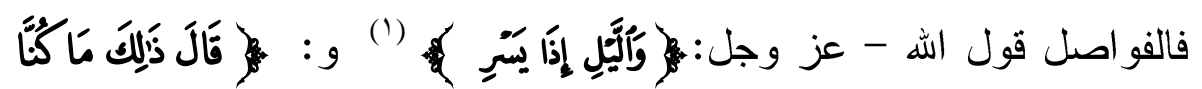

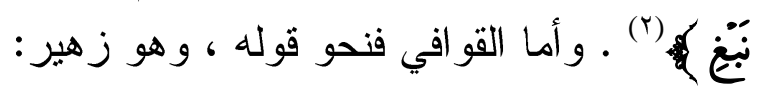

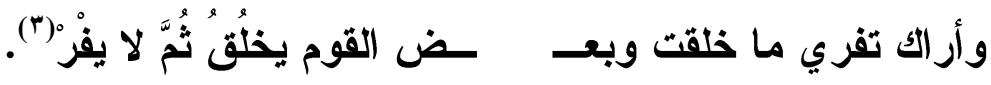

و إثبات الياءات و الو اوات أقيس الكلامين. و هذا جائز عربي كثيره(؛) .

أما إذا كان الفعل معتل الآخر بالألف فإنه لا يحذف منه شيء في الوقف

$$
\text { و الوصل. }
$$

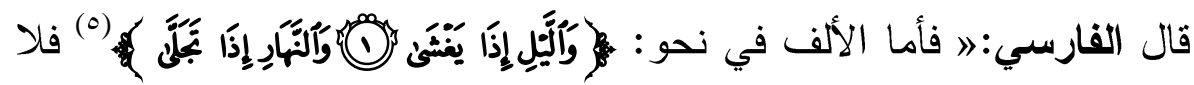

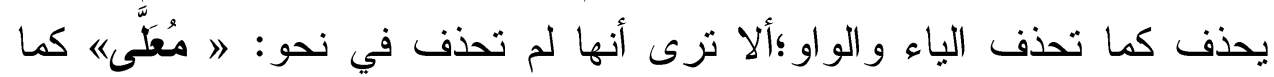

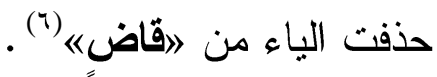

فإن ورد فعل مرفوع و لامه واو أو ياء وحذفت في غير ما سبق كان هذا

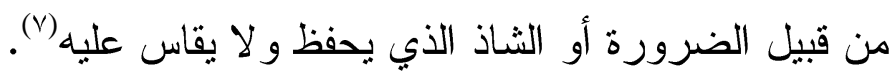
بيد أنه قد ورد عن العرب فعلان تجوزوا فيهما بحذف آخرهما في غير ما

$$
\begin{aligned}
& \text { (') ('الفجر (צ). } \\
& \text { الكهف (ع (4). }
\end{aligned}
$$

(") البيت من الكامل، وهو في ديوانه صم/r برواية: " ثم لا يفرى " وعليه فلا شاهد،

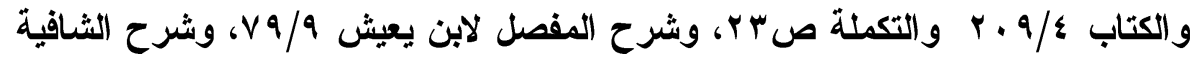




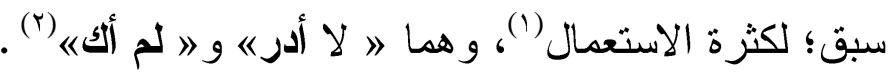

قال سيبويه: او أما الأفعال فلا يحذف منها شيء؛ لأنها لا تذهب في الوصل

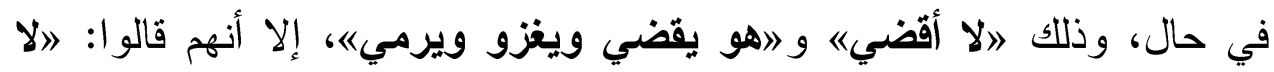

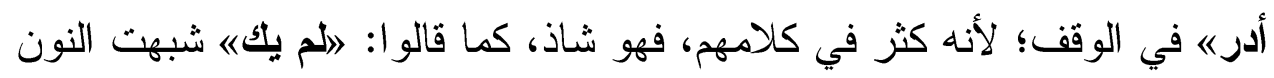

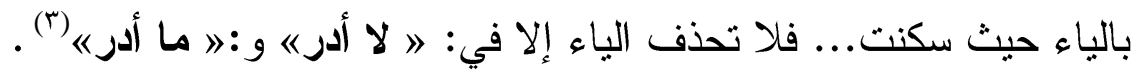
وقال ابن عصفور: " و إن كان - أي المعتل- مرفوعًا ثبتت الياء... إلا في

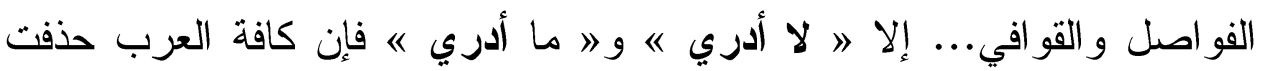

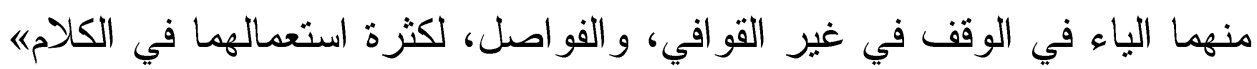

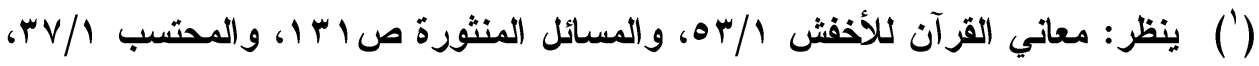

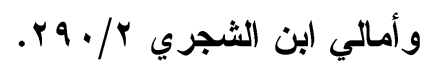

(") ورد في القرآن الكريم حذف لأواخر الأفعال المضارعة المعتلة الآخر واوًا وياءً في غير

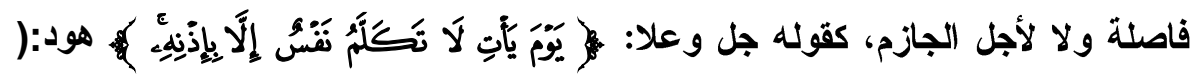

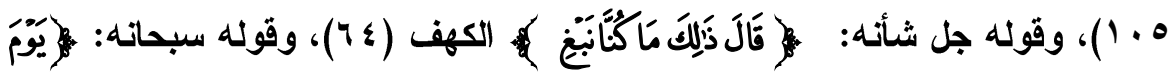

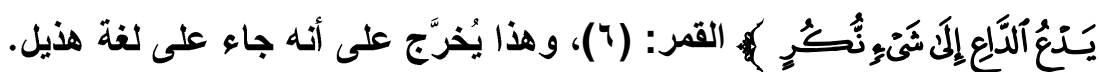

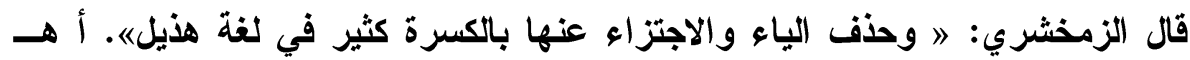

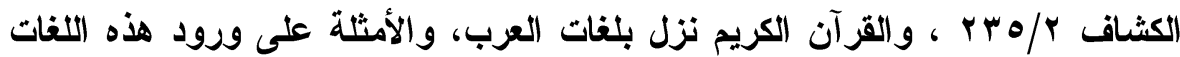
من القرآن الكريم كثيرة يضيف المقام عن ذكرها. وحمل الكلام على كونه لغة خير من حمله على الثذوذن.

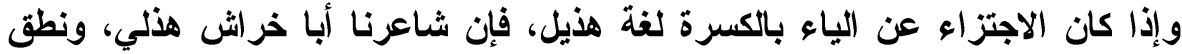

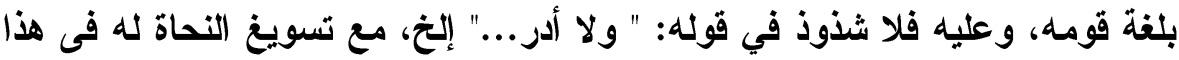

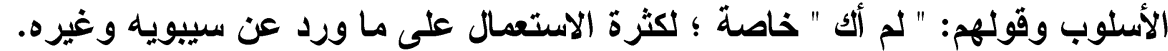

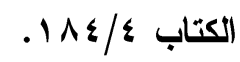


ولا أدر من ألقى عليه رداءة على أنه قد سُّلَّ عن ماجد محض.

فالثاهد فيه: 》 ولا أدر)؛ حيث حذف الياء من الفعل 》 أدريه في غير

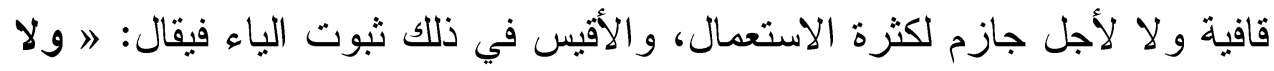

أدري《.

وروى: 》 ولم أدر "(r) فحذف الياء للجازم، و عليه فلا شاهد.

اللغــــة

ولا أدرى: لا أعلم، عليه، أي على عروة أخي الثاعر أبي خراش،

ومحض: خالص. 


\section{نقل حركة عين الأجوف إلى الفاء مع إسناده إلى الظاهر}

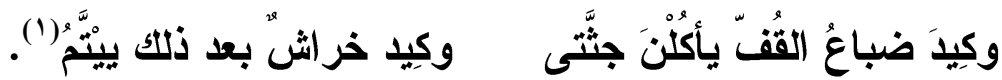

الفحل الثلاثي الأجوف إذا أريد إسناده إلى ضمير رفع متحرك فإنه يسكن آخره

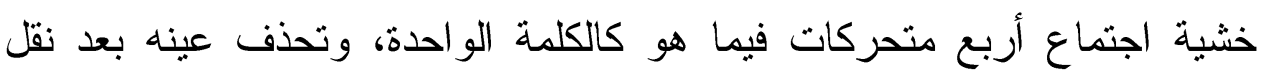
حركته (r) إلى الفاء لاكتفاء الساكنين.

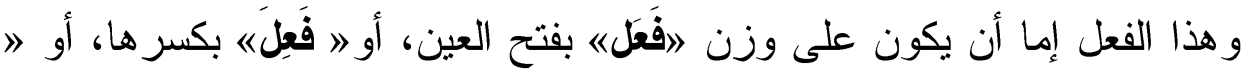
فَعُله بضمها.

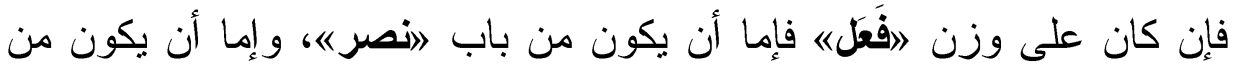

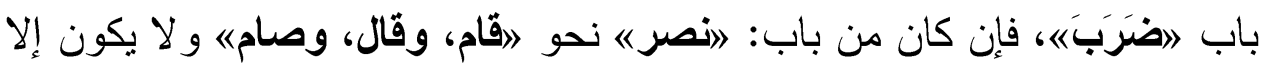

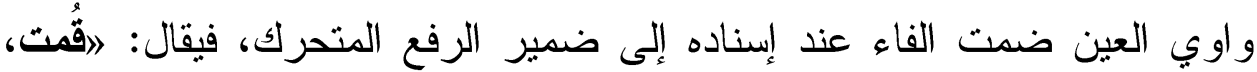

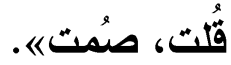

وإن كان من باب 》ضرب《 نحو: 》 باع، عاش، طابه ولا يكون إلا يأتي

البيت من الطويل، من قصيدة قالها لما نجا من بني لحيان حين هموا بقتله، وقبله:

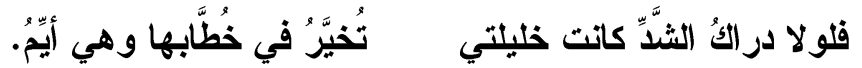

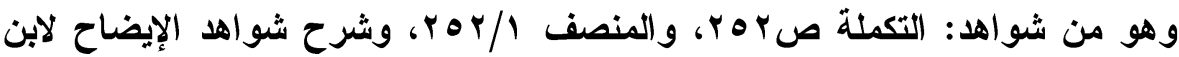

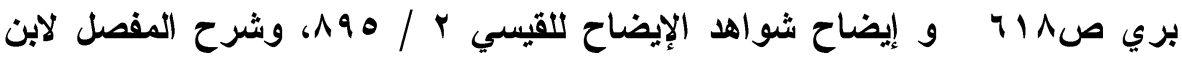

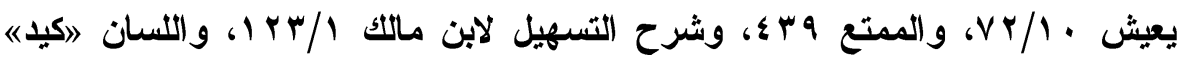

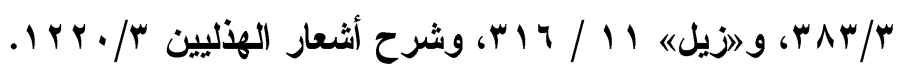

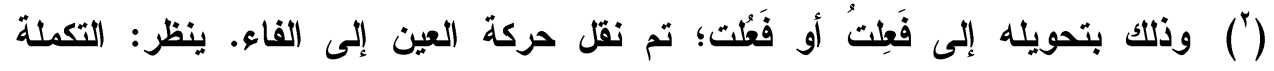


العين، كسرت فاؤه عند إسناده إلى ضمير الرفع المتحرك فيقال: 》 بعت،عت،

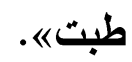

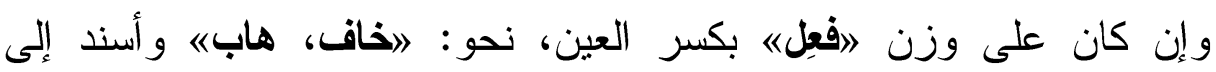

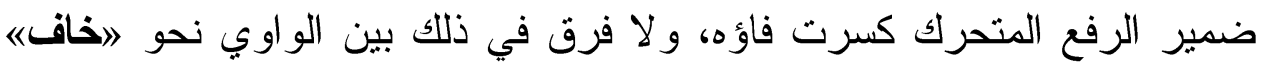

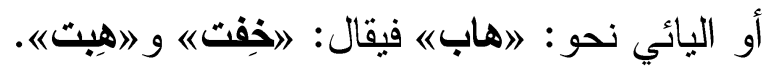

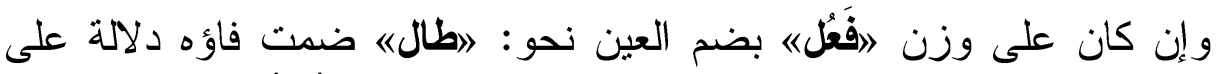

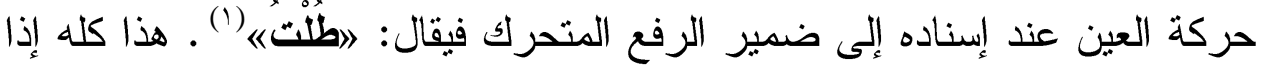

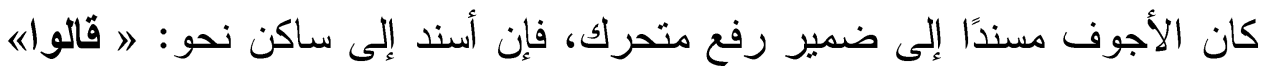

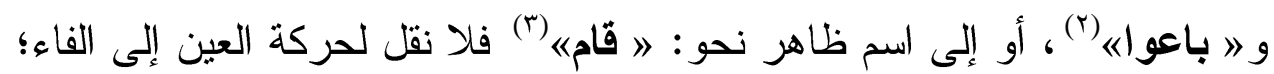

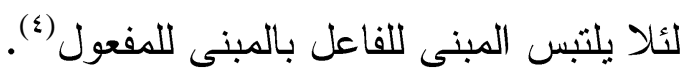

لكن حكي عن بعض العرب(0) أنهم ينقلون حركة العين إلى الفاء مع إسناد

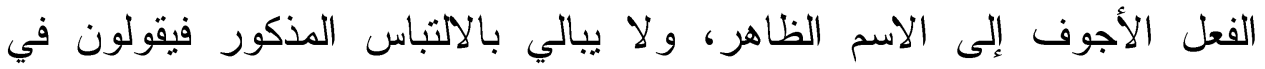

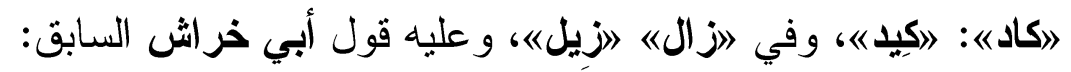

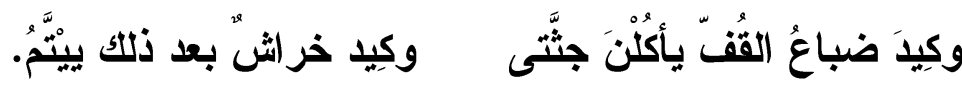

و الثاهد فيه: اوكيد ضباع... وكيد خراش《؛ حيث نقل حركة العين إلى الفاء

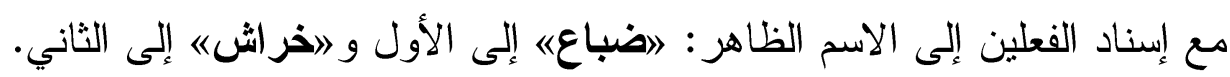

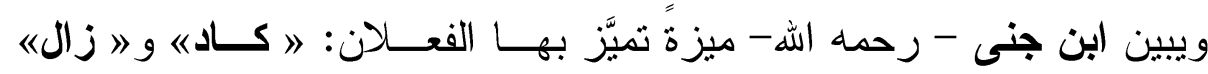

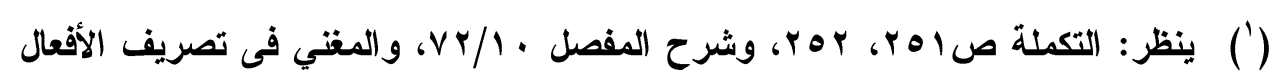

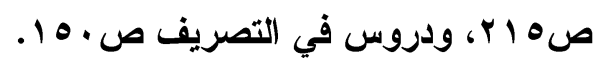

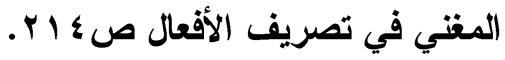

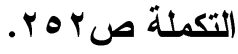

$$
\begin{aligned}
& \text { المنصف / rOr/l }
\end{aligned}
$$

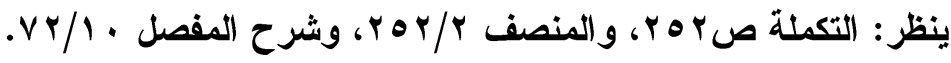




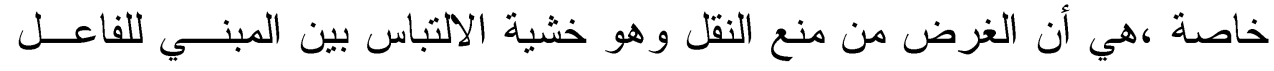

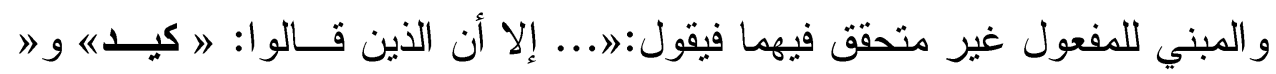

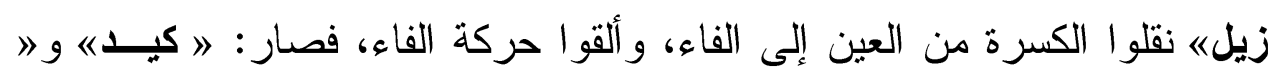

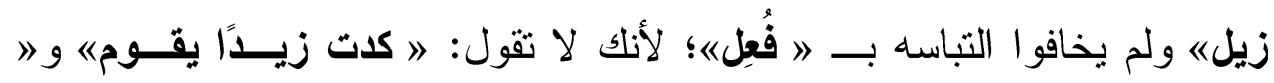

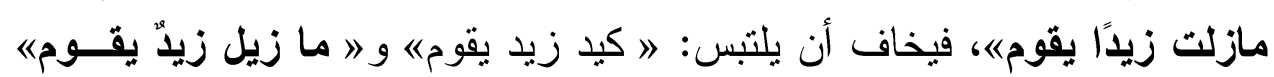

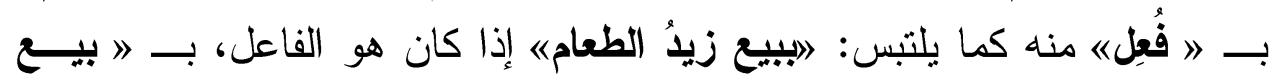

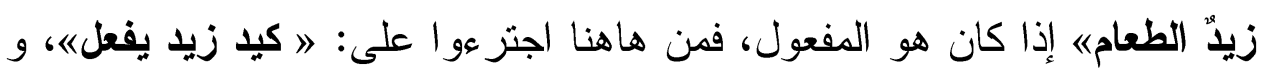

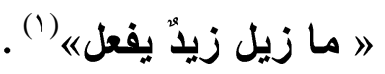
ويروي البيت:

فتقعد أو ترضى مكاني خليفة وكاد خراش" يوم ذلك ييتم (؟). و لا شاهد على هذه الرواية؛ لأن الفعل » كاده جرى على لغلى لغة سائر العرب. اللغنـــــة

القف: ما ارتفع من الأرض،والجثة: الثخص غير القائم، فإن كان قائمًا فيقال: قامته (r) ويروي: وكيات ضباع بدلاً من : وكيل ضباع(ء)، و: ايوم ذلكه بدلاً من: 》بعد ذلكى (0)

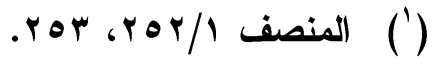

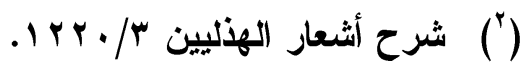

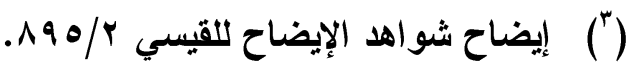

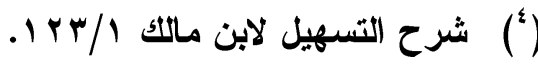

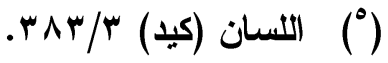




\section{$\ddot{a}$} خاتم

بعد هذه الرحلة مع شواهد الصعاليك المخضرمين لابد من ذكر أهم النتــائج التى توصل إليها البحث وهى هو على مالى ما يلى :

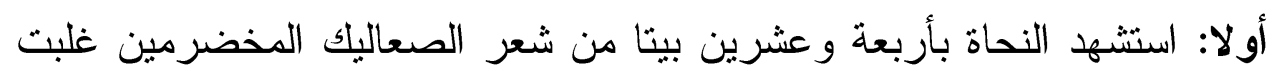

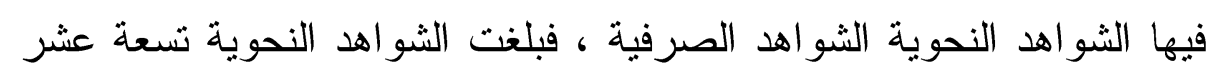

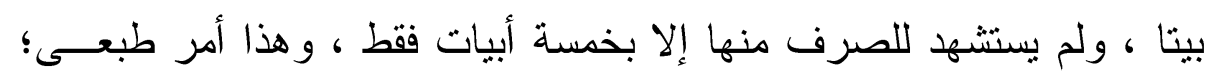
لكثرة القو اعد النحوية .

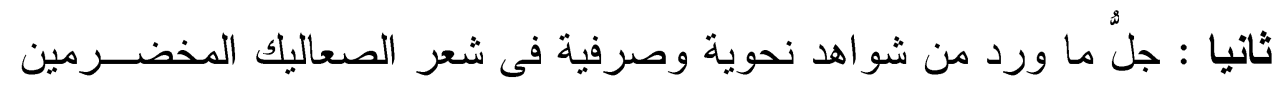

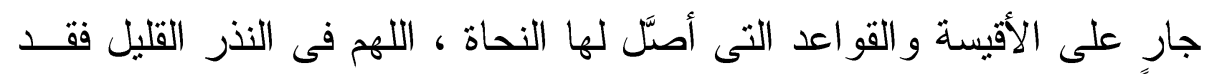

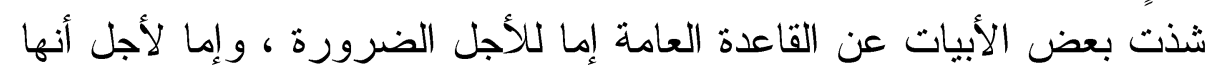

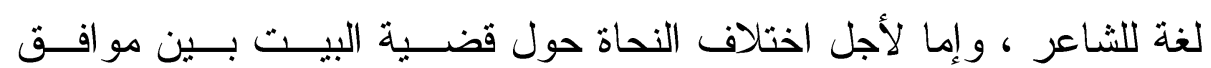
ومعارض،

فمن الأول قول عبدة بن الطبيب:

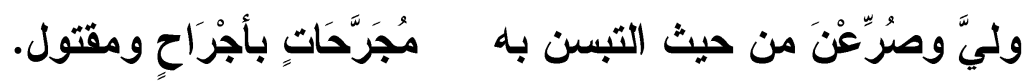

حيث جمع جرح على أجراح لأجل الضرورة ، و القياس : جروح. ومن الثانى قول أبى خراش:

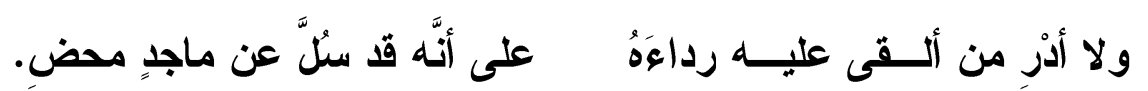

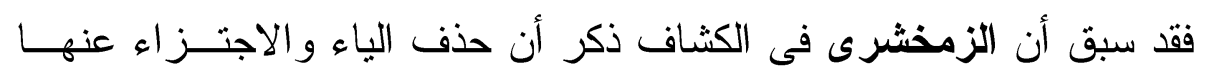

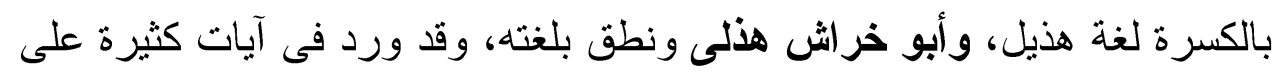

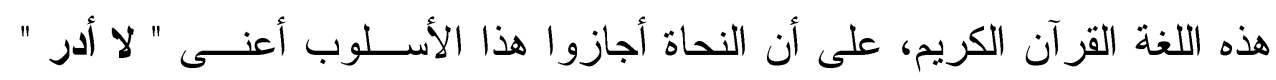
خاصة لكثرة الاستعمال.

ومن الثالث قول عبدة بن الطبيب: 
لمَّا نزلنا نصبنا ظلَّ أرديةٍٍ وفارَ باللَّحمٍ للقومِ المَرَاجيلُ.

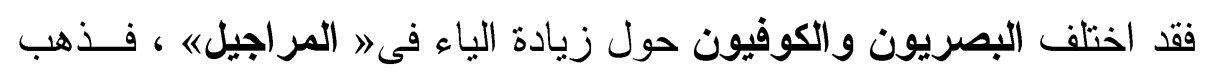

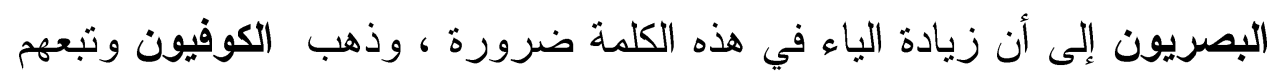

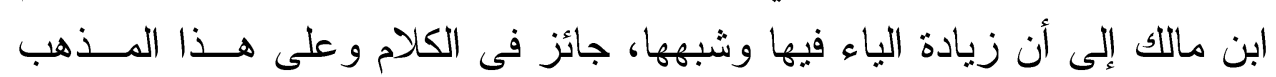

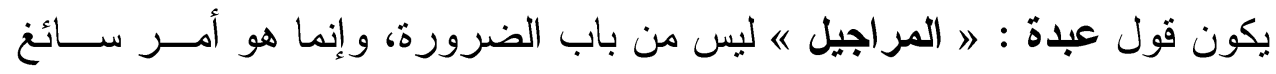

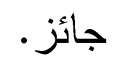

ثالثا : أثبت البحث قدرة ابن مالك - رحمه الله - على التجديد والإضافة لهــا

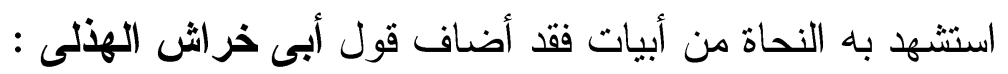

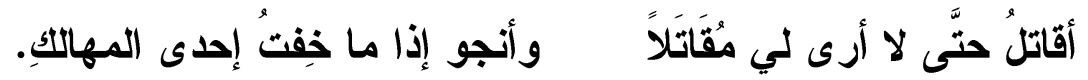
فلم أقف عليه إلا فى شرح عمدة الحافظ وعدة اللافظ له.

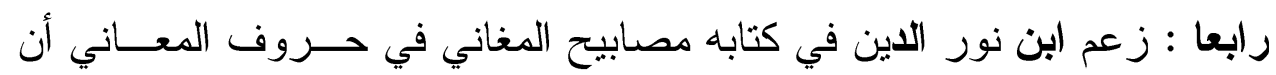

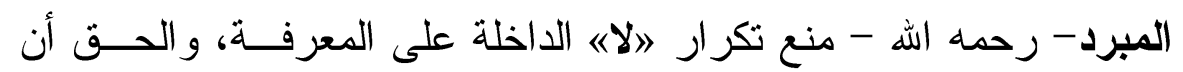

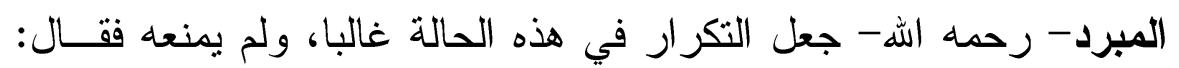

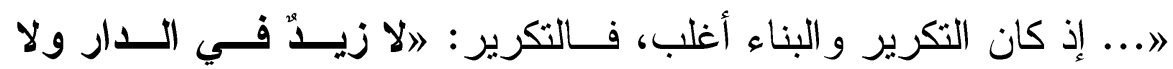
عمرونه. خامسا : هناك بعض استدر اكات على مؤلف كتاب " المعجم المفصل فى شواهد

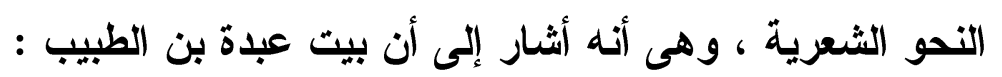

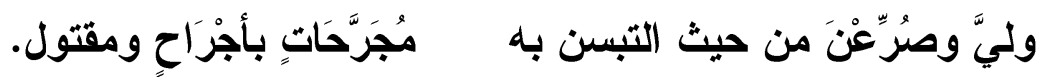

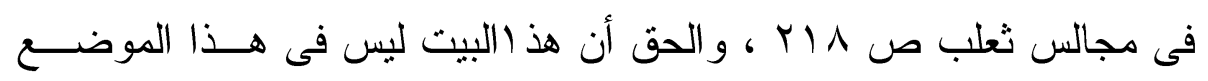

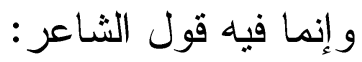

تقول بنتى وقد قربت مرتحلا يا أبت إنك والأنصاب مقتول. وكنلك أثشار إلى أن قول أبى خراش : 
- rYOr.

ألا أيها الطير المربة بالضحى على خالد لقد وقعت على لحم.

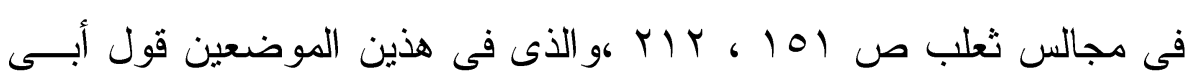

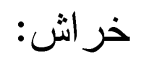

لقد علمت أم الأديبر أننى أقول لها هدِّى ولا تَذْخَرِى لحمى.

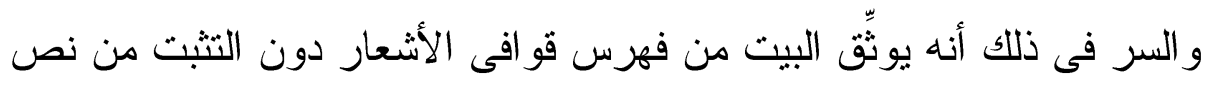

البيت فى موضعه.

هذه أهم النتائج التى توصل إليها البحث .

وصلاً اللهم على سليدا مخمد وعلى آله وصحبه وسلم والخمد الله رب العاطينَ، 


\section{فهرس المصادر والمراجع}

القرآن الكريم

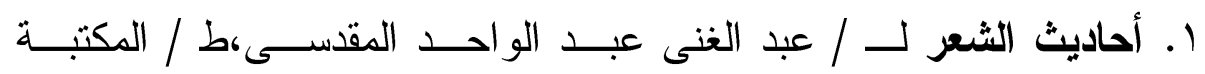

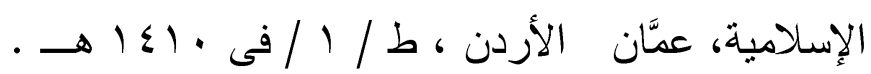

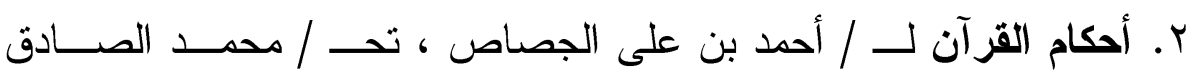

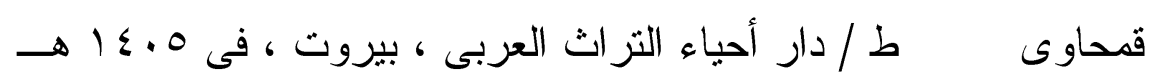

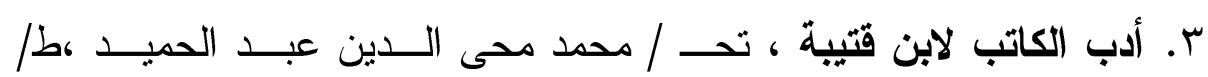

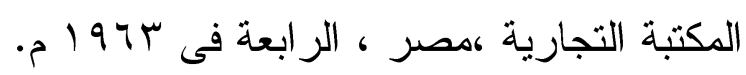

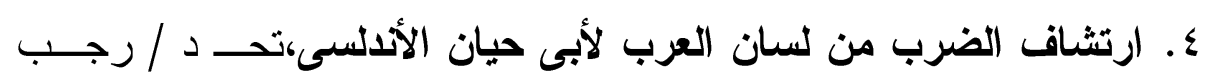

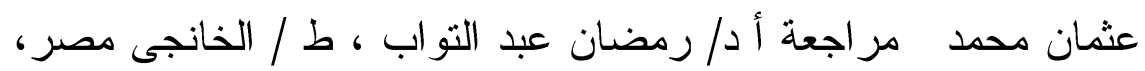

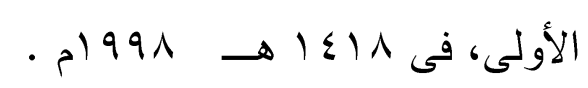

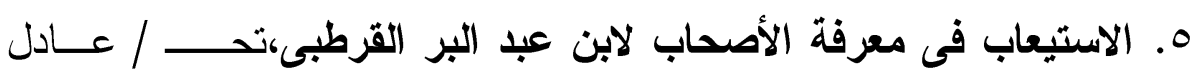

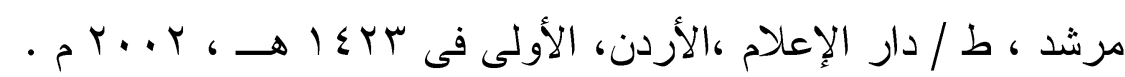

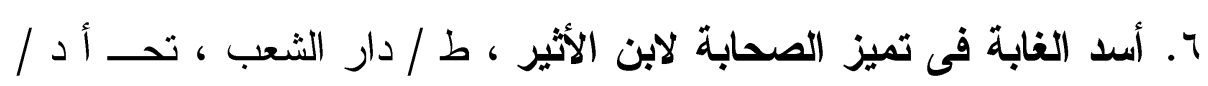

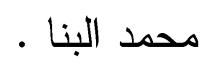

V. أسرار العربية للأنبارى ، تحـــ / محمد حسين شمس الـدين ، ط / دار

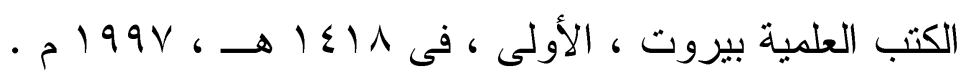

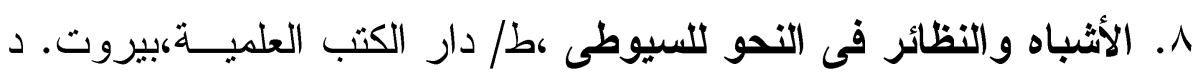

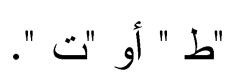

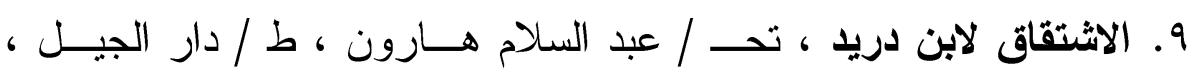

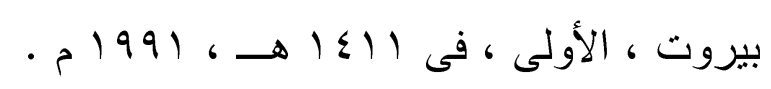


• 1. الإصابة فى تميز الصحابة لابن حجر العسقلانى ، تحـ / عادل

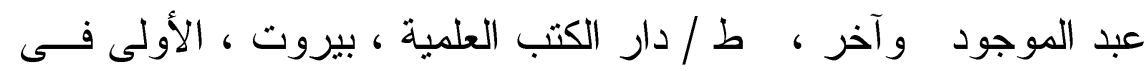

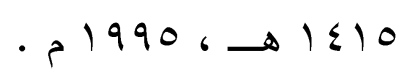

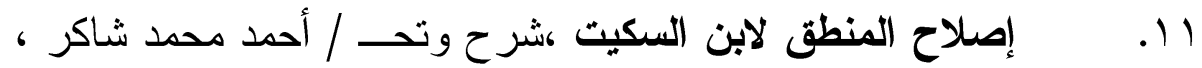

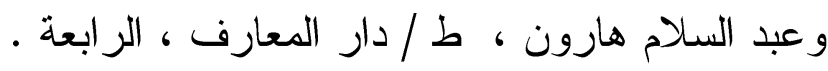

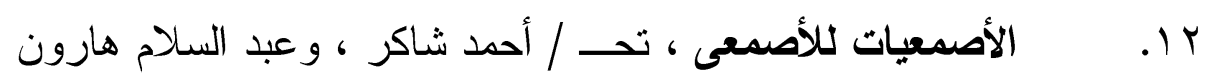
، ك / ب دار المعارف ، الثالثة.

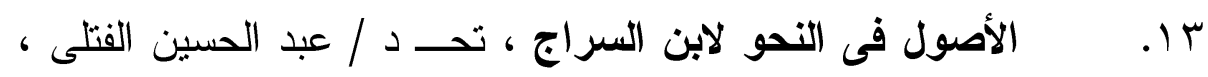

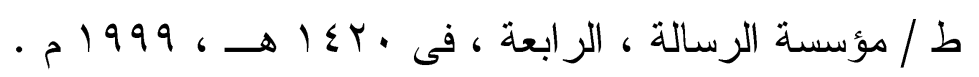

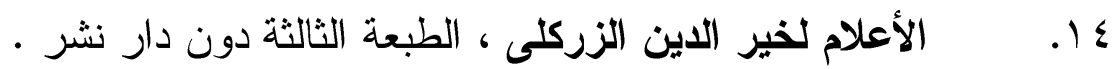

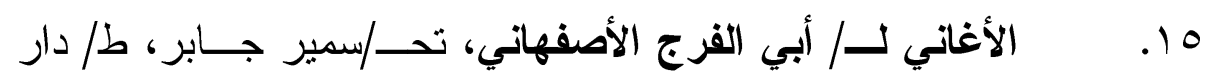
الفكر ، بيروت الثانية.

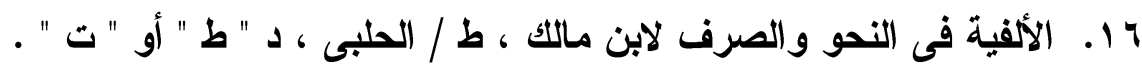

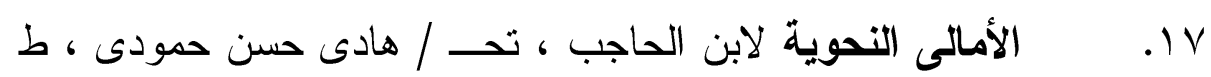

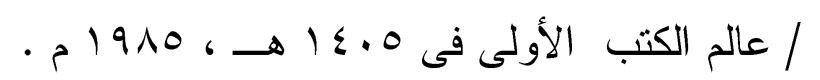

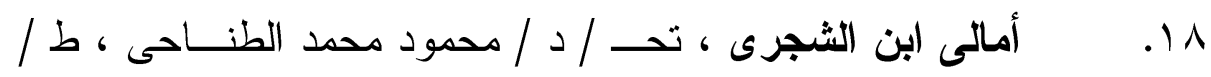

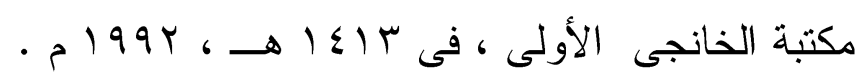

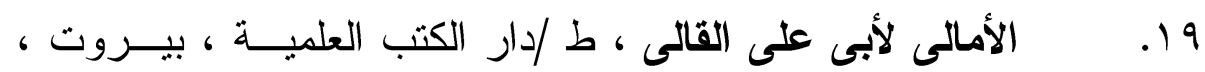
بدون

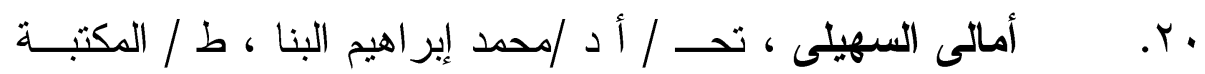
الأزهرية للتزاث مطبعة السعادة.

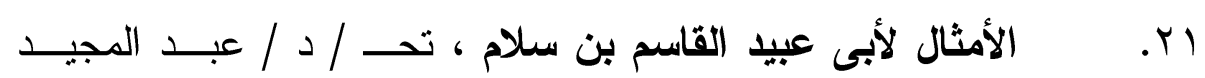

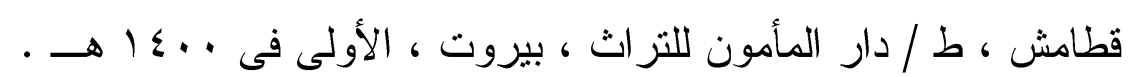


r r. إملاء ما من به الرحمن للعكبرى،طادار الكتب العلمية،الأولى ، فى

rr. الإنصاف فى مسائل الخلاف بين النحويين البصريين و الكوفيين لأبى البركات الأنبارى ، ومعه كتاب : الانتصاف من الإنصاف ، تأليف

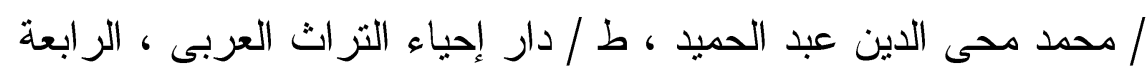

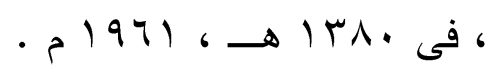

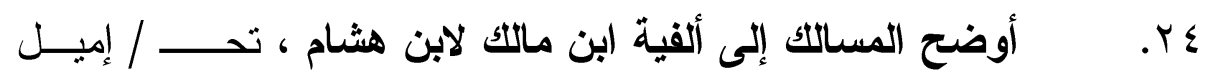

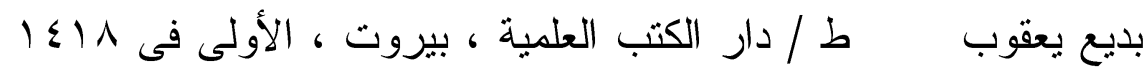
. 1991 ه

OY. إيضاح شواهد الإيضاح للقيسى، تحــ / د / محمد بن محمـود

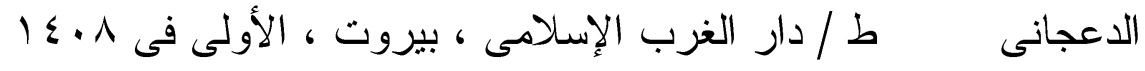
.

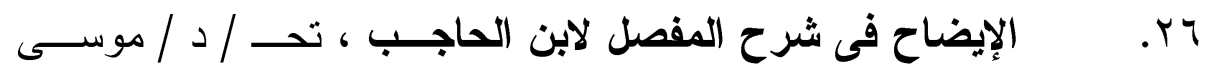

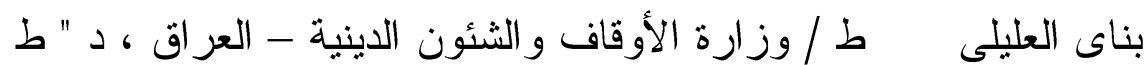

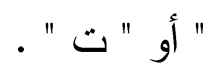

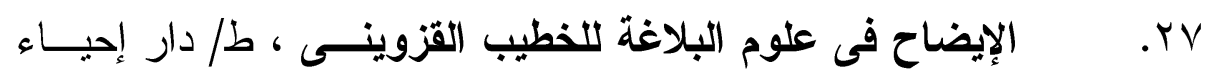

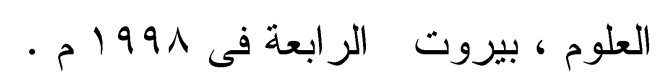

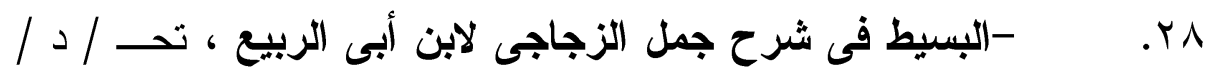

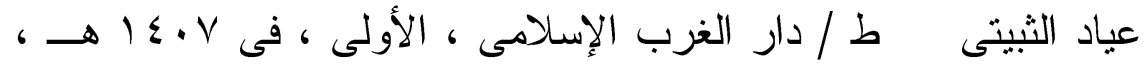
. 1914

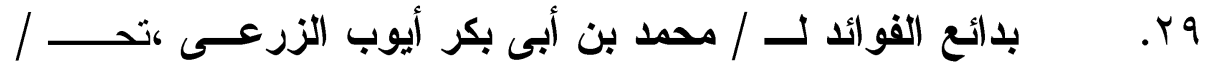

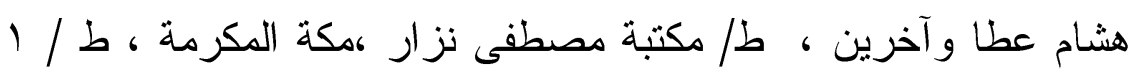
فى اله 


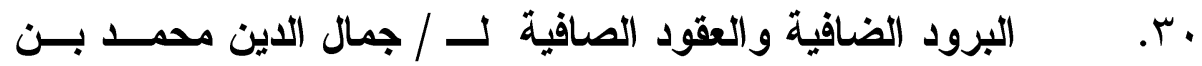

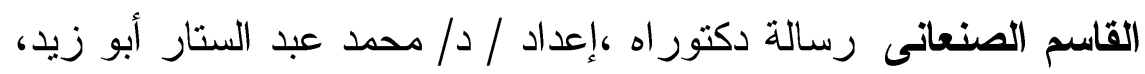

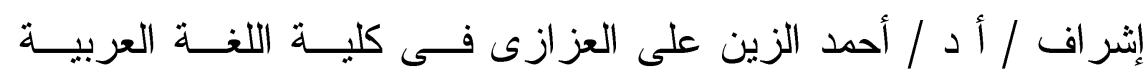

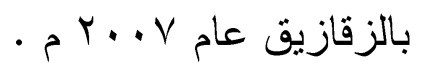

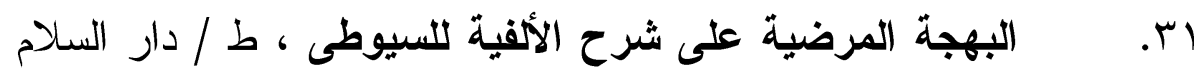

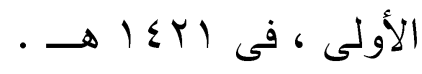

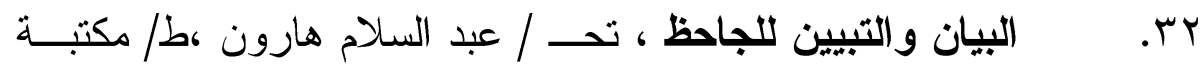

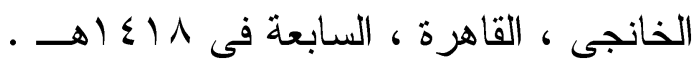

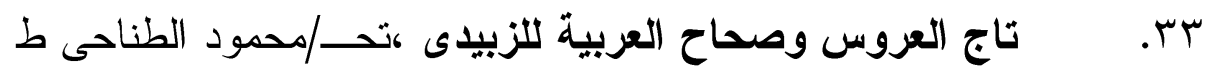

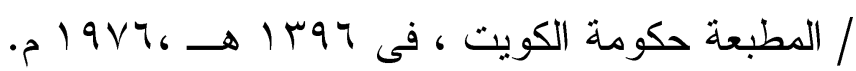

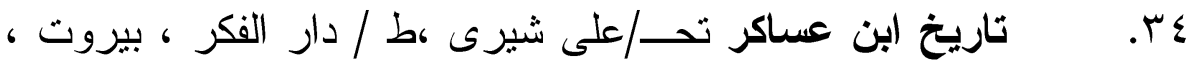

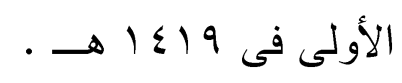

هr. ت تاريخ الإسلام ووفيات المشاهير و الأعلام لــــ/ شــس الــدين

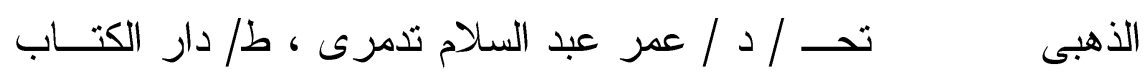

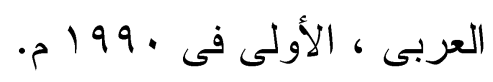

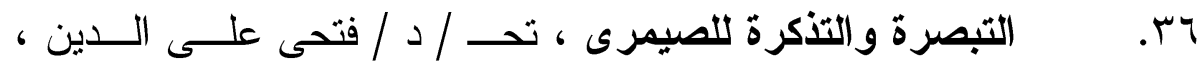

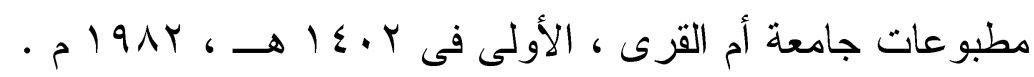

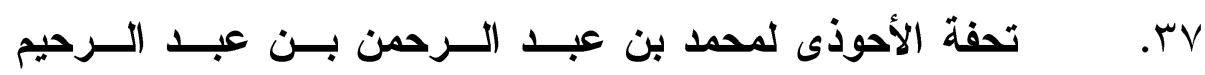

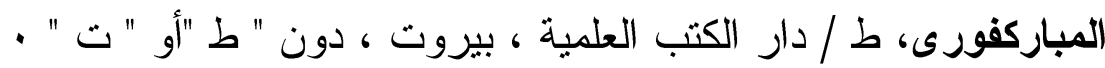

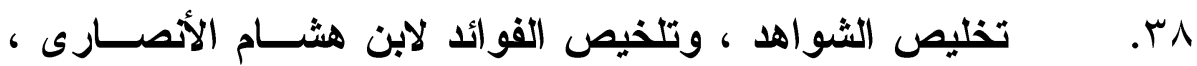

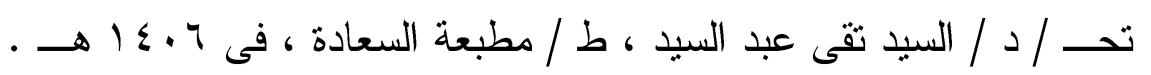

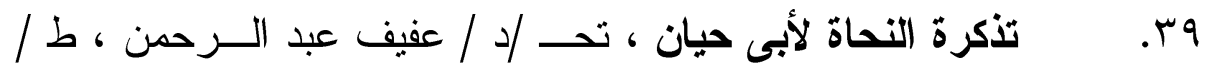

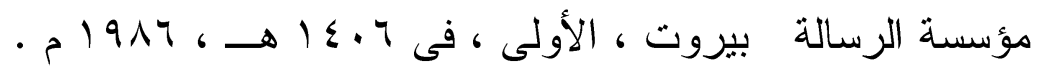


- Y

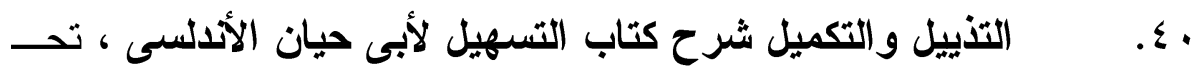

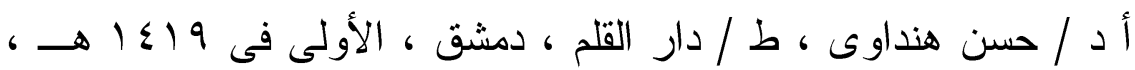

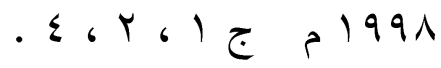

اء. تسهيل الفوائد وتكميل المقاصد لابن مالكك ، تحــــ د / محمــد

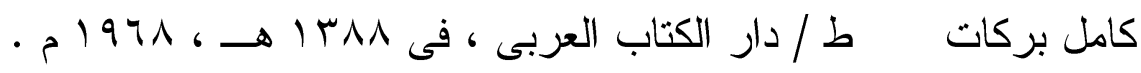

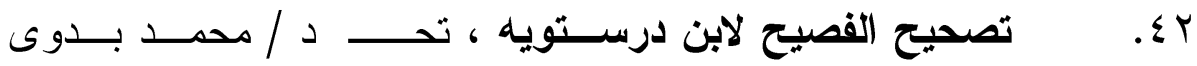

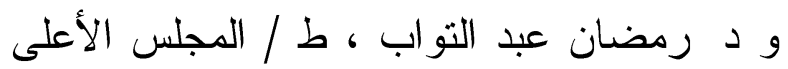

المختون

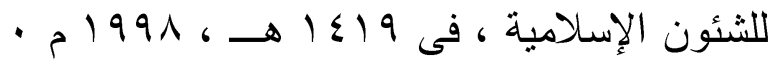

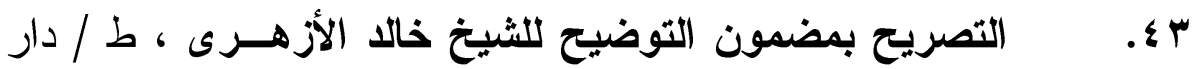

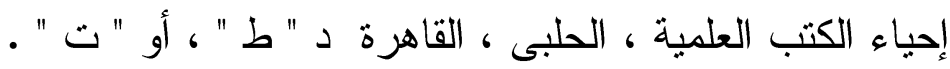

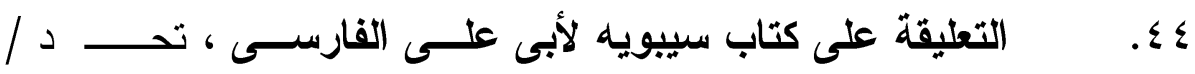

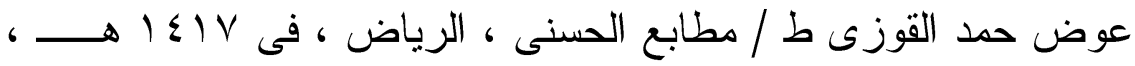

. 1997

0ء. تفسير البحر المحيط لأبى حيان، ط/دار الكتاب الإسلامى،الثانية

فى ساع إهـ.

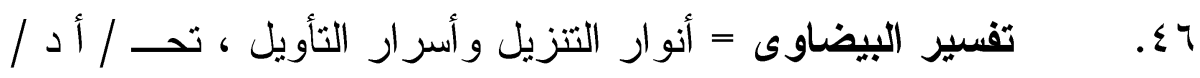

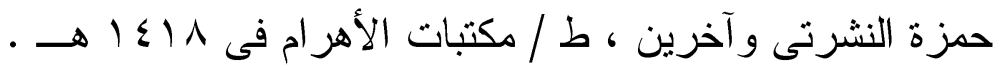

EV

من علم التفسير ط / دار المعرفة ، بيروت د " ط " أو " ت " .

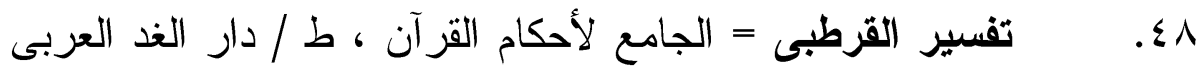

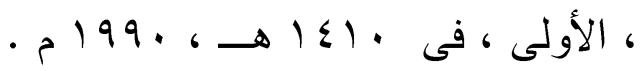

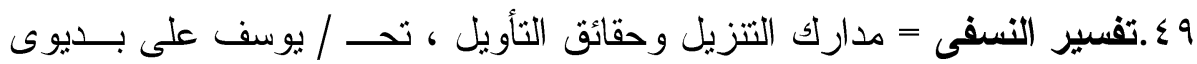

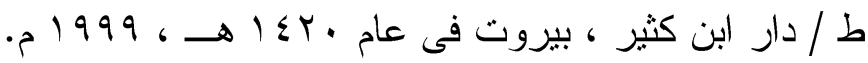




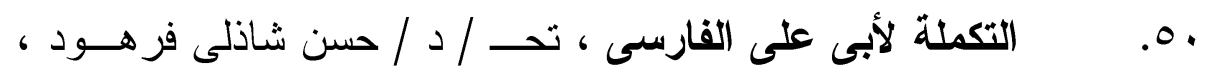

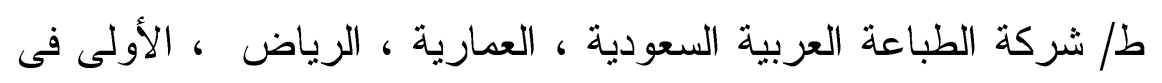

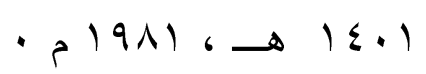

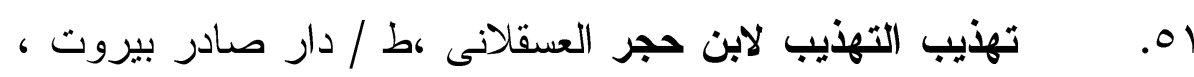

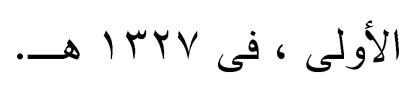

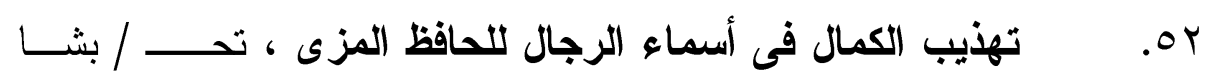

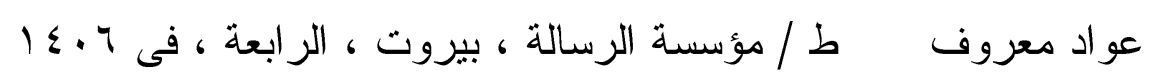
ه 1910 ( 1910

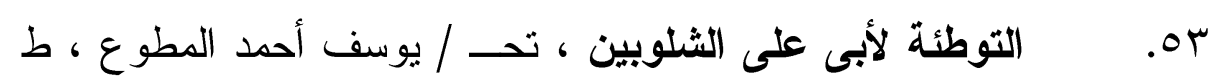

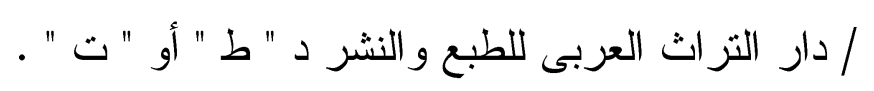

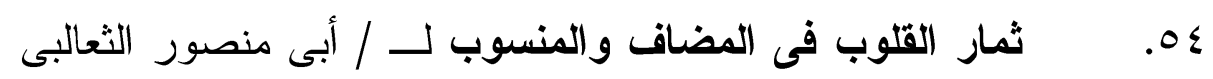

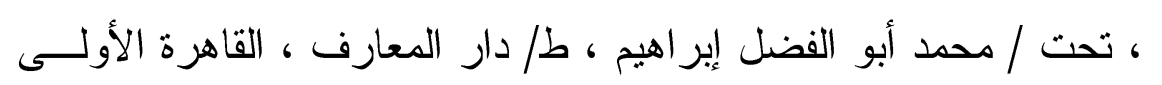
ف فى 1970

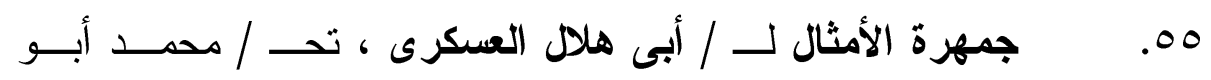

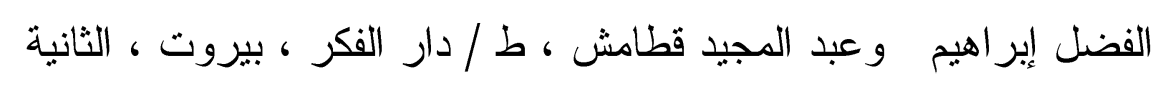

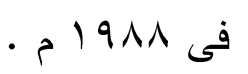

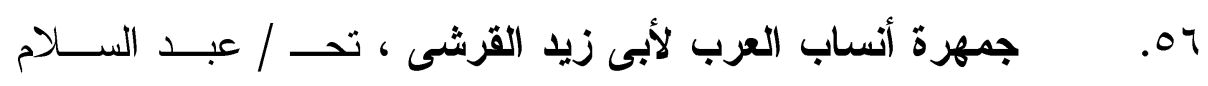

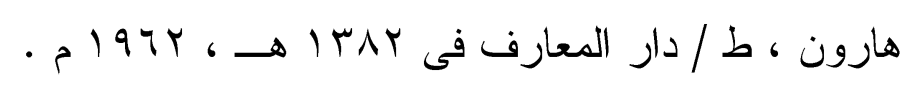

OV

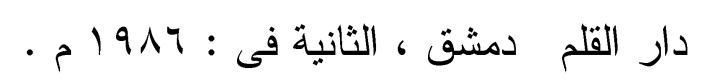

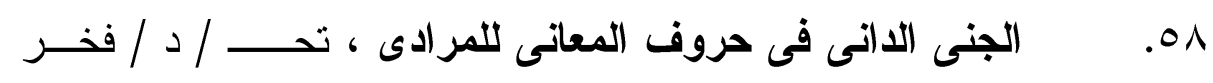

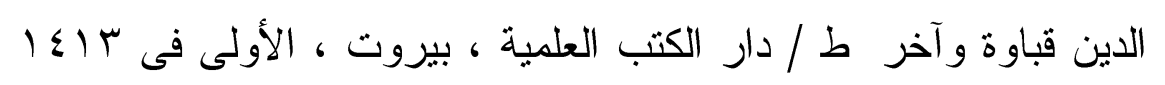
. 


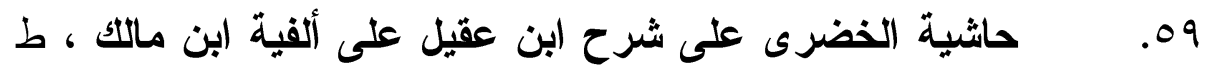

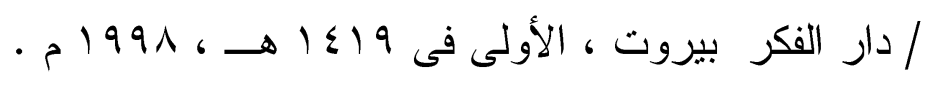

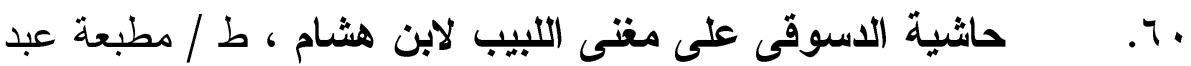

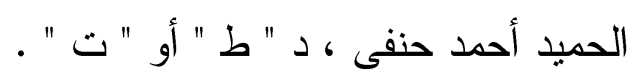

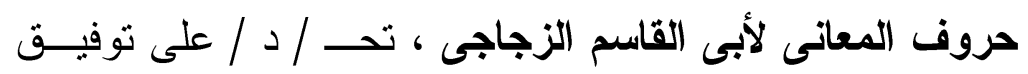

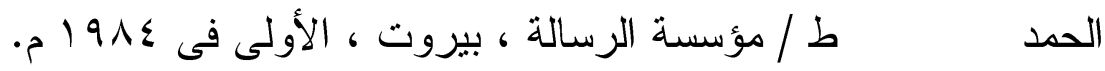

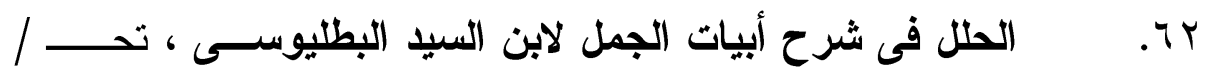

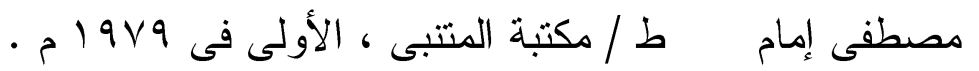

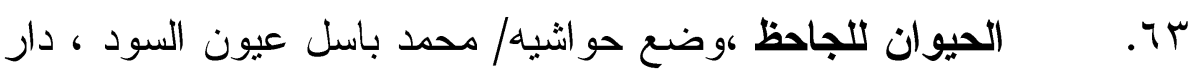

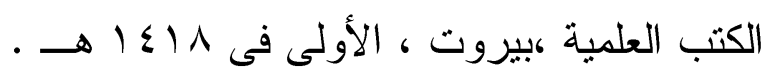

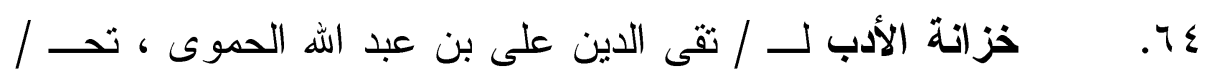

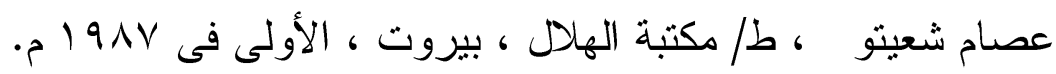

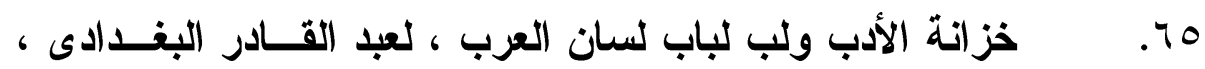

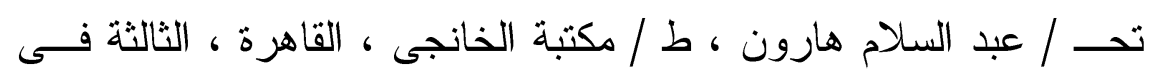

$$
\text { . } 1919 \text { ، } 19.9
$$

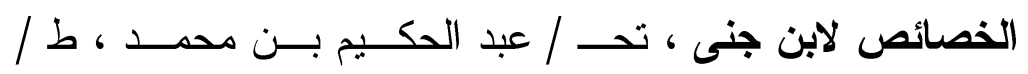

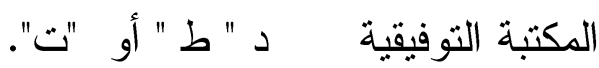

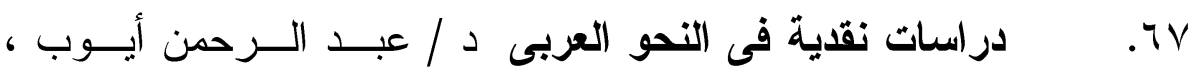

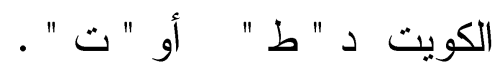

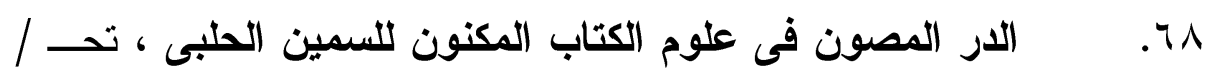

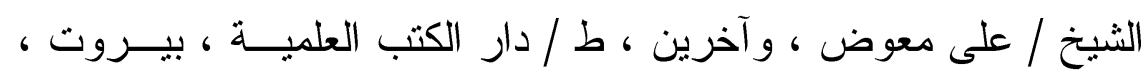

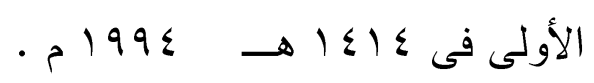


79. الدرر اللوامع على همع الهوامع شرح جمع الجوامع للشنقيطى

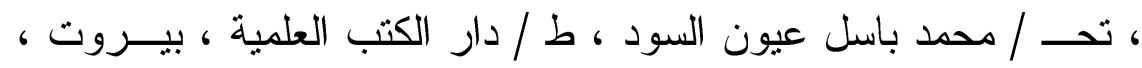

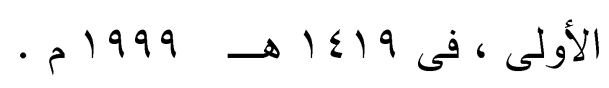

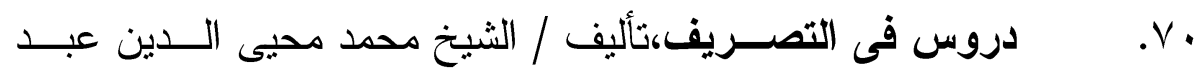

$$
\text { الحميد ، ط / دار الطلائع. }
$$

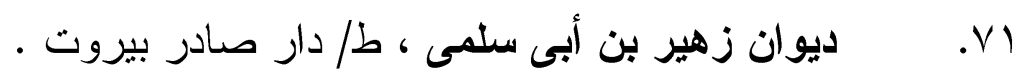

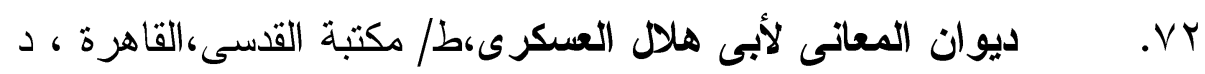

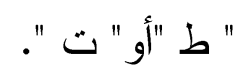

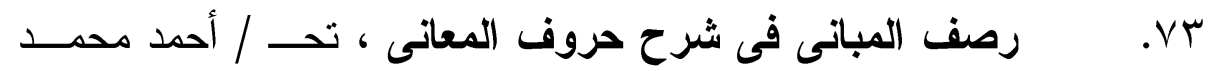

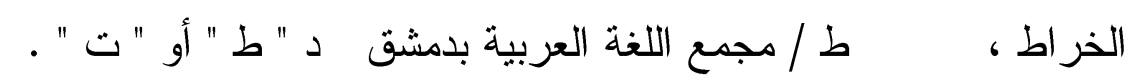

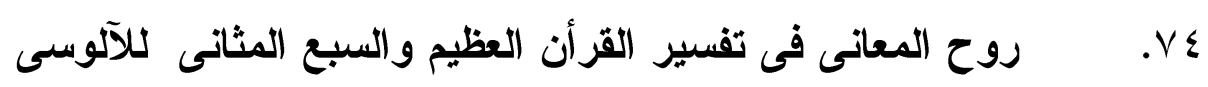

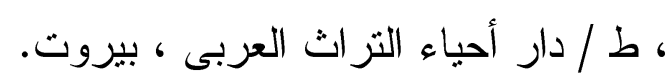

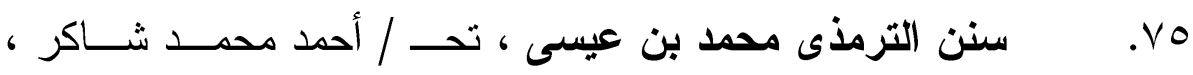

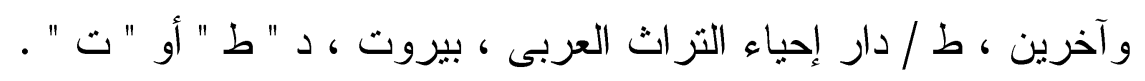

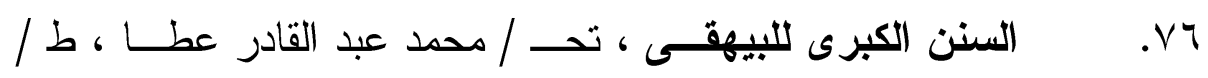

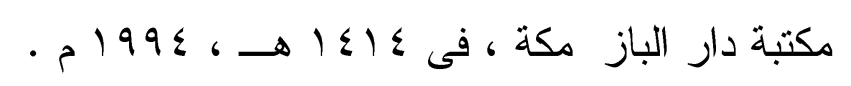

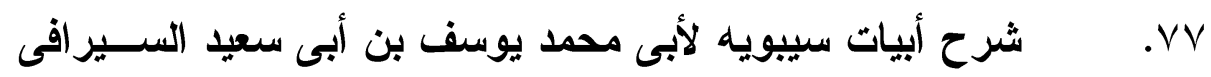

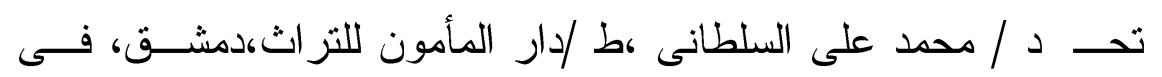

$$
\text { . } 19 \vee 9
$$

ش . VN

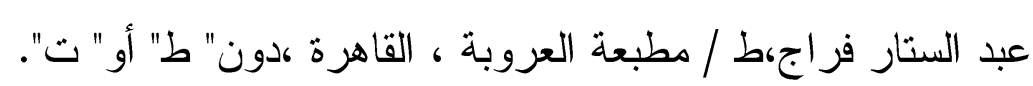

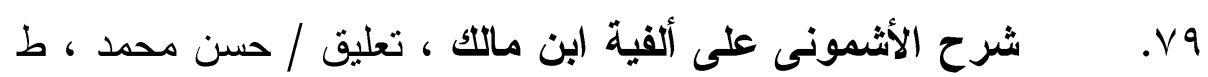

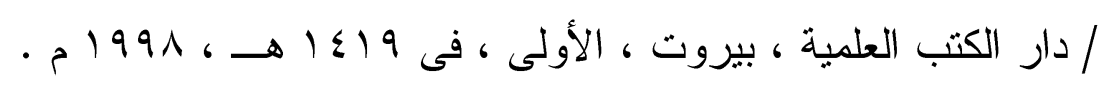




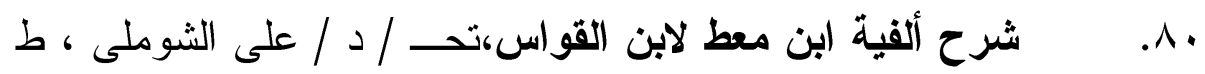

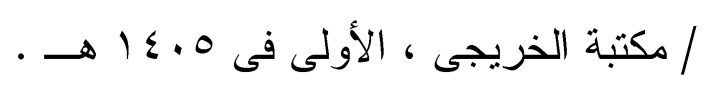

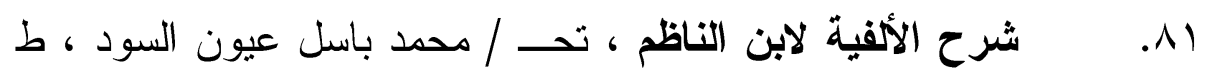

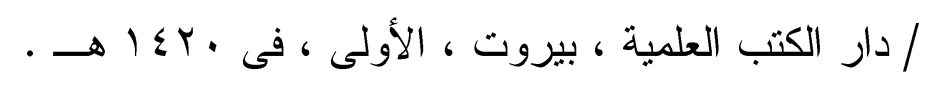

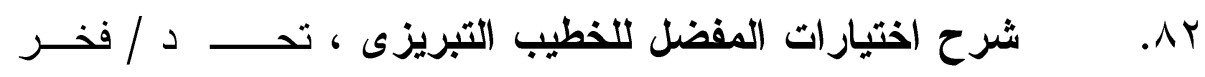

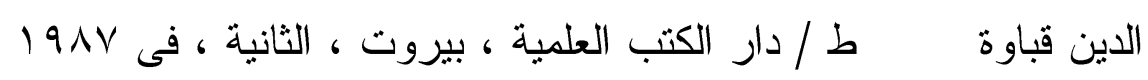

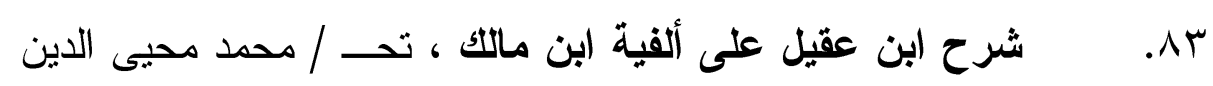

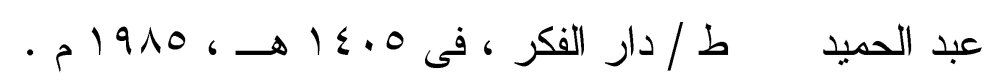

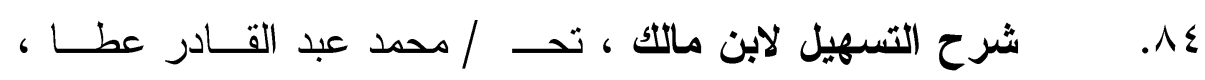

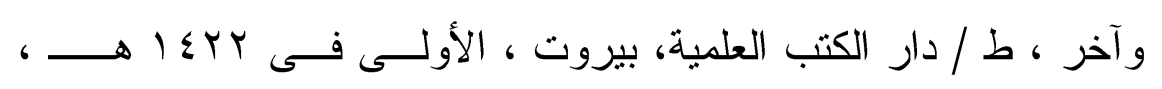
. . r.

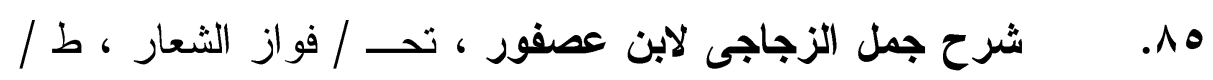

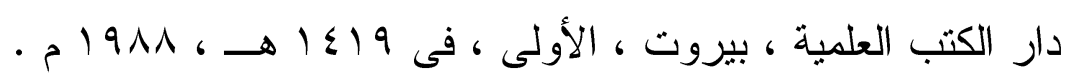

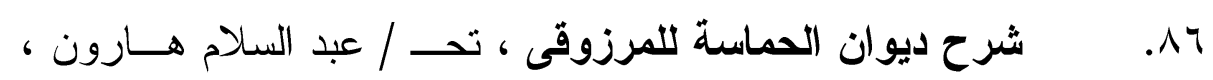

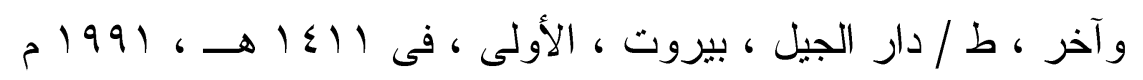

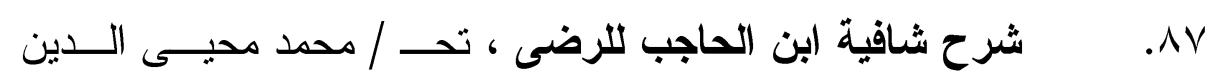

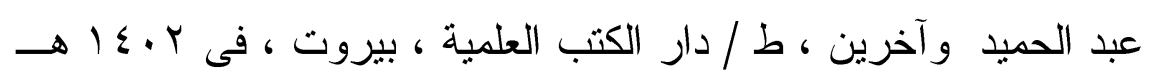

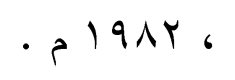

11. شرح شافية ابن الحاجب للنظام ، تأليف : نظام الملـــة والــدين

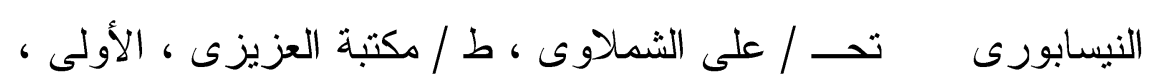
فى النى 
19. شرح شذور الذهب لابن هشام ، تحــ / بركات هبود ، وزميله ،

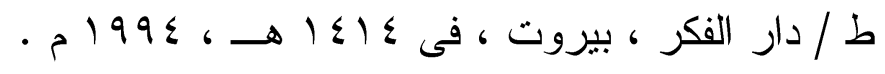

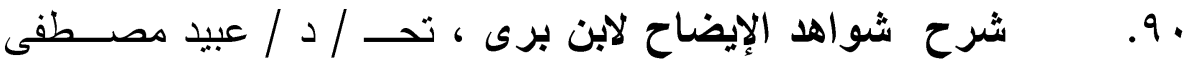

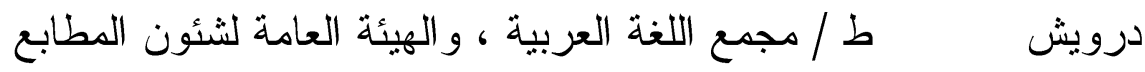

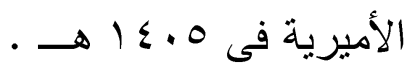

شرح شواهد الثافية للبغــدادى ، تحـ / محمد محيى الدين عبد

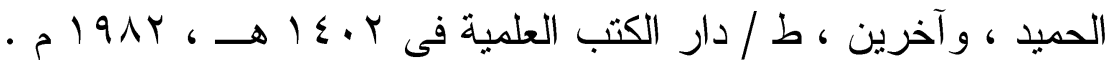

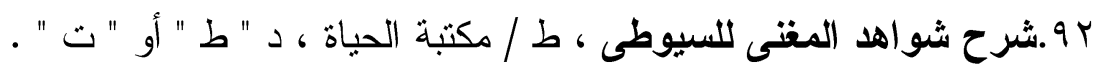

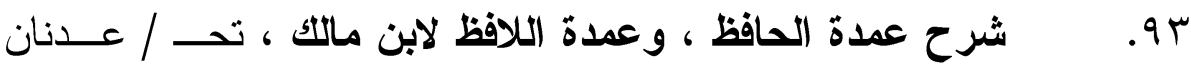

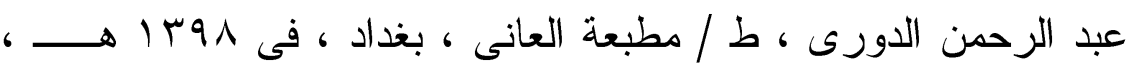
. $19 \vee \wedge$

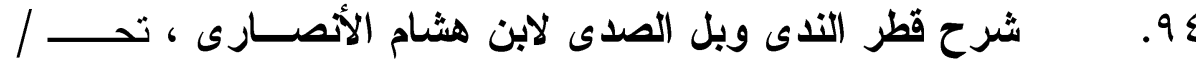

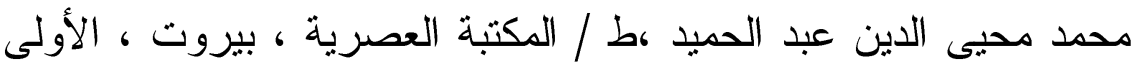

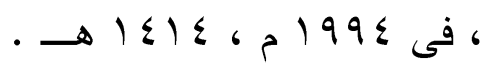

90. شرح الكافية للرضى ، تحس / إميل يعقـوب ، ط / دار الكتبـب

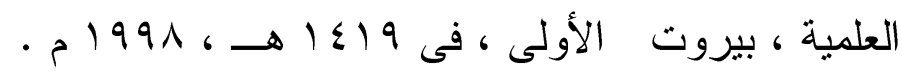

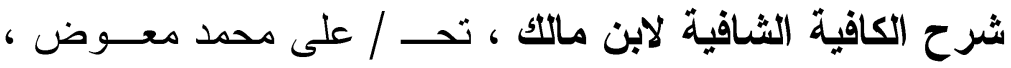

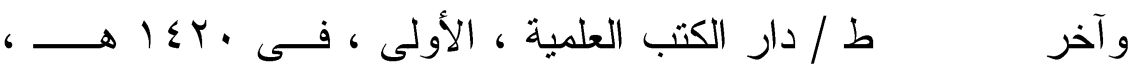

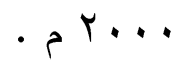

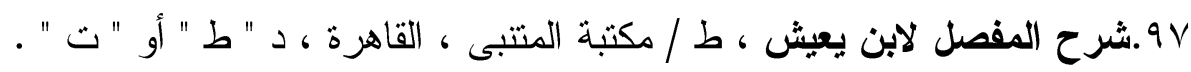

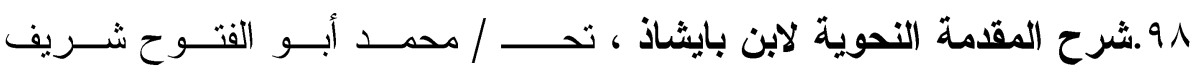

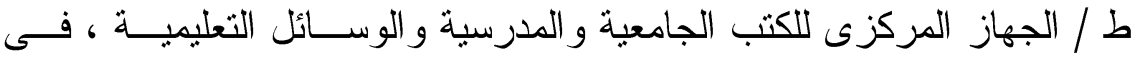


شرح ملحة الإعراب للحريرى ، ط / مطبعة التقدم العلمية بمصر

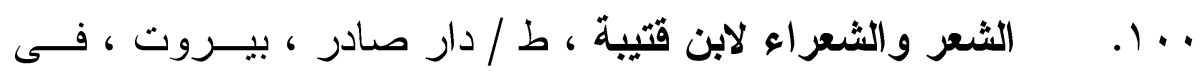

. $19 \cdot r$

1. 1. شعر عبدة بن الطبيب، تحــ / يحى الجبورى،ط/ دار التربيــة ،

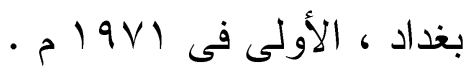

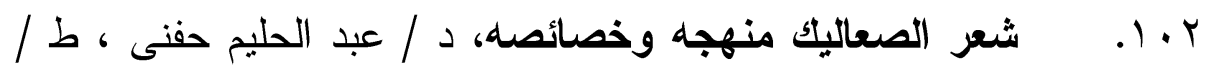
الهيئة المصرية العامة للكتاب ،فى $191 V$ م.

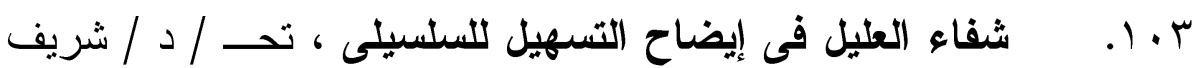

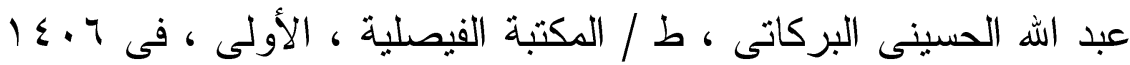
. 1997 ، 199

ـ ـ ا. الصاحبى فى فقه اللغة ومسائلها وسنن العرب فى كلامها لابــن فارس تحــ/أحمد حسن بسج ،ط / دار الكتب العلمية ، بيــروت ،

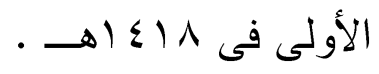

ه. 1. الصحاح " تاج اللغة وصحاح العربية لــ / إسماعيل بن حمــاد

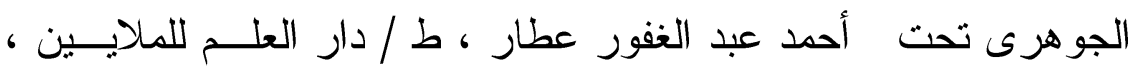

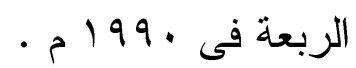

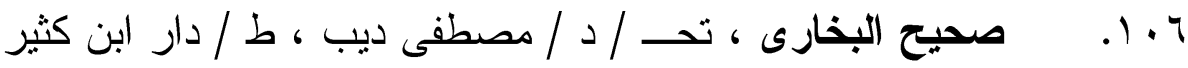

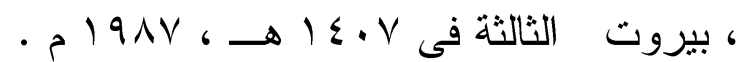

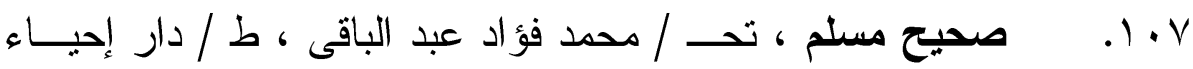

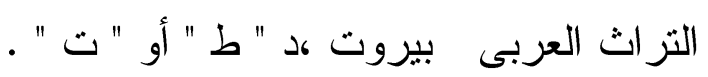

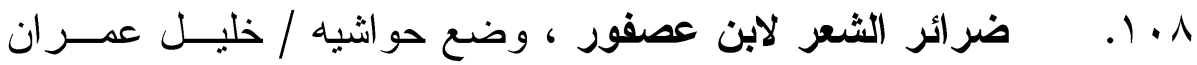

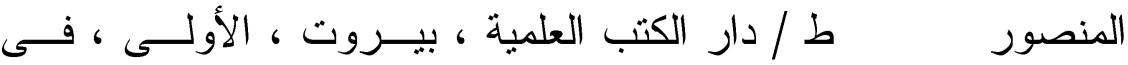

$$
\text { . } 1999 \text { ، } 1 \text { ، } 1 \leqslant \text { r. }
$$


9 • 1. طبقات فحول الثعر اء لابن سلام ، شرحه / محمود محمد شاكر

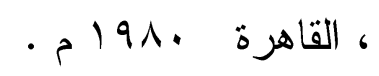

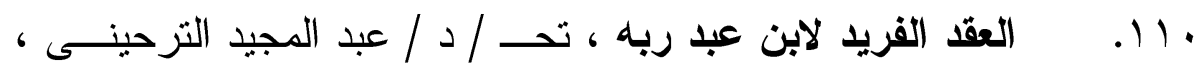

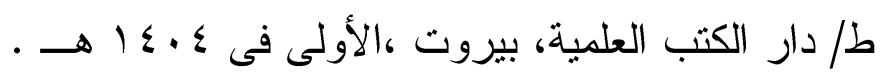

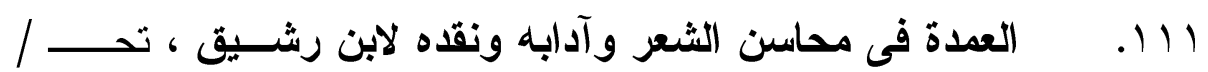

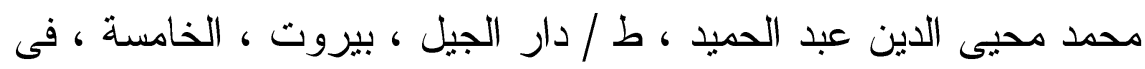

$$
\text { . } 1911 \text { ، } 1918.1
$$

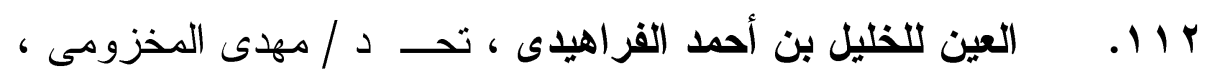

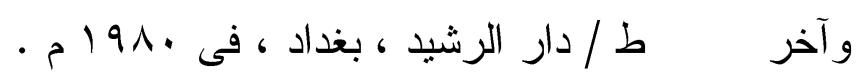

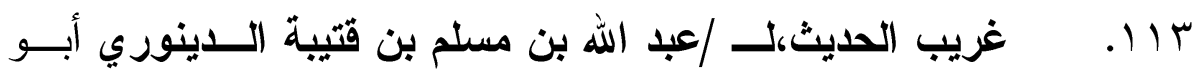

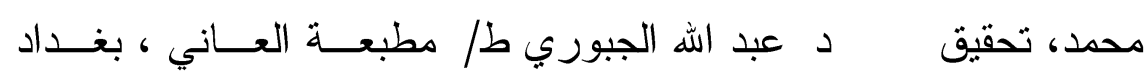

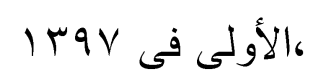

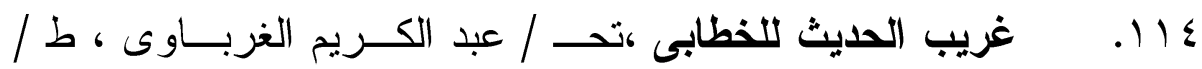

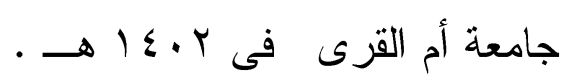

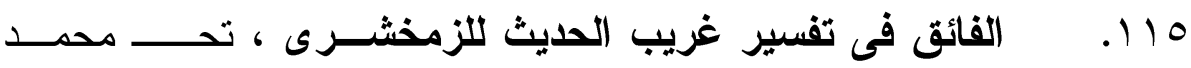

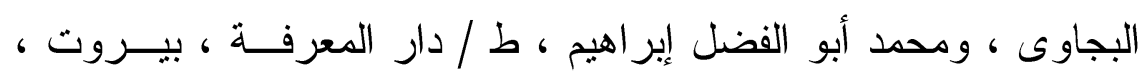
الثانية .

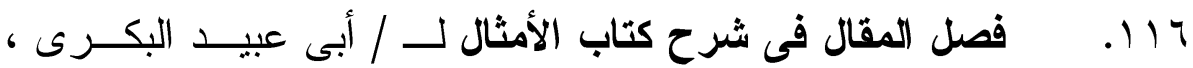

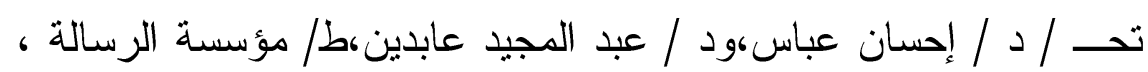

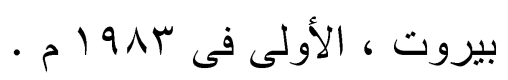

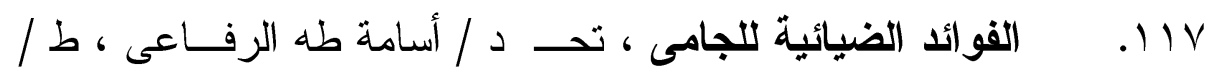

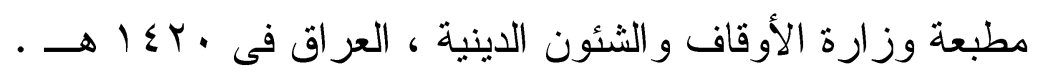


111. القاموس المحيط للفيروزآبادى ، ط / دار الجيل ، بيروت ، د " ط " أو " ت " .

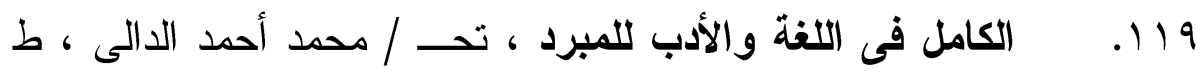

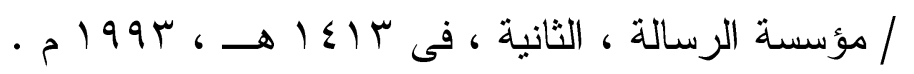

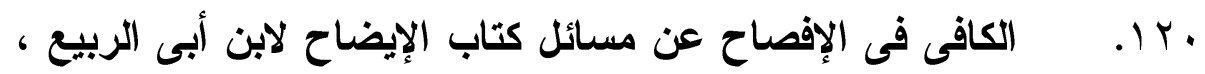

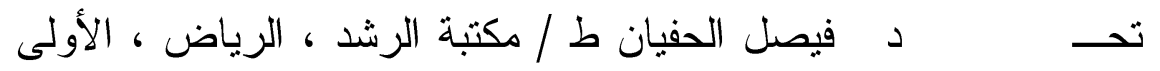
فى سارا

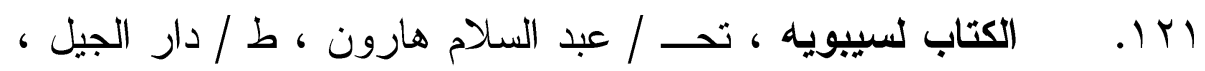

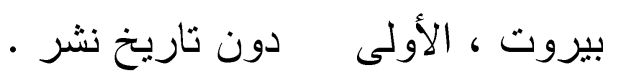

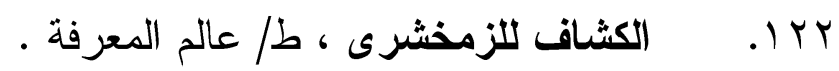

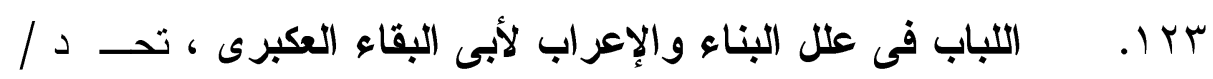

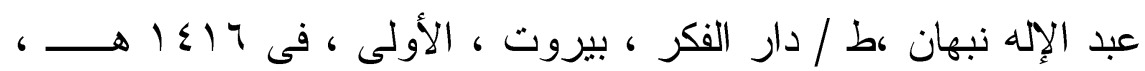
. 1990

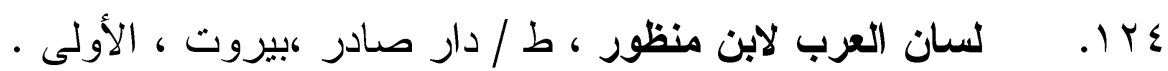

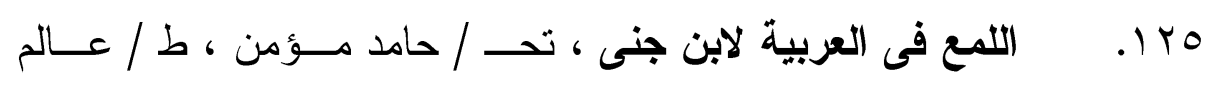

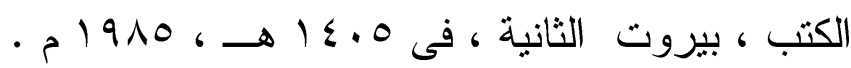

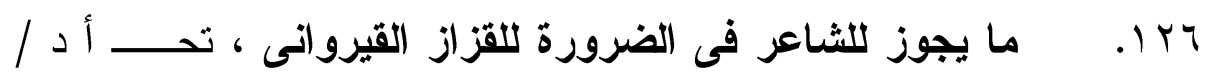

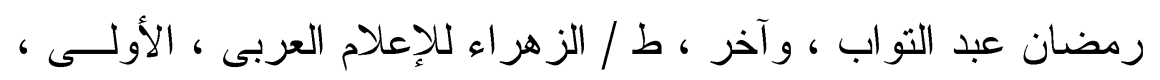

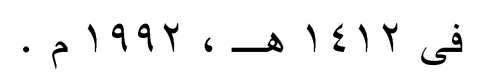
IYV

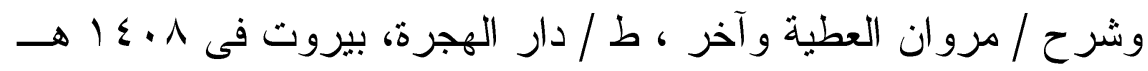




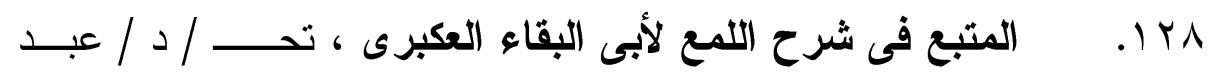

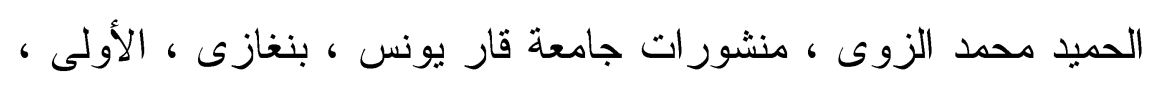

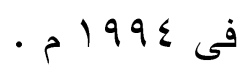

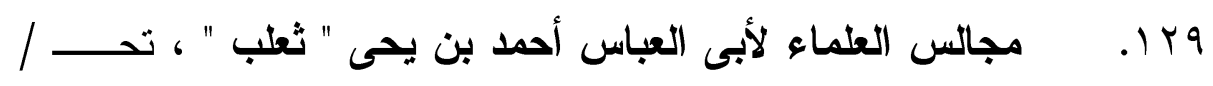
عبد السلام هارون ، ط / دار المعارف ، الخامسة .

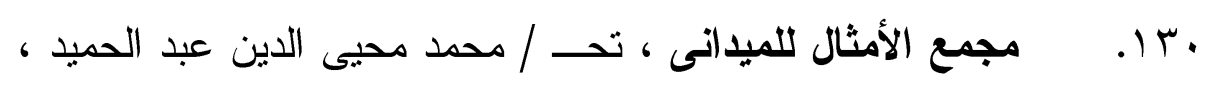

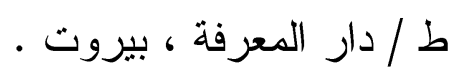

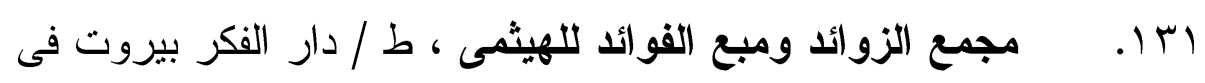

$$
\rightarrow 1 \leqslant 14
$$

بT ا. المحتسب فى تبيين وجوه شواذ القراعات ، والإيضاح عنها لابن

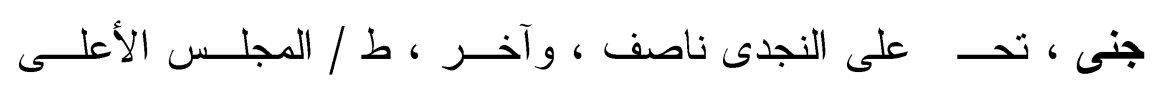

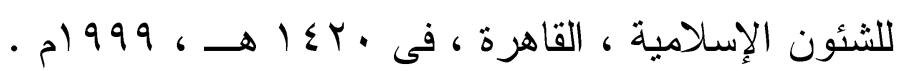

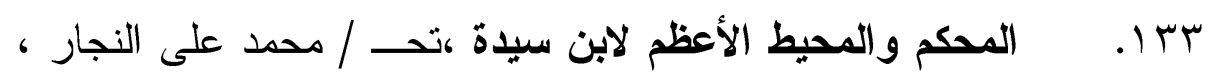

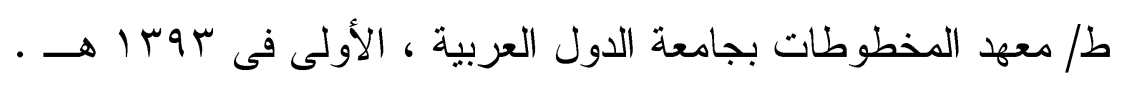

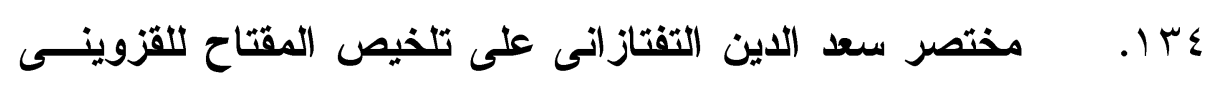

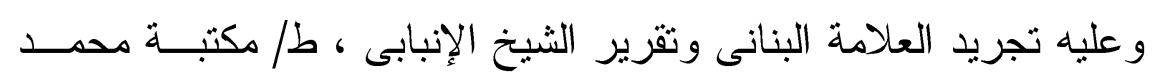

$$
\text { على صبيح القاهرة ، الأولى فى }
$$

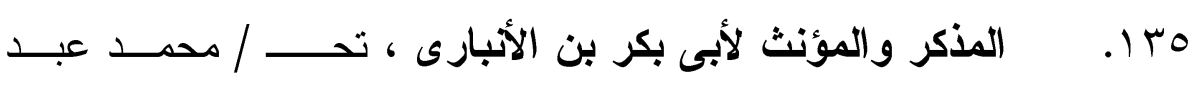

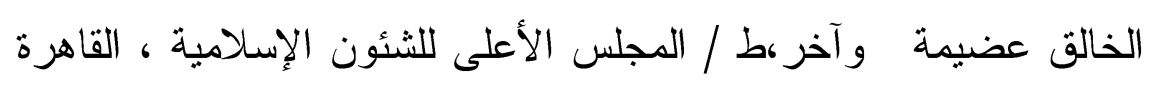

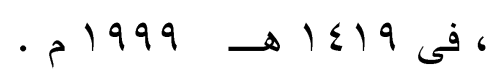

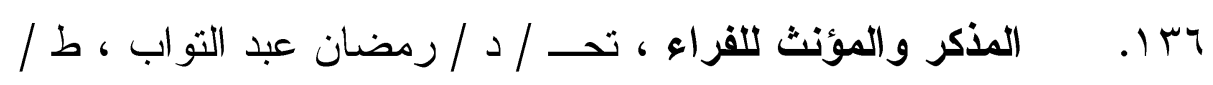

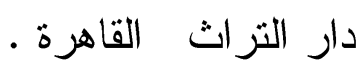




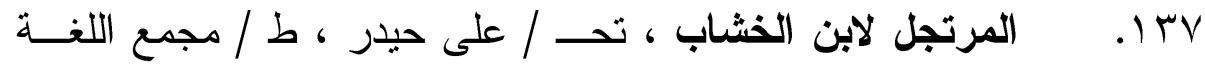

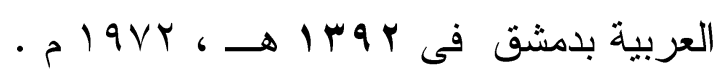

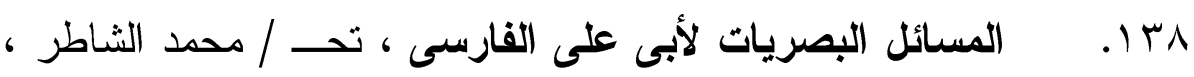

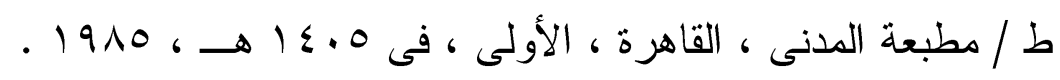

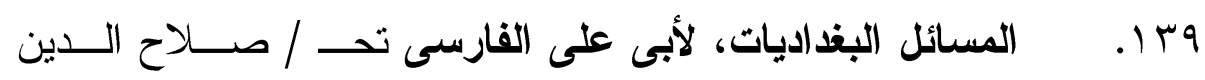

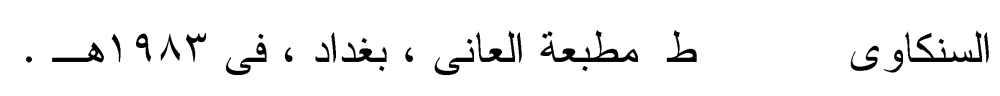

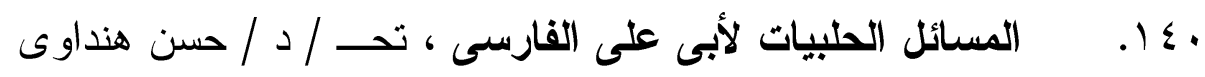

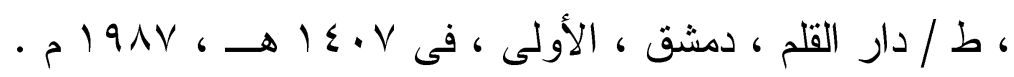

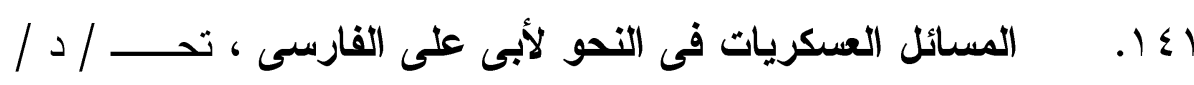

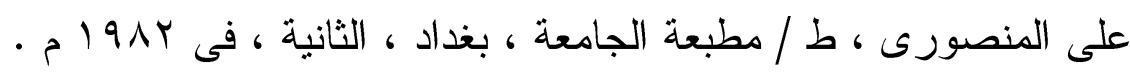

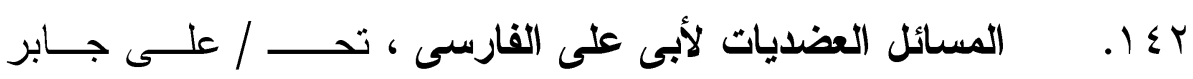

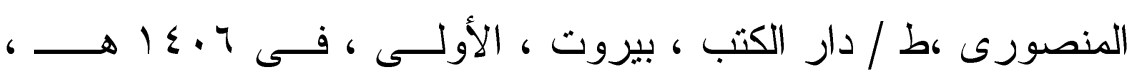

- 1914

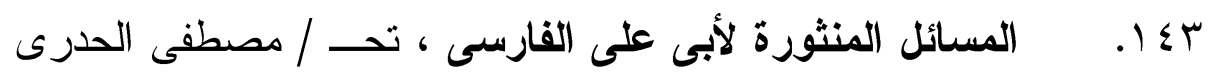

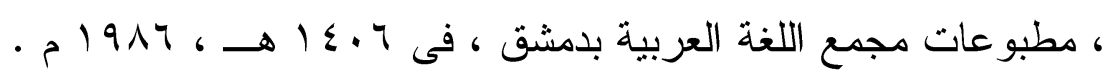

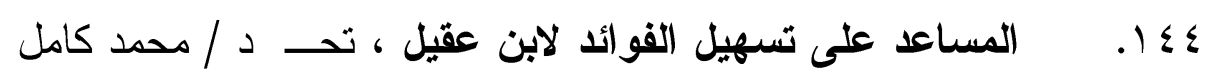

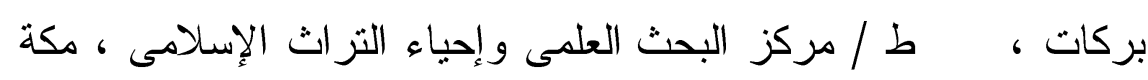

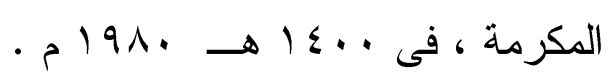

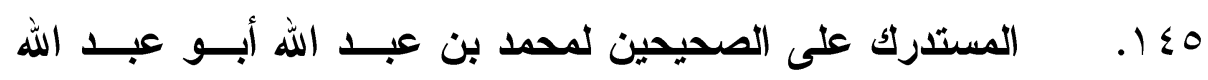

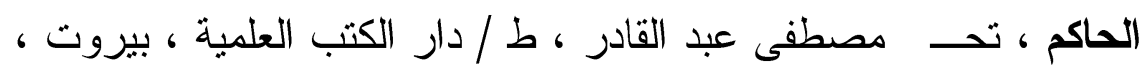

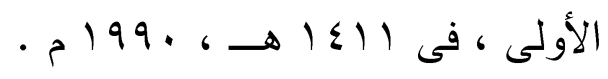

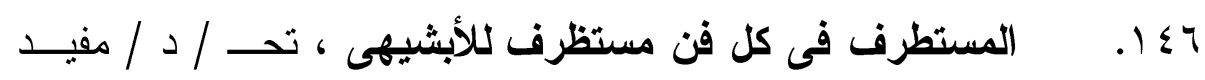

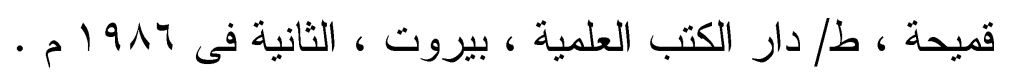


\&V

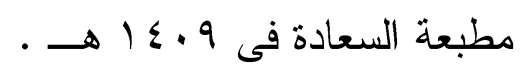

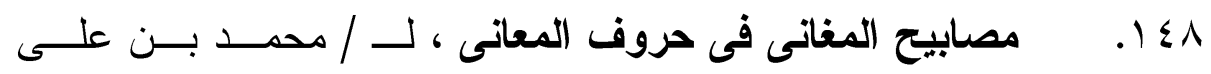

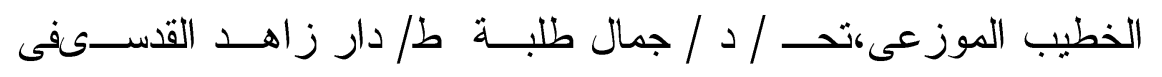

$$
\rightarrow 1 \leqslant 10
$$

9 1 . معانى الحروف للرمانى، تحـ / د / عبد الفتاح شلبى ، ط / دار

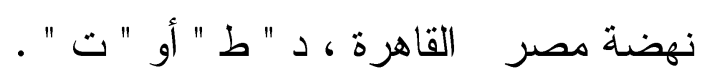

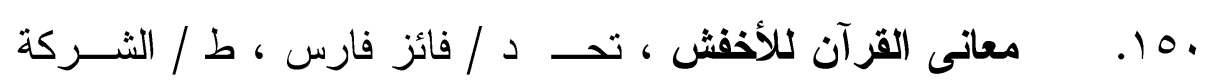

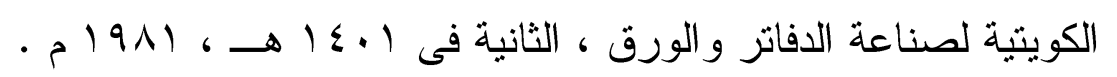

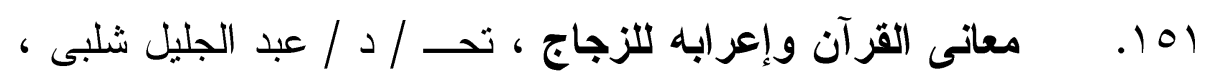

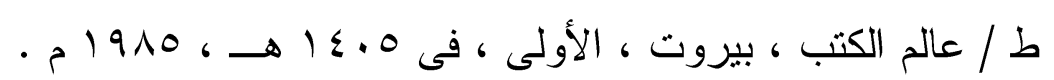

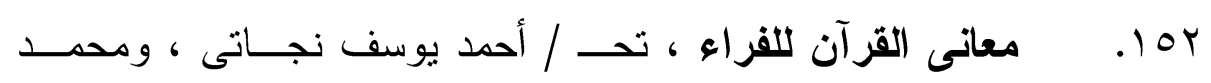

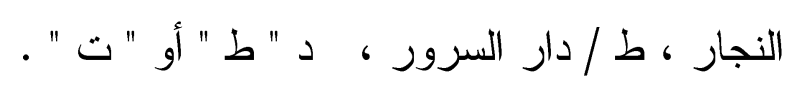

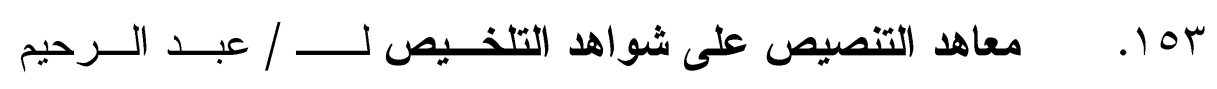

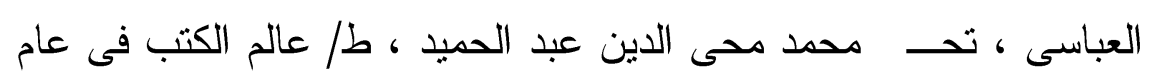
- $19 \leqslant V$

ع 1. معجم الأدباء لياقوت الحمـوى ، ط / دار المــأمون للتــراث ،

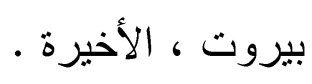

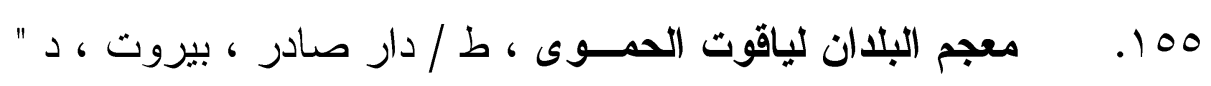

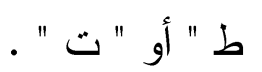

107. المغنى فى تصريف الأفعال، تــأليف / د / محمــد عبــدالخالق

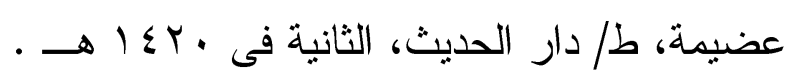




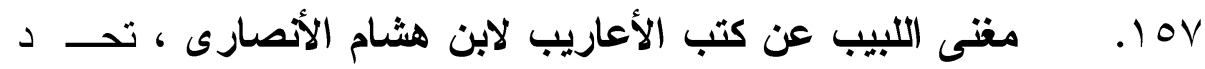

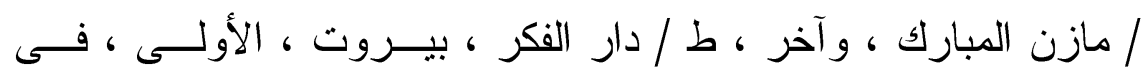

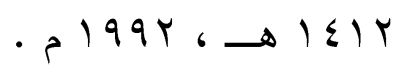

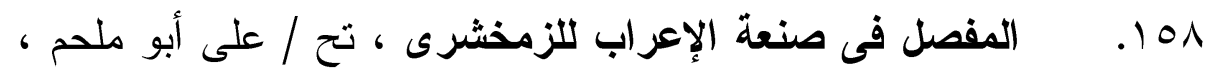

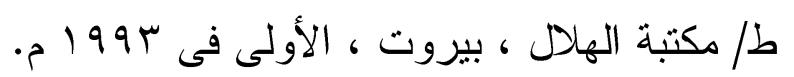

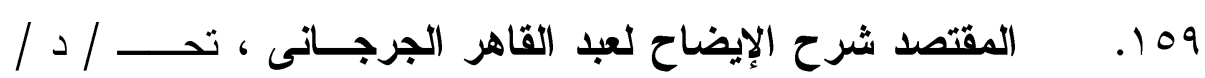

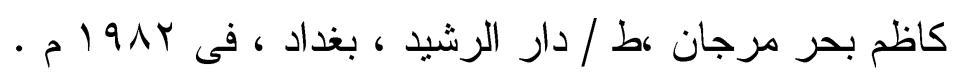

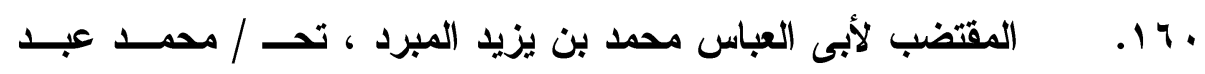

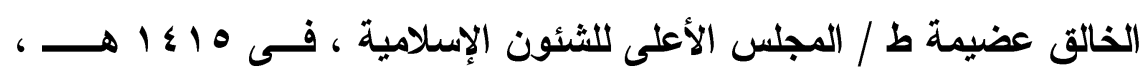
.

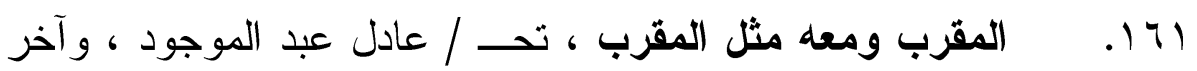

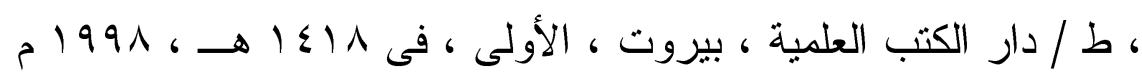

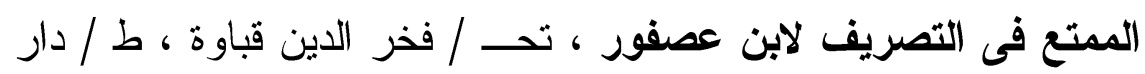

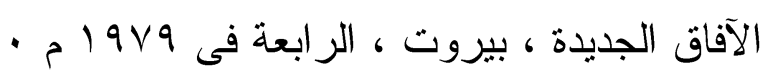

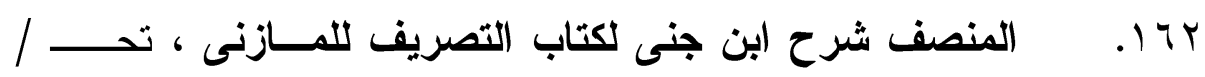

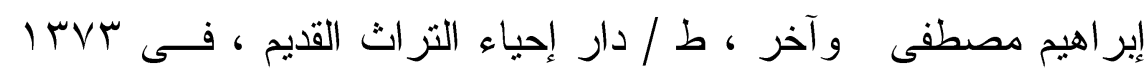
ه إئه ،

با7 ا. المنصف من الكلام على مغنى ابن هشام للشمنى ، وبهامشــها

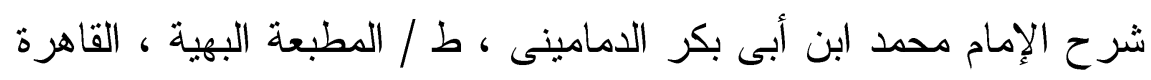

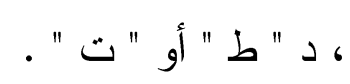

ع ا1. النكت فى تفسير كتاب سيبويه ، وتبيين الخفى من لفظه وغريبه

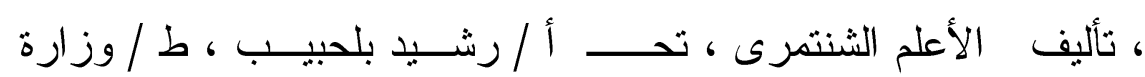

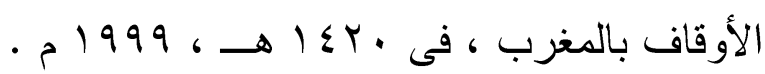




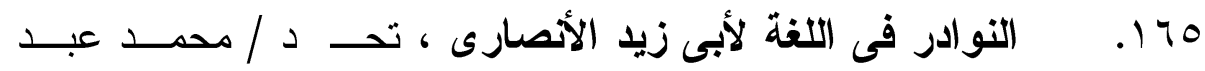

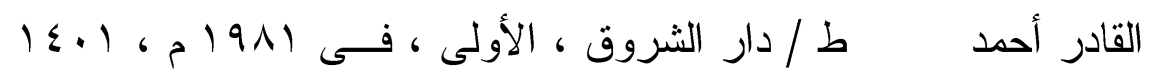

$$
\rightarrow
$$

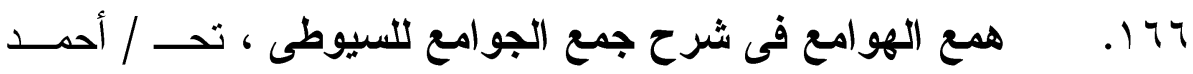

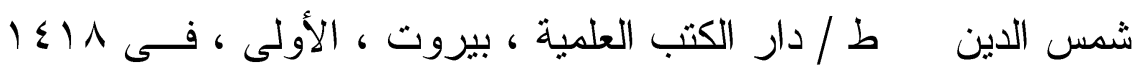

$$
\text { ه }
$$

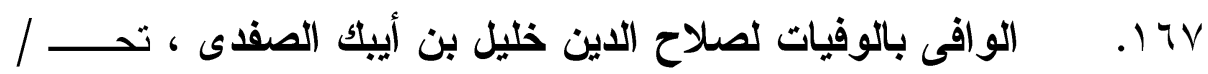

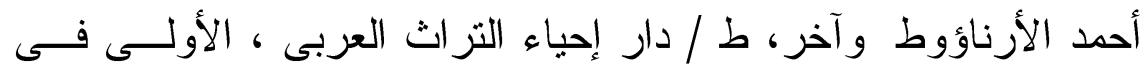

$$
\text { . } r \text {.... }
$$

